\title{
GEOGRAFIA, TERRITÓRIO E SOCIEDADE NA AMAZÔNIA
}

Ricardo Gilson da Costa Silva Francilene Sales da Conceição

Organizadores
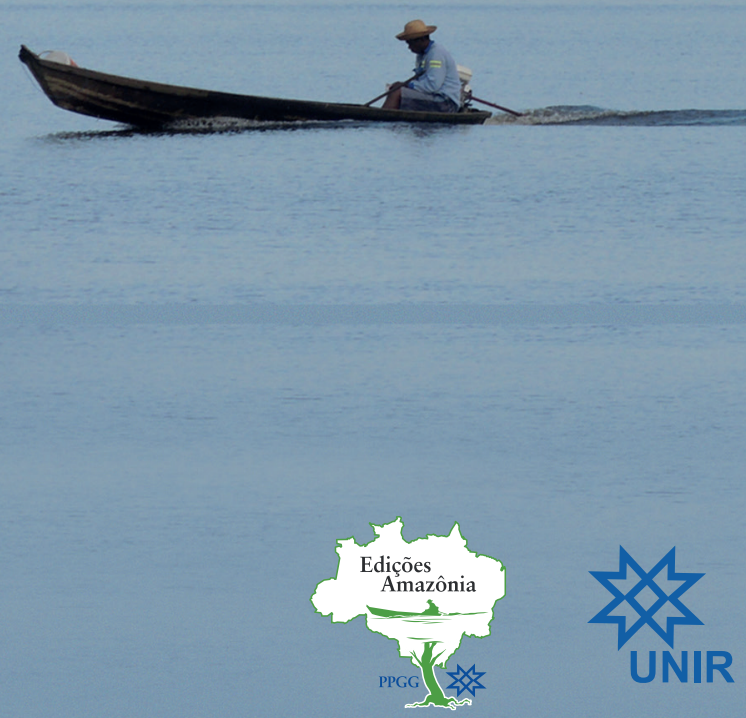


\title{
Ricardo Gilson da Costa Silva Francilene Sales da Conceição
}

\author{
Organizadores
}

\section{Geografia, Território e Sociedade na Amazônia}
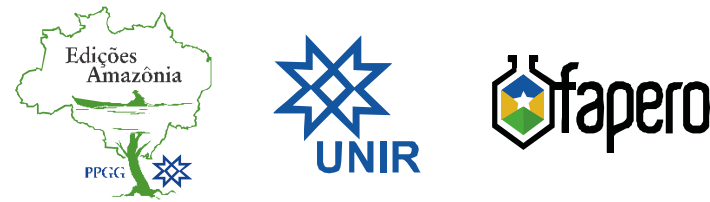


\section{UNIVERSIDADE FEDERAL DE RONDÔNIA - UNIR}

Reitora: Profa. Dra. Marcele Regina Nogueira Pereira

Vice-Reitor: Prof. Dr. José Juliano Cedaro

\section{NÚCLEO DE CIÊNCIAS EXATAS E DA TERRA - NCET}

Diretor: Prof. Dr. Ariel Adorno de Sousa

Vice-Diretor: Prof. Dr. Marinaldo Felipe da Silva

\section{PROGRAMA DE PÓS-GRADUAÇÃO MESTRADO E DOUTORADO EM GEOGRAFIA - PPGG}

Coordenador: Prof. Dr. Ricardo Gilson da Costa Silva

Vice-Coordenador: Prof. Dr. João Paulo Assis Gobo

\section{EDIÇÕES AMAZÔNIA PPGG - CONSELHO EDITORIAL}

Prof. Dr. Adnilson de Almeida Silva - UNIR, Porto Velho, Brasil

Prof. Dr. Dorisvalder Dias Nunes - UNIR, Porto Velho, Brasil

Profa. Msc. Francilene Sales da Conceição - UEA, Manaus, Brasil

Prof. Dr. Isaque dos Santos Sousa - UEA, Manaus, Brasil

Prof. Dr. Josué da Costa Silva - UNIR, Porto Velho, Brasil

Prof. Dr. João Paulo Assis Gobo - UNIR, Porto Velho, Brasil

Profa. Dra. Luciana Riça Mourão Borges - UNIR, Guajará-Mirim, Brasil

Profa. Dra. Maria Madalena de Aguiar Cavalcante - UNIR, Porto Velho, Brasil

Profa. Dra. Maria das Graças Silva Nascimento Silva - UNIR, Porto Velho, Brasil

Profa. Dra. Mariana Arzeno - UBA, Buenos Aires, Argentina

Prof. Dr. Márcio Douglas Amaral - UFPA, Belém, Brasil

Prof. Dr. Nilson Cesar Fraga, UEL, Londrina, Brasil

Prof. Dr. Ricardo Gilson da Costa Silva - UNIR, Porto Velho, Brasil

Profa. Dra. Rosa Ester Rossini - USP, São Paulo, Brasil

Prof. Dr. Silvio Simone da Silva - UFAC, Rio Branco, Brasil

Profa. Dra. Viviane Vidal da Silva - UFAM, Humaitá, Brasil

Prof. Dr. Hervé Théry - CNRS, Paris, França 
(C) by Ricardo Gilson da Costa Silva e Francilene Sales da Conceição

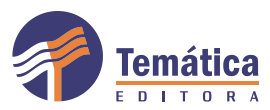

Rua Prudente de Moraes, 2421 Centro

Porto Velho-RO

(69) 9.9246-7839

info@tematicaeditora.com.br

Comissão Técnica

Abel Sidney

Preparação de originais e revisão

Rogério Mota

Editoração eletrônica e capa

Foto da capa: Ricardo Gilson da Costa Silva

Livro publicado com recurso da Fapero conforme Programa de apoio à Pesquisa - PAP- chamada FAPERO n. 04/2018, Processo n. 012427596201890.054/2018.

DOI: $10.5935 / 978-65-87350-34-9$

\section{Dados Internacionais de Catalogação na Publicação (CIP)}

G345 Geografia, território e sociedade na Amazônia / Organizadores : Ricardo Gilson da Costa Silva, Francilene Sales da Conceição. - Porto Velho : Temática Editora e PPGG/UNIR, 2021.

$26.087 \mathrm{~KB}$

ISBN 978-65-87350-34-9

1. Geografia crítica. I. Silva, Ricardo Gilson da Costa, org. II. Conceição, Francilene Sales da, org. III. Programa de Pós-graduação Mestrado e Doutorado em Geografia - PPGG da Universidade Federal de Rondônia - UNIR. IV. Título.

CDD 918.11

CDU 911.3(811)

Ficha catalográfica elaborada pela Bibliotecária Zane S. S. Santos CRB 11/1081 


\section{Licença Creative Commons

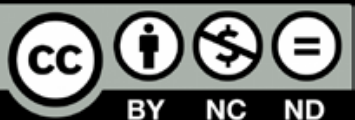

Esta obra é de acesso aberto. É permitida a reprodução parcial ou total desta obra, desde que citada a fonte e a autoria e respeitando a Licença Creative Commons indicada. É proibido qualquer uso para fins comerciais.

O conteúdo desta obra, conceitos e opiniões, inclusive sua revisão, é de responsabilidade de seus autores, os quais também se responsabilizam pelas imagens utilizadas.
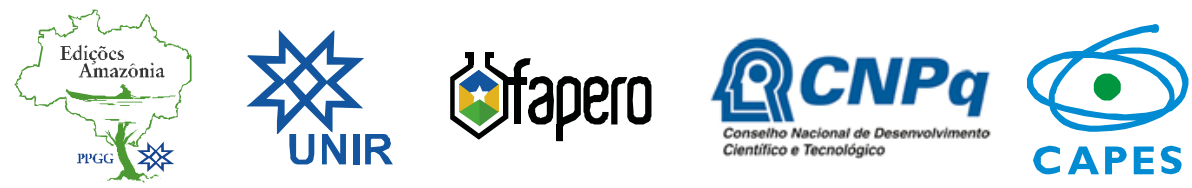


\section{Escutando Sinônimo E LENDo a NATUREZa do EsPaÇO ${ }^{1}$ (LAGET - 10 ANOS POR MAIS 10 ANOS)}

Quando olhamos para trás nestes dias... breves dias, dez anos se passaram e ainda não sabemos quanto tempo a gente leva pra entender a vida... a pesquisa, a chegada e a partida; pra aprender a lutar, a amar sem medida, pra reconhecer os seus desafios e vencê-los.

\section{Quanto tempo?}

Porque quem ama tem sorte, talvez drible a morte em algum dia, porque quem luta deve ser sempre forte, porque o sinônimo da vida é resistir, é viver completamente onde existir.

Mas não são apenas histórias que nos restam, somos mais que vozes e papéis na cabeça de alguém, somos sonhos de algum mal ou de algum bem...

Mas quanto espaço a gente perde pra entender a vida? Pra perder alguém que a gente ama...

Enquanto alguém ainda reclama... quanto espaço?

$O$ lugar que a gente chama de lar de um olhar que se perdeu entre a poeira e a estrada, enquanto você não vê o mundo girar.

O tempo é girassol... porque esse espaço de tempo é o que temos pra ser. Pra onde devemos ir?

\footnotetext{
${ }^{1}$ Livro de Milton Santos.
} 
Pois, bem sabemos que ainda temos duas velhas alternativas:

nos ocultar no fio da ordem existente, inútil, ou amar e lutar, buscando a forma nas funções, para destruí-la, seguindo sempre em frente...

É o suficiente para acreditar, para entender a vida?

Talvez para escrever um Livro Antes que Guardem o Espaço e o Tempo... até outro pesquisador chegar.

Luís Augusto Pereira Lima 


\section{Apresentação}

As motivações para compor esta coletânea decorrem de duas ordens de grandeza que qualifica a proposição acadêmica deste trabalho. Primeiro, o livro inaugura a linha editorial do Programa de Pós-graduação Mestrado e Doutorado em Geografia - PPGG da Universidade Federal de Rondônia - UNIR "Edições Amazônicas PPGG”, que pretende reunir em livros e disponibilizar ao público as pesquisas desenvolvidas na pósgraduação, resultado de teses, dissertações e estudos sistemáticos dos grupos de pesquisas vincu-lados ao PPGG.

Segundo, como um momento de comemoração acadêmica, a coletânea Geografia, Território e Sociedade na Amazônia reúne algumas pesquisas orientadas pelo professor Ricardo Gilson da Costa Silva no PPGG, desenvolvidas e discutidas no Laboratório de Gestão do Território - Laget. Ao longo de 10 anos de existência (2011 a 2021), o Laget proporcionou encontros, diálogos e a formação de dezenas de pós-graduandos de mestrado e doutorado em Geografia da UNIR. As orientações abrangem problemáticas atinentes aos processos socioeconômicos e conflitos territoriais que produzem a geografia das desigualdades socioespaciais na Amazônia.

De modo geral, o Laget encaminha os percursos formativos pela perspectiva da geografia crítica, "que compreende o espaço e as dimensões geográficas da sociedade como produto das formações sociais, e os conflitos agrários e territoriais como resultado das tensões políticas das múltiplas territorialidades em movimento", citação essa contida na página eletrônica do laboratório e do 
Grupo de Pesquisa em Gestão do Território e Geografia Agrária da Amazônia - GTGA/UNIR.

O compromisso político e científico-acadêmico com a problematização dos conflitos agrários e territoriais, assim como as desigualdades socioespaciais subjacentes, a preocupação com os sujeitos sociais, vítimas dos processos de expropriação em curso na região amazônica constituem, em linhas gerais, o eixo deste livro. Evidentemente, os leitores observarão que há poucos textos específicos de Rondônia. Avisamos, antecipadamente, que dedicaremos o segundo livro da linha editorial Edições Amazônicas PPGG às análises das dinâmicas territoriais agrárias de Rondônia, igualmente como resultado de pesquisas orientadas no PPGG, adicionando outras colaborações de parceiros nessa jornada acadêmica. A coletânea está organizada em duas partes. A primeira apresenta como centralidade a Cartografia dos Conflitos Fundiários/ Territoriais e os Povos Amazônicos, composta por cinco capítulos. A segunda parte, assenta-se na análise da "Expansão da Fronteira e Comunidades Rurais Amazônicas", formada por seis capítulos.

O eixo Cartografia dos Conflitos Fundiários/Territoriais e os Povos Amazônicos é formado por um conjunto de textos que problematizam os conflitos produzidos pelos agentes hegemônicos do capital, sempre com apoio do Estado brasileiro, no sentido de ampliar os processos de desterritorialização em larga escala na Amazônia, vitimando comunidades tradicionais, povos originários e campesinos em seus territórios tradicionais. Trata-se, no processo econômico e político, de disputas por território.

Inicia com o artigo "Territórios em disputas na Amazônia brasileira: ribeirinhos e camponeses frente às hidrelétricas e ao agronegócio", publicado em 2018 na Confins (USP e CNRS), de autoria dos professores Ricardo Gilson da Costa Silva (UNIR), Luís Augusto Pereira Lima (Seduc/AM) e Francilene Sales da Conceição (UEA), todos pesquisadores do GTGA/UNIR. A centralidade do texto indica que a região amazônica se converteu em espaço apropriado por megaprojetos (hidrelétricas, agronegócios e mineração), o que demanda um controle maior da dominação/apropriação em larga escala da natureza e dos territórios, instaurando 
uma geografia dos conflitos com os povos indígenas, comunidades tradicionais ribeirinhas e camponeses, apresentando como lócus de estudo os municípios de Porto Velho (norte de Rondônia), Belterra e Santarém (oeste do Pará).

Os conflitos por terra e território compõem as análises dos professores Ricardo Gilson da Costa Silva e Francilene Sales da Conceição, com o artigo "Agronegócio e campesinato na Amazônia brasileira: transformações geográficas em duas regiões nos estados de Rondônia e Pará”, publicado em 2017 na revista Geographia (UFF). O debate articula o conceito de espaços da globalização de Milton Santos para analisar os conflitos que opõem de forma desigual o campesinato e as forças hegemônicas do capital. As evidências empíricas desse processo são observadas em Vilhena (sul de Rondônia), Santarém e Belterra (oeste do Pará), regiões amazônicas com forte inserção da monocultura da soja e permeadas por muitos conflitos territoriais.

A representação cartográfica, como nos demais artigos, assume relevo no estudo "Cartografia das hidroestratégias na Amazônia brasileira", publicado em 2018, na revista Acta Geográfica (UFRR), de autoria dos professores Luís Augusto Pereira Lima e Ricardo Gilson da Costa Silva. Os autores propõem uma reflexão referente aos significados delineados à região amazônica como potencialidade energética. Para isso, desenvolvem o conceito de hidroestratégias para demonstrar que a cartografia crítica articula as dimensões territoriais e os processos políticos e territoriais que tendem a "remover" as comunidades e impactar os lugares onde os grandes projetos hidrelétricos se instalam.

As proposições apresentadas no artigo "Agronegócio produz commodities e agricultura camponesa produz alimentos: o caso da Amazônia brasileira", de autoria da professora Francilene Sales da Conceição e do economista, mestrando do PPGG/UNIR, Wesley Henrique Garcia e Silva, encaminha um estudo comparativo entre a produção da agricultura capitalista (agronegócio) e a produção da agricultura camponesa (campesinato), na Amazônia brasileira, fundamentalmente, nos estados de Rondônia, Pará, Amapá e Roraima, no período de 2010 a 2019. Nesse contexto, a 


\section{Geografia, território e sociedade na Amazônia}

relação contraditória estabelecida entre as duas formas de produção enseja disputas territoriais, pois, o crescimento da produção das commodities agrícolas (soja e milho) tem promovido a espacialização e o agravamento dos conflitos agrários/territoriais na terra/território do campesinato amazônico.

A professora Eubia Andréa Rodrigues (UEA) proporciona, com o texto "O circuito espacial de produção como instrumento de análise de desenvolvimento regional: caso da farinha de mandioca”, uma abordagem de desenvolvimento regional a partir da produção da farinha de mandioca, em análise comparativa entre áreas produtoras dos municípios de Tefé (Amazonas), Cruzeiro do Sul (Acre) e Santarém (Pará). Sua contribuição centra-se na geografia do comércio de um dos produtos base da alimentação regional que tem expressão cultural, o que remete a pensar a alimentação e fluxo econômico no espaço amazônico.

A temática segurança das terras públicas federais é o foco do artigo "Regularização fundiária na Amazônia legal: limitações e expectativas na governança da terra", dos professores Alyson Fernando Alves Ribeiro (pos-doutorando na USP), Hervé Théry (CNRS e USP) e Ricardo Gilson da Costa Silva. Os autores problematizam que a política de regularização fundiária como um instrumento político-jurídico nas relações sociais, impulsionando o mercado de terras no Brasil em escala global. Nessas condições, as terras de domínio comum (públicas) em grandes hectares entram no circuito da troca do capital, generalizando-se a sua dimensão como "mercadoria" e a transferência de ativos públicos para o setor privado.

A segunda parte da coletânea, intitulada "Expansão da Fronteira e Comunidades Rurais Amazônicas" registra as pesquisas referentes ao que parece ser um devir na região, a saga da fronteira que atualmente atinge os territórios protegidos (Unidades de Conservação, Terras Indígenas e Terras Quilombolas). Fronteira, lato sensu, significa transformar áreas naturais em espaços da economia extrativa intensiva, processo que há décadas ocorre com conflitos contra os povos amazônicos, contra os camponeses expropriados, contra a natureza e a estética amazônica. 
O texto que abre o debate encaminha a análise referente à expansão da fronteira no estado com maior área preservada do Brasil. O capítulo "Transamazônica: nova fronteira de expansão e áreas protegidas no estado do Amazonas", publicado em 2021, na revista Mercator (UFC), de autoria dos professores Ricardo Gilson da Costa Silva, Viviane Vidal da Silva (UFAM), Neli Aparecida de Mello-Théry (in memoriam, USP) e Luís Augusto Pereira Lima, contribui para a compreensão das transformações na rodovia Transamazônica, localizada no sul do estado do Amazonas, como um novo eixo de expansão da fronteira. Essa nova frente de expansão invade os territórios ordenados, áreas públicas destinadas à proteção ambiental e ao reconhecimento de territórios tradicionais, o que indica o reavivamento da rodovia BR-230 no circuito das econômicas extrativas.

Em continuidade temática, a relação rodovia e fronteira é discutida no texto "BR-364 - nos confins da fronteira oeste do Brasil: uma via para a integração rodoviária do Acre (Cruzeiro do Sul) com Ucayalli (Pucallpa)", publicado em 2020, na revista Ciência Geográfica (AGB Bauru), pelos professores Ednilson Gomes da Silva (IFAC) e Silvio Simione da Silva (UFAC). Analisam as propostas para a integração regional das faixas de fronteira internacional do extremo oeste brasileiro com o leste peruano, situando a exploração de potencialidades para agropecuária, recursos naturais, rotas comerciais e acesso a portos nos oceanos Atlântico e Pacífico, com possíveis impactos nas cidades de Cruzeiro do Sul (Brasil) e Pucallpa (Peru).

As comunidades tradicionais amazônicas estão presentes, especificamente, em três artigos. A abordagem discutida no artigo "Territórios pesqueiros na Amazônia: dinâmica de pescadores comerciais e de subsistência em comunidade ribeirinha da tríplice fronteira Colômbia-Brasil-Peru", publicado na revista Cerrados (Unimontes), de Erlainy Joanna Souza de Paiva e Ricardo Gilson da Costa Silva, analisa o modo de vida de pescadores do rio Solimões, na tríplice fronteira entre Brasil, Colômbia e Peru e a dinâmica sociogeográfica da comunidade ribeirinha Terezina III, município de Tabatinga (localizada no estado do Amazonas), na qual 
a produção e a comercialização do pescado têm provocado sérios conflitos sociais e territoriais. Conclui-se que o acesso aos recursos pesqueiros deve ser ordenado pelo poder público, com participação social, de modo a fortalecer as comunidades ribeirinhas em seus territórios tradicionais.

O capítulo "O lugar e a várzea amazônica: os espaços cotidianos do camponês amazônico”, publicado em 2021, na revista Ciência Geográfica (AGB Bauru), dos professores Elisane Pereira da Silva (Semed/Oriximiná) e Ricardo Gilson da Costa Silva, tem por finalidade analisar a várzea enquanto lugar do camponês amazônico, evidenciando a relação entre a realidade mais próxima do camponês e as experiências produtivas nos ambientes deste ecossistema. A pesquisa foi realizada nas comunidades ribeirinhas do Furo Cachoeiry, no município de Oriximiná, localizado no oeste do Pará.

Ainda no município de Oriximiná, o avanço do capital mineral nos territórios quilombolas é objeto do capítulo "A subjugação da força de trabalho quilombola ao capital na Amazônia: análise sobre o Quilombo Boa Vista no município de Oriximiná (Pará)”, publicado em 2015, na revista Terr@ Plural (UEPG), de autoria dos professores Silvia da Silva Correa (Semed/Oriximiná), Alyson Fernando Alves Ribeiro e Ricardo Gilson da Costa Silva. A análise focaliza as novas configurações territoriais que submetem a natureza e as populações tradicionais em seus territórios às lógicas de reprodução do capital mineral. Especificamente, o texto direciona a compreender esse processo na comunidade quilombola Boa Vista, seja como força de trabalho assalariada da empresa de mineração, seja nas transformações ocasionadas nas formas de produção e organização do território quilombola.

Encerra o livro, o capítulo "Ruralidades na Amazônia: materializações no espaço urbano de Iranduba e Silves - AM, do geógrafo Matheus Pinto de Souza, mestrando do PPGG/UNIR. O autor analisa as diferentes formas de apropriação do espaço metropolitano que se materializam no campo, espaço rural, a partir da inserção de símbolos comuns ao espaço urbano. Assim, buscou evidenciar as ruralidades no espaço urbano dos municípios 


\section{Apresentação}

de Iranduba e Silves, pertencentes à Região Metropolitana de Manaus (RRM). De forma concomitante, a partir da expansão do perímetro urbano dos municípios estudados, há a incorporação de áreas essencialmente rurais à zona urbana, motivada pelo desejo em captar recursos tributários, desconsiderando a realidade econômica e territorial da população residente.

Para a realização deste trabalho, fruto de pesquisas de mestrado e doutorado do PPGG/UNIR, agradecemos às agências públicas pela concessão de bolsas de pesquisa, dentre elas, a Coordenação de Aperfeiçoamento de Pessoal de Nível Superior - Capes, Conselho Nacional de Desenvolvimento Científico e Tecnológico - CNPq e a Fundação Rondônia de Amparo ao Desenvolvimento das Ações Científicas e Tecnológicas e à Pesquisa do Estado de Rondônia - Fapero.

Pela gentileza e apoio a esse trabalho, agradecemos aos editores e editoras dos periódicos Confins - Revista Franco-Brasileira de Geografia, Geographia - Revista do Programa de Pós-Graduação em Geografia da Universidade Federal Fluminense (UFF), Acta Geográfica - Revista do Programa de Pós-Graduação em Geografia da Universidade Federal de Roraima (UFRR), Mercator - Journal of Geography of the Federal University of Ceará (UFC), Ciência Geográfica - Revista da Associação dos Geógrafos Brasileiros (AGB/Bauru), Cerrados - Revista do Programa de Pós-Graduação em Geografia da Universidade Estadual de Montes Claros - Unimontes, Terr@ Plural - Revista do Programa de Pós-Graduação em Geografia da Universidade Estadual de Ponta Grossa (UEPG).

Ao Programa de Pós-graduação Mestrado e Doutorado em Geografia - PPGG da Universidade Federal de Rondônia - UNIR, pela oportunidade de publicar esta coletânea na Edições Amazônia PPGG/UNIR.

Especialmente à Fapero, pelo apoio financeiro ao Projeto de Pesquisa "Território e Territorialidades em Rondônia: estudo das dinâmicas agrárias e territoriais no norte/noroeste rondoniense”, edital do Programa de apoio à pesquisa (PAP) - Chamada 
Fapero n. 4/2018, coordenado pelo professor Ricardo Gilson da Costa Silva.

Se o conjunto dos textos puder ajudar os leitores a compreenderem melhor as questões atinentes aos conflitos por territórios e natureza na Amazônia, já atingimos, então, nosso objetivo.

Porto Velho (RO) e Manaus (AM), novembro de 2021.

Professores Ricardo Gilson da Costa Silva

e Francilene Sales da Conceição

Organizadores 


\section{SUMÁRIO}

Escutando Sinônimo e lendo a Natureza do Espaço - (Laget - 10 anos por mais 10 anos) 7

Luís Augusto Pereira Lima

\section{PARTE 1 - CARTOGRAFIA DOS CONFLITOS FUNDIÁRIOS/ TERRITORIAIS E OS POVOS AMAZÔNICOS}

1 Territórios em disputas na Amazônia brasileira: ribeirinhos e camponeses frente às hidrelétricas e ao agronegócio 18

Ricardo Gilson da Costa Silva

Luís Augusto Pereira Lima

Francilene Sales da Conceição

2 Agronegócio e campesinato na Amazônia brasileira: transformações geográficas em duas regiões nos estados de Rondônia e Pará 53

Ricardo Gilson da Costa Silva

Francilene Sales da Conceição

3 Cartografia das hidroestratégias na Amazônia brasileira 83

Luís Augusto Pereira Lima

Ricardo Gilson da Costa Silva

4 Agronegócio produz commodities e agricultura camponesa produz alimentos: o caso da Amazônia brasileira 103

Francilene Sales da Conceição

Wesley Henrique Garcia e Silva

5 O circuito espacial de produção como instrumento de análise de desenvolvimento regional: caso da farinha de mandioca 124

Eubia Andréa Rodrigues

6 Regularização fundiária na Amazônia Legal: limitações e expectativas na governança da terra 145

Alyson Fernando Alves Ribeiro

Hervé Émilien René Théry

Ricardo Gilson da Costa Silva 


\section{PARTE 2 - EXPANSÃO DA FRONTEIRA E COMUNIDADES RURAIS AMAZÔNICAS}

7 Transamazônica: nova fronteira de expansão e áreas protegidas no estado do Amazonas 162

Ricardo Gilson da Costa Silva

Viviane Vidal da Silva

Neli Aparecida de Mello-Théry (in memoriam)

Luís Augusto Pereira Lima

8 BR-364 - Nos confins da fronteira oeste do Brasil: uma via para a integração rodoviária do Acre (Cruzeiro do Sul) com Ucayalli (Pucallpa) 183 Ednilson Gomes da Silva

Silvio Simione da Silva

9 Territórios pesqueiros na Amazônia: dinâmica de pescadores comerciais e de subsistência em comunidade ribeirinha da tríplice fronteira ColômbiaBrasil-Peru 218

Erlainy Joanna Souza de Paiva

Ricardo Gilson da Costa Silva

10 O lugar e a várzea amazônica: os espaços cotidianos do camponês amazônico 247

Elisane Pereira da Silva

Ricardo Gilson da Costa Silva

11 A subjugação da força de trabalho quilombola ao capital na Amazônia: análise sobre o Quilombo Boa Vista no município de Oriximiná (Pará) 263 Silvia da Silva Correa Alyson Fernando Alves Ribeiro

Ricardo Gilson da Costa Silva

12 Ruralidades na Amazônia: materializações no espaço urbano de Iranduba e Silves-AM 281

Matheus Pinto de Souza

Súmula Curricular 307 


\section{PARTE 1}

\section{CARTOGRAFIA DOS CONFLITOS FUNDIÁRIOS/ TERRITORIAIS E OS POVOS AMAZÔNICOS}




\title{
TERritórios EM DisPUtas NA AMAZÔNIA BRASILEIRA: RIBEIRINHOS E CAMPONESES FRENTE ÀS HIDRELÉTRICAS E AO AGRONEGÓCIO ${ }^{1}$
}

\author{
Ricardo Gilson da Costa Silva* \\ Luís Augusto Pereira Lima"* \\ Francilene Sales da Conceição ${ }^{\text {****** }}$
}

\section{INTRODUÇÃO}

Há certo consenso entre os pesquisadores de que a Amazônia passa por um conjunto acelerado de transformações socioespaciais que modelam a região, convergindo sua espacialidade em mosaicos territoriais de trabalho e de acumulação de capital. A geografia que se configura na hileia, como argumenta Becker (2006, p. 145), "torna-se um fator determinante para a definição e implementação de políticas de desenvolvimento adequadas às diferentes realidades regionais".

Contudo, o entendimento das diferentes realidades, na escala regional amazônica, vincula-se às demandas de intervenção dita racional do Estado para com os agentes sociais e do mercado, sobretudo, quanto às construções territoriais, o que sugere haver mais de uma Amazônia em disputa no período contemporâneo, situação que nos leva a falar de “imagens amazônicas", visto que a região é complexa e emblemática (Porto-Gonçalves, 2008). A visão múltipla de amazônias se projeta nas

\footnotetext{
${ }^{1}$ Artigo publicado em: COSTA SILVA, R. G.; LIMA, L. A. P; CONCEIÇÃO, F. S. Territórios em disputas na Amazônia brasileira: ribeirinhos e camponeses frente às hidrelétricas e ao agronegócio. Confins (Paris), v. 36, n. 36, p. 1-12, 2018.

* https://orcid.org/0000-0002-3348-9629

** https://orcid.org/0000-0003-0390-4315

*** https://orcid.org/0000-0002-3401-326X
} 


\section{Territórios em disputas na Amazônia brasileira}

sociodiversidades regionais, compostas por modos de vida que entrelaçam natureza e trabalho, de maneira que os contextos geográficos interagem em diferentes escalas.

Isto se reflete nas políticas governamentais e nas escalas de transformações espaciais, cujos efeitos (conflitos sociais e ambientais, entre outros) se expandem em quase todos os lugares da região. No que se refere aos projetos de infraestrutura ou grandes sistemas de objetos (Santos, 1996) que modelam a Amazônia em fixos e fluxos da economia, parecem atingir diretamente os povos e comunidades tradicionais amazônicas, em seus territórios, lugares e modos de vida, sob uma organização territorial duplamente associada ao Estado e ao capital/grandes empresas, com especial ação no espaço rural, que se traduz na produção de fluxos e na conversão da natureza em commodities (Lima; Costa Silva, 2017).

Como objeto de análise deste artigo, centralizamos o estudo: i) nas comunidades ribeirinhas do rio Madeira em correlação às hidrelétricas de Jirau e Santo Antônio, no município de Porto Velho (RO), ii) e nas comunidades camponesas-extrativistas dos municípios de Belterra e Santarém (PA), localizados às margens do rio Tapajós, que enfrentam a expansão do agronegócio da soja.

Assim, nosso objetivo é analisar a geografia que se configura com o processo de transformação da natureza em mercadorias (energia elétrica e soja) a partir de grandes sistemas de objetos que atingem os espaços das comunidades tradicionais amazônicas, partindo do que indicamos como matriz TAE (Território-Ativo-Estratégico), proposta em desenvolvimento para o entendimento do objeto da análise.

Os procedimentos metodológicos adotados foram: levantamento sistemático dos projetos de infraestrutura energética (hidrelétricas), projetos de circulação mercantis (especialmente rodovias e hidrovias), agronegócio (soja); revisão bibliográfica referente aos atuais projetos de infraestrutura vinculados ao objeto do artigo; trabalho de campo nos municípios de Porto Velho (Rondônia), Humaitá e Apuí (Amazonas), Santarém e Belterra (Pará); cartografia temática dos processos socioespaciais em estudo.

Nessa perspectiva, além da introdução e da conclusão, o texto está divido nas seções que analisa: i) a proposição da matriz TAE, ii) seguindo do estudo das hidrelétricas do rio Madeira e as comunidades ribeirinhas na região de Porto Velho, e iii) a análise do agronegócio na região de Santarém e Belterra, no Oeste do Pará. 


\section{Geografia, território e sociedade na Amazônia}

Proposição da matriz Território-Ativo-Estratégico (TAE) para ANÁLISE DA AMAZÔNIA

Avaliamos que a realidade regional amazônica configura o que estamos propondo como estrutura territorial de análise, ou seja, a matriz Território-Ativo-Estratégico (TAE). Nesta matriz, o que se refere a território condiz aos efeitos na sociodiversidade do espaço rural, que resulta em desterritorializações dos povos e comunidades tradicionais e na intensa exploração dos recursos naturais, sobretudo em situações de conflitos socioterrioriais frente aos grandes sistemas de objetos (obras de infraestrutura). Os efeitos das grandes obras podem aparecer distantes, mas estão próximos quanto à Amazônia que se integra, formando um espaço controlado direta ou indiretamente, qualificando-o como território. A parte referida como ativo corresponde aos elementos que compõem a estrutura territorial amazônica, que estão operando e alcançando a potência máxima, haja vista que as fontes energéticas para suprir a operação são os pontos estratégicos na Transamazônica (Tucuruí-PA), Altamira (PA), Itaituba (PA) e Porto Velho (RO) com a rodovia BR-364; estratégico se refere à viabilização correlata de outros elementos territoriais na configuração geográfica, como rodovias federais (BRs) e hidrovias, adicionando mobilidade e potencializando processos modeladores da natureza em sua transmutação econômica como recursos do capital.

A representação espacial (Mapa 1) apresenta os elementos territoriais: status online, em destaque, que estão sob a matriz TAE e que, em princípio, propõe uma sincronia. Nesta proposição sincrônica, observa-se no Mapa 1 que os destaques já operam de forma "legal” após as "conciliações" ambientais e sociais, seja a Mineração Rio Norte (operação), a Vale (operação) e a Belo Sun que articula as intervenções ambientais e sociais; as UHEs de Tucuruí (operação), Belo Monte (operação) e São Luís do Tapajós, cuja intervenção se molda às "exigências" ambientais e sociais. Esses elementos territoriais, atrelados a outros, estão todos localizados no estado do Pará. Todos esses sistemas de objetos, que podemos chamar de megaprojetos, estão, ao mesmo tempo, produzindo energia uns para os outros em larga escala. Considera-se ainda as UHEs do rio Madeira, em Porto Velho (RO), Jirau e Santo Antônio (operação) como ponto de intersecção entre esses elementos territoriais conectados em grande parte pela Transamazônica (BR-230). 


\section{Territórios em disputas na Amazônia brasileira}

Mapa 1 - Grandes sistemas de objetos e elementos territoriais na Amazônia (2017).

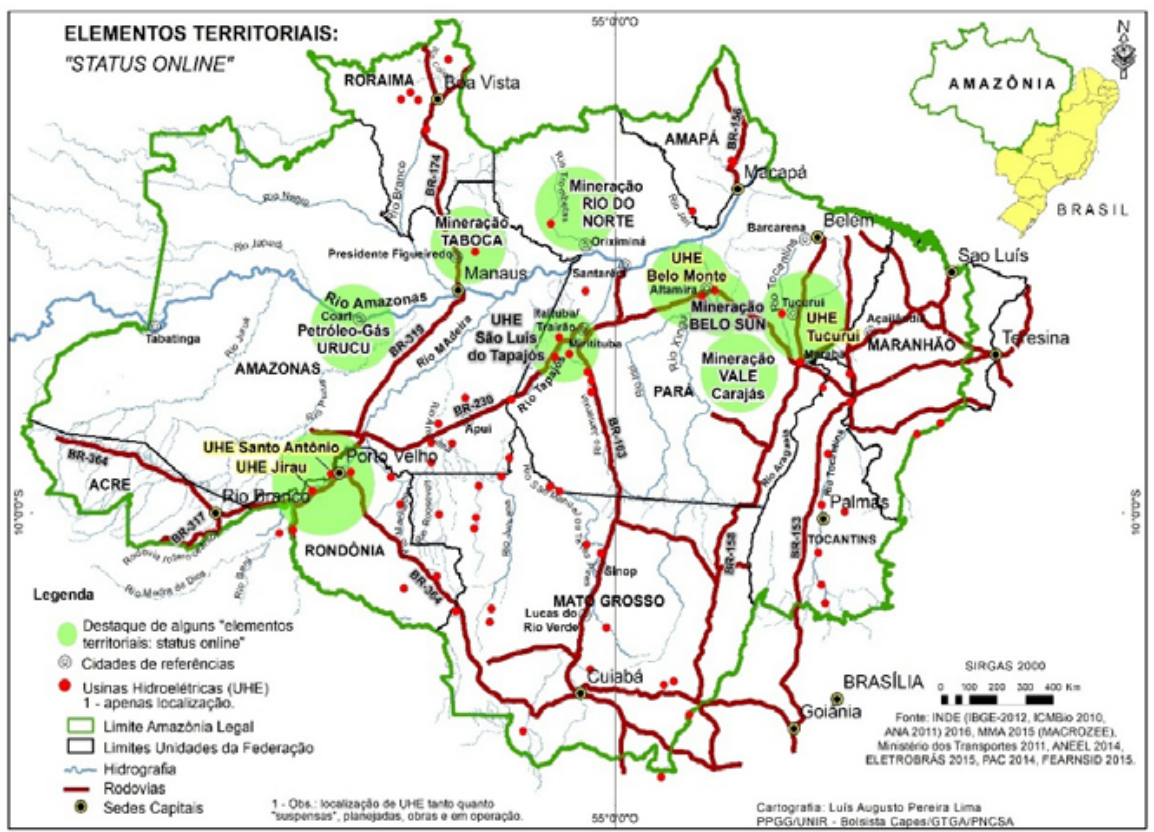

Fonte: L. A. P. LIMA/GTGA/PNCSA/UNIR, 2017.

Na paisagem amazônica perfilam mineração, rodovia e hidrelétrica: mineração da Vale, em Carajás (PA); mineração Rio do Norte, no rio Trombetas, em Oriximiná (PA); e mineração Taboca, no Pitinga, em Presidente Figueiredo(AM) e, recém integradas, Mineração Belo Sun (Altamira-PA) e UHE São Luís do Tapajós (Itaituba-PA) que produzem suas intervenções ambientais e sociais. Citamos estas como referência, pois há outras iniciativas recentes, considerando a existência de estudos comprovados na calha do rio Amazonas, de Tabatinga (AM) à Santarém (PA), como eventuais locais a serem explorados. A esse grupo de elementos podemos acrescentar o Petróleo-Gás do rio Urucu, em Coari (AM), no rio Solimões/Amazonas.

As rodovias federais atreladas às hidrovias constituem a fluidez territorial das empresas, tanto para a mineração quanto para o agronegócio, que priorizam investimentos próximos a esses elementos territoriais. As rodovias federais, cujas siglas são BR-153, BR-158, BR-163, BR-174, BR-230, BR-317, BR-319 e BR-364, associadas às hidrovias 
dos rios Madeira (Maggi), Tapajós (Cargill, Bunge), Tocantins-Araguaia, qualificam a fluidez territorial do agronegócio na região. Tais rodovias, em sua grande parte, tangenciam toda a Amazônia, com tráfego intenso nas principais rotas e em outras, apenas periodicamente, como a BR-319 e a BR-230 (Transamazônica).

A esses elementos territoriais adiciona-se as hidrelétricas (UHE) de Jirau² e Santo Antônio ${ }^{3}$, no rio Madeira, em Porto Velho (RO); a UHE Tucuruí $^{4}$ no rio Tocantins, em Tucuruí (PA) e a UHE Belo Monte ${ }^{5}$, em Altamira (PA), no rio Xingu, que, em conjunto, podem fornecer, em curto prazo, cerca de mais de 26 mil MW de potência instalada, ou seja, energia dita "limpa" ao Operador Nacional do Sistema Elétrico (ONS). Relacionamos apenas essas hidrelétricas para uma análise inicial, pois há mais de três dezenas de UHE na região, sejam suspensas, canceladas, em obras, em planejamento ou em operação, como as relacionadas.

A matriz TAE delineia a dinâmica de pressão econômica e, mesmo, de destruição dos territórios dos povos e comunidades tradicionais amazônicas de forma sistemática, considerando que as ações políticas do capital tendem a impor outro ordenamento territorial, a partir das mudanças jurídicas referentes aos direitos territoriais. Pode-se perceber que esses elementos territoriais, ativos e estratégicos, do ponto de vista do capital e do Estado, norteiam o processo produtivo no espaço geográfico, cuja ação preliminar se baseia na escala do controle do território. Esse controle incidi na superfície dos rios (hidrovias) e da água (hidrelétricas), na superfície terrestre relativa ao campo (agronegócio/ commodities), na floresta (madeireiras) ou no subsolo (mineração).

A representação Território-Ativo-Estratégico deriva de uma situação geográfica anterior que, no momento, atinge o ápice das relações e interações territoriais de dominação. Vislumbra-se que, desde o lançamento do Plano de Integração Nacional (PIN-1970) ${ }^{6}$, essa estratégia ainda segue a sua inscrição de integração em curto ou a longo prazo (Becker, 2006; Lima; Costa Silva, 2017). A produção e transformação

\footnotetext{
${ }^{2}$ Cf. www.esbr.com.br (potência instalada $3.750 \mathrm{mw}$ )

${ }^{3}$ Cf. www.santoantonioenergia.com.br (potência instalada $3.568 \mathrm{mw}$ )

${ }^{4}$ Cf. www.museuvirtualtucurui.com.br (potência instalada $8.370 \mathrm{mw}$ )

${ }^{5}$ Cf. www.norteenergia.com.br (potência instalada 11.233,1 mw)

${ }^{6}$ Cf. www.planalto.gov.br. Visava ou ainda visa integrar a região amazônica à economia nacional.
} 


\section{Territórios em disputas na Amazônia brasileira}

do território não são indiferentes às ações pretéritas das formas-conteúdo do espaço objeto da ação (Santos, 1996; Raffestin, 2015). Esses "modos" que configuram a geografia da Amazônia, a matriz TAE, a nosso ver, cujos elementos territoriais têm a mesma procedência, operam distintamente sob a combinação das políticas governamentais, constituindo-se a partir de programas, planos e projetos, que agem em cooperação (Estado e Capital) no controle do território.

A matriz Território-Ativo-Estratégico pode ser concebida a partir do "afastamento-operação-produção", em que há um afastamento gradativo das comunidades tradicionais dos recursos naturais, em virtude de os megaprojetos entrarem em operação e em estágio produtivo, na qual se sobrepõe à reivindicação de direitos humanos e territoriais dos povos amazônicos. Nesse sentido, sugerimos que as comunidades tradicionais amazônicas estão em processo territorial de afastamento e de desterritorialização, em função da presença espacial dos grandes sistemas de objetos em áreas amazônicas até então distantes da ação do capital e do Estado, áreas essas consideradas periféricas na escala regional e nacional.

O que entendemos como TAE se configura como um espaço em que as mineradoras tendem a alcançar novas áreas periféricas, haja vista as áreas de potássio previstas em Autazes, município do estado do Amazonas, como produto estratégico à produção do agronegócio, ou mesmo a prospecção mineral em áreas quilombolas para a extração de bauxita no alto Trombetas (Oeste do Pará). Nesta ótica, as rodovias federais chegam aos espaços efetivamente transformados em atividades produtivas, coletando das "artérias" que circulam e escoam a produção do agronegócio, em sentido norte. Assim, observa-se no Mapa 1 a hidrovia Madeira-Amazonas, de Porto Velho (RO) à Itacoatiara (AM), atrelada à soja; a rodovia BR-163, de Cuiabá (MT) à Santarém (PA), mas antes, conectado ao porto de Miritituba, em Itaituba (PA) transportando soja; a BR-364, de Porto Velho (RO)/Rio Branco (AC) à Cuiabá (MT), também como corredor de grãos e outras commodities, ou seja, o agronegócio como potencializador desses fluxos.

As hidrelétricas (capital), por sua vez, dominam os rios com a expectativa de produção de energia em larga escala, considerando apenas que " 51 das UHE com > $30 \mathrm{MW}$ " instaladas na Amazônia ao final dos planos, obras e as em operação podem produzir cerca de mais de 60 mil MW (Fearnside, 2015, p. 15). Sublinhamos que as UHEs de Jirau, 


\section{Geografia, território e sociedade na Amazônia}

Santo Antônio, Tucuruí, Belo Monte e São Luís do Tapajós ${ }^{7}$ (após conclusão das obras), juntas, em curto prazo, podem chegar a produzir mais de $50 \%$ dessa potência referida por Fearnside (2015).

Essa realidade pode ser conhecida, mas a situação em questão demonstra que os elementos territoriais estão combinados e continuam a imprimir uma geografia na Amazônia a partir dos "grandes projetos" produzidos para o "progresso ou crescimento", pela associação Estado/ Capital que se contrapõem aos territórios e aos modos de vida assentados em comunidades ribeirinhas e camponesas, distanciando-se da perspectiva de sustentabilidade socioambiental que balizou, desde a década de 1980, muitas políticas públicas na região.

Se relacionarmos aos anos de 1970, temos a implantação do PIN. No momento atual, verifica-se as seguintes condições das principais rodovias federais na Amazônia: parcialmente asfaltadas, asfaltadas ou em conclusão, mas com intenso fluxo de transporte e carga. Como referência, em trabalho de campo no município de Apuí (AM), constatamos o fluxo diário de ônibus de passageiros interestadual, a exemplo da empresa Amatur, com fluxo no trajeto de Porto Velho (RO), pela BR-319, depois via Transamazônica (BR-230) até Apuí (AM). Deste município, três vezes por semana, a empresa Buburé faz o percurso por Jacareacanga, Itaituba, Altamira até Marabá (municípios localizados no estado do Pará), além de outros tipos de transportes de cargas e passageiros. Os principais rios da Amazônia barrados ou em processo, como Madeira, Tapajós, Xingu, Araguaia e Tocantins, por exemplo, dinamizam a geração de energia para outros megaprojetos que, até então, era impossível, do ponto de vista do abastecimento de energia, mas que, de fato, indica que quase tudo está funcionando, como as hidrelétricas que algum dia foram apenas ideias de projetos!

Sob essas considerações, a geografia que se imprime na Amazônia opera no sentido em que os investimentos públicos e privados se ancoram na tríade Território-Ativo-Estratégico. Pode-se considerar, ainda, a concessão para duplicação da $\mathrm{BR}-364^{8}$; a ferrovia prevista no

\footnotetext{
7 Cf. Informação de potência instalada nas UHEs disponíveis em Barragens na Amazônia www.dams-info.org/pt

8 Cf. Senadonotícias - Disponível em www.12.senado.leg.br
} 


\section{Territórios em disputas na Amazônia brasileira}

trecho da BR-163, de Lucas do Rio Verde (MT) à Miritituba $(\mathrm{PA})^{9}$, trecho de Açailândia (MA) à Barcarena (PA) e outro de Anápolis (GO) à Palmas (TO) ${ }^{10}$ previstas no Programa de Investimentos em Logísticas (PIL) do governo federal; BR-163, trecho de Mato Grosso do Sul (MS) à Sinop $(\mathrm{MT})^{11}$ sob a o consentimento da Concessionária Rota do Oeste, e deste ponto ao porto de Miritituba(PA) que será asfaltada ${ }^{12}$, de acordo com o Ministério dos Transportes, além do trecho até Santarém(PA); esta geografia se articula ainda com a hidrovia Tocantins-Araguaia ${ }^{13}$ que tem "contornado" as intervenções ambientais e sociais de conflito em Marabá (PA). Esse rol de elementos territoriais compõe o leque de ações que demandam investimentos do Estado e da iniciativa privada, numa escala de ascensão sincrônica, haja vista, haver energia elétrica como princípio básico para investimentos em produção, a exemplo da mineração da Belo Sun, em Altamira (PA).

\section{HidRelÉTRICAS E OS RIBEIRINHOS DO RIO MADEIRA}

$\mathrm{Na}$ convergência dos fatores associados à matriz Território-Ativo-Estratégico (TAE), sublinhamos a observação do contexto fisiográfico da Amazônia em inúmeros itens. Poderíamos identificar o rio Amazonas como maior rio do planeta, a própria floresta Amazônica ou a sua biodiversidade e sociodiversidade, em suma, o que se enquadra na escala de transformação objetiva desta reflexão nos remete ao panorama

9 Cf. www.canalrural.com.br. "Alternativa à BR-163, governo fará concessão para construção da Ferrogrão" - 5 de março de 2017. "A ferrovia está na carteira do Programa de Parceiras de Investimentos (PPI), mas é uma iniciativa das próprias tradings. Elas elaboraram o projeto e o apresentam ao governo em 2014, informando estarem dispostas a investir em sua construção. São sócias nesse projeto: Amaggi, ADM, Bunge, Cargill, Dreyfus e a EDLP. A estimativa é que a linha custará R \$ 12,6 bilhões”.

10 Cf. www.epl.gov.br. Programa de Investimentos em Logística (PIL). "Ferrovia Norte-Sul (trechos Açailândia/MA - Barcarena/PA e Palmas/TO - Anápolis/GO) (Estudos entregues)".

11 Cf. www.rotadooeste.com.br. Concessionária Rota do Oeste.

12 Cf. www.brasil.gov.br. "BR-163 será pavimentada até Miritituba, no Pará" - 17 de Agosto de 2017. "A principal via de escoamento de milho e soja do Centro-Oeste para os portos do Arco Norte estará pavimentada até 2018. O Ministério dos Transportes, Portos e Aviação Civil destina R\$ 128,5 milhões para obras na BR-163/PA”.

13 Cf. www.brasil.gov.br. "Obra permitirá navegação na hidrovia Tocantins-Araguaia”. Aguarda a remoção do Pedral do Lourenço nas proximidades de Marabá. 
intrínseco dos grandes sistemas de objetos. Por isso, existem algumas hidrelétricas na Amazônia, dentre elas Samuel, Jirau e Santo Antônio, sendo que estas duas últimas são de grande porte, localizadas em uma única cidade amazônica, Porto Velho, a capital do estado de Rondônia.

Há outras cidades na Amazônia com hidrelétricas em suas adjacências urbanas, mas nenhuma com duas UHE de grande porte, diretamente alocadas inteiramente no município de Porto Velho. A UHE de Jirau está localizada a $120 \mathrm{~km}$ da área urbana propriamente dita, enquanto Santo Antônio está pouco mais de $7 \mathrm{~km}$ do centro comercial da cidade de Porto Velho, que já desponta como cidade/capital regional segundo a Divisão Urbano-Regional do IBGE (2013).

Os principais distritos do município estão diretamente impactados pelas UHEs. Esses distritos, de Abunã à Calama e suas respectivas comunidades ribeirinhas sofreram as intervenções das UHEs, por mais que tenham recebido "compensações sociais", definitivamente, perderam seus territórios, alteraram seus modos de vida e passaram a vivenciar um complexo de incertezas, seja nos modelos de reassentamentos ou de indenizações financeiras, medidas que destoam da condição cultural e territorial dessas comunidades (Almeida, 2009).

Figura 1 - Propaganda da UHE Jirau referente à vila Nova Mutum Paraná (2015).

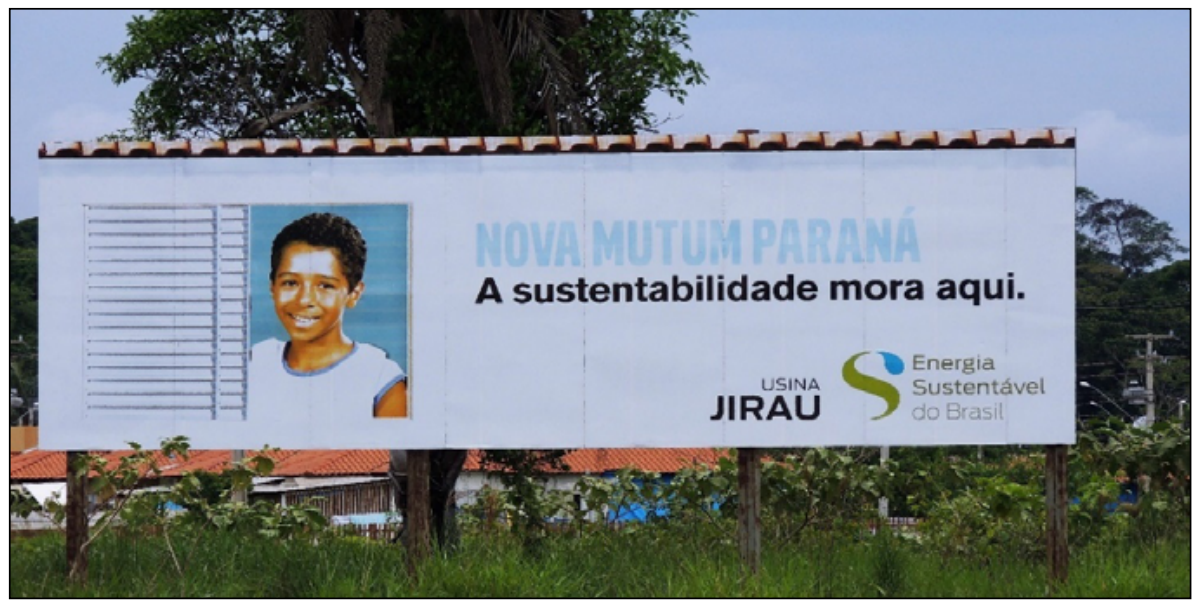

Fonte: Trabalho de Campo. Acervo: GTGA/UNIR. 


\section{Territórios em disputas na Amazônia brasileira}

Essa foi a situação geográfica construída às comunidades tradicionais "deslocadas" de seus territórios. As áreas oferecidas para reassentamentos são inadequadas, com muita dificuldade para a atividade agrícola, a não ser com o "fornecimento" de adubo como "compensação". A pesca, prática tradicional, ficou distante do rio, perdendo completamente a relação dinâmica dos ribeirinhos, enquanto os produtos do extrativismo se renderam às mercadorias industrializadas. $\mathrm{O}$ cultivo das roças e das pequenas criações não seria possível manter como atividade produtiva, dado o aumento do lençol freático, impactado pelo represamento do rio Madeira à montante da cidade de Porto Velho. Na vila Nova Mutum (Figura 1), cujo "modelo" de reassentamento urbano inviabilizou as relações e condições de reprodução material e simbólica da vida ribeirinha agroextrativista, assim como o comércio local, ocorreu uma grande evasão e abandono de famílias ali reassentadas, visto as condições avessas aos fundamentos culturais e de territorialidade dos ribeirinhos (PNCSA, 2014, p. 3).

As UHEs de Jirau e de Santo Antônio “impuseram temporalidades aceleradas ao cotidiano urbano e rural, constituindo-se como evento dinamizador da geografia de Porto Velho" (Costa Silva, 2015, p. 1). A perspectiva da temporalidade acelerada se desenvolve a partir da constituição de territorialidades que indicam correlações com as abordagens emergentes de recursos para a indústria, neste caso, a energia produzida por usinas hidrelétricas que compõe o leque das demandas locais e nacional. Essa perspectiva emana das condições do primado discurso oficial da "aceleração do crescimento" e designa ações sobre os territórios das comunidades amazônicas, tal qual ocorrido nos territórios ribeirinhos do rio Madeira. A abordagem se dá frente ao modo de vida comunitário amazônico, que os mantém ao longo dos rios e florestas. No entanto, a imposição de tal temporalidade condiciona os agentes sociais às novas formas aceleradas do processo social, seja na relação de trabalho, quanto em certa atmosfera social mediada pelos processos técnicos da vida cotidiana (Saquet, 2015; Santos, 1996).

A temporalidade imposta pelas UHEs para com as comunidades ribeirinhas do Madeira significa "ritmos mais rápidos", de maneira que as desigualdades proliferaram a partir das instalações das usinas. Os lugares das comunidades ribeirinhas se transformam e seus significados passam a incorporar as atividades hegemônicas do capital hidrelétrico, que engendra ainda mais as desigualdades no território (Costa Silva, 2010, p. 50; Ribeiro; Franca, 2016; Almeida, 2009). 
Os deslocamentos compulsórios das comunidades, sejam ribeirinhos diretamente atingidos, camponeses assentados da reforma agrária, sejam moradores próximos aos locais das grandes obras, demarcam como fator desigual nesse processo de acesso aos recursos naturais substituídos pelas compensações "financeiras" das UHEs. Entendemos que a funcionalidade desigual do território e seus corolários permanecem com as comunidades amazônicas, ficando com o capital hidrelétrico o lucro em potencial. Esta relação contraditória, mediada pelo Estado, no sentido de imposição de uma dinâmica como prática recorrente dos "empreendedores" dos grandes projetos, tem prevalecido como a característica principal da geografia de Rondônia e em praticamente toda a região amazônica.

$\mathrm{Na}$ geografia apresentada no Mapa 2, localizam-se os efeitos da temporalidade acelerada do capital e a desterritorialização das comunidades ribeirinhas depois das barragens no rio Madeira. Trata-se da imposição de relações socioeconômicas que expropriaram direta ou indiretamente as comunidades amazônicas e o próprio recurso hídrico e paisagístico, como o desaparecimento de inúmeras ilhas e cachoeiras. Nesta cartografia social, qualificada pelos os impactados, submersos, "deslocados" e desterritorializados, destacam-se os Distritos de Mutum Paraná (Nova Mutum, Nova Vida), Jacy-Paraná, São Carlos, a (Vila) Jirau e Vila Amazonas; as comunidades de Engenho Velho (Novo Engenho Velho), Santo Antônio, Teotônio (Vila Teotônio), Riacho Azul, São Domingos, Trata Sério, Sacaca, Joana D’Arc I, II, III (Santa Rita), São Sebastião; as cachoeiras Santo Antônio, Teotônio, Morrinho, Caldeirão do Inferno, Jirau, Embaúba, Três Irmãos, Vai Quem Quer, Prainha, Machado, Paredão, Tamborete, Penha, Taquaras, Araras, Ribeirão e Misericórdia; e as ilhas do Padre, da Pedra, Santana, Niterói, Jacy-Paraná, Liverpool, Porto Seguro. 
Mapa 2 - Comunidades ribeirinhas impactadas pelas hidrelétricas do Madeira (2017).

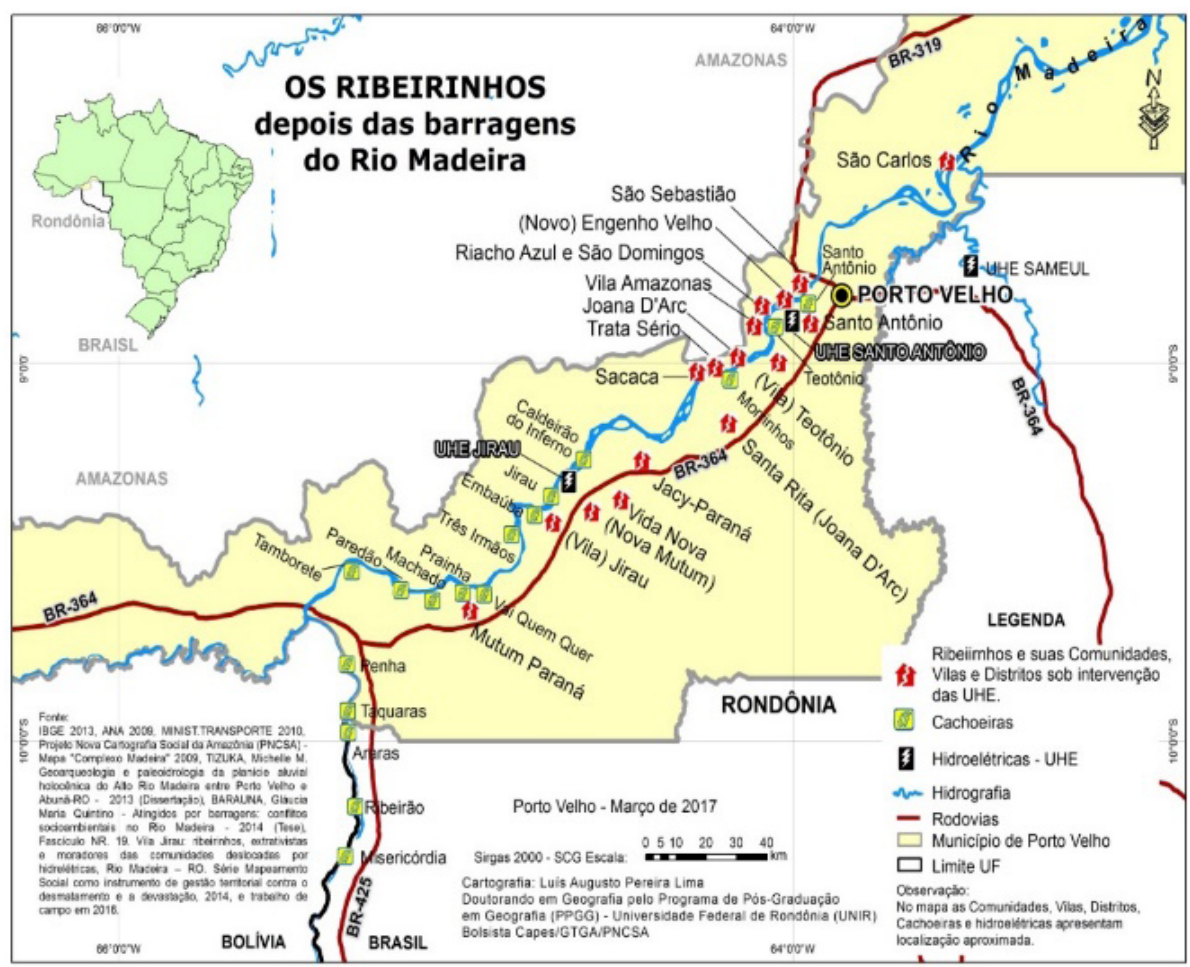

Fonte: L. A. P. LIMA/GTGA/PNCSA/UNIR, 2017.

Relações e dinâmicas de um conjunto de elementos do contexto geográfico do Complexo Madeira, que faziam parte das especificidades territoriais das comunidades, como elemento social de autonomia e resistência, agora estão submersos, em grande parte, submetidos às temporalidades e espacialidade das hidrelétricas do Madeira. O Mapa 2 localiza as comunidades ribeirinhas que foram desterritorializadas, que não contemplam mais o natural caminho do rio Madeira. As hidrelétricas, estas estranhas catedrais agora estão no meio do rio (Sevá, 2008), representam a expansão do progresso inscrito nos mapas oficiais onde não estão e nem estiveram as comunidades tradicionais amazônicas. Com esta representação oriunda de sobreposição e de expropriação territorial das comunidades amazônicas, assim, foram instaladas no rio Madeira as usinas de Jirau e Santo Antônio. 
Os "rastros dos deslocados" não desapareceram, no entanto, os "rastros" das usinas estão em "Nova Mutum", "Novo Engenho Velho", "Joana D’Arc - Santa Rita", "Vila Teotônio", bairro Triângulo, São Sebastião, São Carlos, nas cachoeiras e ilhas submersas. As cachoeiras, outras vezes submersas pelas cheias do Madeira e seu curso natural, depois das barragens, permanentemente, resta na paisagem o lago das hidrelétricas que ostentam ainda ampliar em $80 \mathrm{~cm}$ a quota do lago, especificamente, Santo Antônio Energia (SAE).

Nesta perspectiva, a ordem e progresso do crescimento econômico, expressa em termos práticos a Integração das Infraestruturas Regionais Sul-Americanas (IIRSA) articulada ao Programa de Aceleração do Crescimento (PAC), em que a Amazônia brasileira está sob a matriz TAE. Esta projeção se demonstra a partir do Quadro 1, que resume a compensação financeira pela utilização de recursos hídricos da ANEEL, dos royalties pagos referentes aos "valores recolhidos pelas concessionárias”.

Quadro 1 - Royalties pagos derivado da Hidrelétrica de Santo Antônio (2013/2016).

\begin{tabular}{|c|c|c|c|c|c|c|c|c|}
\hline \multicolumn{9}{|c|}{ ROYALTIES - SANTO ANTÔNIO ENERGIA (SAE) } \\
\hline ANO & $\begin{array}{c}\text { RO } \\
\text { PA }\end{array}$ & $\begin{array}{l}\text { LTIES } \\
\text { O R\$ }\end{array}$ & UNI & $10 \%)$ & RON & & & $45 \%)$ \\
\hline 2012 & \multirow{3}{*}{ R\$ } & \multirow{3}{*}{59,9} & \multirow{3}{*}{$\mathbf{R S}$} & \multirow{3}{*}{6,0} & \multirow{3}{*}{ RS } & \multirow{3}{*}{26,95} & \multirow{3}{*}{ RS } & \multirow{3}{*}{26,95} \\
\hline 2013 & & & & & & & & \\
\hline 2014 & & & & & & & & \\
\hline 2015 & RS & 63,3 & RS & 6,3 & RS & 28,5 & RS & 28,5 \\
\hline 2016 & RS & 72,1 & R\$ & 7,2 & R\$ & 32,45 & RS & 32,45 \\
\hline TOTAL * & RS & 195,3 & RS & 19,5 & RS & 87,9 & R\$ & 87,9 \\
\hline
\end{tabular}

Obs.: estimativa em R\$ milhões. Percentuais ( \% ) conforme www.aneel.gov.br.

* Valores arredondados para análise segundo royalties pagos de R \$195.304.729,14

de março de 2012 a dezembro de 2016 disponível <www.santoantonioenergia.com.br>.

Fonte:

Site da SAE e Quadro Resumo de Compensação Financeira pela utilização de Recursos Hídricos, disponível em <www.aneel.gov.br>. Acessado em 09 de março de 2017. Adaptado e estimado por Lima, 2017. 
Quadro 2 - Royalties pagos derivados da Hidrelétrica de Jirau (2013/2016).

\begin{tabular}{|c|c|c|c|c|c|c|c|c|}
\hline \multicolumn{9}{|c|}{ ROYALTIES - ENERGIA SUTENTÁVEL DO BRASIL (ESBR) } \\
\hline ANO & \multicolumn{2}{|c|}{$\begin{array}{l}\text { ROYALTIES } \\
\text { PAGO RS }\end{array}$} & \multicolumn{2}{|c|}{ UNIÃO (10\%) } & \multicolumn{2}{|c|}{ RONDÔNIA (45\%) } & \multicolumn{2}{|c|}{ PORTO VELHO (45\%) } \\
\hline \multicolumn{9}{|l|}{2013} \\
\hline \multicolumn{9}{|l|}{2014} \\
\hline 2015 & & 61,7 & R\$ & 6,2 & R\$ & 27,75 & $\mathbf{R} \$$ & 27,75 \\
\hline 2016 & & 60,9 & $\mathbf{R} \$$ & 6,1 & R\$ & 27,4 & R\$ & 27,4 \\
\hline TOTAL * & R\$ & 122,6 & $\mathbf{R} \$$ & 12,3 & R\$ & 55,2 & $\mathbf{R} \$$ & 55,2 \\
\hline
\end{tabular}

Obs.: estimativa em R \$ milhões. Percentuais ( \% ) conforme www.aneel.gov.br.

* Valores arredondados para análise.

Fonte:

Site ANEEL, conforme Quadro Resumo de Compensação Financeira pela utilização de Recursos Hídricos, disponível em <www.aneel.gov.br>. Acessado em 09 de março de 2017. Adaptado e estimado por Lima, 2017.

Os quadros 1 e 2 demonstram os dados dos royalties pagos pelas usinas hidrelétricas ao Governo Federal (União), Governo de Rondônia e Município de Porto Velho. Representam os valores que também poderiam chegar indiretamente aos ribeirinhos e às comunidades desterritorializadas. Verifica-se que os recursos financeiros destinados a Porto Velho já compreendem valores que dispensam comentários mais profundos, cuja ação social parece não objetivar as comunidades "reassentadas", mas significa sublinhar, dado que esses recursos poderiam ser empregados nos serviços sociais, como saúde, educação e transporte urbano/comunitário nas comunidades atingidas e também na cidade de Porto Velho.

No entanto, as compensações ainda não contemplaram diretamente as demandas dos ribeirinhos, permanecem em "conta-gotas", haja vista que existem ações judiciais desde o início das obras das usinas hidrelétricas em muitas comunidades, como é o caso "Nova Mutum", onde existe "uma dívida social em aberto". De outra maneira, os dados referentes aos royalties pagos pela Energia Sustentável do Brasil (ESBR-Jirau) e a Santo Antônio Energia (SAE) delineiam apenas as atuações no 


\section{Geografia, território e sociedade na Amazônia}

sentido de tentarem "compensar" a destruição causada às comunidades amazônicas, seguindo a legislação vigente. Podemos considerar que esses valores não contemplam as demandas em andamento das comunidades afetadas, a exemplo da vila Nova Mutum, pois, os valores relacionados nos quadros com os royalties pouco chegam aos ribeirinhos. As mitigações com infraestruturas propostas pelos consórcios das UHEs tangem perspectivas urbanas distanciadas da realidade social vivenciada nas comunidades ribeirinhas do rio Madeira. As compensações proferidas pelas usinas ainda não sanaram os danos e intervenções, pois privilegiam ações pontuais, em longo prazo, com novas moradias, desarticuladas das relações sociais dos grupos atingidos pelas barragens.

Os valores dos Quadros 1 e 2 objetivam demonstrar o quantitativo, segundo informações da $\mathrm{SAE}^{14}$ e da ANEEL, de mais de 140 milhões de reais recolhidos e destinados ao município de Porto Velho depois de entrarem em operação (Sae 2012; Esbr 2013). Considerando a nota 1 , a SAE prevê um montante em royalties ainda mais expressivo. Sob esse prisma, as UHE pré-definem que estão "seguindo a lei" referente ao "devido" recolhimento pelo uso dos recursos hídricos, conforme a designação dos percentuais para União, Estado e Município. Sobre isso, revelam que as "compensações" devidas pelos consórcios das usinas, desde o início dos estudos de impactos ambientais e sociais foram negligenciadas até a fase de operação definitiva, pois, registram-se situações de passivo social por compensação em curso nas vilas de Nova Mutum, Vida Nova, assentamentos Joana D'Arc, dentre outros que constam nos depoimentos registrados na publicação do PNCSA ${ }^{15}$.

14 Cf. www.santoantonioenergia.com.br. A partir de 2017, em plena operação, a Hidrelétrica Santo Antônio irá pagar em torno de R\$ 100 milhões por ano em royalties pelo uso das águas do rio Madeira. Os recursos serão divididos da seguinte maneira: $45 \%$ para o município de Porto Velho, 45\% para o estado de Rondônia, 3\% ao Ministério do Meio Ambiente, 3\% ao Ministério de Minas e Energia e 4\% ao Fundo Nacional de Desenvolvimento Científico e Tecnológico (FNDCT). Cabe ao Poder Público direcionar os recursos a serviços e obras para a população.

15 Cf. www.novacartografiasocial.com. PNCSA. Fascículo NR. 19. Vila Jirau: ribeirinhos, extrativistas e moradores das comunidades deslocadas por hidrelétricas, Rio Madeira-RO. In: Nova Cartografia Social da Amazônia. Série Mapeamento Social como instrumento de gestão territorial contra o desmatamento e a devastação, 2014. 
Consideramos que os mantenedores, segundo informações do consórcio da UHE Jirau (ESBR), disponíveis em seu site ${ }^{16}$, compõem uma Sociedade de Propósito Específico (SPE), cujo capital social é integralmente detido pela ESBR Participações S.A., que tem como acionistas as empresas ENGIE (40\%), nova denominação da GDF SUEZ, Eletrobrás Eletrosul $(20 \%)$, Eletrobrás Chesf $(20 \%)$ e Mizha Participações S.A. $(20 \%)$, subsidiária da Mitsui \& CO., LTD, são os responsáveis diretos pela destruição causada às comunidades ribeirinhas a partir da instalação da usina.

Em outra ponta, a UHE Santo Antônio Energia (SAE) ${ }^{17}$, conforme informado em seu site, item a "Usina em Números", se inscreve na mesma linha de responsabilidade constituída pelo "Consórcio Madeira Energia S.A (MESA), que possui como acionistas Furnas Centrais Elétricas S.A. (39\%); Odebrecht Energia do Brasil S.A. (18,6\%); SAAG Investimentos S.A. (12,4\%) controlada pela Andrade Gutierrez; Cemig Geração e Transmissão S.A. (10\%) e Caixa Fundo de Investimentos em Participações (FIP) Amazônia Energia (20\%)".

\footnotetext{
16 Cf. www.esbr.com.br/empresa\#a-usina-hidreletrica-jirau. Acesso em: 18 jan. 2018.

17 Cf. www.santoantonioenergia.com.br/empresa/usina-em-numeros. Acesso em: 18 jan. 2018.
} 
Geografia, território e sociedade na Amazônia

Figura 2 - Placa informativa das instituições financiadoras da UHE Jirau (2015).

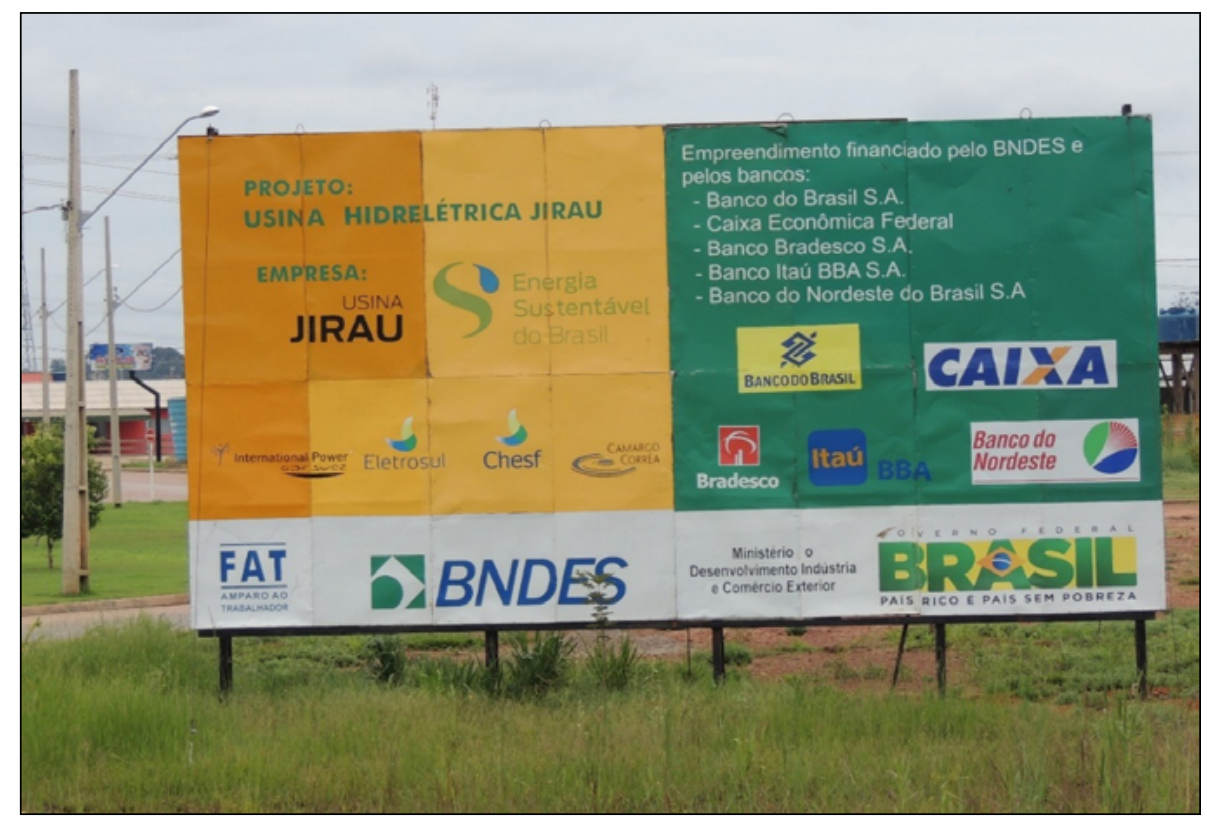

Fonte: Trabalho de Campo. Acervo: GTGA/UNIR, 2017.

Neste caso, como os outros acionistas da ESBR (Figura 2) e da SAE, neste contexto, nos quadros de royalties pagos, também está a Caixa Econômica Federal (CEF), cuja participação no empreendimento da SAE dá-se pelo "Caixa FIP Amazônia Energia”, com 20\% das ações. Segundo o site da $\mathrm{CEF}^{18}$, o FIP tem como um dos quotistas a Odebrecht Energia do Brasil. O FI (Fundo de Investimentos) - FGTS - "patrimônio líquido do FGTS, que tem por finalidade investir em projetos de saneamento e infraestrutura nos setores de rodovias, portos, hidrovias, ferrovias e energia" que é administrado pela própria CEF, mas a gestão é da Valor Investimentos, aparece como o segundo maior quotista da SAE. Esta observação revela uma "participação" indireta dos trabalhadores brasileiros. Contudo, devem existir regras em que os trabalhadores não podem configurar nesta relação, mas, a sigla do Fundo de Garantia por

${ }^{18}$ Cf. www.caixa.gov.br/fgts. Acesso em: 18 jan. 2018. 


\section{Territórios em disputas na Amazônia brasileira}

Tempo de Serviço (FGTS), que somam suas "reservas" trabalhistas é proponente da destruição indireta dos trabalhadores, dos ribeirinhos e das comunidades tradicionais amazônicas.

Dessa maneira, conforme visto nos quadros, os recursos financeiros direcionados ao estado de Rondônia e, especificamente, ao município de Porto Velho poderiam suscitar uma transformação econômica e um amplo progresso social do ponto de vista dos serviços públicos, diminuindo o que Costa Silva e Conceição (2016) compreendem como uma "diferença social" entre Porto Velho e os principais municípios de Rondônia. Sob tal argumento, a cidade de Porto Velho "experimentou as virtudes do crescimento populacional e econômico, mas não soube redistribuir esses ativos em progresso social” (Costa Silva; Conceição, 2016, p. 244).

O contexto dessa falta de "progresso social” ou as mitigações e compensações das usinas inadequadas às condições demandadas penalizam as comunidades tradicionais desterritorializadas do rio Madeira. Em Nova Mutum, uma Vila criada para assentar as famílias desterritorializadas, uma dívida social está em aberto, conforme consta nos trabalhos de campo do Projeto Nova Cartografia Social da Amazônia- PNCSA:

É que tem uma questão em aberto, o pessoal que foi para Nova Mutum ficou com uma dívida, porque Nova Mutum não resolveu a vida das pessoas, então ficou em aberto e a empresa ficou com uma dívida social em aberto, então esse passivo não pode fechar, então a gente tá tentando traduzir em que palavra coloca para exigir da empresa (ESBR) esse passivo, ou seja, essa dívida que ela tem, principalmente com o pessoal que morava em Mutum(Paraná) e foi transferido, não conseguiu se reequilibrar em Nova Mutum, veio pro Jirau (Vila Jirau) e precisa ser compensado, mas não necessariamente com dinheiro, mas com estrutura (Jackson, p. 6-7, 2014, PNCSA - Fascículo n. 19) [Grifo nosso].

Em realidade, existem muitas situações de passivo social não resolvido, decorrente das UHE do Madeira, principalmente no que se refere ao atendimento das demandas sociais derivadas dos desalojamentos comunitários. A energia produzida às margens de uma cidade que se deslocou de uma "cidade ribeirinha" para uma "cidade regional" (Costa Silva; Conceição, 2016, p. 223), ver a soma dos recursos produzidos pelas UHE seguindo às "linhas de alta tensão" do Sistema Integrado Nacional, rumo ao Sudeste do país. Fato é que, o próprio catálogo do 


\section{Geografia, território e sociedade na Amazônia}

Programa Nacional do Meio Ambiente (Pnma, 1995, p. 44), do governo federal, já sublinhava tal subtração. As desterritorializações das comunidades ribeirinhas são visíveis no espaço local, enquanto o fluxo da energia segue a uma escala nacional.

Considerando que a constatação dos "benefícios" segue outro rumo, já datam mais de 20 anos de "modelo" expropriador dos recursos e dos territórios que ainda vigoram de forma "legítima" em Porto Velho e na Amazônia. Como contraponto, Porto Velho ostenta uma reconfiguração que convergiu para a construção das UHE e divergiu quanto à destruição das comunidades tradicionais amazônicas, pescadores e ribeirinhos do rio Madeira, principalmente nas comunidades e vilas ribeirinhas do alto rio Madeira (Costa Silva, 2016a; 2016b).

As hidrelétricas do Madeira configuram um cenário na região que podemos qualificar como um "conglomerado de territórios como ativos estratégicos" para a exploração profunda da Amazônia. A geografia amazônica que se evidência perpassa pela combinação dos efeitos produzidos pelos grandes projetos, sempre numa associação entre Estado e capital.

\section{Agronegócio e camponeses no Oeste do Pará}

A mesorregião do Baixo Amazonas possui suas especificidades e singularidades socioespaciais, sendo formada pelos municípios de Santarém, Belterra, Mojuí dos Campos, Placas, Óbidos, Oriximiná, Juruti, Alenquer, Almeirim, Curuá, Prainha, Monte Alegre, Porto de Moz, Faro e Terra Santa. Deste modo, como recorte espacial adotado nesta pesquisa, os municípios de Santarém e Belterra demonstram que as comunidades rurais têm modificado as formas de interação com a natureza, em virtude do desenvolvimento do agronegócio, materializando-se como a geografia das commodities (Valbuena, 2008-2009; Conceição, 2017).

A dimensão espacial dos municípios de Santarém e Belterra é caracterizada por uma sociodiversidade, uma pluralidade cultural e econômica emblemática, em que a cidade de Santarém se destaca por sua centralidade administrativa no contexto regional do Baixo Amazonas. Toda essa multiplicidade de eventos que compõe o cenário do Oeste da Amazônia paraense, bem como seus respectivos modos de vida, caracteriza o panorama organizacional da vida social dos sujeitos que trabalham e habitam na zona rural. O acesso a esses municípios ocorre por via fluvial, através dos rios Tapajós, Amazonas, Arapiuns e seus afluentes, ou pela rodovia 
Cuiabá-Santarém (BR-163). Partindo desse mosaico socioeconômico, que garante a reprodução social dos povos do campo, das águas e das florestas, é que o campesinato tem seu modo de vida ameaçado e seus recursos naturais comprometidos para se tornarem propriedade privada ou serem transformados em mercadorias conexas ao mercado global.

Esses dois municípios são alvos da expansão do capital global no espaço agrário, florestal e hídrico amazônico, onde a lógica contraditória do agronegócio sojeiro transformou a natureza e a força de trabalho (relação social) em mercadorias; apropriou e expropriou o campesinato extrativista; tecnificou e homogeneizou o ambiente agroflorestal tapajônico e introduziu o agrotóxico nos cultivos agrícolas para elevar a produtividade, negando substantivamente a geografia do campesinato do alto, médio e baixo rio Tapajós (Conceição, 2017).

Figura 3 - Multinacional Cargill às margens do rio Tapajós em Santarém-PA.

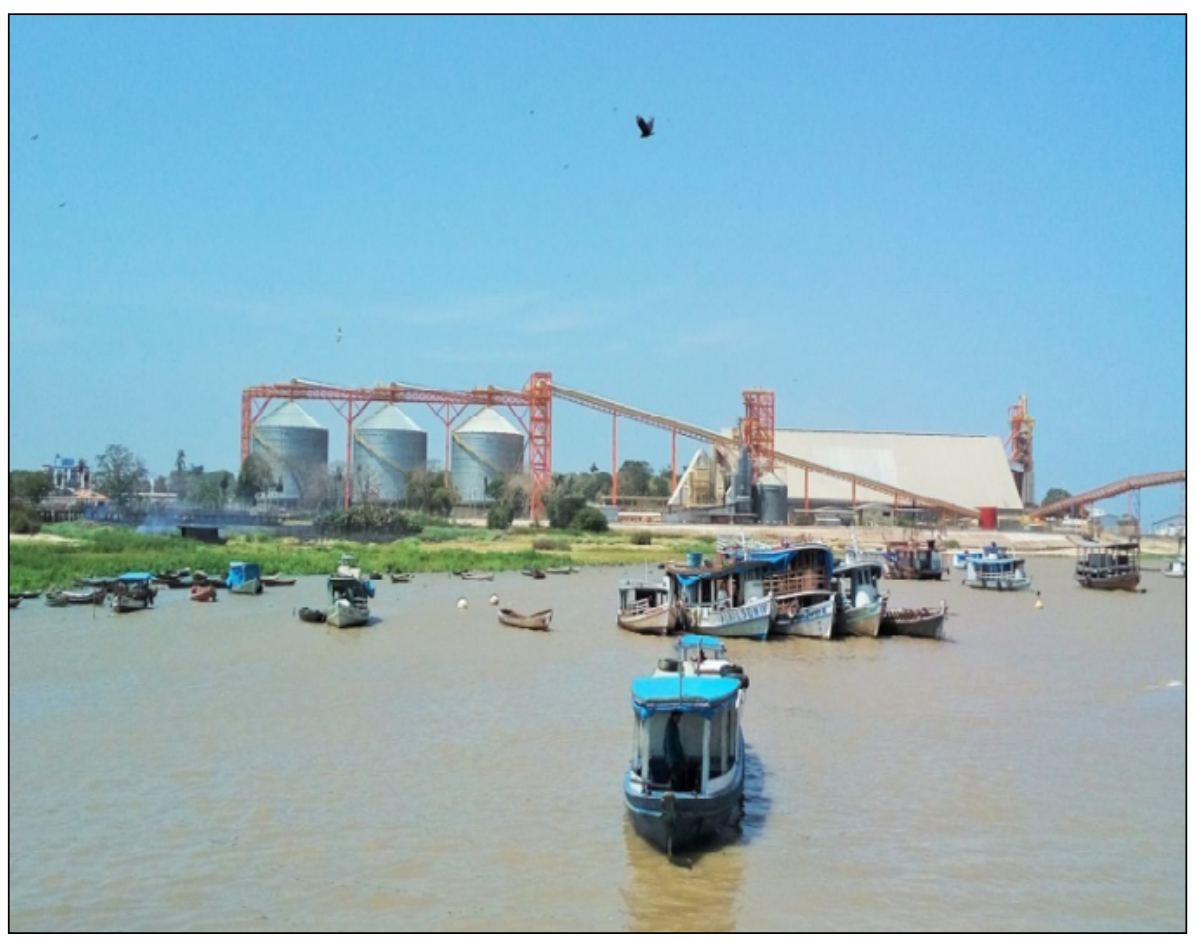

Fonte: Trabalho de campo, 2016. Foto: F. S. da Conceição. 
O agronegócio se territorializou no Oeste paraense porque é um espaço estratégico e promissor para a produção, transporte e distribuição de granéis sólidos (soja e milho) que transitam pelo corredor da soja, a BR-163, chegando até ao porto da Cargill, localizada às margens do rio Tapajós (Figura 3). A ação hegemônica tem atribuído para novas formas de apropriação e domínio coercitivo e persuasivo sobre os territórios campesinos, cujas territorialidades contêm suas coexistências no campo, nas florestas e nas águas/rios (Costa Silva; Conceição, 2017).

A posição geográfica de Belterra (Bela Terra) e Santarém (Pérola do Tapajós) tem como um de seus referenciais os rios Tapajós e Amazonas, por meio do encontro destes rios em frente à cidade de Santarém, conhecido como o Encontro das Águas, um patrimônio imaterial, que na memória dos paraenses do Oeste do estado, é carregado de encantamentos, mistérios, sentimentos/emoções, exuberância paisagística e significação material e imaterial que permite a reprodução social da vida dos amazônidas paraenses (Conceição, 2017).

A base econômica sempre teve centralidade nas práticas extrativas/ ribeirinhas e policultoras de natureza familiar. Mas, atualmente, está sendo modificada e pressionada por um novo modelo de "desenvolvimento" e símbolo de "progresso": o agronegócio da soja. Essa conjuntura predominante na região alcança os grupos sociais residentes ou que se encontram sob a influência da região do Tapajós e Amazonas (Figura 4 A e B).

Figura 4 - Usos dos rios Tapajós e Amazonas no Oeste do estado do Pará.

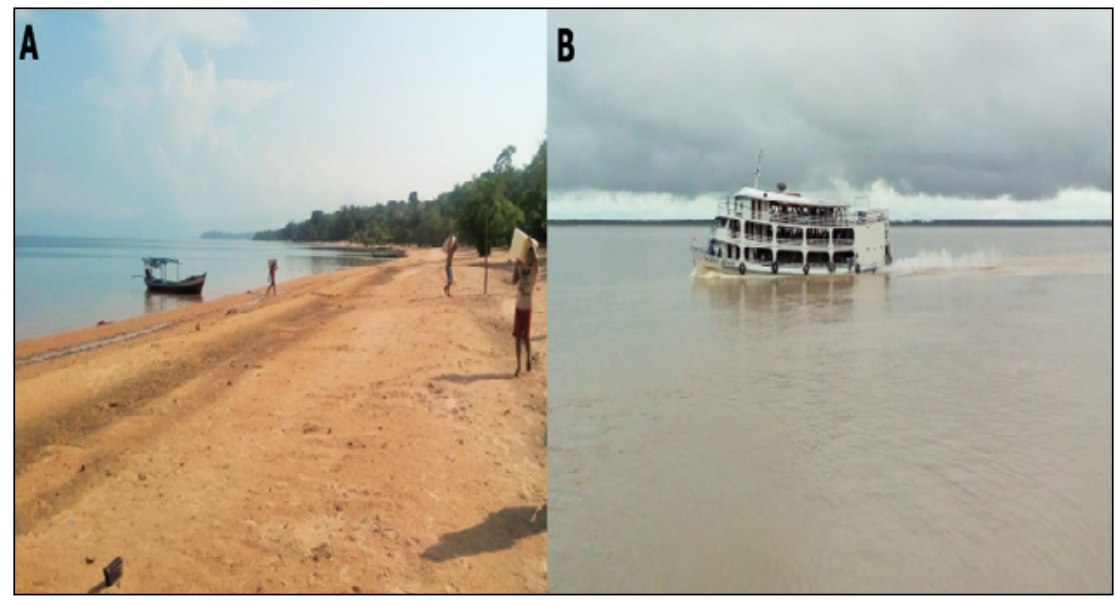

Fonte: Trabalho de campo, 2016. Foto: F. S. da Conceição. 


\section{Territórios em disputas na Amazônia brasileira}

Os rios, para as comunidades ribeirinhas, além de significarem fontes de reprodução da vida, realçam o espaço ribeirinho como potencialidade na gênese dos alimentos, pois a multiplicidade de pescados é o indicador de que a pesca fluvial faz parte da dieta alimentar de muitas famílias ribeirinhas, a qual é fruto de um trabalho autônomo e um atributo que contribui diretamente, ora como fonte de alimentos, ora como fonte da renda familiar das populações da região do Baixo Amazonas (Lima et al., 2016).

Esse processo reforça um espaço ribeirinho de grande utilidade para a gênese dos transportes de pessoas que percorrem as vias fluviais, o qual se define, consecutivamente, por pontos de partidas e chegadas aos destinos originários e que conectam as cidades ribeirinhas (Trindade Júnior et al., 2011) ou cidades fluviais amazônicas, por meio do uso de embarcações de pequeno e médio porte. Retrata também a gênese dos transportes para a comercialização dos produtos extrativos e da agricultura camponesa, pois os fluxos dos produtos oriundos do trabalho familiar atendem o comércio local e regional.

No contexto regional, a lógica espaço-temporal e o ponto de referência equivalente à posição geográfica entre os lugares é medida pelas margens esquerda e direita, aonde a dimensão concreta das espacialidades, das temporalidades e do imaginário construídos pelos sujeitos ribeirinhos, enquanto condição de ser social, lutam cotidianamente para se manter no território campesino, florestal e fluvial, a fim de vivificar e dinamizar as (re)existências e fortalecer suas identidades socioculturais.

$\mathrm{Na}$ Amazônia há uma variedade de tipologias de campesinato que possui especificidades ao se relacionar com a natureza, mas, cabe aqui, nesse estudo, denominar de campesinato extrativista, por entender que na essência de seu modo de vida a produção oriunda do extrativismo (vegetal e animal) se configura como fonte de renda e subsistência para muitas famílias, bem como garante a conservação e uma relação de aprendizagem com o meio ambiente, uma relação dialógica do ser humano com a natureza.

Todavia, não é do costume dos camponeses, principalmente para aqueles que habitam as confluências do Tapajós, desenvolverem uma única atividade. A pesca, a caça, a coleta extrativa, a fruticultura, a horticultura, as legumiculturas, a criação de animais de diferentes espécies e outras culturas temporárias e mesmo as culturas permanentes são indispensáveis à vida camponesa. Essas atividades são desenvolvidas pelas famílias, cujo escopo do processo se concretiza por meio do trabalho 
familiar que visa atender as necessidades das famílias, o que se caracteriza como soberania alimentar.

Segundo a Prefeitura Municipal de Belterra (2010), os produtos provenientes da agricultura camponesa (frutas, legumes, verduras, pescado e criação de animais) abastecem a cidade de Santarém e os mercados de Manaus (AM), Belém (PA), Macapá (AP). Esse fato coloca em evidência a economia e produção local e regional, valorizando as atividades desenvolvidas pelas comunidades rurais que objetivam a subsistência, o comércio regional e a geração de emprego e renda. Dado que os princípios norteadores da estrutura organizativa camponesa são a produção familiar, a solidariedade comunitária e as relações de parentesco que se contrapõem à lógica do agronegócio, o que nos parece é que as formas de capital do agronegócio objetivam romper os laços estabelecidos em comunidade, metamorfoseando a terra, a floresta e o rio, em mercadorias, em commodities (Conceição; Costa Silva, 2017; Costa Silva, 2017).

Mapa 3 - Comunidades agroextrativistas da região do rio Tapajós, Belterra-PA (2018).

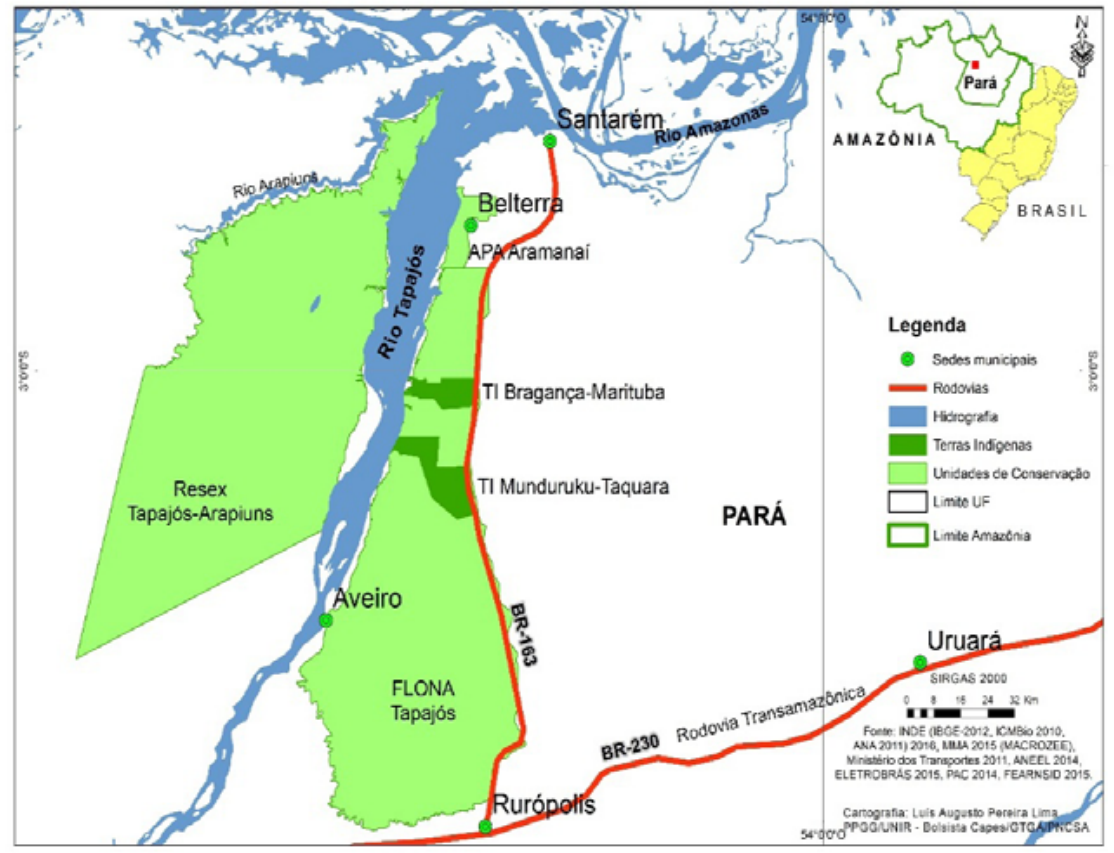

Fonte: L. A. P. LIMA/GTGA/PNCSA/UNIR, 2017. 


\section{Territórios em disputas na Amazônia brasileira}

Particularmente, a produção de grãos expandiu-se velozmente no oeste paraense. Nos últimos dados registrados, em 2016, Santarém apresentou 43.200 toneladas e Belterra 41.016 toneladas. Este último teve sua produção elevada, onde as áreas de matas ou capoeiras ${ }^{19}$ e de pastagens foram convertidas em terras de lavouras agrícolas, elevando a pressão sobre as reservas florestais e instaurando a coerção sobre os territórios campesinos e indígenas (Mapa 3), a exemplo das terras indígenas TI Bragança-Marituba e TI Munduruku-Taquara, situadas na região do Tapajós (Costa Silva; Conceição, 2017).

De acordo com os dados disponibilizados pelo IBGE, a área plantada do percentual de soja em 1997, no município de Santarém, foi de $0,36 \%$, enquanto nos quatros últimos anos o quantitativo, em 2011, passou a 32,98\%, em 2012 correspondeu a 32,38\%, em 2013 se referia a $26,46 \%$ e em 2015 equivaleu a 28,05\%. Apesar de Santarém ter um salto bem expressivo nos números, atualmente, esses dados tiveram uma queda referente à taxa total da produção de soja, em virtude da emancipação de Mojuí, para o qual agora pertence muitas áreas dessa produção, não sendo mais contabilizado em Santarém.

No município de Belterra a soja iniciou em 2002, correspondendo a $1,62 \%$ da área plantada. Nos últimos anos a leguminosa mostrou seu potencial produtivo: em 2011 alçou a taxa de $41 \%$, em 2012 apontou 38,31\%, em 2013 o percentual foi de 36,26\% e em 2015 alcançou o equivalente a $45,02 \%$ da área plantada. Percebe-se que os dados apresentados pelo município indicaram a elevação no percentual de área plantada.

Entretanto, nesses municípios, o plantio da commodity não apenas corresponde ao aumento do quantitativo da produção de grãos, mas, aos impactos da racionalidade do capital nos territórios campesinos e na natureza. Na medida em que agronegócio se expande sobre os territórios campesinos e sobre a massa florestal, desterritorializa-se o campesinato extrativista e coloca em processo de destruição as comunidades camponesas de base ribeirinha-extrativa, cuja temporalidade e a lógica sociocultural se baseia nos elementos terra-rio-floresta como reprodução social do modo de vida amazônico, diferente do capital, que objetiva, sobretudo, sua reprodução ampliada (Costa Silva; Conceição, 2017).

19 Formação de uma vegetação secundária (segunda natureza) após a mata virgem (primeira natureza) ter sido desmatada para algum tipo de atividade de produção. 
No caso de Belterra, o crescimento espacial da soja atingiu o perímetro urbano e a zona de expansão de lavouras (Figura 5), resultando em conflitos e nas irregularidades fundiárias que ameaçam as áreas de proteção ambiental, como as áreas rurais do Planalto da BR-163, local dos projetos de colonização implementado desde a década de 1970 pelo governo federal; da Floresta Nacional do Tapajós (FLONA), onde reside a maioria da população ribeirinha que vive da produção agroextrativista; e da Área de Preservação Ambiental Aramanaí (APA), onde vivem populações ribeirinhas, extrativistas e agricultores, conforme indicação no Mapa 3.

Figura 5 - Área do perímetro urbano do município de Belterra-PA (2018).

\section{Área Urbana e do agronegócio em Belterra/PA}

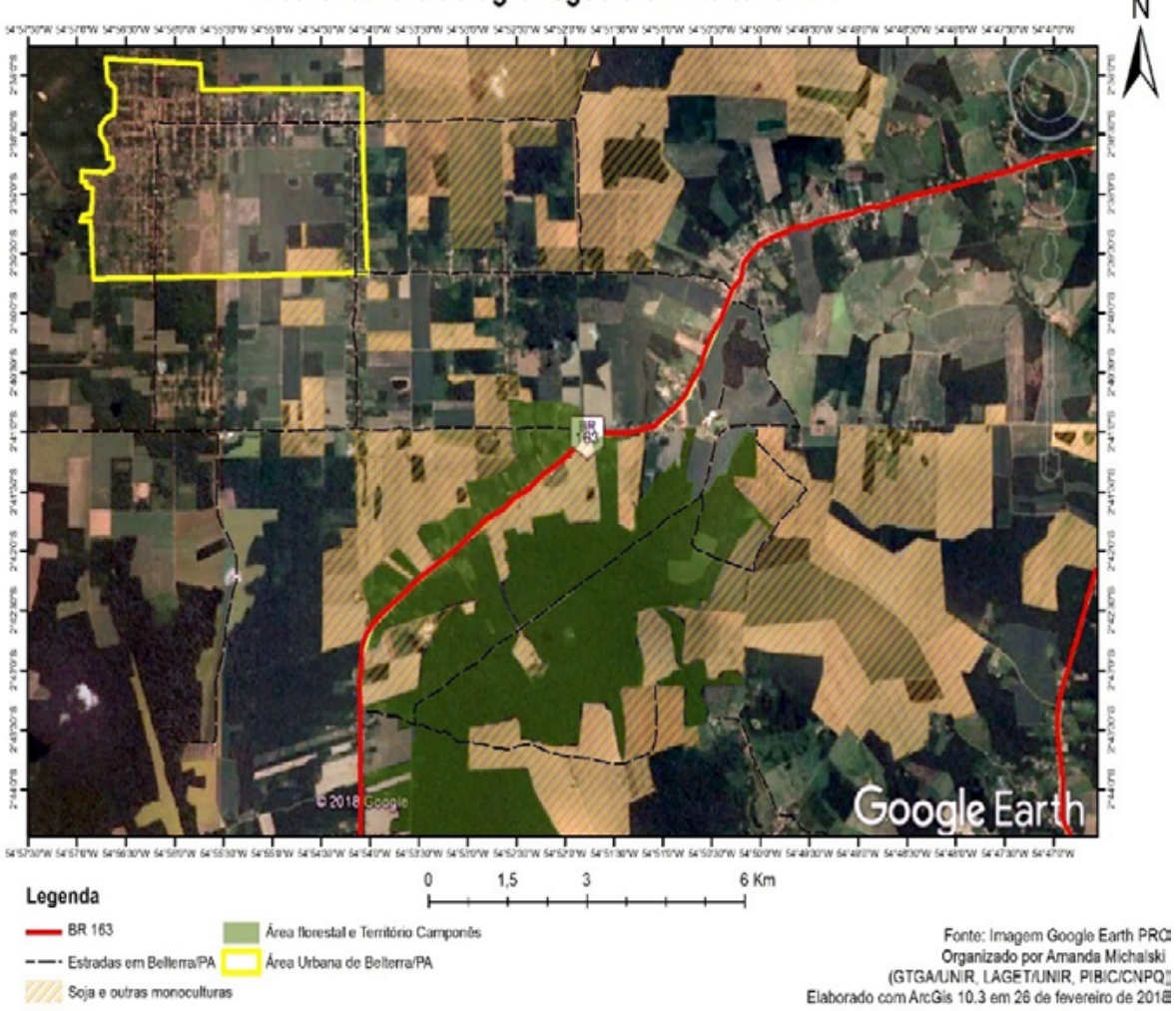

Fonte: Laget/UNIR, 2018. 
Territórios em disputas na Amazônia brasileira

Quadro 3 - Produção agroextrativista e ribeirinha no município de Belterra-PA.

\begin{tabular}{|c|c|c|}
\hline Áreas & Categorias & Produção \\
\hline $\begin{array}{l}\text { BR-163 } \\
\text { (rural) }\end{array}$ & $\begin{array}{l}\text { Agricultores e } \\
\text { extrativistas }\end{array}$ & $\begin{array}{l}\text { Plantação de mandioca, grãos (arroz, feijão, } \\
\text { milho), pimenta do reino, limão, laranja } \\
\text { tangerina, cupuaçu, abacaxi, melancia, abó- } \\
\text { bora, dentre outras produções de frutas, le- } \\
\text { gumes e verduras e criação de animais como } \\
\text { ovelha, gado, porco e galinha e extração de } \\
\text { produtos na floresta. }\end{array}$ \\
\hline $\begin{array}{l}\text { FLONA } \\
\text { Tapajós } \\
\text { (rural) }\end{array}$ & $\begin{array}{l}\text { Agricultores, extra- } \\
\text { tivistas, pescadores } \\
\text { ribeirinhos, peque- } \\
\text { nos comerciantes. }\end{array}$ & $\begin{array}{l}\text { Plantação de mandioca e seus derivados (fa- } \\
\text { rinha, beiju e tapioca), abóbora feijão, café, } \\
\text { banana, etc; coleta de andiroba, copaíba, } \\
\text { leite de seringa, mel de abelha, cumaru e } \\
\text { mamona; da pesca e da caça: cotia, veado } \\
\text { do mato e anta; além do artesanato (penei- } \\
\text { ras, colares e cestas). }\end{array}$ \\
\hline $\begin{array}{l}\text { APA } \\
\text { Aramanaí } \\
\text { (rural) }\end{array}$ & $\begin{array}{l}\text { Pescadores ribeiri- } \\
\text { nhos, extrativistas, } \\
\text { agricultores e barra- } \\
\text { queiros e pequenos } \\
\text { comerciantes. }\end{array}$ & $\begin{array}{l}\text { Açaí, cupuaçu, palmeiras, patchouli, etc. } \\
\text { Vivem da atividade pesqueira e prestam ser- } \\
\text { viços aos visitantes turistas (hospedagem e } \\
\text { alimentação). }\end{array}$ \\
\hline $\begin{array}{l}\text { Porção } \\
\text { Urbana }\end{array}$ & $\begin{array}{l}\text { População migrante } \\
\text { (nordestinos, ex-se- } \\
\text { ringueiros), cabo- } \\
\text { clos, ribeirinhos e } \\
\text { agricultores. }\end{array}$ & $\begin{array}{l}\text { Funções e cargos públicos, comércios, tra- } \\
\text { balho autônomo (construção civil, mototá- } \\
\text { xi, culinária), agricultura urbana (produção } \\
\text { de farinha e seus derivados e de frutas como } \\
\text { cupuaçu, graviola, manga taperebá, laranja, } \\
\text { abacate, abacaxi entre outras desenvolvidas } \\
\text { nos quintais ou próximos ao perímetro ur- } \\
\text { bano). }\end{array}$ \\
\hline
\end{tabular}

Fonte: Prefeitura Municipal de Belterra, 2010. Organização: F. S. da Conceição, 2017.

Como estão assinaladas no quadro demonstrativo (Quadro 3), os grupos sociais que trabalham, habitam e vivenciam os espaços do campo, das águas e das florestas, tem sua composição histórico-geográfica de vida e de trabalho no agroextrativismo e no alicerce ribeirinho. Portanto, na medida em que a soja expande sobre áreas que judicialmente se encontram irregulares e de responsabilidade da União, tem-se um campesinato 


\section{Geografia, território e sociedade na Amazônia}

extrativista em processo de despojo, onde a geografia tapajônica é dominada e apropriada territorialmente pela lógica do capital.

Além da territorialização e do monopólio da Cargill em Santarém, e da Amaggi no distrito de Miritituba, município de Itaituba, exercendo grande controle sobre o território e articulando estratégias de mercados para a comercialização de grãos em nível global, outros projetos hegemônicos são pensados para o oeste do Pará, a fim de fortalecer e subsidiar o circuito produtivo das leguminosas, aumentando, assim, as coerções territoriais (Costa Silva, 2017).

Nesse sentido, o Governo Federal planeja políticas territoriais, investindo diretamente em sistemas logísticos no oeste da Amazônia paraense, voltadas para as rodovias, hidrovias, ferrovias. A construção desses modais devem responder as expectativas das exportações de soja. Seus objetivos pautam pela redução em torno de $40 \%$ nos custos do valor dos fretes gastos com os transportes de grãos (Costa Silva; Conceição, 2017).

Como exemplo dessa proposta do avanço do agronegócio, no Oeste paraense, estão:

1) a construção de três portos graneleiros pela Empresa Brasileira de Portos de Santarém (Embrapa), na margem direita do rio Amazonas, na cidade de Santarém-PA;

2) a construção pela Cargill na rodovia BR-163, no município de Belterra, um estacionamento para carretas;

3) a construção da hidrovia do Tapajós, que, no discurso do capital, é necessária para o escoamento da produção de grãos e minérios pela Região Norte e Centro-Oeste e representa uma alternativa de "baixo impacto ambiental", comparado com as rodovias que afirmam ter grandes prejuízos, pois seus custos são exorbitantes e geram danos ambientais maiores;

4) outra ação de grande investimento voltado para outro projeto aprovado recentemente é a construção da Ferrogrão, uma ferrovia que interliga Sinop, no Norte do Mato Grosso, ao distrito de Miritituba, no Pará. Os principais interessados na construção desse modal ferroviário são as tradings Amaggi, ADM, Bunge, Cargill, Louis Dreyfus, cujo início das obras está previsto para 2019. 


\section{Territórios em disputas na Amazônia brasileira}

Os projetos resultam dos acordos estabelecidos entre Estado e capital, pois a depender dos interesses e estratégias postas pelo Programa de Investimentos e Logísticas (PIL), do Governo Federal, das corporações do agronegócio e seus aliados, esse projeto se concretiza na sua totalidade, legitimando a negação, a subjugação e a destruição dos territórios camponeses, visto que, nesses territórios, a prática ribeirinho-extrativa, onde morada e trabalho constituem ambientes familiares, diferencia-se do ambiente de negócio, da concentração da terra e especulação fundiária. Nesse cenário desigual e excludente, vislumbra-se a criminalização e a violação dos direitos humanos dessas comunidades agroextrativistas, ao passo que cresce a mercantilização da natureza para concretizar as monoculturas de soja (Costa Silva, 2017).

A geografia agrária no oeste paraense mostra que as terras, as águas (rios) e as florestas se tornam, cada vez mais, objeto de mercantilização, em que o capital ao dar outra forma-conteúdo ao território e introduzir uma nova funcionalidade no espaço que era de uso do campesinato extrativista, gera exclusão e oposição à diferentes formas de vida social na Amazônia paraense.

O agro/flora/hidronegócio corresponde ao desenvolvimento do capitalismo no campo-rio-floresta, comportando-se como a materialização da globalização do espaço agrário no oeste do estado do Pará, cujo conhecimento técnico, científico e informacional assinala um lugar mais aberto ao mundo, alterando as dinâmicas territoriais locais entre agronegócio sojeiro e o campesinato extrativista, cristalizado por meio das conflituosidades que avançam sobre espaço tapajônico.

\section{Conclusão}

Os estudos das comunidades ribeirinhas no município de Porto Velho (Rondônia) e das comunidades camponesas extrativistas, nos municípios de Belterra e Santarém (oeste Pará), demonstram como suas geografias estão sendo transformadas pelo avanço das grandes obras hidrelétricas e do agronegócio da soja, configurando o espaço regional amazônico com sistemas de objetos que, definitivamente, ampliam em seus territórios a escala geográfica da relação social.

As situações geográficas analisadas convergem para o entendimento de que os recursos do território se tornaram um ativo econômico poderoso, mobilizando o capital para áreas até então consideradas distantes dos tentáculos das empresas nacionais e multinacionais. Nesse 


\section{Geografia, território e sociedade na Amazônia}

sentido, os grandes sistemas de objetos alcançam o que podemos qualificar como Amazônia profunda, onde o tempo-espaço ainda não foram convertidos em sociabilidade do capital, mas que comparece como potência, como um "vir a ser" do espaço do capital.

$\mathrm{O}$ que a pesquisa nos permite concluir, ainda que provisoriamente, é que a busca intensiva por recursos naturais, como mercadorias da economia global, atinge lugares e territórios que ainda se caracterizam como amálgama da relação ser humano e natureza, territórios permeados por processos de aprendizagem sociocultural, que antes estavam “distantes" dos fluxos econômicos. Falamos, pois, da Amazônia dos rios e das florestas, dos ribeirinhos e dos caboclos da região, dos territórios e paisagem que mesclam cultura, natureza e comunidade.

Assim, conforme nosso objetivo, o que estamos propondo como matriz de análise geográfica ancorada na relação território-ativo-estratégico (TAE), indica os processos concretos e em potência que podem ser mobilizados como fatores da acumulação do capital nacional e internacional, como frequentemente se verifica nas notícias em jornal referentes às propostas e discursos de privatização da hidrovia Madeira-Amazonas, sob o argumento de que os custos de manutenção estão cada vez elevados; na privatização do aquífero Alter do Chão, dado a discussão global da mercantilização da água, ou mesmo nas propostas de revisão, redução e obliteração das áreas protegidas na Amazônia (Unidades de Conservação, Terras Indígenas e terras das comunidades quilombolas, por exemplo) em discussão no Congresso Nacional, o que significa transformar áreas verdes em espaço das commodities.

Nesse sentido, o que une as áreas de estudos (Porto Velho, Santarém e Belterra), distantes aproximadamente em $1.600 \mathrm{~km}$, é que representam a fronteira, o limite entre a Amazônia das estradas com a Amazônia dos rios e das florestas. Ao Norte dessas áreas localizam-se a massa florestal (Unidades de Conservação), povos indígenas, comunidades ribeirinhas, comunidades quilombolas, espaços que foram intensivamente pressionados pelo capital, mesmo que se registre alguns megaprojetos mineral e hidrelétrico. Portanto, indica-se claramente um limite cartográfico na expansão do capital, que tende a ser transponível nas próximas décadas.

Toda essa questão social e territorial revela as ameaças aos ribeirinhos e aos camponeses extrativistas e se coloca como agenda política central de defesa dos territórios das comunidades amazônicas, que têm no rio-campo-floresta o seu espaço comunitário de reprodução social. 


\section{REFERÊNCIAS}

ALMEIDA, A. W. B. (Org). Conflitos sociais no "Complexo Madeira”. Manaus: Projeto Nova Cartografia Social da Amazônia / UEA Edições, 2009. $391 \mathrm{p}$.

ANEEL. Agência Nacional de Energia Elétrica Brasil. Quadro resumo de compensação financeira pela utilização de recursos hídricos. Disponível em www.aneel.gov.br . Acesso em: 9 de março de 2017.

BARAUNA, G. M. Q. Atingidos por barragens: conflitos socioambientais no Rio Madeira. Manaus-AM, 2014. Tese de doutorado (Doutorado Antropologia Social) - Programa de Pós-Graduação em Antropologia Social, Universidade Federal do Amazonas.

BECKER, B. K. Amazônia: geopolítica na virada do III milênio. Rio de Janeiro: Garamond, 2006. p. 180.

CONCEIÇÃO, F. S. da. A territorialização do capital e a expansão do agronegócio sojeiro: lutas e (re)existências dos camponeses/camponesas das comunidades nova esperança e nova aliança no município de Belterra/Pará. Porto Velho, 2017. 225 f. Dissertação de mestrado. (Mestrado em Geografia) - Programa de Pós-Graduação de Mestrado e Doutorado em Geografia, Universidade Federal de Rondônia.

COSTA SILVA, R. G; CONCEIÇÃO, F. S. da. Crescimento populacional e progresso social em Porto Velho. In: Costa Silva, R. G. (Org.) Porto Velho, urbanização e desafios para uma cidade centenária. 1. ed., Porto Velho: Temática Editora/EDUFRO, 2016. p. 223-248. Disponível em: www.edufro.unir.br. Acesso em: 15 nov. 2017.

COSTA SILVA, R. G; CONCEIÇÃO, F. S. da. Agronegócio e campesinato na Amazônia brasileira: transformações geográficas em duas regiões nos estados de Rondônia e Pará. GEOgraphia, vol. 19, n. 41, p. 107-125, set./dez., 2017. Disponível em: www.geographia. uff.br/index. php/geographia/article/view/1008

COSTA SILVA, R. G. Hidrelétricas do Madeira e a nova geografia de Porto Velho. Tudorondonia.com, Jornal Eletrônico Independente, Porto Velho, p. 1, 23 abr. 2015. Disponível em: www.tudorondonia.com. br/ noticias/hidreletricas-do-madeira-e-a-nova-geografia-de-porto-velho,516 90.shtml . Acesso em: 5 fev. 2017.

SILVA, R. G. Dinâmicas territoriais em Rondônia: conflitos na produção e uso do território no período de 1970/2010. São Paulo, 2010. Tese de doutorado (Doutorado em Geografia Humana) - Programa de Pós-Gra- 
duação em Geografia Humana, Universidade de São Paulo-USP. Disponível em: www.teses.usp.br. Acesso em: 18 mar. 2017.

SILVA, R. G. Da apropriação da terra ao domínio do território: as estratégias do agronegócio na Amazônia brasileira. International Journal of Development Research, 7, (12), 17699-17707, 2017. www.gtga.unir. br/?page_id=679.

FEARNSIDE, P. Hidrelétricas na Amazônia: impactos ambientais e sociais na tomada de decisões sobre grandes obras. Manaus: Editora do INPA, 2015.

IBGE. Instituto Brasileiro de Geografia e Estatística. Divisão urbano-regional (2013). Diretoria de Geociência - Coordenação de Geografia. Disponível em: www.ibge.gov.br. Acesso em: 14 mar. 2017.

IBGE. Instituto Brasileiro de Geografia e Estatística. Sistema IBGE de recuperação automática-SIDRA. Produção Agrícola Municipal 19902014. Disponível em: www.ibge.gov.br. Acesso em: 13 jan. 2016.

LIMA, L. A. P; COSTA SILVA, R. G. A Amazônia como espaço de fronteiras e dos territórios do pessimismo. In: Cury, M. J. F. (Org.). Territórios e territorialidades na Amazônia. 1. ed. Curitiba: CRV, 2017, v. 1, p. 15-38.

LIMA, K. F. et. all. A comercialização do pescado no município de Santarém, Pará. Revista Brasileira Engenharia de Pesca, 9(2): p. 1-9, 2016. Disponível em: http://ppg.revistas.uema.br/index.php/REPESCA/ article/view/988. Acesso em: 20 jan. 2018.

PNCSA. Projeto Nova Cartografia Social da Amazônia. Fascículo NR. 19. Vila Jirau: ribeirinhos, extrativistas e moradores das comunidades deslocadas por hidrelétricas, Rio Madeira-RO. In: Nova Cartografia Social da Amazônia. Série Mapeamento Social como instrumento de gestão territorial contra o desmatamento e a devastação, 2014.

PNMA. Programa Nacional de Meio Ambiente. Os Ecossistemas brasileiros e os principais macrovetores de desenvolvimento: subsídios ao planejamento da gestão ambiental. Ministério do Meio Ambiente, dos Recursos Hídricos e da Amazônia Legal, Secretaria de Coordenação dos Assuntos do Meio Ambiente. Brasília: MMA, 1995.

PORTO-GONÇALVES, C. W. Amazônia, Amazônias. 2. ed. São Paulo: Contexto, 2008. 184 p.

PREFEITURA MUNICIPAL DE BELTERRA. Diagnóstico Socioeconômico de Belterra. Belterra/PA: Gráfica e Editora Tiagão, 2010. Disponibilizado em outubro de 2016. 
RIBEIRO, A. F. A.; FRANCA, R. R. A cheia histórica do rio Madeira e seus impactos no espaço agrário do município de Porto Velho. In: SILVA, R. G. C. (Org.) Porto Velho Cultura, Natureza e Território. 1. ed. Porto Velho: Edufro/Temática Editora, 2016. p. 148-161.

RAFFESTIN, C. A produção das estruturas territoriais e sua representação. In: Saquet, M. A; Sposito, E. S. (Orgs.) Territórios e territorialidades: teorias, processo e conflitos. 2. ed., Rio de Janeiro: Consequência Editora, 2015. 368 p.

SANTOS, M. A natureza do espaço: técnica e tempo, razão e emoção. São Paulo: Hucitec, 1996. 308 p.

SAQUET, M. A. Por uma geografia das territorialidades e das temporalidades: uma concepção multidimensional voltada para a cooperação e para o desenvolvimento territorial. 2 ed., Rio de Janeiro: Consequência, 2015. 162 p.

SEVÁ, Oswaldo. Estranhas catedrais. Notas sobre o capital hidrelétrico, a natureza e a sociedade. Cienc. Cult., São Paulo, v. 60, n. 3, p. 44-50, Set. 2008. Disponível em: http://cienciaecultura.bvs.br/scielo.php ?script=sci_arttext $\&$ pid $=$ S0009-67252008000300014\&lng=en $\& n r m=$ iso. Acesso em: 15 fev. 2018.

TIZUKA, M. M. Geoarqueologia e paleoidrologia da planície aluvial holocênica do Alto Rio Madeira entre Porto Velho e Abunã-RO. Rio Claro-São Paulo, 2013. Dissertação de mestrado (Mestrado Geociências e Meio Ambiente) - Instituto de Geociências e Ciências Exatas do Campus de Rio Claro, da Universidade Estadual Paulista Júlio de Mesquita Filho.

TRINDADE JÚNIOR, S. C. et. al. Espacialidades e temporalidades urbanas na Amazônia ribeirinha: mudanças e permanências a jusante do rio Tocantins. ACTA Geográfica, Ed. Esp. Cidades na Amazônia Brasileira, p. 117-133, 2011.

VALBUENA, R. Santarém, entre la Amazonia de los ríos y la Amazonia de las carreteras. Confins [En ligne], 3 | 2008, mis en ligne le 24 avril 2008. Disponível em: http://journals.openedition.org/confins/3903. Acesso em: $1^{\circ}$ abr. 2016.

VALBUENA, R. Les dynamiques territoriales associées au soja et les changements fonctionnels en Amazonie. Le cas de la région de Santarém, Pará, Brésil. Confins [En ligne], 5 | 2009, mis en ligne le 21 mars 2009. Disponível em: http://journals.openedition.org/confins/5615. Acesso em: 15 fev. 2018. 


\section{Agronegócio e CAMPesinato na Amazônia brasileira: \\ TRANSFORMAÇÕES GEOGRÁFICAS EM DUAS REGIÕES NOS estados de Rondônia e Pará ${ }^{1}$}

Ricardo Gilson da Costa Silva" Francilene Sales da Conceição**

\section{INTRODUÇÃO}

$\mathrm{Na}$ Amazônia brasileira o agronegócio representa a cristalização dos espaços da globalização (Santos, 2005), cuja trama socioespacial opõe o campesinato e as forças hegemônicas do capital que transformam a agropecuária regional e, por conseguinte, o uso do território. Esse processo instaura um conjunto de transformações geográficas que (re)significam a região na divisão territorial do trabalho, manifestando "manhas" do meio técnico-científico-informacional que definitivamente impõe fragmentações no espaço regional, principalmente quando estes se abrem aos fluxos globais (Santos, 1996; Silva, 2014b, 2015; Bernardes, 2010).

O campesinato, que entendemos como classe social e modo de vida (Oliveira, 1991), em seus respectivos territórios, é pressionado pelos mecanismos coercitivos impostos pelas forças hegemônicas do capital, ancorado na modernização regional através do agronegócio da soja. Tal situação geográfica deve ser entendida como um processo multiescalar, de conversão dos espaços agrícolas da produção familiar em campo de expansão econômica do capital globalizado, que adicionado à produção

\footnotetext{
${ }^{1}$ Artigo publicado em: COSTA SILVA, R. G.; CONCEICAO, F. S. Agronegócio e campesinato na Amazônia brasileira: transformações geográficas em duas regiões nos estados de Rondônia e Pará. Geographia (UFF), v. 19, p. 54-72, 2017.

" https://orcid.org/0000-0002-3348-9629

"* https://orcid.org/0000-0002-3401-326X
} 
de commodities agrícolas se configura em espaços da globalização. Algumas regiões periféricas que apresentavam pouco dinamismo econômico, sob a ótica do capital, passaram a receber investimentos das grandes empresas globalizadas, transformando o espaço regional a partir de novas verticalidades (Santos, 1996), o que ampliou as relações local e global. Essa é a situação que atualmente se configura nos municípios de Vilhena (localizado no sul de Rondônia), Santarém e Belterra (localizados no oeste do Pará), ambos marcados pelo avanço da produção de soja (Figura 1), e objeto desta análise.

Figura 1 - Geografia da produção de soja na Amazônia (2013). Localização dos municípios de Vilhena (RO), Belterra e Santarém (PA).

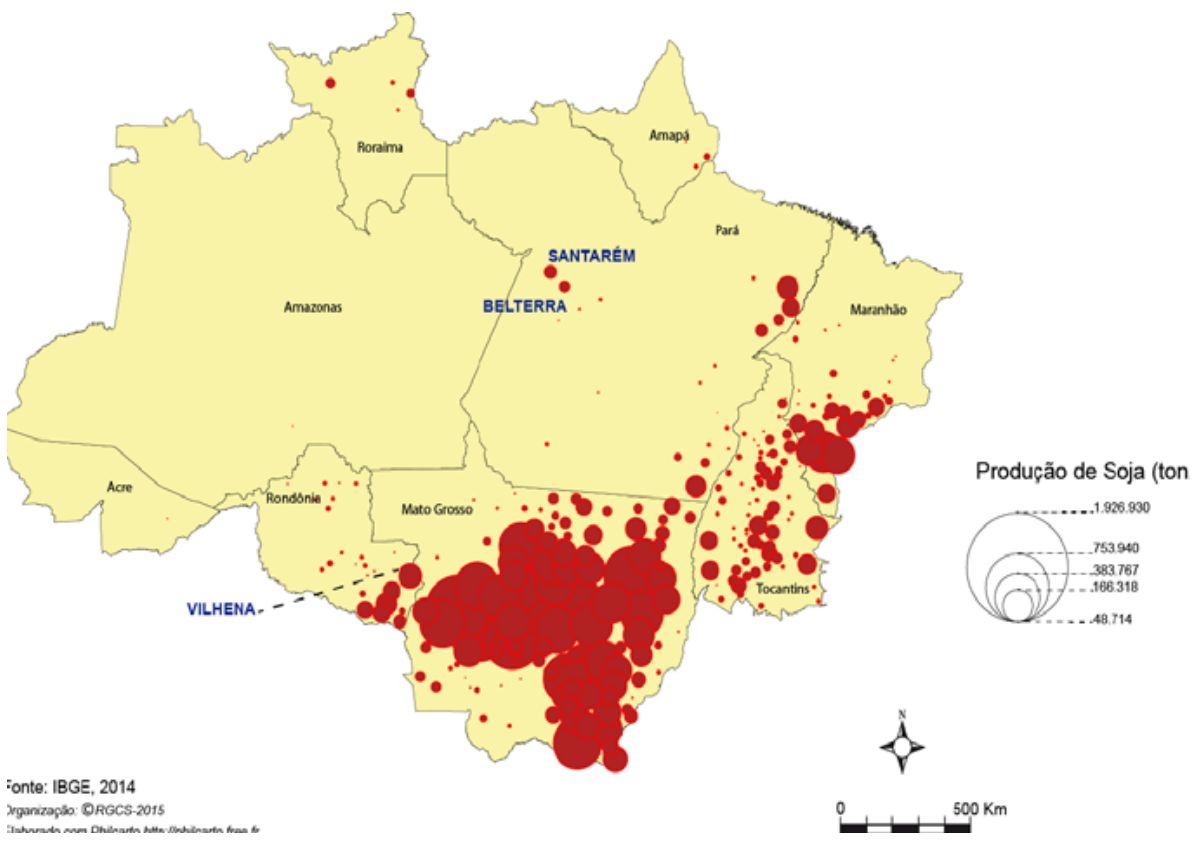

Fonte: IBGE, 2014.

Em específico, a análise do agronegócio se torna relevante pelas transformações regionais que se instauraram nos lugares, considerando a formação socioespacial onde a presença do campesinato se cristalizou em função do processo de colonização agrícola. Nos municípios objeto deste texto, a soja comparece como elemento de reestruturação produti- 


\section{Geografia, território e sociedade na Amazônia}

va no espaço regional, criando verticalidades pelo capital global. A presença de grandes empresas, como Cargill, Amaggi, Bunge, entre outras, criam solidariedades organizacionais do capital (Santos. Silveira, 2005), fragmentando o espaço regional em áreas de modernização da agricultura que se globaliza e, concomitantemente, expropria o campesinato.

Constatam-se transformações no espaço agrário estimuladas pelo capital globalizado, instaurando crises no uso do território, quando o espaço do campesinato diminui e o espaço do agronegócio avança. O entendimento do movimento do capital se realizando no ambiente local/ regional a partir da produção de mercadorias e de domínio do território nos indica os arranjos espaciais emergentes que atravessam as regiões, sendo, pois, comandados de diferentes lugares, cujas hierarquias políticas, técnicas e informacionais se manifestam conflituosamente no espaço da produção.

Nesse sentido, o texto analisa essas dinâmicas territoriais a partir das contradições que opõem o campesinato e as comunidades tradicionais amazônicas frente ao capital do agronegócio em sub-regiões amazônicas, demonstrando as fragmentações produzidas pelo processo de globalização que atinge o espaço regional (Figura 1). Os camponeses e as comunidades tradicionais amazônicas, conceito expresso no universo da relação social entre ser humano/comunidades, natureza e território, categorizadas como ribeirinhos, pescadores, seringueiros, quilombolas, povos indígenas, dentre outros, esboçam em suas lutas e vivências os tensionamentos elaborados no processo de produção do espaço como totalidade histórica (Santos. 1998, 1996 e 2005), cujos desdobramentos concretos delineiam a formação dos territórios camponeses/comunidades frente ao território do agronegócio. Cristaliza-se a relevância da análise por verificar as mudanças na agricultura camponesa local em área de commodity, em que as monoculturas do agronegócio tendem a expulsar, pelo processo de expropriação e de coerção territorial do capital, as populações camponesas e as comunidades tradicionais amazônicas, representando uma nova fase de modernização conservadora no espaço agrário amazônico (Porto-Gonçalves, 2001).

\section{GeOgRAFIA do AGRONEgócio SOJEIRO EM RoNDÔNIA}

As atuais metamorfoses territoriais no estado de Rondônia derivam do processo de colonização agrícola iniciado a partir de 1970, sob a gestão do Estado brasileiro, através do Instituto Nacional de Colonização e Reforma Agrária (Incra), no qual foi sendo produzido um espaço substantivado pelas relações sociais de produção ancorada na extração 


\section{Agronegócio e campesinato na Amazônia brasileira}

madeireira e, principalmente, na agropecuária (Théry, 1976, 2012; Valverde, 1979; Silva, 2012).

Esse período inaugura na Amazônia um novo meio geográfico - o meio técnico - onde, em larga escala, a floresta foi continuamente substituída pela expansão da agropecuária, designando na região a produção de mercadorias resultado das modificações econômicas na divisão territorial do trabalho, cujo espaço agrário modificado potencializa a transformação do espaço regional.

Na geografia de Rondônia, antes da colonização agrícola, o capital e o trabalho se realizavam através do extrativismo vegetal, potencializado na extração da castanha do Brasil, pescado, borracha, frutas e caça. Nesse período, o extrativismo mineral (extração da cassiterita) já havia penetrado a floresta, sobretudo na região do município de Porto Velho, mas, todavia, sem impor mudanças significativas na geografia regional (Théry, 1976, 2012). Isso significa que os capitais comercial e extrativista não criaram e não materializaram objetos técnicos que pudessem ampliar a composição técnica do espaço local, ou seja, as formas-conteúdo geográficas que ensejassem dinâmicas sociais e econômicas favoráveis à expansão/reprodução do capital. A configuração geográfica se restringia ao modelo ferroviário-fluvial, e somente a partir da colonização agrícola o campesinato migrante desenvolve a agropecuária, expandindo o processo produtivo através de dezenas de assentamentos rurais, médias e grandes fazendas, tornando o espaço local (meio técnico) mais poroso às dinâmicas regional e nacional (Silva, 2015).

Esse processo avança até 1997, quando a geografia da Amazônia é permeada pela produção de novas mercadorias que representará, nos anos subsequentes, a cristalização do que Santos (2005) qualificou de Espaços da Globalização. A empiricização do mundo globalizado se manifestou em Rondônia a partir da produção de soja, que pressionada pela densidade dessa commodity no estado do Mato Grosso, ensejou a expansão agrícola para as bordas da floresta amazônica, localizada no sul de Rondônia e no oeste do Pará (conforme Figura 1). No caso de Rondônia, a inauguração de um novo sistema de objeto - a Hidrovia Madeira-Amazonas - sinalizou aos agentes econômicos do agronegócio (produtores de soja, empresas de insumos e tradings agrícolas) a possibilidade de reprodução do capital, inclusive em áreas de forte presença camponesa, a partir da aquisição e do arrendamento de terras, fazendo um uso corporativo do território (Santos; Silveira, 2005; Silva, 2015, 2014a, 2014b). 
A geografia do agronegócio da soja se consolidou no sul rondoniense, centralizada pelo município de Vilhena, o maior produtor de soja e milho do estado (Figura 2). Vilhena se caracteriza por ser uma cidade do agronegócio e configura o que Elias (2012) qualificou de região produtiva agrícola, na medida em que reúne as articulações do espaço agrário e espaço urbano como híbridos dos processos mercantis da produção de soja, sendo um espaço cada vez mais aberto aos comandos e fluxos externos, onde a solidariedade organizacional (Santos; Silveira, 2005) - conceito entendido como o processo de controle espacial do capital hegemônico a partir das determinações técnica e normativa da mercadoria, em que os produtores ficam obrigados a se vincular às redes que adicionam valor ao espaço produtivo - assume os mecanismos do capital hegemônico a partir da formação dos circuitos espaciais da produção e seus respectivos círculos de cooperação (Santos, 1988).

Figura 2 - Regionalização da soja em Rondônia (2014).

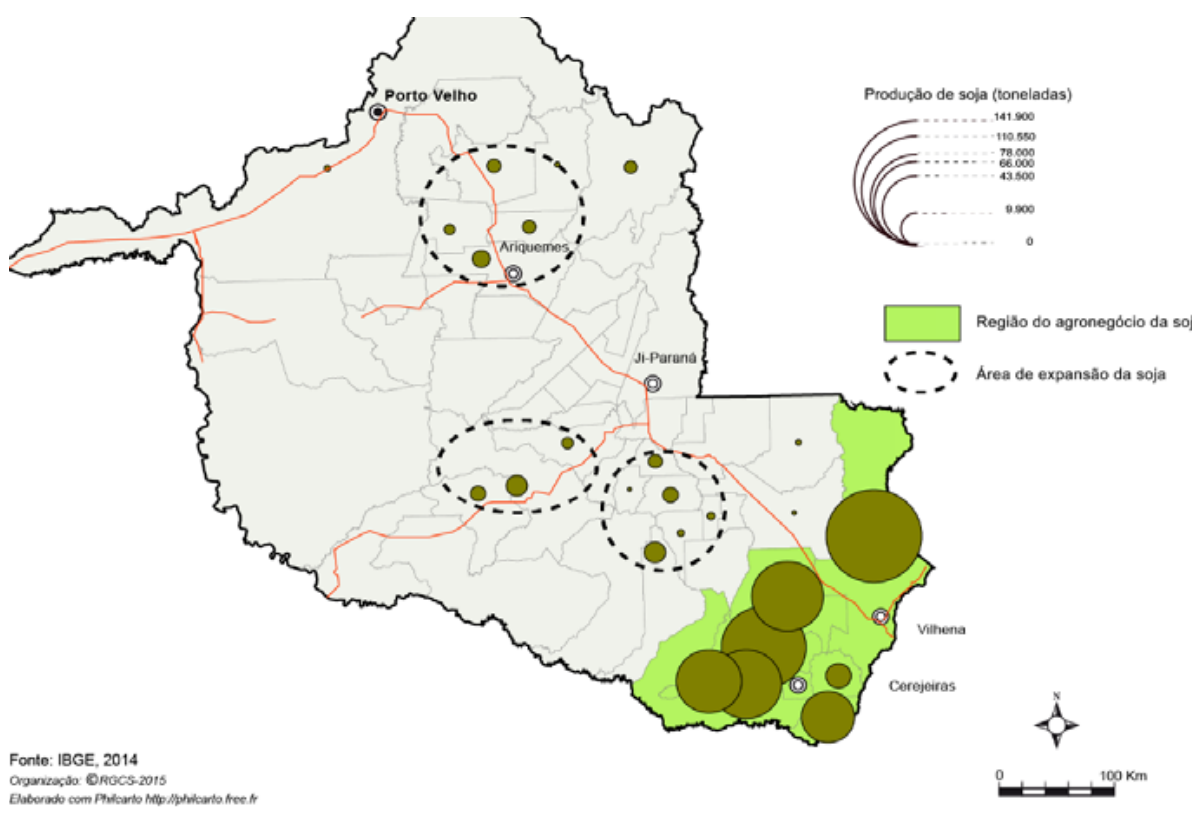

Fonte: IBGE, 2014.

Com a Hidrovia do Madeira, a expansão da soja (Figura 3) cresceu das míseras 1.296 toneladas e 656 hectares em 1997 para 


\section{Agronegócio e campesinato na Amazônia brasileira}

614.678 toneladas e 195.180 hectares em 2014, multiplicando em 474 vezes a produção e 298 vezes a área. Considerando que o município de Vilhena se caracterizava por apresentar grandes propriedades com produção de pecuária bovina de corte, instaura em Rondônia a primeira particularidade regional vinculada ao mercado externo: a regionalização da soja e a especialização territorial da pecuária permite a fragmentação do espaço regional (Silva, 2014a, 2014b). Qualifica-se essa dinâmica territorial quando se verifica que na composição da estrutura fundiária de Vilhena a diferença média de área entre a agricultura não familiar (normalmente agricultura capitalista) e a agricultura familiar é de 20 vezes, superando em $100 \%$ a média estadual (10 vezes), conforme dados do Censo Agropecuário (IBGE, 2006).

Figura 3 - Evolução da produção de soja em Rondônia (1990/2014).

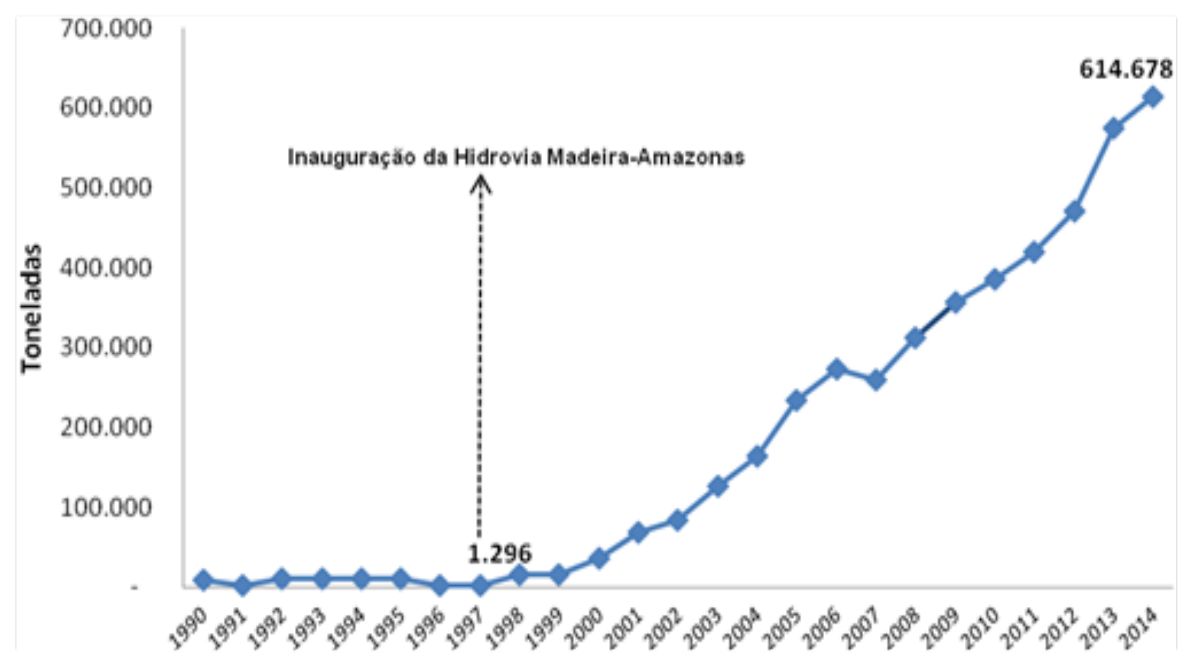

Fonte: IBGE, 2015 - Produção Agrícola Municipal. Org.: Autores.

Alguns dados econômicos e sociais qualificam esse processo no município de Vilhena: apresentou 95\% de taxa de urbanização (a maior de Rondônia); representou 35,31\% das exportações (carnes e soja) de Rondônia em 2014 ( $1^{\circ}$ lugar); produziu $23 \%$ dos grãos de soja, milho e arroz (2013) e centralizou a produção dos demais municípios, com a presença do capital hegemônico (JBS, Bunge, Cargill e Amaggi). A centralidade de Vilhena impõe a formação da região do agronegócio da 


\section{Geografia, território e sociedade na Amazônia}

soja (conforme Figura 2), formada por sete municípios, que no conjunto representam $79 \%$ da produção de grãos (arroz $32 \%$, milho $79 \%$ e soja 89\%) em Rondônia (IBGE, 2015).

Resultam desse processo dois efeitos geográficos na região do agronegócio. Primeiro, os municípios com forte presença do campesinato sofreram processo de migração campo-cidade e campo-campo. $\mathrm{Na}$ primeira situação, a população rural, em geral formada por famílias camponesas, migrou para as cidades, o que se pode constatar no aumento da taxa de crescimento urbano em Rondônia e na região do agronegócio. No período intercensitário (2000-2010) a população estadual cresceu $13 \%$, a urbana $29 \%$ e a rural decresceu em $-16 \%$. Na região do agronegócio esses dados representam, respectivamente, 15\%, 25\% e -15\%, sendo seu maior impacto nos pequenos municípios caracterizados pela maior presença de famílias camponesas. Dos sete municípios que formam a região do agronegócio, em cinco a população rural decresceu no período censitário, cujas taxas negativas variaram de $-9 \%$ a $-33 \%$ (IBGE, 2010).

Certamente esses dados também resultam do aumento do preço da terra derivado da pressão do agronegócio, que se traduz no processo de coerção territorial. Nos municípios em que a população rural aumentou, isso se deve à luta dos movimentos sociais que obrigou o Governo Federal a criar novos assentamentos rurais, em que muitos destes são resultados dos conflitos agrários com fazendeiros e sojicultores. Na segunda situação, o fenômeno da migração intra-estadual se acentuou, sobretudo, nas sub-regiões de fronteira e da recente expansão agropecuária, formada por pequenos municípios onde se localizam áreas públicas que se tornaram objeto de ocupação irregular, grilagem e invasão de terras públicas, com pressão socioterritorial em Unidades de Conservação e Terras Indígenas (Silva, 2016b).

A modernização conservadora da agricultura conduzida pelos agentes hegemônicos do agronegócio ampliou os conflitos agrários em Rondônia. Segundo os dados do Relatório Anual dos Conflitos no Campo 2014 organizado pela Comissão Pastoral da Terra (CPT), Vilhena foi o município do sul de Rondônia que mais apresentou conflitos agrários. Foram registrados conflitos envolvendo 206 famílias de sem-terra, 445 famílias de posseiros, 75 famílias de ocupantes e 224 famílias de assentados, somando um total de 950 famílias camponesas envolvidas, tendo como causa principal as forças do agronegócio da soja (CPT, 2014, 2016). 


\section{Agronegócio e campesinato na Amazônia brasileira}

Ressaltamos que Rondônia apresentou um total de 2.977 famílias camponesas envolvidas em conflitos, e o município de Vilhena concentrou $31,9 \%$ deste número. Os fatores que acentuaram os conflitos agrários decorrem da saturação das áreas de plantio de grãos, o que fez aumentar a pressão para a incorporação de terras camponesas ao processo produtivo do agronegócio (Ribeiro; Silva; Correa, 2015). $\mathrm{Na}$ região, o campesinato vivencia dias de grande pressão socioterritorial, na medida em que o agronegócio se coloca como modelo produtivo único centralizado nas médias e grandes propriedades, cuja agenda territorial e política busca obliterar e mesmo anular a produção e a presença social do campesinato. Contudo, as resistências camponesas emergem nas lutas pela terra, que se traduzem em novos assentamentos rurais na região do agronegócio, indicando novas territorializações do campesinato.

O Assentamento Águas Claras, localizado no município de Vilhena, é o que mais sofre as pressões do agronegócio, sobretudo em função da dimensão ambiental e territorial. Cercado pelo território do agronegócio, as propriedades camponesas (Figura 4) são impactadas pelos agrotóxicos lançados dos aviões que pulverizam as monoculturas de soja e milho, debilitando a saúde das famílias do assentamento e impactando seus produtos agrícolas. O crime ambiental foi objeto de denúncia dos assentados junto ao Poder Judiciário local, mas que não resultou em medidas eficientes e satisfatórias para os camponeses. A pressão territorial, para além da questão ambiental, avança a partir do litígio das terras ocupadas pelo campesinato. Dessa forma, a constante insegurança que assola o cotidiano das famílias no assentamento se deve às ameaças de morte e intimidação política que, segundo as lideranças, são oriundas dos fazendeiros da soja (Ribeiro; Silva; Correa, 2015, p. 16-17). 
Figura 4 - Trabalho da mulher camponesa no Assentamento Águas Claras, município de Vilhena (2015).

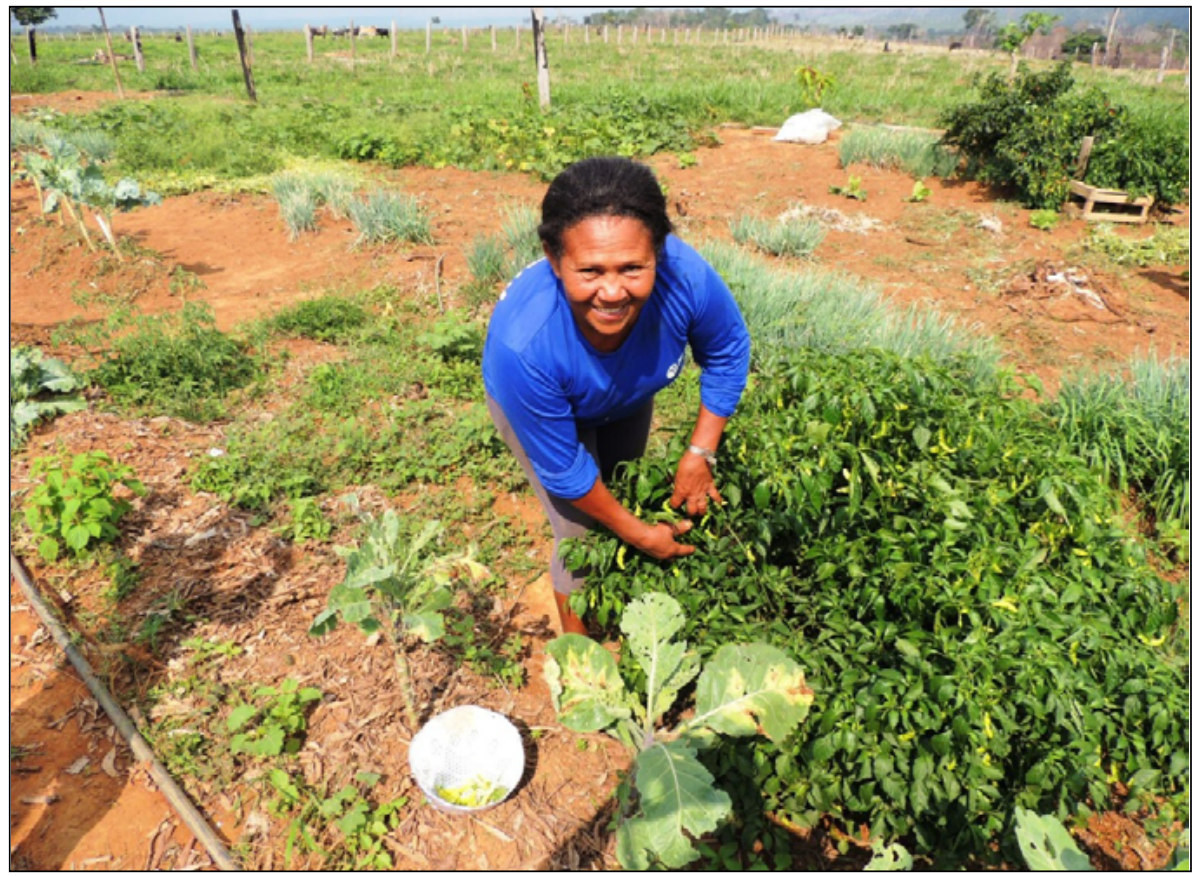

Fonte: Trabalho de Campo, 2015. Foto: Autores.

Os camponeses se encontram intimidados pelos sojicultores, temem revidar contra aqueles que detêm o poder econômico-político e sofrer possíveis represálias desse modelo territorial excludente e contraditório, por isso acabam sofrendo pressões de todos os lados (instituições públicas, pistoleiros/jagunços, fazendeiros, Poder Judiciário). Sem alternativas de combater essa problemática avassaladora do agronegócio, sofrem impactos diretos nas suas pequenas propriedades, ora ambiental, ora social. Os produtores de soja, ao passarem o dessecante e/ou outros fertilizantes (agrotóxicos) nocivos à saúde humana, às plantas e outros vegetais nativos, com a ação dos ventos, deslocam para o interior das propriedades camponesas elementos tóxicos que destroem e eliminam as variedades de cultivos agrícolas, cuja finalidade é a manutenção da subsistência familiar e a comercialização de produtos no comércio local. 


\section{Agronegócio e campesinato na Amazônia brasileira}

As coerções territoriais se agravam nesse cenário, que de um lado tem o território do agronegócio tentando ampliar suas áreas de influência e manter seu sistema hegemônico dominador, e do outro tem o território do campesinato que busca a todo custo resistir contra as forças do capital globalizado e continuar desenvolvendo a policultura a sua maneira por meio do trabalho familiar. Diante dessas emblemáticas disputas territoriais, destaca-se que a concentração fundiária é cada vez mais frequente no território do agronegócio, estimulando a supervalorização do preço das terras destinadas à produção de commodities.

A expansão agrícola fez com que o preço das terras na Amazônia aumentasse, ampliando os conflitos agrários nas áreas ocupadas pelos camponeses. Diversas áreas foram reivindicadas pelos fazendeiros, cujas propriedades se ancoram em títulos públicos "duvidosos" ou pelas famosas CATPs ${ }^{2}$ (Contrato de Alienação de Terra Pública) - que são questionadas pelo campesinato e pelo Incra/Programa Terra Legal. Contudo, o campo de disputa política se deslocou para o Judiciário, ambiente institucional favorável ao latifúndio e prejudicial às pautas camponesas.

Nesse cenário, o campesinato em Vilhena e no sul de Rondônia experimenta as pressões da reestruturação produtiva no campo, as pressões políticas e territoriais das forças do agronegócio, que se colocam ideologicamente como modelo e caminho único de crescimento econômico e desenvolvimento social.

\section{Geografia do agronegócio sojeiro no oeste do Pará}

Formado principalmente pelos rios Amazonas, Trombetas e Tapajós, o oeste do estado do Pará se caracteriza por ser uma sub-região onde tempo-espaço é configurado pela presença dos rios na vida comunitária, pela exuberante massa florestal e rica vida silvestre, interligando centenas de comunidades ribeirinhas, que se formaram ao longo das margens dos rios e igarapés, às cidades locais.

\footnotetext{
${ }_{2}^{2}$ Título precário, emitido na década de 1980, com a finalidade de incentivar o povoamento e a produção agropecuária da Região Norte. Caracteriza-se por um contrato firmado pelo Incra, que autoriza a ocupação regular. Tem validade mediante o cumprimento das cláusulas resolutivas tais como: prever a obrigação de ocupar a terra, dar a função social ao imóvel, além da proibição de venda a terceiros. Assim, não cumpridos quaisquer desses compromissos, o contrato seria desfeito e o Incra poderia retomar a área (Ribeiro; Silva; Correa, 2015).
} 


\section{Geografia, território e sociedade na Amazônia}

Cidades ribeirinhas (Trindade Jr.; Silva; Amaral, 2008) constitui a categoria de análise que melhor expressa a organização espacial nessa região da Amazônia brasileira, também denominada de Baixo Amazonas. A principal cidade é Santarém, localizada no encontro do rio Tapajós com o Amazonas, que exerce centralidade administrativa, econômica, política e cultural na região do Baixo Amazonas. Localizada nas margens do rio Trombetas, outra cidade importante é Oriximiná, conhecida pela extração de bauxita em áreas que outrora eram das comunidades quilombolas. O acesso a Oriximiná, a partir de Santarém, só pode ser feito através dos rios Amazonas e Trombetas, cujo percurso demora cerca de 9 horas em barco de transporte comercial. Projetos minerais e hidrelétricos e a resistência quilombola compõem a geografia dialética na região do Trombetas. Mais próxima de Santarém $(50 \mathrm{~km}$ de distância) está a cidade de Belterra, localizada em região de planalto, às margens da rodovia BR-163 (Cuiabá-Santarém).

Outrora, as famílias que viviam nas comunidades do planalto santareno (que abrange áreas dos municípios de Santarém e Belterra) tinham sua cultura baseada na agricultura, no extrativismo sustentável e na caça como forma de garantir a subsistência familiar. No trabalho utilizavam técnicas artesanais, trocavam dias de serviços nas propriedades dos vizinhos, compartilhavam alimentos e outros produtos agrícolas, faziam mutirões e programavam as festividades religiosas dos santos padroeiros das comunidades. De certo modo, obedeciam ao tempo da natureza para derrubar, plantar, produzir e colher, pois através do trabalho coletivo faziam seus roçados e plantavam variados produtos agrícolas (arroz, feijão, milho, mandioca, macaxeira) e outros agro cultivadores como legumes, hortaliças e frutas, além da criação de animais (Conceição, 2017).

A safra obtida da agricultura era anual, porque dependia do ritmo do "inverno" amazônico, caracterizado por regime de intensa pluviosidade. Aguardar o período das chuvas para "molhar" a terra e, consequentemente, as plantações, se tornava necessário para que os camponeses obtivessem uma produção agrícola significativa. As mercadorias agrícolas, além de servir ao consumo familiar, destinavamse ao abastecimento dos mercados local e regional. Utilizavam o sistema corte-queima, a policultura e a rotação de culturas. Esse sistema se baseava no uso da terra e da floresta, caracterizando uma nova tipologia de campesinato, com um perfil agroextrativista. 


\section{Agronegócio e campesinato na Amazônia brasileira}

As práticas das policulturas garantiam renda e a manutenção da soberania alimentar ${ }^{3}$ das famílias camponesas (Figura 5). Além de realizar a agricultura, a extração de produtos da floresta também constituía um fator predominante. Coletavam sementes e frutos de andiroba, castanha-do-pará, cumaru, pequiá, oxí, maracujá-do-mato, jenipapo, pajurá, mucajá ou macaúba, tucumã, abacaba etc., e extraíam óleo de copaíba e leite da sucuuba, produtos da floresta que ajudavam na qualidade de vida e de grande aceitação no comércio local, permitindo-lhes auferir renda monetária derivada do extrativismo. Mesmo com grande variabilidade de espécies, as famílias camponesas plantavam seus remédios medicinais nos quintais de suas casas, a fim de combater as doenças na família ou na vizinhança, caracterizando um regime baseado em relações de proximidade e de saberes tradicionais (Conceição, 2017).

\footnotetext{
${ }^{3}$ Este é um conceito utilizado pelas populações camponesas para se referirem a seu respectivo modo de vida: tem a ver com uma produção autônoma, diversificada (cultivo de vários produtos agrícolas), saudável, que garante a subsistência da família e de toda a comunidade, além de exercer o direito do campesinato em respeitar o meio ambiente, devendo os mesmos manterem a preservação e a conservação dos recursos naturais. Contrasta, portanto, com o conceito de segurança alimentar, entendido simplificadamente como a capacidade de adquirir alimentos - uma perspectiva econômica neoclássica - sem necessariamente preocupar-se com a forma e o local onde é produzido o alimento. A soberania alimentar é mais ampla e se relaciona com a vida humana, almejando um ambiente ecologicamente equilibrado e socialmente justo e sustentável (Mcmichel, 2016).
} 
Figura 5 - Camponês preparando a terra para plantar feijão em Belterra (2016).

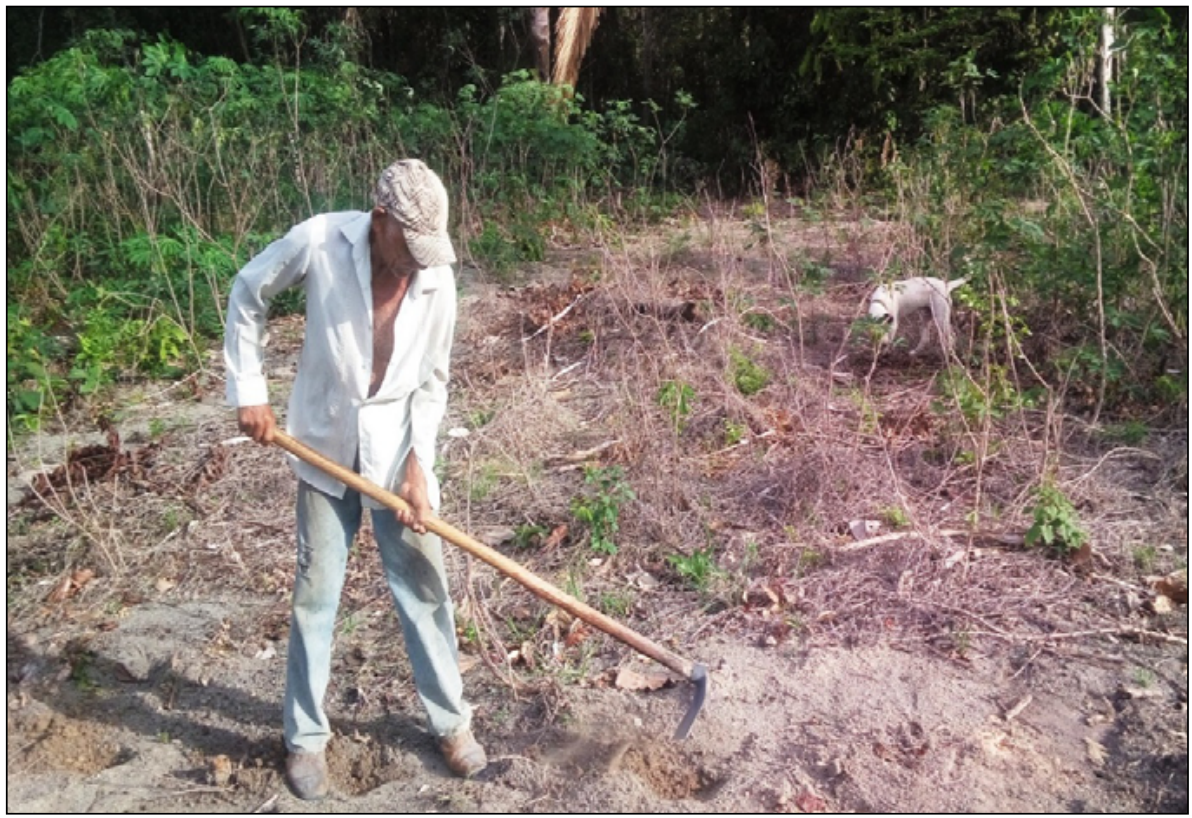

Fonte: Trabalho de Campo, 2016. Foto: Francilene Sales Conceição.

Quando a maioria das comunidades rurais não tinha energia elétrica, utilizavam lamparina, lampião ou velas para não permanecer no escuro. Como técnica de conservação dos alimentos (principalmente carnes e peixes), salgavam ou secavam ao sol, definindo a durabilidade máxima para serem consumidos em duas semanas. A água ingerida era natural e os depósitos de armazenamento da água eram os potes ou os filtros. Para o campesinato a natureza condicionava suas ações e seu trabalho, determinando a produção dos alimentos (Oliveira, 1991). Os camponeses somente se deslocavam à cidade esporadicamente, porque tinha quase tudo de que necessitavam para seu consumo nas propriedades onde viviam. Da cidade precisavam comprar alguns gêneros alimentícios, ferramentas de trabalho ou comercializavam seus produtos agrícolas nas feiras dos municípios de Santarém e Belterra.

Algumas comunidades enfrentavam o problema da água na região de planalto, onde o nível do lençol freático é profundo e as condições financeiras das famílias camponesas não lhes permitiam construir poços artesianos. Portanto, a escassez hídrica obrigava as famílias a fazerem uso de alguns reservatórios que surgiam espontaneamente 


\section{Agronegócio e campesinato na Amazônia brasileira}

(pequenas "poças"), coletando águas das chuvas, utilizando "bicas" para depositar água em cisternas ou tanques. A problemática enfrentada por essas famílias decorre das ineficientes políticas públicas, que ainda são perceptíveis em algumas comunidades rurais. Atualmente, em Belterra, as famílias residentes no planalto são atendidas por um "carro-pipa", sendo a "alternativa" adotada pela Prefeitura Municipal para atender a população com o abastecimento d'água. Assim, mesmo localizados na maior bacia hidrográfica do mundo, há comunidades com dificuldades de acesso à água, o que contribui indiretamente com a migração da população rural para a cidade. Em período recente, a divisão social do trabalho caracterizava-se na figura do pai - representado como o "chefe da família" -, da mãe e dos filhos e outros parentes. Juntos, formavam a unidade familiar do campesinato baseada na indissociabilidade terra, natureza, família e trabalho.

Todavia, no espaço agrário a economia globalizada pauta-se pela produção de commodities, buscando disputar áreas consolidadas, sobretudo, pelo campesinato. Segundo Schlesinger e Noronha (2006), no Pará, o cultivo dos grãos de soja e a incorporação do agronegócio ao mercado agroexportador alavancou a partir do ano de 1997, destacando os municípios de Paragominas e Ulianópolis, no nordeste paraense e em 1998 essa cultura agrícola se expande para os municípios de Redenção e Conceição do Araguaia, no sul do Estado. Nesse período a soja começou a ser inserida nos municípios de Santarém e Belterra, oeste do Pará. A ressignificação da rodovia BR-163 em 1997, como eixo de transporte emergente da soja, abriu a região do Baixo Amazonas ao fluxo da globalização, ampliando os grãos de soja em áreas então sob domínio do campesinato e das comunidades tradicionais amazônicas.

\footnotetext{
${ }^{4}$ É uma calha onde a água proveniente do processo de precipitação cai sobre esse objeto e percorre até completar todo seu o trajeto, local que será depositado o líquido em um recipiente. $\mathrm{Na}$ Amazônia é muito comum as famílias utilizarem nas suas residências, podendo ser feito de troncos de árvores ou de canos.
} 
Figura 6: - Produção de soja nos municípios de Santarém e Belterra (1997-2014).

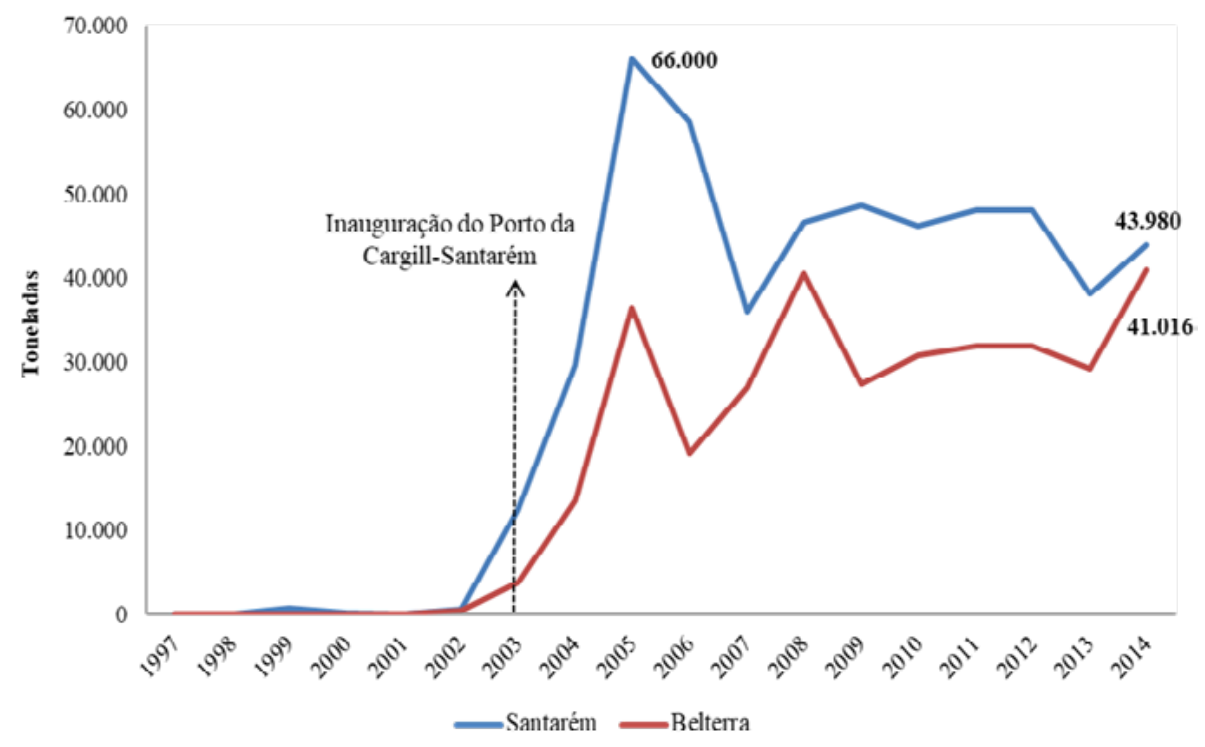

Fonte: IBGE, 2015. Org.: Autores.

Tanto para Rondônia quanto para a região do Baixo Amazonas, o ano de 1997 indica a virada espacial do agronegócio em áreas com forte presença camponesa. Em Santarém a produção iniciou com 107 toneladas, atingindo 66.000 toneladas em 2005, e reduzindo a 43.980 toneladas em 2014. Para Belterra, o início demorou mais um pouco, aparecendo a primeira colheita em 2002, com produção de 450 toneladas de soja. A fase experimental se mostrou muito positiva aos sojeiros, que ampliaram significativamente a produção agrícola, saltando de 3.780 toneladas, em 2003, para 13.500 toneladas em 2004; 36.450 toneladas em 2005 e 40.500 toneladas em 2008, mantendo aproximadamente esses números nos dias atuais (Figura 6). As culturas de arroz e milho foram utilizadas para "amansar" a terra, que serviriam, posteriormente, ao plantio da soja. Em Belterra a produção de soja aumentou espantosamente, atingindo áreas urbanas, tornando-se uma particularidade emergente na paisagem da cidade.

Toda essa geografia emergente é resultado da construção estratégica do terminal graneleiro da Cargill, localizado às margens do rio Tapajós, em Santarém (Figura 7). A partir do ano 2000 se intensificou 


\section{Agronegócio e campesinato na Amazônia brasileira}

a movimentação de cargas e transportes na rodovia BR-163 (Cuiabá-Santarém) e contribuiu com o aumento dos grãos nos municípios de Santarém, Belterra e Mojuí dos Campos, que estão sob a influência dessa rodovia. Tanto o porto da Cargill como a pavimentação da rodovia constituem sistemas de engenharias ${ }^{5}$ (Santos, 1998, 1996 e 2005) de tamanha complexidade que modificaram, sobremaneira, a geografia local, dado que os novos objetos técnicos surgiram na paisagem ribeirinha de Santarém e da agricultura camponesa de Belterra, construindo um novo significado ao lugar, mas também tornando-se objetos estranhos à história local. Isso ampliou a escala geográfica da relação social, dos espaços rural e urbano, onde os fluxos das commodities articularam o local com o global, aproximando o mundo ao lugar e ao território.

A instalação do capital mostra que o agronegócio exige cada vez maiores investimentos em seus projetos hegemônicos. A presença desse sistema de objeto (terminal portuário) na foz do Tapajós modificou os aspectos estrutural e funcional do espaço regional. Nesse contexto, o capital hegemônico transformou o espaço local em um sistema agroexportador bem expressivo no cenário regional, cujo objetivo é acelerar a fluidez territorial (Arroyo, 2001) na Amazônia, garantindo o fluxo da mercadoria em escala internacional.

\footnotetext{
${ }^{5}$ Esse conceito foi desenvolvido por Milton Santos para se referir a um conjunto de objetos técnicos ou fixos criados no espaço geográfico, deixando a natureza mais artificial/técnica o que leva a causar estranhamentos para determinados grupos sociais. Os sistemas de engenharias correspondem ao conjunto de elementos fixos que podem ampliar os fluxos em diversas escalas geográficas, no qual os lugares se tornam mais conectados ao mundo.
} 
Geografia, território e sociedade na Amazônia

Figura 7 - Porto graneleiro da Cargill no rio Tapajós, em Santarém (2016).

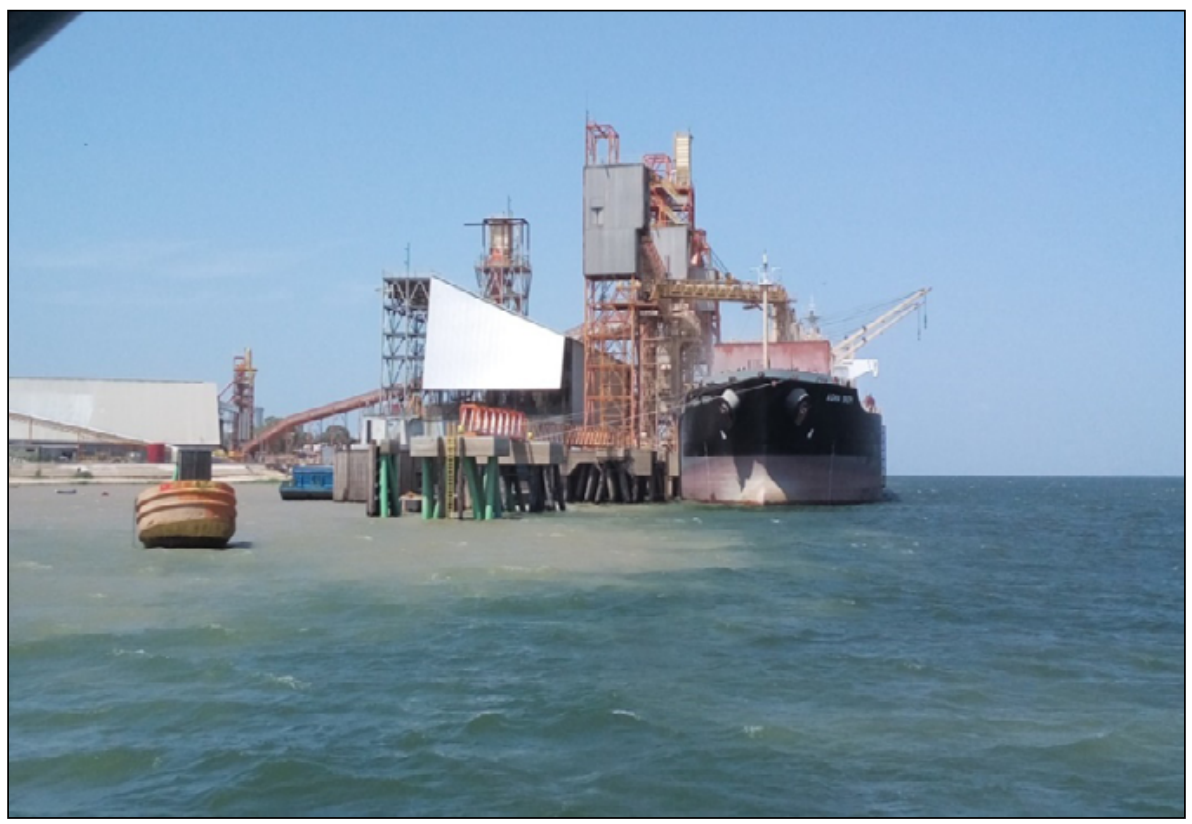

Fonte: Trabalho de Campo, 2016. Foto: Francilene Sales da Conceição.

As forças hegemônicas do agronegócio (Cargill, produtores de soja, empresas de insumos e de transportes, dentre outras) vislumbraram a rodovia Cuiabá-Santarém como novo corredor do agronegócio, conectando o cerrado mato-grossense à floresta amazônica, cuja metamorfose espacial foi transformar áreas de pastagens, áreas florestais e da agricultura camponesa em espaço das commodities, portanto, em um novo espaço de acumulação do capital globalizado.

A abertura concedida aos novos mercados globais nos espaços antes habitados pelo campesinato fez emergir novas relações dialéticas sobre o uso do território. Esse processo contraditório resultou na ampliação do "mercado de terras" e na elevação do preço do hectare, metamorfoseando o valor de uso para o valor de troca das terras (Oliveira, 1991), a fim de atender as pretensões do mercado mundial. Desse modo, no período de 2002 a 2014, a soja invade o oeste do Pará (cidades de Santarém e Belterra), onde a produção cresce de 1.050 toneladas (2002) para 84.996 toneladas (2014), multiplicando por 80 a produção inicial 


\section{Agronegócio e campesinato na Amazônia brasileira}

(Figura 6). Tais dados, certamente, representam um volume insignificante em termos amazônicos, cuja produção foi de 31.661.247 milhões de toneladas em 2014, mas indica os caminhos do agronegócio em áreas com potenciais agrícolas, no qual a Amazônia comparece como nova fronteira agrícola globalizada, dada a "disponibilidade" de terras, sobretudo terras públicas em disputas pelas forças hegemônicas do agronegócio (Silva, 2014a, 2015).

Contudo, os efeitos na geografia agrária são imediatos. Como afirmamos, esses dois municípios estão na região de influência da BR163, que se constitui em área de expansão de grãos (soja, milho e arroz). $\mathrm{O}$ avanço das commodities inflacionou o preço da terra, tornando-se um campo de acumulação da especulação fundiária, processo que remunera o capital agrário e os proprietários de terras, considerando as expectativas de demanda por terras em função do crescimento da produção dos grãos. Conforme os dados da pesquisa Informa Economics FNP (2015), no período de 2010/2014, o preço da terra agrícola e da pastagem em Santarém e Belterra cresceu, respectivamente, $676 \%$ e $434 \%$ (ver adiante Tabela 2). Por isso, convergem os interesses dos grupos empresariais e políticos articulados ao agronegócio em pavimentar a rodovia Cuiabá-Santarém. Os investimentos assentados em redes de transportes e portos permitem a valorização das terras em áreas propícias à produção agrícola, potencializando a competitividade regional a partir da melhoria na fluidez do território (Arroyo, 2001).

A perspectiva de se implantar mais um porto de transbordo de granéis sólidos em Santarém, no lago do Maicá, margem direita do rio Amazonas, tende a ampliar as disputas por terras, a concentração fundiária e a desterritorialização do campesinato, indígenas, quilombolas e ribeirinhos (Conceição, 2017). O projeto previsto para a construção de um dos terminais se encontra em análise e está sob a responsabilidade da Empresa Brasileira de Portos de Santarém Ltda (Embraps). A construção de outros terminais graneleiros na região significa criar logística para facilitar a fluidez territorial e permitir a manutenção de um mercado de terras superaquecido (Lopes, 2016). 
Geografia, território e sociedade na Amazônia

Figura 8 - Plantio de soja no planalto belterrense (2014).

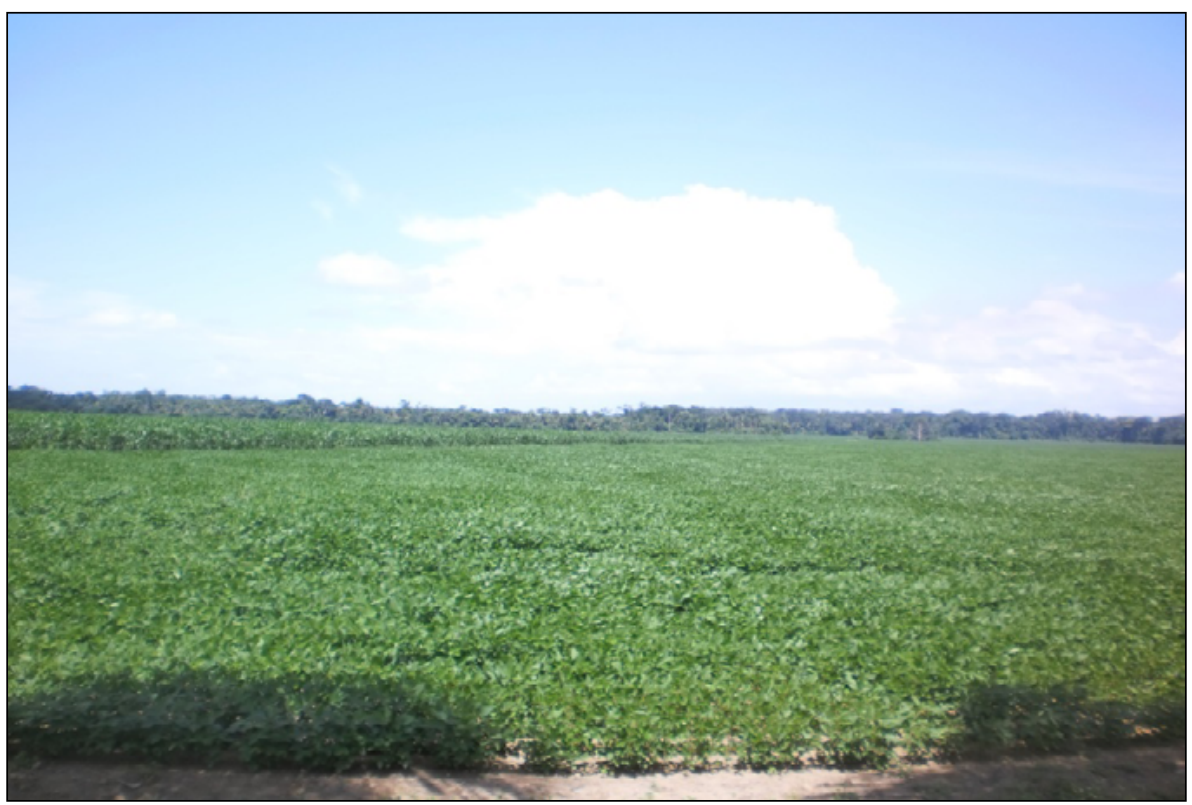

Fonte: Trabalho de Campo, 2014. Foto: Francilene Sales da Conceição.

Os reflexos da elevação dos preços das terras foram evidentes em muitas comunidades do planalto. Antes da chegada dos sojicultores sulistas em Santarém e Belterra, o hectare de terra não ultrapassava R \$ 200,00. Mas recentemente o preço da terra agrícola atingira $\mathrm{R} \$ 7.000,00$ (Conceição, 2017). A “disponibilidade" de terras, o preço acessível de terras e a logística de transportes (rodovia e hidrovia) encontrados no oeste do Pará despontaram como fatores para que migrantes sulistas adquirissem muitas áreas agrícolas e provocassem tantas mudanças no espaço agrário da região. O avanço do agronegócio sojeiro fez com que a sociabilidade monetária do capital permeasse a vida cotidiana das comunidades rurais. Um dos efeitos se manifestou na compra de terras camponesas a preço muito inferior ao do mercado, facilitando a formação de fazendas do agronegócio (Figura 8).

Mas as relações capitalistas também se desenvolvem usando da violência, da agressão simbólica e das representações sociais sobre a natureza e a terra, mobilizando-as como mercadorias. Os camponeses são atingidos pelos conflitos agrários. A terra, na perspectiva do campesinato, 


\section{Agronegócio e campesinato na Amazônia brasileira}

é uma condição fundamental para a recriação da classe social camponesa e que permite a manutenção da vida. O território do campesinato faz uso da policultura, busca sua autonomia no ato de produzir, possui uma diversidade em seus produtos agrícolas e tem a família como a base fundamental do trabalho (Oliveira, 1991). É o que relata um camponês entrevistado na pesquisa de campo, no município de Belterra (1): “Ah, a terra pra mim representa uma mãe [...] é um patrimônio meu, porque é dela que sai toda a nossa alimentação" (Conceição, 2017).

O campesinato não está isento de conflitos. Os camponeses estão constantemente sujeitos às ameaças de mortes, às grilagens de terras e sofrem constantemente pressões do agronegócio. No relato de um camponês entrevistado (2), cristalizam-se esses conflitos: "Aí pros fundo, aí é plantio de soja aí..., aí só que os de lá vêm entrando, de lá pra cá, devagarzinho, né? Aí tem que fincar uns marcos lá, que é pro cabra não poder entrar mais pra dentro, trabalhar no que é deles, né?". Os camponeses querem o direito de desenvolver uma agricultura saudável, autônoma e que possa garantir uma vida justa para suas famílias, sem que necessariamente o outro modelo possa prejudicar o seu trabalho e aquilo que é produzido na terra. Trata-se de um direito ao território, a um outro território que possa expressar sua rica diversidade social.

Os venenos utilizados nas plantações de soja matam as plantações do campesinato. Algumas comunidades do planalto não conseguem nem mais produzir nas suas propriedades porque são prejudicados por esse tipo de atividade. Ainda, quando os camponeses adotam providências junto aos sojicultores, são imediatamente recebidos com ameaças de morte. Diante dos acontecimentos, as lutas socioterritoriais para permanecer na terra estão presentes na realidade dos municípios de Santarém e Belterra. Apesar das resistências, muitos camponeses se encontram temerosos, pensam em vender suas propriedades porque se sentem pressionados e coagidos pelo capital. Esses sujeitos almejam o direito de plantar, produzir e colher, mas, acima de tudo, querem o direito de viver com sua família no território campesino, de forma que esteja livre de pressões e intimidações do capital (Conceição, 2017).

SíNTESE GEOGRÁfica do AGRONEGÓCIO DA SOJA NO SUL DE RONDÔNIA E oeste do PARÁ

A presença da soja no sul de Rondônia e no oeste do Pará permite-nos elaborar alguns apontamentos referentes à nova espacialidade que atinge diretamente os camponeses, as comunidades ribeirinhas, 


\section{Geografia, território e sociedade na Amazônia}

os quilombolas, os pescadores e outros modos de vida que coexistem na região amazônica. Consiste, em absoluto, na formação do espaço do agronegócio globalizado, o que resulta na formação do território do agronegócio em detrimento e em conflito com o território do campesinato e das comunidades rurais amazônicas, o que remete ao entendimento das escalas geográficas nas relações sociais e econômicas nas regiões em análise.

$\mathrm{Na}$ escala nacional e internacional há todo um esforço das agências públicas em ampliar a presença do Brasil no comércio global de commodities agrícolas, buscando sempre conquistar novos mercados. As projeções para o crescimento até a safra 2024/2025 da produção e área de soja no Brasil são, respectivamente, de 126,2 milhões de toneladas e 41,2 milhões de hectares, com aumento de área na ordem de 9,7 milhões de hectares no período de 2014/2015 a 2024/2025 (Brasil, 2015). A perspectiva é que o Brasil possa, a partir do desempenho da soja no período citado, ampliar a produção em 33,9\%, o consumo em $22,9 \%$ e a exportação em 42,21\% (Brasil, 2015, p. 42). Para o mercado mundial, no mesmo período, as exportações de soja $(69$ milhões de toneladas e $45,9 \%$ do comércio externo) e farelo de soja (17,9 milhões de toneladas e $23,6 \%$ do comércio mundial) projetam o fortalecimento do Brasil no comércio exterior, assumindo papel fundamental na geopolítica agrícola mundial.

Ainda que se registre o aumento da produtividade dos fatores da produção do complexo soja (terra, capital, tecnologia e trabalho), a questão da expansão espacial dos grãos pode gerar uma nova geografia regional quando se observa o crescimento agrícola na região do Mapitoba ${ }^{6}$ (Alves, 2015), configurando-se uma nova fronteira agrícola globalizada, deslocando a pressão territorial da Amazônia para essa nova região produtiva. Contudo, embora sejam moderadas as avaliações governamentais para a Amazônia, o crescimento da produção e área agrícola com soja e milho na região indica intenso processo de

\footnotetext{
${ }^{6}$ Região formada pelos municípios localizados no sul do Maranhão, sul do Piauí, leste do Tocantins e oeste da Bahia, onde avança a produção de soja e milho. Trata-se da nova fronteira agrícola globalizada, com presença de produtores migrantes do Sul e do Sudeste do Brasil e empresas multinacionais do agronegócio. Há toda uma perspectiva do Governo para o potencial agrícola dessa região, inclusive com a proposição de uma nova Agência Federal de Desenvolvimento visando a expansão de grãos, tecnologia e logística. Em Alves (2015) há um conjunto de artigos que analisam essa região emergente do agronegócio da soja.
} 


\section{Agronegócio e campesinato na Amazônia brasileira}

territorialização do capital, ocupando áreas que outrora se destinavam à pecuária e à pequena produção agrícola. Essas perspectivas nos remetem a analisar os efeitos territoriais das macropolíticas agrícolas desenvolvidas pelo Governo Federal na região amazônica.

$\mathrm{Na}$ escala regional os espaços em disputas cada vez mais se cristalizam na Amazônia, onde as forças do agronegócio exercem pressão territorial a partir do Mato Grosso. As sub-regiões norte e médio norte mato-grossense formam o espaço do agronegócio sojeiro, caracterizado por uma logística limitada e custos de transportes altíssimos que tendem a fragilizar a competitividade do Mato Grosso no comércio global. Nesse caso, duas frentes de ações se consolidam nesse propósito: a pavimentação da rodovia BR-163 que liga Cuiabá (MT) a Santarém (PA) e a construção da hidrovia Teles Pires-Tapajós. Segundo estimativas, a produção das sub-regiões norte e médio norte, que reúnem 33 municípios, representa $40 \%$ da área plantada com soja, 18,3\% da área com algodão, $50 \%$ da área com milho e 22,5\% do rebanho bovino no estado do Mato Grosso (IBGE, 2015).

Portanto, a necessidade de fluidez territorial (Arroyo, 2001) alude à implantação de mais objetos técnicos que possam aproveitar os recursos territoriais disponíveis a tornar essas sub-regiões mato-grossense mais atrativas ao capital internacional. A pauta territorial das forças hegemônicas do agronegócio impõe a construção de redes técnicas e redes geográficas para convergir o fluxo da mercadoria aos portos de Santarém, no oeste do Pará. Há uma potencialidade do agronegócio nessas regiões, cuja força de crescimento vincula-se inexoravelmente à melhoria da logística e ao custo de transporte, ou seja, a produção do espaço regional articulado aos fluxos da globalização (Silva, 2014b, 2015; Conceição, 2017).

Tabela 1 - Evolução do preço médio da terra na Amazônia, 2010-2014 (R\$/ hectare). Estados selecionados.

\begin{tabular}{|c|c|c|c|c|c|c|c|c|c|}
\hline Estado & \multicolumn{2}{|c|}{ Rondônia } & \multicolumn{2}{|c|}{ Pará } & \multicolumn{2}{|c|}{ Mato Grosso } & \multicolumn{3}{|c|}{ Variação (\%) } \\
\hline \multirow{2}{*}{$\begin{array}{l}\text { Preço } \\
\text { médio } \\
\text { da terra }\end{array}$} & 2010 & 2014 & 2010 & 2014 & 2010 & 2014 & RO & PA & MT \\
\hline & 2.733 & 5677 & 2.635 & 6.236 & 744 & 1.458 & 108 & 137 & 96 \\
\hline
\end{tabular}

Fonte: FNP, 2015. Org.: Autores. 
Tabela 2 - Evolução do preço médio da terra na Amazônia, 2010-2014 (R \$/hectare). Municípios selecionados.

\begin{tabular}{l|c|c|c|c|c|c|c|c}
\hline \multicolumn{1}{c}{$\begin{array}{c}\text { Vilhena } \\
\text { (RO) }\end{array}$} & \multicolumn{3}{c}{ Ariquemes (RO) } & $\begin{array}{c}\text { Santarém/ } \\
\text { Belterra (PA) }\end{array}$ & Vilhena Ariquemes \\
\hline \multicolumn{3}{c}{ Preço médio (R\$/Ha) } & \multicolumn{2}{c}{ Variação (\%) } \\
\hline $\begin{array}{l}\text { Terra } \\
\text { agrícola }\end{array}$ & 7.733 & 13.117 & 2.200 & 6.750 & 967 & 7.500 & 70 & 207 \\
\hline $\begin{array}{l}\text { Área de } \\
\text { pastagem }\end{array}$ & 2.400 & 8.167 & 2.200 & 6.300 & 867 & 4.633 & 240 & 186 \\
\hline
\end{tabular}

Fonte: FNP, 2015. Org.: Autores.

Os efeitos territoriais se fazem presentes nas regiões sul de Rondônia e oeste do Pará, sobretudo, incidindo no preço da terra (Tabelas 1 e 2). Conforme indicamos, nos municípios que centralizam a produção de grãos o preço da terra foi pressionado pela expectativa de construção de redes de transportes, sinalizando aos produtores de soja um verdadeiro comércio territorial com expressiva compra e arrendamento de áreas em regiões promissoras à expansão agrícola, considerando que a redução dos custos de transporte e logística amplia consideravelmente a competitividade regional.

\section{RONDÔNIA: EXPANSÃO AGRÍCOLA E CONFLITOS AGRÁRIOS}

Em Vilhena (sul de Rondônia), o comércio de terras está saturado devido às limitações geográficas em termos de áreas ainda "disponíveis”, geralmente terras públicas ainda não destinadas à produção de grãos. A conversão das pastagens para a agricultura constituiu a dinâmica territorial predominante nessa região. Como resultado, conforme dados da Tabela 2, enquanto a variação da área agrícola foi de $70 \%$, as pastagens cresceram $240 \%$, indicando que a escassez de terras teve como resultado sua elevação na pecuária, sobretudo em áreas não favoráveis aos grãos ou de abertura recente. Esses efeitos econômicos encontraram terreno fértil nas áreas ao longo da rodovia BR-364, sobretudo na região de Ariquemes (novo polo agrícola e frente de desmatamento), cujo resultado, no período de 2010 a 2014, foi o aumento absoluto do mercado de terras, variando $207 \%$ para a terra agrícola e $186 \%$ para áreas de pastagens. Em Rondônia, o preço médio geral da terra agrícola correspondeu 


\section{Agronegócio e campesinato na Amazônia brasileira}

a 108\% (Tabela 1), aumentando nas áreas de recente expansão agrícola e pecuária, exatamente as regiões com maior conflito agrário no estado (CPT, 2016). Ou seja, o preço da terra subiu no sentido da região da soja para as áreas de expansão agropecuária, exploração ilegal de madeira e formação de frentes pioneiras localizadas, no sentido cartográfico do centro-sul para o norte/noroeste de Rondônia (Silva, 2016b).

Tabela 3 - Evolução populacional de Rondônia e região do agronegócio da soja $(2000 / 2010)$.

\begin{tabular}{l|c|c|c|c|c|c|c|c}
\hline $\begin{array}{l}\text { Municípios/ } \\
\text { Estado }\end{array}$ & \multicolumn{5}{c|}{ População (2010) } & \multicolumn{3}{c}{ Variação (2000-2010) } \\
\hline & Total & Urbana & Rural & $\begin{array}{c}\text { Urb. } \\
(\%)\end{array}$ & $\begin{array}{c}\text { Rur. } \\
(\%)\end{array}$ & Total & Urbana & Rural \\
\hline Vilhena & 76187 & 72212 & 3975 & 95 & 5 & 42 & 43 & 33 \\
\hline $\begin{array}{l}\text { Colorado } \\
\text { do Oeste }\end{array}$ & 18602 & 13666 & 4936 & 73 & 27 & -15 & -6 & -33 \\
\hline Cerejeiras & 17030 & 14420 & 2610 & 85 & 15 & -6 & -3 & -22 \\
\hline Corumbiara & 8802 & 2590 & 6212 & 29 & 71 & -16 & 25 & -26 \\
\hline Cabixi & 6309 & 2693 & 3616 & 43 & 57 & -16 & 1 & -25 \\
\hline Chupinguaia & 8304 & 3670 & 4634 & 44 & 56 & 50 & 88 & 30 \\
\hline $\begin{array}{l}\text { Pimenteiras } \\
\text { do Oeste }\end{array}$ & 2322 & 1297 & 1025 & 56 & 44 & -8 & -7 & -9 \\
\hline $\begin{array}{l}\text { Região } \\
\text { Agronegócio }\end{array}$ & 137.556 & 110.548 & 27.008 & 80 & 20 & 15 & 25 & -15 \\
\hline Rondônia & 1.560 .501 & 1.142 .648 & 417.853 & 73 & 27 & 13 & 29 & -16 \\
\hline
\end{tabular}

Fonte: IBGE, 2010. Org.: Autores.

O fenômeno migratório comparece como variável central na formação territorial de Rondônia, principalmente a partir da colonização agrícola iniciada em 1970. Contudo, dado o declínio da migração interestadual na década de 1990, esse processo mudou de escala, restringindo-se à migração intra-estadual no sentido campo-campo e campo-cidade (Tabela 3). A migração intra-estadual e a dinâmica dos preços das terras no espaço agrário rondoniense indicam uma correlação, vinculando ambos os processos à demanda por terra. A população da cidade aumenta sua participação na composição demográfica, com taxa média 


\section{Geografia, território e sociedade na Amazônia}

estadual de $73 \%$, cuja variação intercensitária (2000/2010) foi de 29\%, ao passo que a taxa de população rural restou negativa em $-16 \%$ para o mesmo período.

Na região do agronegócio da soja esses dados são relevantes para compreendermos o impacto do agronegócio na dinâmica populacional. No cômputo geral (Tabela 3), a população cresceu 15\%, taxa levemente superior à média estadual $(13 \%)$, mas centralizada em Vilhena, com crescimento de $42 \%$ na cidade e $33 \%$ no campo. Para os demais municípios dessa sub-região, o impacto negativo se concretizou no espaço agrário com variação negativa de $-15 \%$, sendo que dos 7 (sete) municípios em 5 (cinco) o crescimento negativo variou de $-9 \%$ a $-33 \%$, indicando pressão territorial em terras camponesas e centralidade regional de Vilhena. Contudo, registre-se que em Vilhena a população rural cresceu $33 \%$ em função da criação de assentamentos rurais, muitos deles derivado da luta pela terra.

$\mathrm{Na}$ análise espacial, na região do agronegócio da soja se registra expressivo declínio demográfico nas taxas de crescimento da população rural, o que nos leva a supor que há aumento da concentração de terras nessa região. A migração campo-campo se desloca para as regiões norte/noroeste de Rondônia, registrando crescimento da população rural, cujas evidências empíricas correspondem ao surgimento de vilas e povoados em áreas que até recentemente eram compostas por florestas. No espaço rural de Porto Velho, Nova Mamoré e Buritis o fenômeno das "vilas na floresta" indica o ressurgimento de frentes pioneiras, fenômeno que cresce mesmo após as institucionalizações das políticas de ordenamento do território, a exemplo do Zoneamento Socioeconômico-Ecológico de Rondônia, aprovado em 2000 (Silva, 2016b). Os povoados de União Bandeirantes e Rio Pardo (Porto Velho), Nova Dimensão (Nova Mamoré) e Jacinópolis (Buritis) evidenciam esse processo, cuja população rural migrou da região centro-sul de Rondônia.

$\mathrm{Na}$ escala estadual apontamos duas dimensões espaciais referentes ao acesso à terra configurada pela geografia da soja e da pecuária: no centro-sul de Rondônia a região está consolidada, considerando a perspectiva de Becker (2007); no norte-noroeste e no Vale do Guaporé (fronteira com a Bolívia) esse processo está aberto, registrando áreas recentemente convertidas à agropecuária e, sobretudo, intensa extração ilegal de madeira (crime ambiental). São regiões de ressurgimento de frentes pioneiras e de intensos conflitos agrários e territoriais (Silva, 2016b). 
Oeste paraense: o encontro da Amazônia dos rios com a AMAZÔNIA DAS ESTRADAS

No oeste paraense, como afirmamos, nos municípios de Santarém e Belterra, na geografia da soja há o encontro da Amazônia dos rios com a Amazônia das estradas (Valbuena, 2008). São espacialidades diferentes, onde se localiza o limite do avanço espacial das commodities agrícolas na Amazônia. Diferente de Rondônia, em que a soja avança em áreas de colonização recente vinculada à agropecuária, no oeste paraense se caracteriza por ser a Amazônia dos rios, das florestas e dos povos e comunidades tradicionais extrativistas (Conceição, 2017).

O encontro conflituoso do capital globalizado se realiza nos caminhos fluviais dos ribeirinhos, modificando o sentido do lugar, dos rios e da natureza. Nessas áreas a solidariedade orgânica é contrastada com a solidariedade organizacional do capital (Santos, 1996; Santos; Silveira, 2005; Silva, 2015), expressas nas escalas geográficas do cotidiano multitemporal e multiespacial, em que o local e o global compõem o mosaico espaço-tempo do lugar (Figura 9). Para as comunidades ribeirinhas o rio é vida social. Para o capital é tão somente um sistema de objeto que serve ao fluxo internacional da mercadoria. $\mathrm{Na}$ paisagem regional os conteúdos sociais e geográficos conformam o acúmulo desigual do tempo, indicando as rugosidades do espaço e sua hibridez sociotécnica (Santos, 1996). 
Figura 9 - Rio Tapajós: barcos e canoas dos ribeirinhos e o porto da Cargill em Santarém (2014).

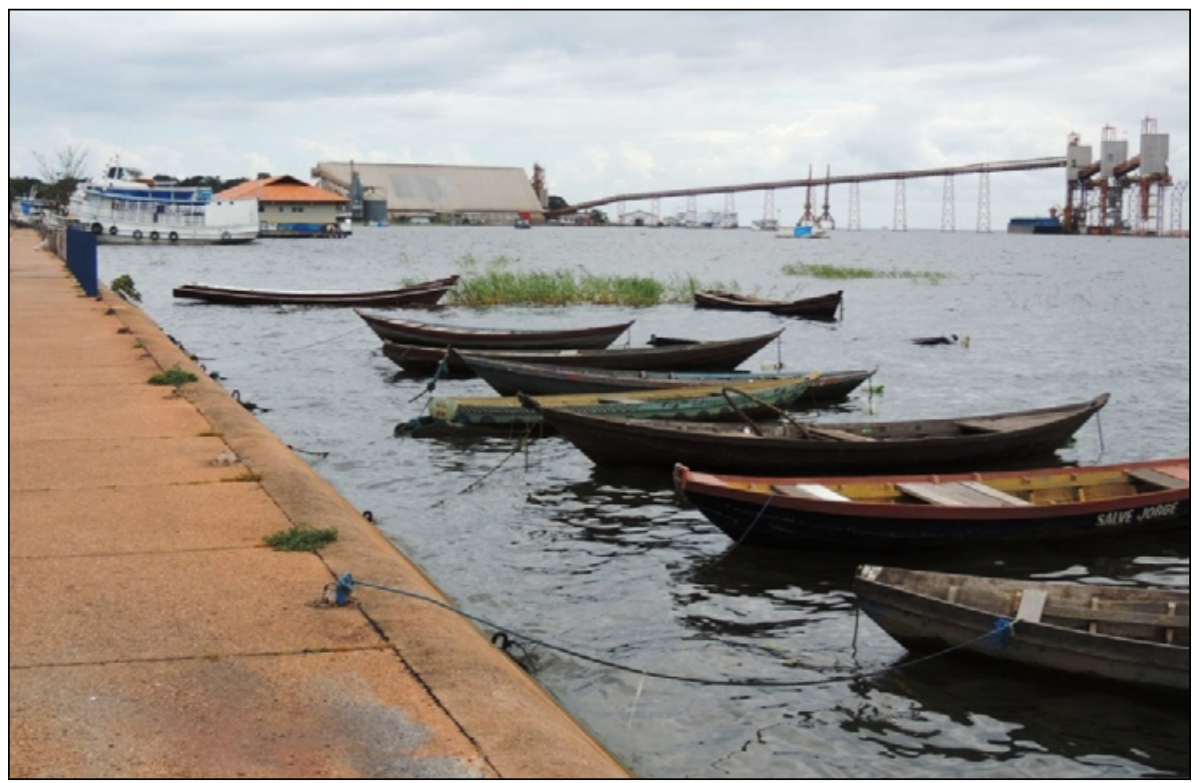

Fonte: Trabalho de Campo, 2014. Foto: Ricardo Gilson da Costa Silva.

Na região do Baixo Amazonas (oeste paraense), o modo de vida das comunidades rurais, ribeirinhas e urbanas se distingue pela presença dos rios nos fluxos econômicos, sociais e culturais que qualificam o espaço local e dão unidade à tríade campo-cidade-floresta como condição de entendimento do espaço total, instituindo uma geografia da diferença. Em específico, nas comunidades rurais de Santarém e Belterra, o modo de vida camponês-ribeirinho-extrativista muito se diferencia das sub-regiões amazônicas em que está assentada a economia da pecuária e dos grãos de soja vinculadas aos circuitos espaciais da produção (Santos, 1988), como ocorre no Mato Grosso e em Rondônia. Na geografia desses dois municípios o agronegócio da soja entra em cena, impondo sua racionalidade, produzindo estranhamentos nos lugares. 
Figura 10 - Cartografia do Arco Norte, a nova rota do agronegócio (2014).

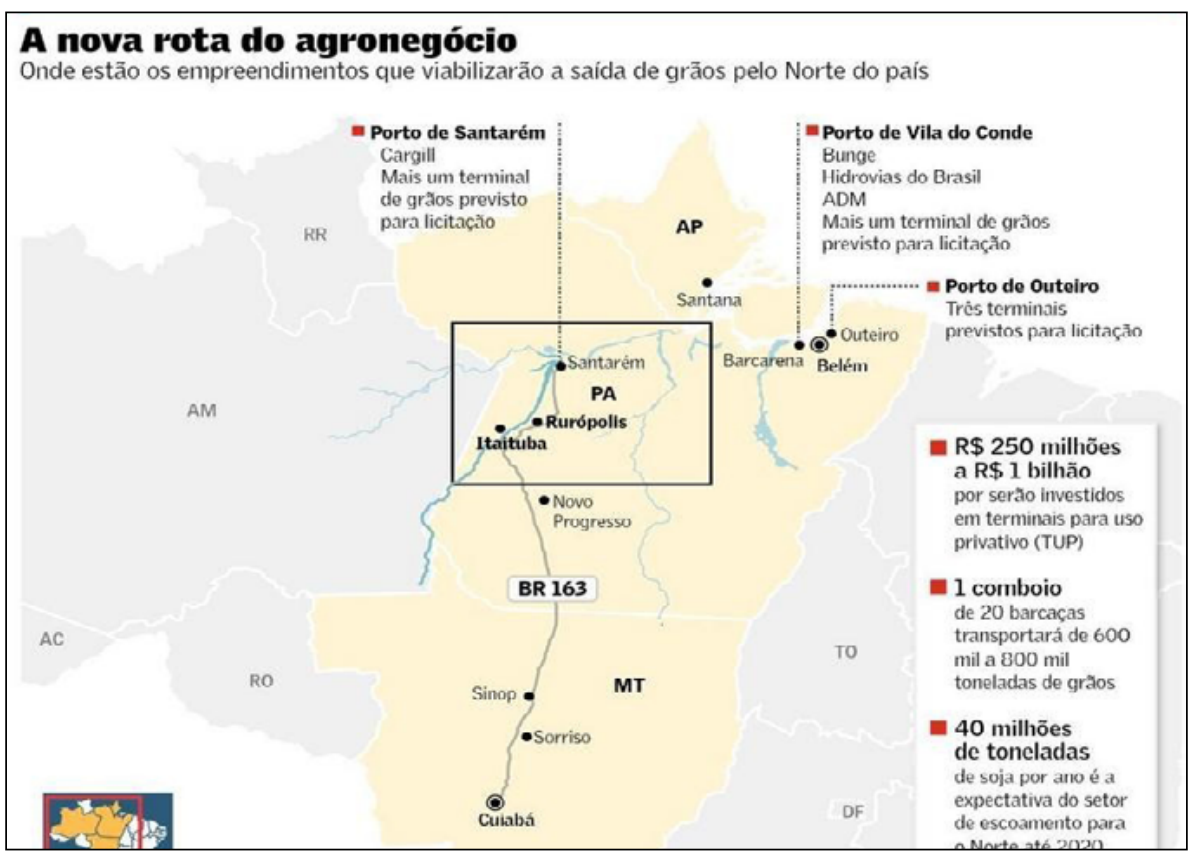

Fonte: Barros, 2014.

A principal pressão territorial, como argumentamos, desloca-se do Mato Grosso por meio do eixo rodoviário da BR-163. Os projetos territoriais são distintos e contraditórios, exigindo a mobilização política dos movimentos sociais à resistência e produção de contrarracionalidades ao processo de expropriação e coerção territorial imposto pelo capital globalizado (Cargill, Bunge, Amaggi, dentre outros), agentes do agronegócio (médios e grandes produtores de soja, empresas de insumos, empresas de assistência tecnológica, empresas de transportes) e poder público (governos Municipal, Estadual e Federal).

No oeste paraense, quantidades significativas de terras destinadas ao uso camponês, onde desenvolviam uma agricultura que servia tanto à subsistência familiar quanto fornecia alimentos ao mercado local, foram convertidas em espaços da produção de commodities, causando diretamente desflorestamentos de grande magnitude e expropriação do campesinato de seus respectivos territórios. A territorialização dos agentes hegemônicos no espaço do campesinato modificou as relações 


\section{Geografia, território e sociedade na Amazônia}

de trabalho e a forma de se relacionarem e fazerem uso da natureza (Conceição, 2017). Todo esse processo tende a ampliar a escala geográfica das dinâmicas territoriais se confirmadas as obras de infraestrutura rodoviária, hidroviária, hidroportuária e ferroviária, que transformarão o oeste paraense em novo eixo de fluidez territorial do Brasil (Arroyo, 2001), escoando a produção agropecuária do Norte e Médio Norte do Mato Grosso (Figura 10). Com a demanda da China por grãos e minérios, a saída pelo corredor de transporte denominado Arco Norte tende a acelerar, considerando a redução do custo de transporte em até $34 \%$, o que potencializa a produção de grãos na Amazônia, especialmente na região oeste do Pará (Barros, 2014). Estima-se, segundo os estudos do Rabobank, banco de origem holandesa, que as exportações de soja pelos portos de Manaus (Amazonas), Santarém e Barcarena (Pará) e Itaqui (Maranhão) podem crescer até 130\% em 10 anos, considerando os investimentos anunciados pelas empresas ADM, Amaggi, Bunge, Cargill, Fiagril, Hidrovias do Brasil e Louis Dreyfus (Lopes, 2016).

As cartografias geopolíticas estão postas pelo capital hegemônico. Anuncia-se para o oeste paraense todo um conjunto de transformações espaciais ligadas aos vetores externos da globalização. A Amazônia dos rios e da floresta, dos espaços ribeirinhos e camponeses, tendem a sofrer compressões espaço-temporais aceleradas pela geopolítica mundial da soja, povoando a paisagem rural com objetos técnicos. Por conseguinte, com a pavimentação, ainda inconclusa, da rodovia BR-163 sob a iniciativa do Governo Federal e a ampliação portuária nas margens do rio Tapajós, novos processos de mercantilização das terras camponesas são estimulados e pressionados por médios e grandes proprietários, empresas do Agronegócio Nacional e pelo capital global (Torres, 2005). Em muitas áreas de Belterra e Santarém, as chácaras, os sítios e/ou colônias de camponeses - como são titulados pelos sujeitos sociais - foram convertidos em espaços da produção de grãos a partir da compra ou de arrendamentos de terras feitos por grandes fazendeiros.

O que outrora existia no eixo da rodovia Santarém-Cuiabá, que engloba o município de Belterra, perfaziam grandes áreas de floresta conservada e/ou preservada, utilizadas pelo campesinato para o extrativismo animal e vegetal, e no desenvolvimento de uma agricultura artesanal, familiar e de subsistência. Sem camponeses na terra, dado a expropriação e a migração para outras áreas da região, o fato se configura como um processo de "trituração" da floresta com o uso de máquinas pesadas e a preparação do solo para o cultivo de grãos. Esse espaço expressa as 


\section{Agronegócio e campesinato na Amazônia brasileira}

múltiplas contradições geradoras das conflitualidades entre camponeses e sojicultores, no encontro conflituoso da Amazônia dos rios e Amazônia das estradas.

\section{CONSIDERAÇÕES FINAIS}

A expansão da soja na Amazônia atinge espaços territorializados pelo campesinato, que passa a sofrer pressões do capital globalizado. Se nas décadas de 1960/1990 o capital se realizava através da mineração e da energia elétrica, no campo as grandes fazendas de gado e empresas madeireiras compunham a paisagem agrária. $\mathrm{O}$ camponês se relacionava com esses sujeitos do capital, ora em conflito agrário, ora com a produção agrícola complementar comercializada nas cidades na escala local e regional.

Contemporaneamente, a reestruturação produtiva da agricultura atinge a Amazônia a partir do Mato Grosso, expandindo-se para áreas de Rondônia e do Pará e, sobremaneira, impactando a espacialidade camponesa. As verticalidades (Santos, 1996) do agronegócio fazem parte do cenário agrário/agrícola e regional do oeste do Pará e do sul de Rondônia, no qual esses espaços dão sentido ao funcionamento global da economia, instaurando novas lógicas da globalização (Silva, 2015).

Em verdade, há a formação de manchas do meio técnico-científico-informacional (Santos, 1996; Silva, 2014 e 2015), onde os agentes hegemônicos vão suprimindo e dominando as comunidades camponesas, produzindo as contradições e acentuando as migrações campo-cidade ou campo-campo. Entretanto, o campesinato, enquanto modo de vida e classe social, se (re)produz no interior do modo de produção capitalista e cria estratégias de resistência ao modelo excludente e antagônico (Oliveira, 1991), em que o aumento dos conflitos no campo por terra, subsolo, água e floresta são os tristes indicadores desses acirramentos socioterritoriais.

As geografias que analisamos nos municípios da Amazônia indicam que as transformações forçadas pelos fluxos da agricultura globalizada não se realizam somente em áreas de densidade técnica e produtiva, mas em regiões periféricas que acabam sendo reserva de lugares do capital global (Silva, 2014a e 2015). O território e seus diversos modos de existência, dialeticamente, reúnem e separam os processos sociais que lhes dão vida. Essas disputas territoriais contemporâneas na Amazônia cristalizam a produção do espaço agrário e regional vinculado às variáveis globais. Sua leitura passa, numa abordagem teórico-metodológica, pelo entendimento do espaço como produção social, como totalidade concreta. 


\section{REFERÊNCIAS}

ALVES, V. E. L. (org.). Modernização e regionalização nos cerrados do Centro-Norte do Brasil. Rio de Janeiro: Consequência Editora, 2015.

ARROYO, M. M. Território nacional e mercado externo: uma leitura do Brasil na virada do século XX. Tese de doutorado. Departamento de Geografia, FFLCH/USP, São Paulo, 2001.

BARROS, B. Tapajós inverte fluxo de exportação de grãos. Jornal Valor, São Paulo, p. 14, 25 fev. 2014.

BECKER, B. Amazônia: geopolítica na virada do III milênio. 2. ed. Rio de Janeiro: Garamond, 2007.

BERNARDES, J. A. O novo tempo do capital no cerrado: a criação de novos territórios produtivos. In: BERNARDES, J. A., ARACRI, L. A. (orgs.). Espaço e circuitos produtivos: a cadeia carne/grãos no cerrado mato-grossense. Rio de Janeiro: Arquimedes, 2010.

BRASIL. Ministério da Agricultura, Pecuária e Abastecimento (MAPA). Projeções do Agronegócio - Brasil 2014/2015 a 2024/2025 - Projeções de Longo Prazo. Brasília, julho de 2015.

CONCEIÇÃO, F. S. (2017) A territorialização do capital e a expansão do agronegócio sojeiro: lutas e (re)existências dos camponeses/camponesas das comunidades Nova Esperança e Nova Aliança no município de Belterra-Pará. Dissertação de Mestrado em Geografia da Universidade Federal de Rondônia (UNIR). Porto Velho, 2017.

CPT-RO (Comissão Pastoral da Terra em Rondônia). Vilhena, cidade de conflitos agrários. 8 de novembro de 2013. Disponível em: http://cptrondonia.blogspot.com.br/2013/03/vilhena-cidade-de-conflito s-agrarios. html. Acesso em: 12 ago. 2014.

CPT-NACIONAL. Conflitos no campo Brasil 2016. Goiânia, 2016.

ELIAS, D. Relações campo-cidade, reestruturação urbana e regional no Brasil. XII Coloquio de Geocrítica, Universidad Nacional de Colombia, Bogotá, 7 a 11 de maio de 2012.

FNP. Preços das terras têm forte alta nos Estados do Norte. Informa Economics FNP - Valor Econômico, 24/4/2015. Disponível em: www. informaecon-fnp.com/noticia/11519. Acesso em: 30 abr. 2015.

IBGE. Censo agropecuário - 2006: Brasil, grandes regiões e unidades da federação. Rio de Janeiro, 2006. 
IBGE. Instituto Brasileiro de Geografia e Estatística. Produção agrícola municipal. Rio de Janeiro, 2015.

IBGE. Instituto Brasileiro de Geografia e Estatística. Censo Demográfico - 2010: Brasil, grandes regiões e unidades da Federação. Rio de Janeiro, 2010.

LOPES, F. Exportação de soja pelo Norte deve crescer $130 \%$ em 10 anos. Jornal Valor, São Paulo, 25 jun. 2016. Disponível em: www2.valor.com.br/agro/4611197/exportacao-de-soja-pelo-norte-deve-crescer-130-em-10-anos. Acesso em: 15 out. 2016.

MCMICHEL, P. Regimes alimentares e questões agrárias. São Paulo/ Porto Alegre: Editora Unesp/Editora da UFRGS, 2016.

OLIVEIRA, A. A agricultura camponesa no Brasil. São Paulo: Ed. Contexto, 1991.

PORTO-GONÇALVES, C. W. Amazônia, Amazônias. São Paulo: Contexto, 2001.

RIBEIRO, A. F. A.; SILVA, R. G. C.; CORREA, S. S. Geografia da soja em Rondônia: monopolização do território, regionalização e conflitos territoriais. Campo - Território, v. 10, 2015, p. 180-201. Disponível em: www.seer.ufu.br/index.php/campoterritorio/article/viewFile/28439/17010. Acesso em: 17 dez. 2015.

SANTOS, M. Metamorfoses do espaço habitado: fundamentos teóricos metodológicos da Geografia. São Paulo: Hucitec, 1988.

SANTOS, M. A natureza do espaço: técnica e tempo, razão e emoção. São Paulo: Hucitec, 1996.

SANTOS, M. Da totalidade ao lugar. São Paulo: Edusp, 2005.

SANTOS, M; SILVEIRA, M. L. O Brasil: território e sociedade no início do século XXI. 8. ed. Rio de Janeiro/São Paulo: Record, 2005.

SCHLESINGER, S.; NORONHA, S. O Brasil está nu! O avanço da monocultura da soja, o grão que cresceu demais. Rio de Janeiro: FASE, 2006.

SILVA, R. G. C. Globalização e dinâmicas territoriais em Rondônia Região Amazônica. Geograficando - Revista de Estudios Geográficos, v. 5, 2009, p. 41-61.

GILSON, R. Das margens do Madeira ao interior da floresta: percursos da formação socioespacial de Rondônia (1970-1995). In: Colonização, território e meio ambiente em Rondônia: reflexões geográficas. Curitiba: Editora SK, 2012. 
GILSON, R. A regionalização do agronegócio da soja em Rondônia. GEOUSP - Espaço e Tempo, São Paulo, v. 18, n. 2, 2014a, p. 298-312.

GILSON, R. Globalização e fragmentação do espaço agrário em Rondônia. RDE - Revista de Desenvolvimento Econômico, v. XVI, p., 2014b, 163-174.

GILSON, R. Amazônia globalizada: da fronteira agrícola ao território do agronegócio - o exemplo de Rondônia. Confins - Revue franco-brésilienne de géographie [En ligne], 23, posto on-line no dia 1 março 2015. Disponível em: http://confins.revues.org/9949. Acesso em: 2 mar. 2015.

GILSON, R. Agronegócio e campesinato em Rondônia. In: Geografia Agrária no Brasil: disputas, conflitos e alternativas territoriais. Jundiaí: Paco Editorial, 2016a.

GILSON, R. Agentes, procesos y conflictos en la gestión territorial en el estado de Rondônia (Brasil). Polis, Santiago, v. 15, n. 45, p. 319344, dic. 2016b. Disponível em: http://dx.doi.org/10.4067/S071865682016000300016. Acesso em: 10 mar. 2017.

THÉRY, H. Rondônia - Mutations d'un Territoire fédéral en Amazonie Brésilienne. Paris, Université Paris I. (Tese de Doutorado), 1976.

THÉRY, H. Rondônia mutações de um território federal na Amazônia brasileira. Curitiba: SK Editora, 2012.

TORRES, M. (org.). Amazônia revelada. Brasília: Cnpq, 2005.

TRINDADE JR., S. C. C.; SILVA, M. A. P.; AMARAL, M. D. B. Das "janelas" às "portas" para os rios: compreendendo as cidades ribeirinhas na Amazônia. In: Cidades ribeirinhas na Amazônia: mudanças e permanências. Belém: Edufpa, 2008.

VALBUENA, R. Santarém, entre la Amazonia de los ríos y la Amazonia de las carreteras. Confins - Revue franco-brésilienne de géographie [En ligne], 3 | 2008, posto on-line no dia 24 abril 2008, consultado em $1^{\circ}$ abril 2016. Disponível em: http://confins.revues.org/3903.

VALVERDE, O. (coord.) A organização do espaço na faixa da Transamazônica: introdução sudoeste amazônico e regiões vizinhas. Rio de Janeiro: IBGE/Incra. v., 1979. 


\title{
CARTOGRAFIA DAS HIDROESTRATÉGIAS
}

NA AMAZÔNIA BRASILEIRA ${ }^{7}$

\author{
Luís Augusto Pereira Lima" \\ Ricardo Gilson da Costa Silva"*
}

\section{INTRODUÇãO}

As narrativas amazônicas referentes a uma perspectiva territorial normalmente perpassam por uma gama diversa de ações governamentais e empresariais, fazendo contrapontos, de maneira intermitente, às ações dos povos e comunidades tradicionais amazônicas, mas que nessa última década tende a ser contínuas. Dentre as ações, pode-se considerar as construções de rodovias, ampliação do desmatamento, crescimento da pecuária, extração madeireira, extração mineral, hidrovias, agronegócio e, com proeminência, a construção de hidroelétricas que visam reestruturar o espaço amazônico aos fluxos econômicos nacional e internacional.

Neste artigo, realizamos uma breve reflexão sob o que estamos qualificando como hidroestratégias, ou seja, processos relacionados aos ajustes na gestão do território e na relação território e norma, como condição para a expansão do capital hidroenergético na Amazônia. Referenciamos a análise a partir do Macrozoneamento Ecológico-Econômico da Amazônia (MacroZEE), que projeta à região como potencialidade hídrico-energética. Por esta "potencialidade" compreende-se o quantitativo de rios amazônicos como recursos hídricos que já estão identificados para construção de hidroelétricas, mesmo com restrições ambien-

\footnotetext{
${ }^{7}$ Artigo publicado em: LIMA, L. A. P; COSTA SILVA, R. G. Cartografia das hidroestratégias na Amazônia brasileira. ACTA Geográfica, Boa Vista, v. 12, n. 28, jan./abr. de 2018. p. 129-142.

https://orcid.org/0000-0003-0390-4315

"* https://orcid.org/0000-0002-3348-9629
} 


\section{Geografia, território e sociedade na Amazônia}

tais em vista. Por conseguinte, abordaremos as perspectivas inerentes ao que nos referimos como uma potencialidade para as hidroelétricas em dois mapas síntese, ancorados como cartografias das hidroestratégias na Amazônia.

Em vista das possibilidades de execução dessas obras, as hidroelétricas projetam uma intervenção no território sem precedentes, considerando a escala geográfica dos impactos territoriais. Para tanto, apresentamos os mapas como referência espacial dessa narrativa, sobretudo, indicando nossa metodologia, cuja abordagem refere-se a uma pesquisa qualitativa com espacialização cartográfica das localizações com potencial das hidroelétricas, revisão bibliográfica e trabalho de campo.

Nesse cenário complexo, há toda uma luta política para a recodificação dos códigos jurídicos que violam os territórios dos povos e comunidades tradicionais amazônicas, instrumentos que visam flexibilizar as relações sociais, econômicas e mesmo a autonomia desses grupos sociais. Por sua vez, podem garantir a construção das hidroelétricas sem ou com apenas as mínimas medidas de prevenção ambiental e social. Tais instrumentos, como afirmamos, tendem a flexibilizar os territórios e podem constituir uma frente possível de mercantilização e apropriação dos recursos hídricos. Para isso, a discussão da relação território e normas nos parece ser um caminho adequado para verificarmos as transformações em cursos e potencialidades vindouras.

As narrativas referentes a construção de hidroelétricas na região Amazônica vigoram desde a década de 1980, que, após um hiato temporal, emerge com mais intensidade no planejamento governamental no início desse século, ampliando a escala geográfica e a intensidade territorial na região (Figura 1). Notadamente compõe um conjunto de representações que indicam uma cartografia dos grandes sistemas de objetos, como uma cartografia das multiterritorialidades em disputas. 


\section{Cartografia das hidroestratégias na Amazônia brasileira}

Figura 1 - Hidroelétricas em operação, em obras e planejadas na Amazônia (2014).

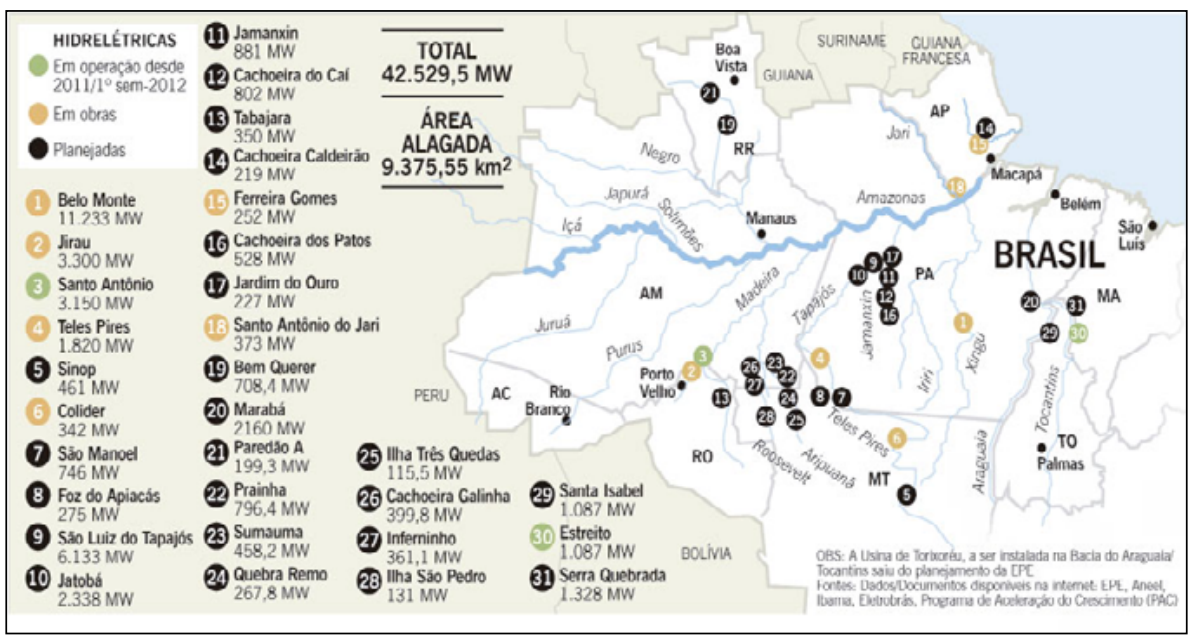

Fonte: Ecodebate, mapa por Cândido Cunha, em Língua Ferina, 2014.

Para agregar a esta discussão, os mapas que apresentamos nos permitem dois pontos de vista sobre o contexto das hidroelétricas, que iremos abordar na intersecção desta cartografia das hidroestratégias. Um em que as hidroelétricas seguem o ritmo das construções determinado pelo que se interpreta do MacroZEE e outro em que a Amazônia, como a conhecemos, será reduzida a uma porção chamada de "Coração Florestal". Sob tal expectativa a Figura 1 expressa, de forma inicial, os avanços das hidroelétricas na região, implicando na consolidação e/ou implantação de um conjunto de hidroelétricas, além de outros projetos de exploração econômica, que tendem a dinamizar a Amazônia brasileira como um cenário de fonte de recursos, de acumulação do capital em função da exploração intensiva da natureza.

\section{SOBRE AS HIDROESTRATÉGIAS, TERRITÓRIO E NORMAS}

A Amazônia brasileira constitui uma sociodiversidade que envolve em seu tecido espacial uma série de grupos sociais que qualificam a região em sua relação material e imaterial, conformada numa perspectiva geográfica na relação homem e natureza, comunidade e território, sociedade e espaço. 
No espaço agrário, florestal e fluvial amazônico convivem comunidades de pescadores, indígenas, quilombolas, seringueiros, extrativistas e camponeses; assim como dezenas de cidades ribeirinhas que vivenciam territorialidades em disputas, sobretudo com o que se pode denominar de grandes projetos, a exemplo, dentre outros, das usinas hidroelétricas de Belo Monte (no Estado do Pará), Jirau e Santo Antônio (no Estado de Rondônia). Nessa perspectiva, questiona-se essas modalidades de intervenção propostas pelo Estado quanto à repartição dos recursos do território, reconhecendo que as ações das grandes empresas (capital), que qualificamos de agentes hegemônicos (Santos, 1996), incidem no ambiente social dos povos e comunidades tradicionais amazônicas, assim como em suas práticas, saberes e territórios.

Como noção orientadora, numa primeira reflexão, denominamos de hidroestratégias as ações do Estado articuladas com o capital (nacional e internacional) que projetam à Amazônia um espaço de acumulação no âmbito da intensa mercantilização dos recursos hídricos, notadamente para produção de energia, a partir de grandes hidroelétricas (objetos técnicos). Disso resulta a produção não somente da mercadoria de energia em si, mas a necessária configuração do espaço regional em domínios territoriais, visto ser imperativo à produção de energia elétrica (mercadoria) a apropriação e dominação de áreas pelos agentes hegemônicos e pelo Estado (Figura 2). 


\section{Cartografia das hidroestratégias na Amazônia brasileira}

Figura 2 - Espaço dividido no rio Madeira, em Porto Velho (2012). No primeiro plano o espaço do sagrado, no segundo plano, o domínio da hidroelétrica de Santo Antônio.

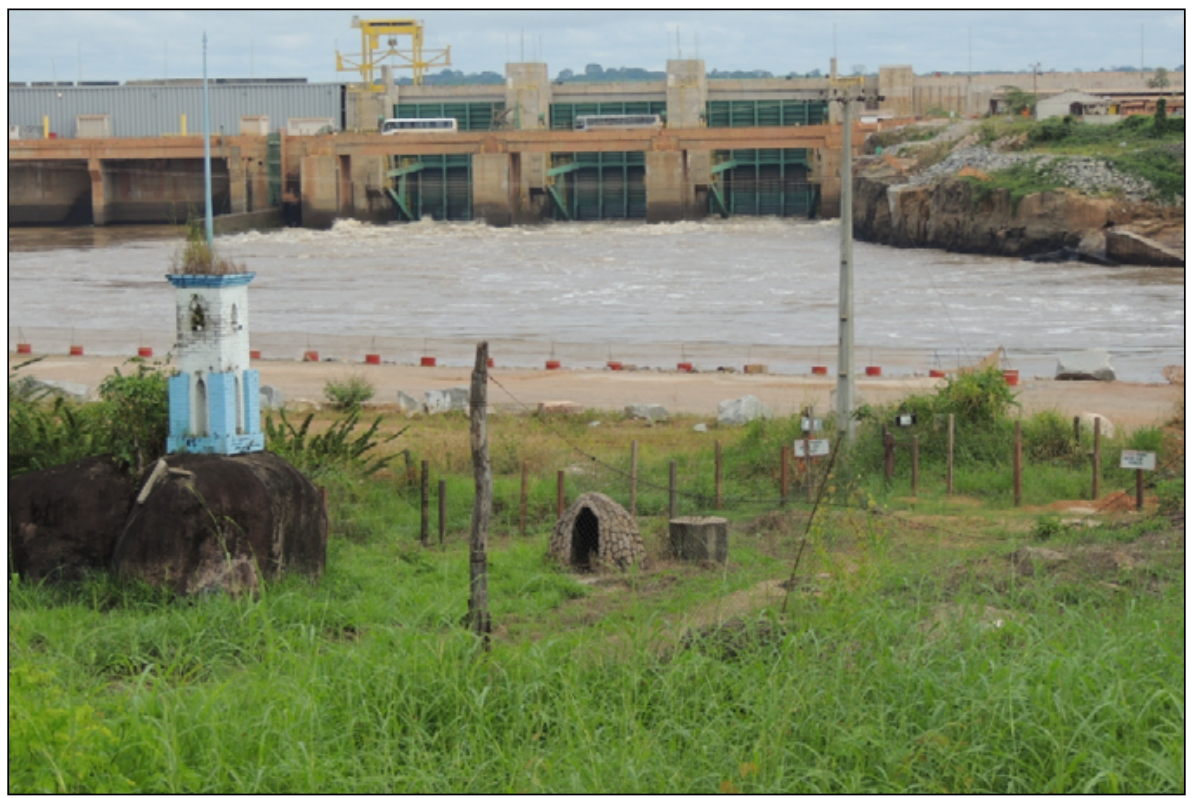

Fonte: Autores.

Significa articular a produção energética com a formação de territórios, na medida em que imperativamente se faz necessário o controle de áreas, portanto seu domínio, garantindo a territorialidade do capital industrial-hidroenergético. Qualificam-se dois processos de produção do espaço quando os pares energia e território imprimem ordens diferentes e antagônicas no seio social (Becker, 2006).

A partir das hidroestratégias o capital projeta na relação social, ao menos, duas narrativas de "desenvolvimento econômico e social". A primeira narrativa versa sobre o crescimento econômico a partir das métricas do emprego formal e das firmas que compõem a economia local e regional. A expansão do mercado de trabalho e a geração de divisas incidem positivamente no PIB estadual, tornando-se elementos da propaganda governamental, das elites locais e dos agentes hegemônicos; vivenciando a psicosfera da modernidade e das hidroelétricas (Santos, 1996; Silva, 2015). 


\section{Geografia, território e sociedade na Amazônia}

A segunda narrativa projeta às comunidades e populações atingidas pela barragem um universo de benefícios socioeconômicos, no qual esses grupos podem, especula-se, em curto prazo, superar as intempéries sociais e ambientais dos deslocamentos. Concretiza-se, para as comunidades atingidas pelas barragens, um espaço social de trabalho e produção, formalizados nos reassentamentos rurais e nas inúmeras promessas de crescimento econômico e de progresso social desses grupos, algumas vezes tentando os transformar em "empreendedores rurais", seja com a produção agrícola (farinha e frutas, por exemplo), pescado ou "turismo", vinculando-os a um mercado "generoso" para o consumo de suas mercadorias. $\mathrm{O}$ discurso acadêmico conservador positivista vai qualificar, com o conceito de resiliência, essa capacidade de "adaptação" dos atingidos pelas hidroelétricas, negando o violento processo de desterritorialização das comunidades e territorialização do capital, o que significa para os agentes hegemônicos a privatização da natureza e a apropriação dos rios e dos recursos hídricos.

Contudo, normalmente nesses espaços de apropriação/dominação, objeto da ação do capital e do Estado, responsáveis pela construção e gestão das hidroelétricas, ou seja, nos rios amazônicos, encontra-se uma sociabilidade histórica ancorada nos inúmeros grupos sociais que alicerçam suas vidas, suas existências, na conjugação da natureza com o trabalho humano. A cartografia localiza e revela a espacialidade humana manifesta na relação comunidade e território, mapeadas nas formas de trabalho e organização social. Nessa relação existencial e histórica, no par conceitual comunidade e território, estão os povos indígenas, as comunidades quilombolas e ribeirinhas, os pescadores artesanais, o campesinato extrativista, os seringueiros e os agricultores familiares, assim como diversos grupos sociais que articulam sua vivência no espaço-tempo florestal, fluvial e agrário.

Nessa perspectiva, a cartografia das hidroestratégias tende a suprimir do mapa essas comunidades, pois a desterritorialização é a resultante imediata - na ótica do capital e do Estado - e expressa uma drástica mudança social desses grupos (Saquet, 2007). Não se trata somente, numa perspectiva tecnocrática, de reassentamento dos atingidos ou deslocamento compulsório de ribeirinhos, mas de uma mudança social e territorial desses grupos sociais. Muito menos de resiliência (conceito e narrativa atenuante), mas de desterritorialização das comunidades em favor do capital, do controle da natureza e do território pelos agentes hegemônicos, sob o beneplácito do Estado. Portanto, a instituição de um 


\section{Cartografia das hidroestratégias na Amazônia brasileira}

outro domínio vertical, de uma hierarquia rígida, na medida em que não há elasticidade para a presença e convivência dos atingidos.

Todavia, para a eficácia da ação do Estado e dos agentes hegemônicos e do capital industrial-hidroenergético, opera-se transformações no uso do território com a institucionalização de normas jurídicas, na perspectiva de recodificação do ordenamento e gestão do território. A ação hegemônica exige, no plano do Estado, uma configuração territorial regida por normas jurídicas (gestão do território) garantidora da ação do capital na territorialização de seus projetos. O argumento da "segurança jurídica", expressamente reclamado na imprensa brasileira pelos porta-vozes dos setores neoextrativistas - formados pelo capital mineral, elétrico, petrolífero, madeireiro, agropecuário e agronegócio - requer do Estado, como principal gestor do território, garantias de que seus projetos territoriais e a acumulação do capital não sejam interpelados pelas ações políticas e jurídicas dos sujeitos e das comunidades afetadas pelo processo de desterritorialização promovido pelas grandes obras.

Instaura-se uma relação política do uso do território (formas-conteúdo, ações e objetos) e situação jurídica (normas), ambas socialmente construídas. Para pensar a conformação dos lugares afetados por grandes projetos, incorporamos à análise os conceitos de território normado e território como norma (Santos, 1996; Antas Junior, 2005). O primeiro refere-se ao território ordenado pelo Estado em sua configuração espacial, a partir de regimentos e normas que substantivam sua ação e soberania. Do ponto de vista do Estado, trata-se do território de todos os entes que são objetos privilegiados da ação do Estado (território como objeto), o que também qualifica a soberania do Estado-Nação.

Quanto ao território como norma, refere-se aos processos de modificação normativa, por parte do capital ou dos grupos sociais, referente ao uso e presença social nesses espaços, o que gera agudos conflitos territoriais (território como sujeito). Abrangem a perspectiva da vivência territorial a partir do lugar (cotidiano, proximidade, coexistência, simbologia) alimentado pela solidariedade orgânica construída pelos grupos sociais na relação com a natureza, produto da apropriação simbólica e econômica desses grupos. Para as comunidades o território é sujeito mobilizador e existencial. Para o capital, o território é recurso, o que exigem novas normas jurídicas para seu controle e reprodução, impondo às comunidades normas e códigos estranhos ao convívio socioterritorial, portanto, instauradora de nova regulação do território, do espaço apropriado/dominado. Para as comunidades atingidas pelas barragens o 


\section{Geografia, território e sociedade na Amazônia}

território como norma é morada, abrigo, porque reúne trabalho, natureza, tempo-espaço, uma amálgama existencial (Gottmann, 1972; Santos, 1996, Antas Júnior, 2005). Para o capital, ao território se impõem novas regulações: as normas dos agentes hegemônicos para com o uso da natureza (solidariedade organizacional); às comunidades, o território expressa (re)existências, luta social, territorialidades em movimento histórico (Porto-Gonçalves, 2006; Santos, 1996).

Esse cenário na Amazônia, espaço dos grandes projetos hidroelétricos, minerais e agropecuários, implica em uma agenda territorial de revisão de todos os códigos normativos ${ }^{8}$ referentes ao território (sujeito) e os domínios territoriais (formas geográficas). Esse processo de reformulação do uso e significado desses domínios territoriais, concretizado em unidades de conservação, terras indígenas, áreas quilombolas, espaços comunitários florestais, fluviais e agrários, do solo e do subsolo entram na agenda de recodificação, relacionando a dialética território normado e território como norma. A recodificação territorial da Amazônia no âmbito do MacroZEE ${ }^{9}$, neste caso, sinaliza o deslocamento espacial de grandes sistemas de objetos para a região, projetando o que é visto como uma potencialidade para as hidroelétricas.

\section{Cartografias das POTENCIALIDAdES hidroelétricas da AMazônia}

Destacamos no Mapa 1 a abrangência das hidroelétricas do MacroZEE em face à Amazônia brasileira, ao que sublinhamos, também, a potencialidade de expropriação e desterritorialização dos povos e comunidades tradicionais amazônicas. Municiados de recursos legais (território normado) e articulados a um "esquema de proteção nativo" das políticas governamentais, oferecem-se audiências e consultas públicas como os únicos espaços e possibilidades de deliberação direta para com

\footnotetext{
${ }^{8}$ Cf. Almeida, Alfredo Wagner B. de, na Conferência de abertura 28 ${ }^{a}$ RBA na PUC-SP, no dia 2 de julho de 2012, os códigos em pauta de recodificação são os códigos Florestal (1965), Mineração (1967), Processo Civil (1973), Processo Penal (1941), Processo Eleitoral (1965), Comercial (1850), Defesa do Consumidor (1990), Ciência e Tecnologia e Recursos Hídricos (código das águas). www.antropologiasocial.com.br.

${ }^{9}$ O Decreto Federal 7.378/2010, aprovou o Macrozoneamento Ecológico-Econômico (MacroZEE) da Amazônia Legal, passa a compor a "agenda do desenvolvimento regional". Tratam das "as estratégias que reposicionam na Amazônia a vanguarda da transição para a sustentabilidade". Em nosso ponto de vista seria o modo de vida dos povos comunidades tradicionais amazônicas versus o "firewall" que o governo e as empresas acionam.
} 


\section{Cartografia das hidroestratégias na Amazônia brasileira}

os grupos atingidos pelas hidroelétricas (território como norma). Sob esta ótica, o capital industrial-hidroelétrico (na forma de grandes consórcios) tem assegurado os mecanismos de expropriação e desterritorialização das comunidades atingidas pelas barragens, convergindo a relação direito e território ou direito territorial no processo social.

Conforme informações do Ministério do Meio Ambiente (MMA, $2017)^{10}$, sobre estratégias de transição para a sustentabilidade do MacroZEE da Amazônia Legal, as observamos como políticas que tratam de estratégias flexíveis, um cordão de blindagem flexivel sob quais implementam grandes projetos que tendem, como já afirmamos, a desterritorializar povos e comunidades tradicionais amazônicas, encobrindo os elementos e signos mais básicos das territorialidades dessas comunidades, a exemplo das roças como atividade produtiva e cultural, de inscrição territorial ${ }^{11}$.

Observamos no Mapa 1 a localização no MacroZEE da Amazônia Legal das "unidades territoriais e estratégias", modelo adotado pelas "estratégias de transposição para a sustentabilidade", que designamos "uma proteção possível”, ou seja, o resguardo oficial pretendido do "coração florestal". Este instrumento, a nosso ver, segue uma rotina equivalente a definir estágios e áreas de investimentos e acessos aos recursos territoriais estratégicos. Cada item/área tem uma função específica (vide indicação detalhada das legendas na Figura 3), para configurar a demanda de ação no MacroZEE e viabilizar um cenário de hidroelétricas.

Chamamos atenção para a área hachurada com fundo em vermetho claro, denominada de "Contenção das Frentes de Expansão com Áreas Protegidas e Usos Alternativos” (observar legenda da Figura 3). Nesta observação, a área em destaque relaciona e concentra algumas hidroelétricas e outras em projetos de infraestrutura planejados. Se cartografarmos outros grandes projetos na distribuição do MacroZEE, teríamos a mineração em larga escala, mesmo na área chamada de coração florestal. Listamos a imagem das insígnias do MacroZEE conforme sítio

\footnotetext{
${ }^{10}$ Disponível em: www.mma.gov.br/estruturas/ascom_boletins/_arquivos/24_03_macro zee_08_83.pdf.

${ }^{11}$ Cf. Lima, Luís Augusto P. em A roça como categoria de análise e afirmação identitária: Estudo da relação dinâmica de resistência e garantia do território em situações sociais referidas a quilombolas e indígenas. Dissertação 2015 - Universidade Estadual do Maranhão (UEMA). Sublinhamos que se trata de uma das atividades mais presentes e praticadas pelas comunidades tradicionais ao longo dos territórios amazônicos.
} 
na internet do Ministério do Meio Ambiente referidas ao Mapa 1, para que se atente aos textos relacionados. Podemos considerar uma leitura espacial das hidroelétricas que seguem o ritmo das construções determinadas pelo MacroZEE.

Remetendo ao Mapa 1 e a legenda (Figura 3) podemos argumentar que se trata de um "firewall", um "muro de fogo" em sua tradução direta, uma proteção aos grandes projetos alocados na Amazônia para as ações não conciliadas aos investimentos desses projetos, conforme se observa na Figura 3. Haja vista que as ações não conciliadas podem ser situadas como as mobilizações sociais realizadas por povos e comunidades tradicionais amazônicas frente a esses grandes projetos que estão sob a proteção vista na legenda MacroZEE.

Salientamos que sob essa proteção, firewall, os consórcios e empresas ditos responsáveis pelas obras transpõem e adquirem as licenças ambientais, de construção e operação para as hidroelétricas. Ou seja, o MacroZEE já dispõe de "permissão" inicial para a implantação desses projetos segundo as estratégias de transição para a sustentabilidade listadas nas insígnias. Todo o processo será viabilizado, por que os limites das unidades territoriais e estratégias (Figura 3) condicionam tais projetos, até sob argumentos dos Estudos de Impactos Ambientais (EIA) e dos Relatórios de Impactos Ambientais (RIMA). Ao ponto que para as mobilizações de povos e comunidades tradicionais, situam audiências e consultas que se desdobram, posteriormente, em compensações que não condizem com a realidade das comunidades tradicionais. 


\section{Cartografia das hidroestratégias na Amazônia brasileira}

Mapa 1 - Amazônia brasileira e o MacroZEE.

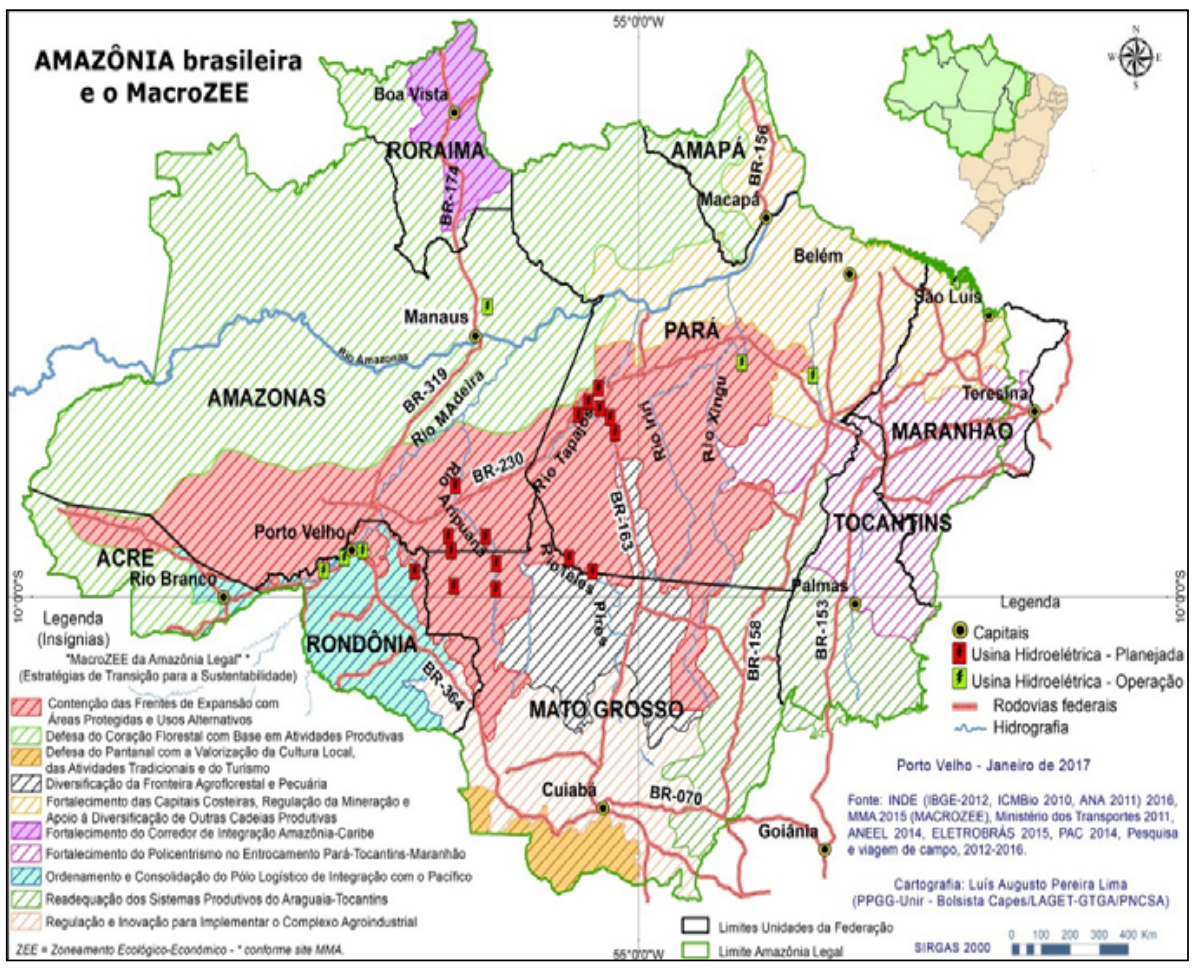

Fonte: Elaborado pelos autores, 2017. 
Geografia, território e sociedade na Amazônia

Figura 3 - Insígnias - Legenda do MacroZEE 2010.

\begin{tabular}{|l|}
\hline Contenção das Frentes de Expansão com \\
Áreas Protegidas e Usos Alternativos \\
Defesa do Coração Florestal com Base em Atividades Produtivas \\
Defesa do Pantanal com a Valorização da Cultura Local, \\
das Atividades Tradicionais e do Turismo \\
Diversificação da Fronteira Agroflorestal e Pecuária \\
Fortalecimento das Capitais Costeiras, Regulação da Mineração e \\
Apoio à Diversificação de Outras Cadeias Produtivas \\
Fortalecimento do Corredor de Integração Amazônia-Caribe \\
Fortalecimento do Policentrismo no Entrocamento Pará-Tocantins-Maranhão \\
Ordenamento e Consolidação do Pólo Logístico de Integração com o Pacífico \\
Readequação dos Sistemas Produtivos do Araguaia-Tocantins \\
Regulação e Inovação para Implementar o Complexo Agroindustrial
\end{tabular}

Fonte: MMA, 2017. Adaptado pelos autores.

Nesse prisma, há na Amazônia brasileira um processo particularmente intenso de transformação referente a posse, uso e apropriação de território (Mesquita, 2011). Conduz a interesses financeiros "internos" sobre o modo de vida de povos e comunidades tradicionais amazônicas, alvos de um afastamento social dos recursos hídricos, dos rios, enfim, do universo fluvial e florestal, do seu território e cotidiano, remetendo-os aos aglomerados urbanos, principalmente às periferias das cidades.

Subentende-se que este afastamento ou essa trama de apropriação do universo hídrico e florestal da Amazônia já constava nos "planos" ou no "Plano 2010", de transformação da Amazônia em expropriação hídrica, que fora "vazado" ou liberado ao público em 1987, apresentando a intenção do governo brasileiro e a extensão plena dos planos hídricos para Amazônia (Fearnside, 2015). Podemos então constatar que esses planos hidroestratégicos estavam em pauta e consolidados aos grandes projetos na medida em que os recursos financeiros estivessem disponíveis e "protegidos" para viabilidade, execução e operação.

A região Amazônica tem seu "firewall" ativo pelo estado brasileiro, servindo aos grandes projetos e empresas, sob os slogans da "sustentabilidade" economicamente viável e legislação "a ser adequada" na implantação e operação, rótulos de propaganda com chamariz ao social 


\section{Cartografia das hidroestratégias na Amazônia brasileira}

e ao ambiental ${ }^{12}$. Os territórios referidos sob as transformações e os significados complexos situam a dinâmica do que os converge na Amazônia brasileira a uma potencialidade para a construção de hidroelétricas. Uma contínua apropriação dos recursos e dos territórios por megaprojetos oriundos de políticas governamentais, a exemplo do Programa de Aceleração do Crescimento (PAC).

Assim, por se tratar de uma região potencialmente "protegida" que compreende interesses estratégicos, recursos naturais e áreas (terra), ou novas áreas, também tem se convertido em discursos ambientalistas face as agendas do Estado brasileiro. Uma vez que se aprofunda a exploração de recursos e a expropriação e uso do território, e com o capital "protegido" das ações não conciliadas, destrói e subjuga os direitos sociais e territoriais.

Em referência às insígnias da legenda (Figura 3) cartografadas no Mapa 1, projeta-se como uma função estratégica de mercado. Como referência ao que argumentamos, a área sublinhada de "Contenção das Frentes de Expansão com Áreas Protegidas e Usos Alternativos” compreende os locais onde estão assentados os principais empreendimentos hidroelétricos na Amazônia brasileira, comparando o Mapa 1 e o Mapa 2, mais adiante.

Tendo em vista não incluirmos em nossos mapas todos os grandes projetos na Amazônia, mas considerando as usinas hidroelétricas, observa-se que esta pretendida "Contenção" já comporta as usinas do rio Madeira, do rio Tapajós e do rio Xingu, entre operação, em obras e planejadas um tanto convergente ao que representa o Plano IIRSA ${ }^{13}$, de integrar completamente a América do Sul.

No entanto, essa possível faixa de contenção concentra uma gama de situações sociais referidas aos indígenas, quilombolas, pescadores, ribeirinhos, extrativistas e tantos outros grupos que resistem a essa "proteção" submetida a uma dita "potencialidade". Por outro lado, entendemos que "a resultante é uma Amazônia desigual, pobre e vulnerável, onde o processo de exclusão social avança velozmente apesar dos embates

\footnotetext{
${ }^{12}$ Por exemplo, em sentido contrário, seguindo essa tendência do slogan "sustentável", o site www.santonioenergia.com.br (ago-2017) divulga que a Hidroelétrica Santo Energia é a "quarta maior do Brasil em geração efetiva de energia e a primeira do mundo em sustentabilidade, reconhecida pelo IHA - International Hidropower Association”.

${ }^{13}$ Iniciativa para a Integração da Infraestrutura Regional Sul-Americana (Almeida; Carvalho, 2009).
} 
e confrontos que emergem diuturnamente contra esse estado de coisa" (Mesquita, 2011, p. 7). Significa dizer que tais desigualdades e vulnerabilidades recaem, principalmente, sobre os povos e comunidades tradicionais amazônicas, cujas mobilizações constituem um modo alternativo para reivindicar seus direitos expropriados.

Mapa 2 - Amazônia reduzida ao Coração florestal.

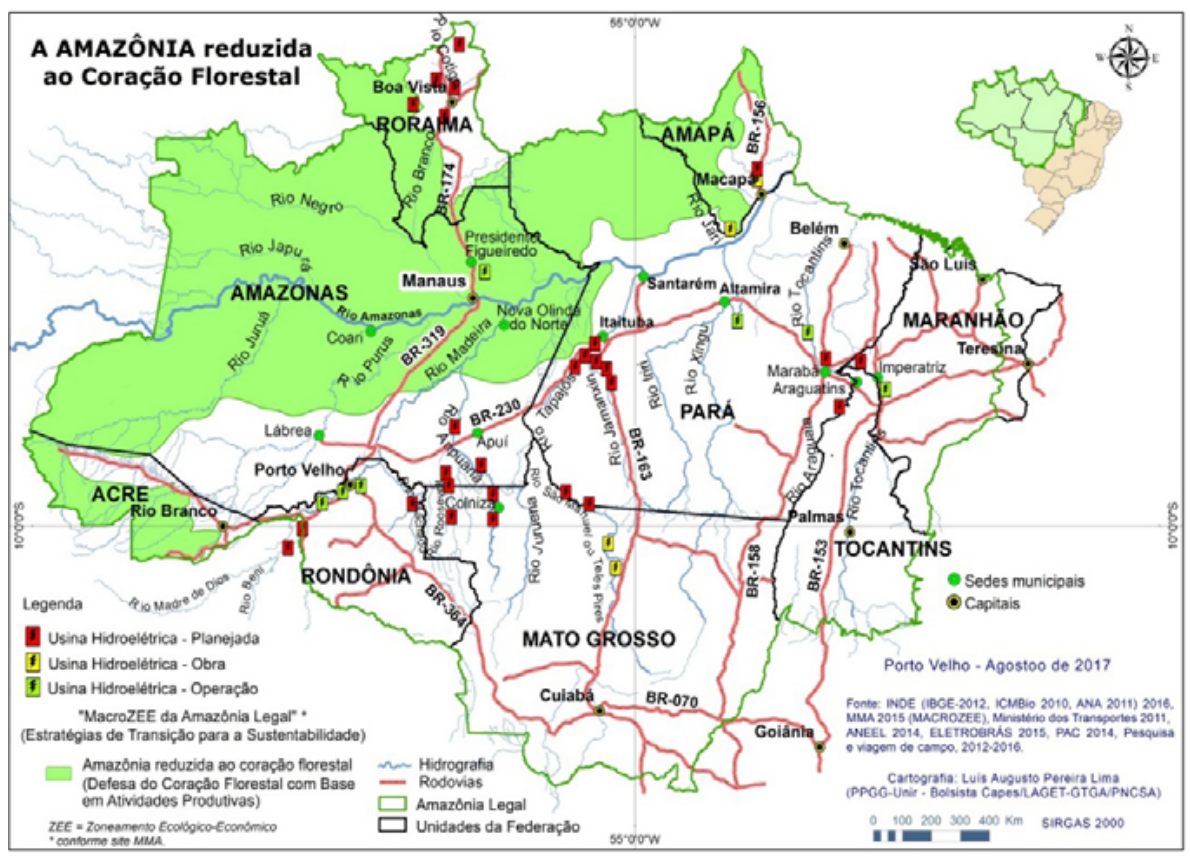

Fonte: Elaborado pelos autores, 2017.

Esse contexto nos oportuna uma ilustração geométrica como recurso analítico, condizente com a imagem de um triângulo nomeado por escaleno - ângulos e lados desiguais - e a premissa de resultados desiguais aos povos e comunidades tradicionais amazônicas, sob o qual se projeta à Amazônia uma potencialidade das hidroelétricas. A visão de um território composto, principalmente por hidroelétricas, constitui uma ação calculada e planejada sob a adaptação das normas territoriais. Ao que mencionamos, observa-se uma conexão territorial das hidroelétricas, localizadas ou concentradas no que poderíamos citar como a ilustração que hora imaginamos no Mapa 2, referido de escaleno. Tomemos como 


\section{Cartografia das hidroestratégias na Amazônia brasileira}

referência o meridiano 55 do mapa, de Santarém (PA), sentido Norte/ Sul até o paralelo 10; deste ponto até a cidade de Rio Branco (AC) e fechamos esta ponta em sentido diagonal até Santarém (PA), ou tomando como referência um trecho da BR-230, teremos o mencionado escaleno. Uma porção que aglutina hidroelétricas de forma a fomentar rios em uma ação potencial para a construção de tais projetos.

Observa-se que neste recorte as propriedades dos rios amazônicos para a geração de energia elétrica seguem uma ordem cronológica e territorial das bacias hidrográficas. Desde as construções de Balbina (AM) e Tucuruí (PA), como indica Fritzen (2016), há nessa última década expansão do macrossistema elétrico para aproveitamento hidroelétrico em vários rios da bacia amazônica, o que incluem o rio Tapajós, o rio Madeira, com as hidroelétricas de Jirau e Santo Antônio, o rio Xingu, com a hidroelétrica de Belo Monte. Pontualmente, as três referências assinaladas por Fritzen se encontram em três grandes rios: Tapajós (Itaituba-PA), Madeira (Porto Velho-RO) e Xingu (Altamira-PA). Entretanto, ainda há outras bacias, como a do rio Aripuanã que agrega o rio Roosevelt, entre Apuí (AM) e Colniza (MT), com a previsão de sete (07) hidroelétricas. Essa concentração e expansão das hidroelétricas compõem o cenário amazônico em longo prazo, haja vista que o "Plano 2010" já listava incluindo essas em 1987, prevendo até então, 79 UHEs na Amazônia independente das datas projetadas para a construção das usinas (Fearnside, 2015).

De antemão, o Mapa 2 apresenta a Amazônia reduzida a uma porção chamada de "Coração Florestal", mas ainda pode ser aprimorado e tecnicamente enriquecido para evidenciar as faixas de proteção que estão concebendo/projetando o avanço de megaprojetos oriundos de políticas governamentais. Contudo, verifica-se no mapa as rodovias e rios referidos aos locais aproximados das usinas, projetam o que referimos de uma cartografia das potencialidades para as hidroelétricas em sua dimensão amazônica, dado a logística que incrementa valor estratégico a esses locais. Apresenta-se (Mapa 2) o contexto hidroelétrico disponível entrelaçado pelas rodovias federais e os rios amazônicos, cuja representação cartográfica reflete o quantitativo das usinas a serem construídas em torno do dito "coração florestal", em obras e instaladas na Amazônia brasileira, indicando o processo de hidroestratégias.

Ao observarmos a faixa sul do estado do Amazonas, sudoeste do Pará, norte de Mato Grosso e nordeste de Rondônia (Mapa 2), temos o primeiro aglomerado de UHE nesta porção amazônica. Por conseguinte, o segundo conjunto de UHE se projeta no oeste do Pará, nas adjacências 


\section{Geografia, território e sociedade na Amazônia}

de Itaituba, na bacia do rio Tapajós. O terceiro grupo de usinas encontra-se nas proximidades da região conhecida como "Bico do Papagaio", entre Marabá (PA), Imperatriz (MA) e Araguatins (TO), e o quarto ponto de concentração está mais ao norte, em Roraima. É expressivo esse "conjunto" de hidroelétricas considerando que as dificuldades financeiras do governo brasileiro tenham forçado, repetidamente, alterações dos planos para construção das barragens e a escala planejada, independente da data de conclusão de cada represa, tem permanecido inalterada (Fearnside, 2015).

Estes locais cartografados, seguindo essa escala planejada, somam cerca de duas dezenas de usinas planejadas ou em obras. Localizam-se na faixa de proteção permitida, "distante" do "coração florestal". Dentre todas as insígnias listadas na espacialidade do MacroZEE, apenas no Pantanal se refere a "atividades tradicionais". Percebemos que este sistema de proteção é para uma possível distinção e contensão de conflitos sociais referentes aos povos e comunidades tradicionais amazônicas, e indicar áreas com atividades comerciais ou industriais, qual seja a natureza com a disposição resguardada do fornecimento de energia.

Destacamos no Mapa 2, em fundo verde, o que o MMA apresenta como "Defesa do Coração Florestal com Base em Atividades Produtivas". Uma proposta governamental que articula a inserção de grandes projetos no entorno dessa porção verde. É destacado o registro das usinas hidroelétricas planejadas ou em obras fora desse limite, em seu entorno. Haja vista que o gás de Itapiranga, Silves e Itacoatiara (AM), o petróleo e gás de Urucu em Coari (AM), a mineração em Presidente Figueiredo e Nova Olinda do Norte (AM) não "devem representar nenhuma ameaça ao coração florestal” ou os conflitos sociais e ambientais foram harmonizados? Em se tratando de usinas hidroelétricas, Balbina, em Presidente Figueiredo (AM), também constitui esse efeito. Convém observar que significa, na realidade, a Amazônia como a conhecemos ser reduzida ao que referem como "coração florestal"?

Consoante aos itens elencados no mapa, a relação dos projetos hidroelétricos indica as hidroestratégias nos rios Madeira, Roosevelt, Aripuanã, Tapajós, Jamanxin, Iriri, São Manuel ou Teles Pires, Xingu, Branco, Cotigo, Machado, Jari, Araguaia e Tocantins, como expoentes da territorialização das usinas hidroelétricas na Amazônia brasileira. E, especificamente como conectores, indica-se as rodovias federais (BR) que fazem a conexão do território, criando uma dinâmica de fluxo mercantil, de relações sociais e de poder, que envolvem trabalhadores, empresas e 


\section{Cartografia das hidroestratégias na Amazônia brasileira}

o próprio governo brasileiro. As rodovias propiciam a chegada e a saída de trabalhadores chamados de "barrageiros" ou aqueles trabalhadores vistos como "trecheiros", que se amontoam nas pequenas e médias cidades, em busca de trabalhos oriundos desses projetos hidroelétricos.

No Mapa 2, observa-se esses conectores a partir da rodovia BR230, nomeada de Transamazônica, do seu fim provisório em Lábrea (AM), que cruza a BR-319 - que conecta Manaus (AM) à Porto Velho (RO) - passando por Humaitá e Apuí, no Amazonas, indo por Itaituba, Altamira, descendo até Marabá, no Pará, como se desenhasse um "V" invertido e segue adiante. Em outro sentido, temos a BR-364 que cruza toda a extensão de Rondônia, saindo de Porto Velho até Cuiabá, no Mato Grosso. Desse ponto, em sentido norte, de Cuiabá (MT), a BR163 segue até Itaituba (PA), ao porto de Miritituba, podendo conectar-se até Santarém. Esta projeção poderia ser uma representação não calcula$\mathrm{da}$, mas esse percurso prioriza a conexão das hidroelétricas numa linha de apropriação de territórios e recursos naturais ainda não estimados.

Além de ampliar o fluxo da pecuária e do agronegócio (grãos) em quase todas as áreas fora do "coração florestal", intercalando com grande parte os rios barrados ou transformados em hidrovias, é de se imaginar essas rodovias em condições plenas de uso e transporte, incluindo aqui a BR-319, que parece estar à margem desse corredor, mas especificamente esta rodovia, com asfalto/pavimentada, poderia transformar toda a Amazônia brasileira, de uma só vez, em outra potencialidade à exploração econômica.

Vê-se, ainda nesta reflexão, uma forma integrada, tanto quanto as rodovias aos rios, essas hidroestratégias às articulações políticas, econômicas e sociais, pois transitam na atual conjuntura como uma normalidade "permitida" para alcançar recursos energéticos que expropriam direitos e territórios em uma sociedade marcada por desigualdades sociais. Porém, a dinâmica exercida sobre nós é como se tivéssemos imergido em um surto econômico que continua, com usinas em fase de construção e de projeto, e que vai desencadeando situações inéditas em cada local para grupos humanos que ali residem, trabalham e convivem com as obras e as usinas; um surto com efeitos que vão se sobrepondo na dinâmica dos rios e das bacias fluviais (Sevá Filho, 2008).

Consoante ao que tramamos, as evidências dessa cartografia das hidroestratégias estão em toda bacia amazônica; poderia ser pan-amazônica, haja vista que nesta reflexão não abrangemos tal proporção, contudo 


\section{Geografia, território e sociedade na Amazônia}

não há um encerramento dessa discussão, mas uma fonte inicial para outras compreensões e debates sobre hidroelétricas na Amazônia brasileira.

\section{CONSIDERAÇÕES FINAIS}

Se considerarmos a transformação da Amazônia sob a lógica das hidroestratégias interconectadas por rios, rodovias e linhas de transmissão, os territórios na Amazônia, nos quais povos e comunidades tradicionais constituem suas práticas e saberes, aproximam-se das referências permanentes das normativas territoriais e das relações de poder instaladas pelas empresas e mediadas pelo Estado.

Embora possam ser revelados ritmos acelerados, essas hidroestratégias também podem ser demasiadamente lentas ou morosas quanto ao lidarem com as compensações atribuídas aos povos e comunidades tradicionais amazônicas. Essa disposição cartográfica ao qual indicamos se insere e expõe um possível "território das hidroelétricas" em sua apropriação espacial, projetando desigualdades, expropriando direitos e territórios, significados e autonomias.

Se por um lado possa parecer hidroestratégias descontínuas em função das obras distantes e em locais afastados na Amazônia, o conjunto de hidroelétricas que situamos nos mapas estão em uma conexão planejada, pois não foram deixadas ao acaso geográfico. Obviamente mais empresas e outros grandes projetos entrarão em pauta, a exemplo da mineração, se avolumando aos que já existem na Amazônia, tomando forma de uma "potencialidade para as hidroelétricas".

Trata-se de uma visão devastadora para os territórios tradicionalmente ocupados, visto que a territorialidade do capital hidroelétrico institui regras de uso do território, outras normas. A partir dessa perspectiva, sugerimos que há uma territorialidade do capital hidroelétrico que tende a subordinar as territorialidades dos grupos sociais, como aconteceu com as comunidades do rio Madeira. Esse nos parece ser o cenário que se erige na Amazônia brasileira, uma bacia hidrográfica em disputas. 


\section{REFERÊNCIAS}

ALMEIDA, A. W. B. de, e CARVALHO, G. (Orgs.) O Plano IIRSA na visão da sociedade civil. Belém: Federação de Órgãos para Assistência Social e Educacional/FASE; Observatório Comova/UFPA, 2009.

ANTAS Jr., Ricardo Mendes. Território e regulação: espaço geográfico, fonte material e

Becker, Bertha K. Amazônia: geopolítica na virada do III milênio. Rio de Janeiro: Garamond, 2006.

FEARNSIDE, Philip. Hidrelétricas na Amazônia: impactos ambientais e sociais na tomada de decisões sobre grandes obras. - Manaus: Editora do INPA, 2015. Cap. 1 p. 9-37.

FRITZEN, Maycon. Uso do território e o macrossistema elétrico nacional: a geração hidrelétrica de pequeno porte. In: Encontro Nacional de Geógrafos - XVIII ENG, São Luís, 2016.

GOTTMANN, Jean. The significance of territory. Charlottesville: University Press of Virginia, 1973.

LIMA, Luís Augusto Pereira. A roça como categoria de análise e de afirmação identitária: estudo da relação dinâmica de resistência e garantia do território em situações sociais referidas a quilombolas e indígenas. São Luiz, 2015. Dissertação (Mestrado Cartografia Social e Política da Amazônia), Universidade Estadual do Maranhão (UEMA).

MESQUITA, Benjamin A. de. Conflitos Territoriais na Amazônia na "Era do Capital”. In: Meio Ambiente, território \& Práticas Jurídicas: enredos em conflito. Joaquim Shiraishi Neto et al. (Orgs.) São Luís: EDUFMA, 2011.

MMA. Boletim: MACROZEE da Amazônia Legal. Estratégias de transição para a sustentabilidade (2010). Disponível em www.mma.gov. br/estru turas/ascom_boletins/_arquivos/24_03_macrozee_08_83.pdf. Acesso em: 20 ago. 2017.

PORTO-GONÇALVES, Carlos Walter. A reinvenção dos territórios: a experiência latino-americana e caribenha. In: CECEÑA, Ana Esther (org.). Los desafios de las emancipaciones en um contexto militarizado. Buenos Aires: CLACSO, 2006. p. 151-197.

SANTOS, Milton. A natureza do espaço: Técnicas e Tempo, Razão e Emoção. São Paulo: Hucitec, 1996.

SAQUET, Marcos A. Abordagens e concepções de território. São Paulo: Expressão Popular, 2007. 
SEVÁ FILHO, Arsênio Oswaldo. Estranhas catedrais. Notas sobre o capital hidrelétrico, a Natureza e a Sociedade. Revista Ciência e Cultura. Núcleo Temático - Energia, Ambiente e Sociedade, v. 60 n. 3 São Paulo, setembro de 2008.

SILVA, Ricardo Gilson da Costa. Hidrelétricas do Madeira e a nova geografia de Porto Velho. Tudorondonia.com, Jornal Eletrônico Independente, Porto Velho, p. 1, 23 abr. 2015. Disponível em: www.tudorondonia.com.br/noticias/hidreletricas-do-madeira-e-a-nova-geografia-de-porto-velho,51690.shtml. 


\section{Agronegócio PRODUZ COMMODITIES E AGRICULTURA \\ CAMPONESA PRODUZ ALIMENTOS: O CASO DA \\ AMAZÔNIA BRASILEIRA}

Francilene Sales da Conceição"

Wesley Henrique Garcia e Silva**

\section{INTRODUÇÃO}

Este artigo tem como objetivo realizar uma análise comparativa entre a produção desenvolvida pela agricultura capitalista (agronegócio) e a agricultura camponesa (campesinato) na Amazônia brasileira. O recorte espacial será a Amazônia Brasileira, especificamente nos estados de Rondônia, Pará, Amapá e Roraima, no período que compreende 2010 a 2019.

O critério de escolha desses estados se deu em virtude da apresentação no avanço da produção agrícola (soja e milho) e pela expressiva espacialização e agravamento dos conflitos agrários/territoriais sobre terras/territórios do campesinato amazônico. Como procedimentos metodológicos, optou-se pela análise de dados estatísticos e secundários do Instituto Brasileiro de Geografia Estatística (IBGE), realizado na Pesquisa Municipal Agrícola (PAM) e por meio de entrevistas semiestruturadas (perguntas abertas e fechadas) com camponeses/camponesas, instituições e organizações. Para coleta de informações, utilizou-se um gravador de voz e, posteriormente, foi feita a transcrição dos áudios, bem como o uso do caderno de campo, para registar as informações (obtidas oralmente e por meio de observações), importantes na pesquisa.

O agronegócio e campesinato são aqui entendidos como dois modos de produção e classes sociais, que possuem intencionalidades 


\section{Geografia, território e sociedade na Amazônia}

completamente diferentes e que estão em disputas, criando múltiplas estratégias espaciais e territoriais. A produção e reprodução da agricultura camponesa visa garantir a recriação social da unidade familiar, contribuindo com a subsistência e renda da família, uma estratégia de resistência frente às imposições das forças coercitivas moderno-hegemônicas. Enquanto a agricultura capitalista (agronegócio) tem a finalidade de expandir a produção/distribuição/circulação/consumo agrícola, cristalizando conflitos agrários e territoriais sobre os territórios dos povos amazônicos, voltando-se globalmente aos mercados agroexportadores, práticas estas realizadas pelas grandes tradings.

Este estudo foi categorizado em três momentos, além da introdução e considerações finais. O primeiro trata de um debate teórico-metodológico das dinâmicas agrária e territorial, estabelecida entre o agronegócio e o campesinato no espaço amazônico. O segundo compreende as distintas formas e estratégias de produção e reprodução da agricultura capitalista (agronegócio) e agricultura camponesa (campesinato). No terceiro, desvela-se a análise e sistematização dos dados qualitativos e quantitativos, a partir de uma análise comparativa sobre as formas de produção não familiar (capitalista) e a produção familiar (camponesa). Nesse sentido, a análise comparativa que define o agronegócio como produtor de commodities e a agricultura camponesa como produtora de alimentos, demonstram disputas territoriais entre duas formas de produção e classes sociais que possuem interesses e intencionalidades díspares na sua totalidade.

\section{DINÂMICAS AGRÁRIAS E TERRITORIAIS ENTRE AGRONEGÓCIO E CAMPESINATO: UM DEBATE TEÓRICO SOBRE OS PROCESSOS DE PRODUÇÃo NA AMAZÔNIA}

No contexto da globalização neoliberal, o agronegócio se expressa como um modelo benéfico, único, universal e moderno, que visa promover o "desenvolvimento" do país (Fernandes, 2014). Entretanto, este é um projeto hegemônico violento, que propõe produzir mercadorias em larga escala e incorporá-lo em um circuito agroexportador globalizado, mercantilizar/pressionar as terras/territórios compostos de recursos/bens naturais e por uma diversidade de vidas, compondo um mosaico de múltiplas territorialidades dos povos amazônicos (Haesbaert, 2004; Costa Silva e Lima, 2020).

Nesse processo dialético, a natureza se globaliza conflituosamente e os povos amazônicos (Povos Indígenas e Comunidades Tradicio- 


\section{Agronegócio produz commodities e agricultura camponesa produz alimentos}

nais) são colocados numa posição marginal e espoliadora, em virtude da hegemonia da natureza da globalização perversa (Santos, 2000; Costa Silva, 2013; Costa Silva e Lima 2020) materializado no plano expansivo do agronegócio latifundiário, cuja espacialização resulta em uma cartografia dos impactos e conflitos agrários e territoriais (Michalski e Costa Silva, 2020).

Essas dinâmicas territoriais preexistentes no espaço agrário amazônico, que envolve campesinato e agronegócio, são reflexos de encontros e desencontros (Martins, 2014; Conceição, Ribeiro e Costa Silva, 2019) entre as duas formas/modelos de produção, eclodindo em territórios paradoxais em disputas. Nesse sentido, uns dos apontamentos de tais relações contraditórias, estabelecidas entre agronegócio e campesinato, se dão a partir das formas de produção, pois a agricultura capitalista tenta sobrepor e instaurar sua lógica violenta, excludente e marginalizadora sobre a agricultura camponesa, incorporando geograficamente numa escala-mundo.

Tal situação geográfica deve ser entendida como um processo multiescalar de conversão dos espaços agrícolas da produção familiar em campo de expansão econômica do capital globalizado, que adicionado à produção de commodities agrícolas se configura em espaços da globalização (Costa Silva e Conceição, 2017, p. 55).

Os frequentes espaços da globalização operante nos lugares colocam em confronto a produção familiar e a produção de commodities. As formas produtivas entre campesinato e capitalismo (agronegócio) possuem intencionalidades diferentes, porque as "condições particulares estabelecidas tanto no plano da distribuição quanto no plano da troca enquanto instâncias mediadoras distintas da produção e do consumo" (Costa, 2012, p. 48), cristalizam-se em ações macro escalares, cujo ponto de partida é a produção, passando pelo processo de distribuição e circulação ou troca e por fim, solidifica-se no consumo.

De fato, o movimento espacial do capital, ao se expandir no campo amazônico, produzindo mercadorias de exportação (commodities), delibera relações conflituosas no espaço da produção campesinato, subordinando coercitivamente o tipo de produção local (familiar) a uma forma de produção global. A territorialização do capital no campo tem formulado novos rearranjos espaciais, cooperado substantivamente 


\section{Geografia, território e sociedade na Amazônia}

no avanço da produção de mercadorias e na redução da produção de alimentos, na qual:

Constatam-se transformações no espaço agrário estimuladas pelo capital globalizado, instaurando crises no uso do território, quando o espaço do campesinato diminui e o espaço do agronegócio avança. O entendimento do movimento do capital se realizando no ambiente local/regional a partir da produção de mercadorias e de domínio do território nos indica os arranjos espaciais emergentes que atravessam as regiões, sendo, pois, comandados de diferentes lugares, cujas hierarquias políticas, técnicas e informacionais se manifestam conflituosamente no espaço da produção (Costa Silva e Conceição, 2017, p. 56).

Os investimentos solidários, especializados e organizacionais, destinados ao meio técnico-científico-informacional na agricultura capitalista (Santos, 2012; Costa Silva, 2013) e a formulação de políticas territoriais para o agronegócio, identificado por meio da produção agrícola (soja e milho) e sistemas logísticos (rodovias, hidrovias, ferrovias e portos), tem promovido metamorfoses socioespaciais e gerado inúmeros conflitos.

O campesinato e o agronegócio, entendidos como dois modelos de produção (Figura 1) e classes sociais que diferem entre si e estão em constantes disputas territoriais, na qual atingem escalas e funcionalidades divergentes, configuram-se como territórios dos conflitos agrários. Os incentivos e investimentos em pesquisas técnico-científicas, para a territorialização do capital no espaço agrário da Amazônia, resultou na expansão e desenvolvimento da produção agrícola de commodities. Além do mais, as formulações de políticas públicas territoriais se configuraram na materialização de redes logísticas, portos e no avanço do cultivo agrícola, incorporados no circuito de produção, distribuição, circulação e consumo de mercadorias globalizadas.

Esse processo socioespacial e socioterritorial é o indicativo da legitimação da propriedade privada, concentração fundiária e grilagem de terras no campo amazônico. A produção, que antes era tida como tradicional/sobrevivência desenvolvidas pelos próprios povos amazônicos, vem diminuindo e sofrendo pressões e coação territorial, dando lugar a uma produção verticalizada de caráter global. 


\section{Agronegócio produz commodities e agricultura camponesa produz alimentos}

Figura 1 - Diferenças das formas de produção do agronegócio e campesinato.

\begin{tabular}{|l|l|}
\hline Agricultura do agronegócio & Agricultura camponesa \\
\hline Monocultura & Policultura \\
\hline $\begin{array}{l}\text { Monoprodutiva e controlada } \\
\text { pelos mercados }\end{array}$ & Poliprodutiva e autônoma \\
\hline $\begin{array}{l}\text { Utilização de maquinários e } \\
\text { investimentos tecnologia, insu- } \\
\text { mos e pesticidas (uso intensivo } \\
\text { de agrotóxicos) }\end{array}$ & $\begin{array}{l}\text { Utilização de suas próprias técnicas tradi- } \\
\text { cionais e livres de agrotóxicos (agroextra- } \\
\text { tivista e agroecológica) }\end{array}$ \\
\hline $\begin{array}{l}\text { Trabalho especializado e prole- } \\
\text { tarizado (poucos trabalhadores } \\
\text { (braços) para operar os maqui- } \\
\text { nários em grandes extensões de } \\
\text { terra) }\end{array}$ & $\begin{array}{l}\text { Trabalho familiar (muitos braços e bocas } \\
\text { para trabalhar no cultivo das roças e } \\
\text { cia) }\end{array}$ \\
\hline “Segurança” alimentar produtivos e consumo/subsistên- \\
\hline $\begin{array}{l}\text { Escala nacional/global } \\
\text { comercialização pelos produto- } \\
\text { res (fazendeiros do agronegócio) } \\
\text { para/pelas empresas multi/trans- } \\
\text { nacionais (tradings) }\end{array}$ & $\begin{array}{l}\text { Comercialização pelos próprios agriculto- } \\
\text { res nas feiras e comércios locais/regionais } \\
\text { no campo ou cidade }\end{array}$ \\
\hline $\begin{array}{l}\text { Produtora de mercadorias (com- } \\
\text { modities) }\end{array}$ & Produtora de alimentos \\
\hline $\begin{array}{l}\text { Presença de conflitos agrários e } \\
\text { territoriais }\end{array}$ & $\begin{array}{l}\text { Ausência de conflitos agrários e territo- } \\
\text { riais }\end{array}$ \\
\hline
\end{tabular}

Fonte: Trabalho de campo, 2020. Organização: Autores, 2021.

O agronegócio é produtor de mercadorias globalizadas em larga escala e que estabelece um circuito vertical de tamanha complexidade socioespacial, cristalizado na produção agroexportadora de commodities, que instaura nos lugares a mercadorização de terras/territórios e a exclusão, subjugação e conflitos com as múltiplas territorialidades de povos e comunidades tradicionais amazônicas e que pressiona as áreas protegidas que vivem nas/das/para Terras, Águas e Florestas (Conceição, 2017; Conceição, Ribeiro e Costa Silva, 2019; Conceição e Costa Silva, 2020). 


\section{Geografia, território e sociedade na Amazônia}

Por outro lado, a lógica desigual, combinada e perversa do capital global nega a produção camponesa diversificada, poliprodutiva, autônoma, agroextrativista e agroecológica, que garante a soberania alimentar, pois essa tipologia de agricultura é produtora de alimentos que contribuem com a subsistência e a renda familiar, resultando na recriação social camponesa. O processo relacional antagônico na esfera produtiva da expansão do agronegócio sobre a agricultura praticada pelo campesinato: "afeta muito a gente e eu fico muito triste de plantar e não colher pelo não respeito dos outros” (Entrevista camponesa amazônica, 2017).

Para Assis Costa (1993), ao parafrasear Chayanov, afirma que:

A família é o fundamento da economia camponesa - na sua condição de economia sem assalariamento -, uma vez que é tanto o ponto de partida quanto o objetivo da sua atividade econômica. Como única fonte de força de trabalho a família é o suposto da produção cujo objetivo nada mais é do que garantir a própria existência. A unidade camponesa é, pois, a um só tempo unidade de produção e unidade de consumo e encerra concomitantemente as funções das esferas de produção e reprodução (Costa, 1993, p. 8).

$\mathrm{Na}$ produção camponesa, a principal forma de exploração do trabalho é a da família, que garante o equilíbrio de braços e bocas (pai, mãe, filhos, agregados ou outros parentes) para a subsistência/consumo nas unidades organizativas familiares camponesas. Na produção capitalista, a exploração do trabalho se constata por meio do assalariamento, na qual o indivíduo se proletariza e o capitalista extrai a mais-valia e/ou renda da terra para gerar Mercadoria-Dinheiro-Mercadoria (M-D-M) ou Dinheiro-Mercadoria-Dinheiro (D-M-D), objetivando promover a acumulação de capital (lucro) e incorporar na lógica dos mercados mundiais agroexportadores.

A produção e a reprodução da natureza da agricultura camponesa e da agricultura capitalista (agronegócio), relacionalmente falando, é demarcada por lógicas que se opõem e por intencionalidades que não dialogam entre si. A primeira está para garantir a recriação social da unidade familiar e resistir frente às imposições das forças coercitivas moderno-hegemônicas. A segunda tem a finalidade de se reproduzir globalmente nos mercados agroexportadores, práticas estas realizadas pelas grandes tradings. Essas ações de ordem capitalista, comandadas pelas multi/transnacionais, instauram ainda nos lugares onde vivem e trabalham os povos e comunidades tradicionais amazônicas e lócus onde 


\section{Agronegócio produz commodities e agricultura camponesa produz alimentos}

se encontram as áreas protegidas, tornam-se alvos dos projetos de modernização conservadora que subjugam, criminalizam, excluem, expropriam e violentam corpos de povos amazônicos e a natureza.

O agronegócio é esse modelo econômico de "projeto desenvolvimentista", mas que carrega na sua essência e discurso, um elevado grau de perversidade, atrocidades e ações inescrupulosas. Ainda que o agronegócio imponha sua lógica excludente e contraditória, a agricultura camponesa se manifesta como grande produtora de alimentos que abastece o campo e a cidade; nos mercados locais e regionais, por meio de uma produção/estratégia diversificada, agroextrativista e agroecológica (Conceição 2017; Conceição e Costa Silva, 2020), fundamentais para a reprodução social da vida/trabalho campesino em comunidade.

ProduÇão da Agricultura Capitalista (Agronegócio) E AGRICUlTURA CAMPONESA (CAMPESINATO): ESTRATÉGIAS DE PRODUÇÃO E REPRODUÇÃO

As formas de produção (Figura 2), seja ela capitalista (agronegócio) ou camponesa, elaboram suas próprias estratégias de produção e reprodução espacial e territorial, ora no espaço agrário, ora nas cidades das florestas ou nas cidades ribeirinhas amazônicas (Trindade Júnior, 2010), como é o caso de Santarém, Belterra e Mojuí dos Campos, no Oeste paraense. Nesses municípios, a expansão da monocultura de grãos sob os territórios florestais e dos povos e comunidades tradicionais, tem revelado inúmeros conflitos e aumentado as pressões sob Unidades de Conservação (UC), Terras/Territórios Indígenas (TI), quilombolas, ribeirinhas, extrativistas e camponesas, como vem ocorrendo também nos estados de Rondônia, Amapá e Roraima. 
Figura 2 - Diferenças das estratégias de produção e reprodução: agronegócio e campesinato.

\begin{tabular}{|l|l|}
\hline \multicolumn{1}{|c|}{ Produção do Agronegócio } & \multicolumn{1}{c|}{ Produção do Campesinato } \\
\hline Commodities & Alimentos \\
\hline $\begin{array}{l}\text { Mercados globalizados e produção de } \\
\text { mercadorias para exportação }\end{array}$ & $\begin{array}{l}\text { Mercados locais e regionais para } \\
\text { comercialização e produção para } \\
\text { consumo/sustento familiar }\end{array}$ \\
\hline Produção agroexportadora & $\begin{array}{l}\text { Produção agroextrativista e agroe- } \\
\text { cológica }\end{array}$ \\
\hline $\begin{array}{l}\text { Reprodução ampliada do capital (acu- } \\
\text { mulação) }\end{array}$ & $\begin{array}{l}\text { Reprodução social da vida (subsis- } \\
\text { tência e renda familiar) }\end{array}$ \\
\hline $\begin{array}{l}\text { Cultivo agrícola, rodovias, hidrovias, } \\
\text { ferrovias e portos }\end{array}$ & $\begin{array}{l}\text { Cultivo de roças (corte-queima) e } \\
\text { prática do extrativismo da pesca, } \\
\text { caça e coleta }\end{array}$ \\
\hline $\begin{array}{l}\text { Sujeitos/agentes: latifundiários/produ- } \\
\text { tores/fazendeiros e tradings (empresas } \\
\text { multi/transnacionais) }\end{array}$ & $\begin{array}{l}\text { Sujeitos/agentes: família camponesa } \\
\text { (pai-mãe-filhos-agregados ou outros } \\
\text { parentes) }\end{array}$ \\
\hline
\end{tabular}

Fonte: Trabalho de campo, 2020. Organização: Autores, 2021.

A abertura para a territorialização do grande capital, por meio de investimentos públicos e privados e a expansão da fronteira agrícola globalizada na Amazônia, resultou no que Santos (2012) denominou de sistemas de objetos e sistemas de ações. A priori, os estudos de Rodrigues (2018) reforçam bem essa ideia conceitual miltoniana no contexto do espaço amazônico e aponta que as políticas públicas, voltadas para as redes de infraestrutura, logística (transporte) e os portos graneleiros, a exemplo do projeto do Arco Norte no estado do Pará, com expressividade para os municípios de Itaituba e Rurópolis, desvela-se em espaços da globalização e aceleração do tempo-espaço.

Esse complexo de "integração" e circuito produtivo do agronegócio, marcado por tempos rápidos (Santos, 2012), objetiva contribuir no aumento da fluidez das exportações de commodities e colocar a Amazônia na posição de competividade nos circuitos produtivos e financeiros globais (Rodrigues, 2018), caracterizando como uma região verticalizada e especializada que se torna altamente produtora e fornecedora de 


\section{Agronegócio produz commodities e agricultura camponesa produz alimentos}

mercadorias globais e tornando um espaço da acumulação ampliada do capital.

Por outro lado, as estratégias de lutas sociais e resistências dos povos amazônicos frente à produção do agronegócio, manifesta-se como permanecer e se recriar espacialmente e territorialmente na terra e no território, produzindo alimentos saudáveis.

Porque se o trabalhador rural se alimenta bem, se ele tem como viver melhor, as vezes ele vai ter mais saúde, ele vai ter condição até de estudar e tudo e se não tem saúde não se alimenta bem, não tem saúde, não tem como estudar, sabe e muitas coisa precisa, eu sei disso, mermo a gente não perde a esperança a gente continua se organizando (Entrevista STTR Belterra, 2016).

Ainda que os discursos hegemônicos queiram invisibilizar e desqualificar a produção econômica camponesa, de que não contribui com o desenvolvimento do país, é dessa agricultura poliprodutiva que consumimos e que abastece de forma diversificada os mercados e feiras-livres locais e regionais. Assim, a produção de alimentos oriunda da agricultura camponesa, utiliza de técnicas tradicionais para cultivo das roças e da prática do extrativismo (vegetal, animal e pesqueiro). Conceição (2017) denominou o perfil dessa tipologia campesinato que agrega agricultura e extrativismo, como campesinato-agroextrativista.

A vida e o trabalho desenvolvido na agricultura e no extrativismo pelo campesinato-agroextrativista consistiam "não explorado a natureza, fazia pouca terra e a gente cuidava e não era explorado e dali a gente fazia o nosso jeito de vida, do jeito que dava a gente ia se alimentando, ia caçando" (Entrevista camponês-agroextrativista, 2016). Essa fala reforça bem um modo de vida amazônico, concretizado nas Terras-Águas-Florestas (Conceição, 2017; Conceição e Costa Silva, 2020).

Além da prática do agroextrativismo ser muito praticado pelos povos e comunidades tradicionais amazônicas, principalmente pelo campesinato como iniciativa de front e (re)existências territoriais, a agroecologia surge como forma de reprodução social que exige mudanças na maneira de produzir e como resistência ao modelo de agronegócio e sistema capitalista (Guhu e Tonar, 2012).

A agroecologia é uma agricultura que não agride intensamente a natureza, ao contrário do agronegócio, que com uso da tecnologia e informação depreda a natureza e emprega elevados agroquímicos e insumos nas atividades agrícolas. Para Guhu e Tonar (2012), a agroecologia 


\section{Geografia, território e sociedade na Amazônia}

é um estilo de agricultura de base ecológica e sustentável em que está livre de transgênicos e agrotóxicos, uma estratégia política muito difundida pelos movimentos sociais camponeses, como forma de resistência ao modelo tecnológico hegemônico praticado pelo agronegócio.

$\mathrm{Na}$ Amazônia, a classe social do campesinato adota essas estratégias agroecológicas e agroextrativistas para firmar a (re)produção econômica, social, cultural, política e camponesa. Não é à toa que o campesinato amazônico enfrenta muitos problemas, principalmente no que corresponde ao acesso às políticas públicas sociais, territoriais e agrárias, que facilite o escoamento da produção e a mobilidade espacial empregada no sistema de transportes e condições de melhoramento das estradas.

Depois daquele tempo pra cá, aí foi melhorando porque as estradas foi melhorando, os transportes também foi chegando até nós e aí foi melhorando porque a gente já tinha condição em que levar a gente pra cidade né, levar a produção pra cidade (Entrevista camponês-agroextrativista, 2017).

São essas formas de (re)existências que os camponeses amazônicos têm enfrentado cotidianamente e têm lutado frente aos projetos capitalistas, que avançam sob a fronteira na região, para que assim sejam reconhecidos como sujeitos de direitos, que possam viver e trabalhar no seu território. Igualmente, os trabalhadores do campo, além de abastecer sua própria unidade familiar, por meio de sua própria subsistência, fornecem produtos agroextrativos e agroecológicos no campo ou na cidade, por meio da comercialização de sua produção, contribuindo qualitativamente com a renda das famílias camponesas.

\section{ANÁlise COMPARATIVA DA PRODUÇÃO ENTRE AGRONEGÓCIO E CAMPESI- NATO NO ESPAÇO AMAZÔNICO}

Na década de 1960, se inicia no espaço amazônico, o processo de ocupação carregado do discurso de integração nacional. Essa integração foi engendrada pelo capitalismo internacional e fomentada principalmente pelos governos militares, para efetivação do capital privado, por meio de projetos de desenvolvimento para a região, incluindo a colonização agrícola. Essas políticas incluíam desde a construção da rodovia Transamazônica e a hidrelétrica do Tucuruí no estado do Pará. 


\section{Agronegócio produz commodities e agricultura camponesa produz alimentos}

Chegada a década de 1970, especificamente em 1974 no governo do militar Ernesto Geisel, os projetos agrícolas começam a ganhar grande dimensão e maior visibilidade na Amazônia. Dentre essas condutas hegemônicas, destaca-se a incorporação expansionista da fronteira agrícola globalizada pelos sulistas para as demais regiões, incluindo o Norte do Brasil. Nesse contexto, Staevie (2018) aponta que o Polo Amazônia foi um dos programas responsáveis pelo incentivo dos fluxos migratórios voltados para a Amazônia brasileira, cuja proporção desse fenômeno era promover a ocupação e o cultivo agrícola da soja, essencialmente em Rondônia e Pará.

A territorialização do capital e a espacialização dos grãos no espaço amazônico, está arquitetado sobre a égide das crescentes culturas do milho e da soja, conforme já salientado anteriormente, em que são refletidas contraditoriamente nos territórios dos povos amazônicos, por meio de conflitos agrários e territoriais. Os investimentos de capitais destinados aos sistemas logísticos, para o escoamento de grãos em diferentes lugares da Amazônia, como é o caso dos estados de Rondônia, Pará, Amapá e Roraima. Esses estados se destacam no projeto do Arco Norte, juntamente com o estado do Maranhão, no momento em que são considerados como potenciais e viáveis para a territorialização logística e portuária, geoestratégia esta que agiliza a fluidez das mercadorias e reduz os custos dos transportes.

Em 1997, Rondônia recebeu investimentos para a hidrovia Madeira-Amazonas e a rodovia BR-364, formando o modal hidro-rodoviário (Costa Silva, 2014). Essa novidade embrionária, incorporada no território rondoniense, instaurou novos arranjos espaciais a partir da expansão da fronteira agrícola globalizada, aonde a formação de monoculturas e do circuito de exportação das commodities vai promovendo um espaço fragmentado e a formação de monopólios de poder.

Para tanto, o processo de modernização do território nacional, iniciada a partir de 1990, também chega à região amazônica e provoca transformações territoriais de ordem conflituosa. Essa política, que é voltada para uma economia de exportação, cristaliza-se numa especialização da produção agrícola que invade territórios tradicionais, mercadoriza a natureza, legaliza crimes sociais e ambientais e propaga inúmeras irregularidades fundiárias.

A Amazônia é, atualmente, esse complexo agrícola global particularizado, local onde se propaga a invasão, exploração e financeirização de uma economia das commodities e a manifestação de uma corrida 


\section{Geografia, território e sociedade na Amazônia}

para a competitividade de frações territoriais plurais. Sendo assim, os territórios dos povos e comunidades tradicionais amazônicas, caso da classe social do campesinato, mostram que as policulturas vão perdendo espaço da área plantada para dar lugar a uma produção menos diversificada, como é o caso da produção da commodity soja e milho.

A hegemonia do processo produtivo da economia capitalista do agronegócio é analisada a partir da Produção Agrícola Municipal (PAM). As variáveis e parâmetros, aqui considerados, são para demonstrar como essas culturas vêm sendo produzidas nos estados estudados. O Gráfico 1 mostra a evolução da soja e do milho em toneladas, considerando a somatória de Rondônia, Pará, Amapá e Roraima. O gráfico em questão foi elaborado com base nos dados da PAM (2019), sendo a produção desses grãos nesses estados corresponde ao período de 2010 a 2019. No quadro 1 também é possível verificar a evolução da produção sojeira e do milho por estado.

Gráfico 1 - Soma da produção de soja e milho em Rondônia, Pará, Amapá e Roraima (2010 a 2019).

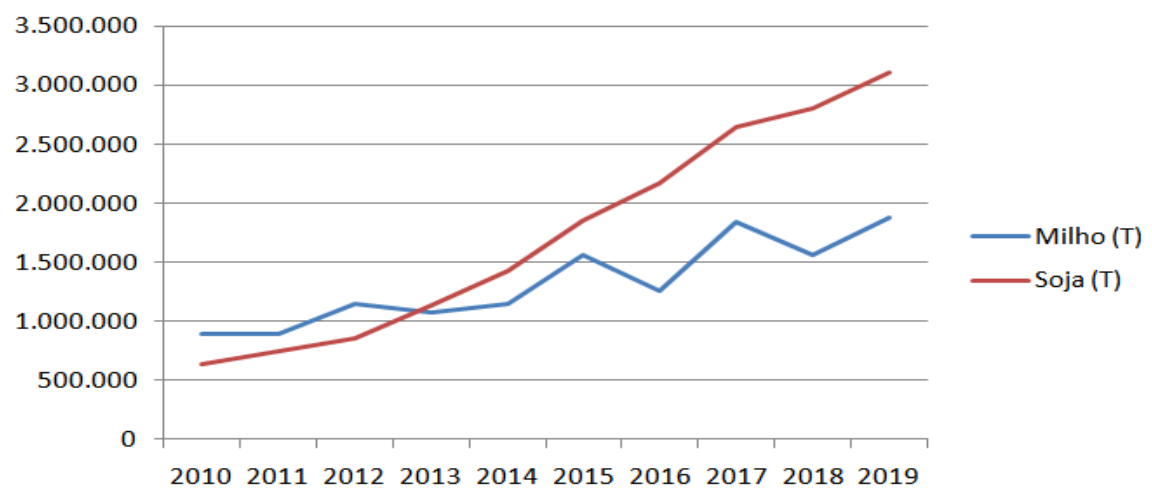

Fonte: Elaborado pelos autores, com base nos dados da PAM, 2019.

Esses dados constatam que, em 2019, os quatro estados somaram 3.107.123 toneladas de produção de soja, o que representa pouco mais de $54 \%$ do total da produção de toda região Norte. Importante ressaltar que a produção dessa cultura cresceu de 2010 para 2019 mais de $390 \%$ nesses estados. A área plantada ou destinada à colheita em 


\section{Agronegócio produz commodities e agricultura camponesa produz alimentos}

hectare também sofreu alteração ao longo da década, como é o caso do Pará, que em 2010 tinha apenas 85.450 hectares de área destinada para plantação de soja e em 2019 esse número saltou para 577.764 hectares, ou seja, um aumento de $576 \%$, o que significa em média $64 \%$ ao ano, para o período analisado. Tal fato coloca o Pará na posição de maior estado de produção de soja, comparado aos demais estados aqui analisados e demais estados que compreende a região Norte.

É possível verificar também pelo gráfico, que nesse recorte temporal e espacial, o milho chegou a superar a soja até 2012, quando esse, por sua vez, começou a obter queda no ano subsequente. Entretanto, embora nos anos seguintes a produção de milho fosse se recuperando, continuou bem abaixo da linha da produção em relação a quantidade, em toneladas de soja. Em um caso específico, mas não único, é possível notar, de acordo com a PAM (2019), que o estado do Amapá em comparação entre esses grãos, curiosamente até 2012, não pontuava produção de soja. Porém, em 2013 essa produção assinalou 12.906 toneladas. A partir daí a quantidade produzida de milho vai diminuindo no Estado, onde em 2019 perfazia $64 \%$ a menos de sua produção em relação a 2010.

Quadro 1 - Produção em toneladas de milho e soja (2010 a 2019).

\begin{tabular}{|l|r|r|r|r|r|r|r|r|r|r|}
\hline \multirow{2}{*}{ ANO } & \multicolumn{5}{|c|}{ Milho (em grão) } & \multicolumn{4}{c|}{ Soja (em grão) } \\
\cline { 2 - 12 } & Rondônia & Roraima & \multicolumn{1}{|c|}{ Pará } & \multicolumn{1}{|c|}{ Amapá } & \multicolumn{1}{c|}{ Total } & Rondônia & Roraima & Pará & \multicolumn{1}{c|}{ Amapá } & Total \\
\hline 2010 & 365.980 & 12.800 & 519.258 & 3.233 & 901.271 & 385.388 & 3.920 & 243.616 & 0 & 632.924 \\
\hline 2011 & 340.045 & 11.800 & 541.128 & 2.466 & 895.439 & 419.522 & 10.080 & 317.093 & 0 & 746.695 \\
\hline 2012 & 534.423 & 11.800 & 604.799 & 2.120 & 1.153 .142 & 470.485 & 14.000 & 373.398 & 0 & 857.883 \\
\hline 2013 & 449.449 & 15.438 & 613.546 & 2.011 & 1.080 .444 & 574.900 & 40.200 & 506.347 & 12.906 & 1.134 .353 \\
\hline 2014 & 542.279 & 15.350 & 590.078 & 1.958 & 1.149 .665 & 614.678 & 33.950 & 736.947 & 40.792 & 1.426 .367 \\
\hline 2015 & 787.093 & 15.528 & 759.662 & 1.650 & 1.563 .933 & 718.429 & 55.795 & 1.022 .677 & 29.370 & 1.856 .271 \\
\hline 2016 & 602.411 & 17.013 & 643.008 & 1.517 & 1.263 .949 & 759.928 & 67.347 & 1.304 .598 & 42.351 & 2.174 .224 \\
\hline 2017 & 933.956 & 41.374 & 872.065 & 1.564 & 1.848 .959 & 913.454 & 45.077 & 1.632 .115 & 54.400 & 2.645 .046 \\
\hline 2018 & 735.150 & 44.648 & 790.965 & 1.155 & 1.571 .918 & 1.000 .311 & 105.780 & 1.638 .469 & 57.239 & 2.801 .799 \\
\hline 2019 & 1.004 .717 & 50.390 & 827.720 & 1.138 & 1.883 .965 & 1.190 .195 & 88.394 & 1.781 .672 & 46.862 & 3.107 .123 \\
\hline
\end{tabular}

Fonte: Organizado pelos autores, 2021, com base nos dados da PAM, 2019.

Contraditoriamente a essa produção voraz de monoculturas executada pelo agronegócio, encontram-se as famílias produtoras de alimentos diversificados, o campesinato, que buscam estratégias de fortalecimento e a praticidade de uma produção saudável. Segundo Elias 
(2011) a substituição de alimentos por commodities é decorrente da especialização produtiva.

Para a autora, tal fato implica não somente na diminuição da diversidade de alimentos produzidos no campo, como também na expulsão dos povos tradicionais, o que acarretará o inchaço das cidades e na fragmentação, desarticulação e enfraquecimento das lutas sociais frente ao agronegócio. Nesse contexto, "as próprias contradições do desenvolvimento do capitalismo estão soldando a união contraditória que separou no início da sua expansão: a indústria e a agricultura, a cidade e o campo" (Elias, 2011, p. 160).

Para tanto, aqui é preciso abrir um parêntese para refinar o propósito deste estudo. Com base nos dados do Censo Agropecuário de 2017, nas lavouras temporárias é possível verificar a produção familiar e não familiar e constatar que o potencial de produção não familiar se encontra nas culturas de soja e milho e com percentual expressivo, igualmente na cana de açúcar (Vide quadro 2). Pelo contrário, as agriculturas camponesas e familiares são regradas de uma variedade produtiva. Destarte, "essa diversificação pode incluir a produção de diferentes tipos de culturas, como lavouras, pecuária, silvicultura, piscicultura, e, também, de diversas variedades genéticas em uma mesma cultura" (Sambuichi et al, 2014, p. 63). 
Agronegócio produz commodities e agricultura camponesa produz alimentos

Quadro 2 - Produção da lavoura temporária: agricultura de base familiar x agricultura não familiar (2017).

\begin{tabular}{|l|c|c|}
\hline \multicolumn{1}{|c|}{ Produtos da lavoura temporária } & $\begin{array}{c}\text { Agricultura } \\
\text { Familiar (RO, } \\
\text { RR, PA, AP) }\end{array}$ & $\begin{array}{c}\text { Agricultura não } \\
\text { familiar (RO, } \\
\text { RR, PA, AP) }\end{array}$ \\
\hline Abacaxi (Mil frutos) & 93.501 & 1.334 \\
\hline Abóbora, moranga, Jerlmum (Toneladas) & 10.202 & 3.178 \\
\hline Amendoim em casca (Toneladas) & 424 & 36 \\
\hline Arroz em casca (Toneladas) & 28.305 & 198.403 \\
\hline Batata-inglesa (Toneladas) & 1.190 & 27 \\
\hline Cana-de-açúcar (Toneladas) & 15.966 & 984.472 \\
\hline Cebola (Toneladas) & 12 & 1 \\
\hline Fava em grão (Toneladas) & 169 & 25 \\
\hline Feijão preto em grão (Toneladas) & 389 & 35 \\
\hline Feijão de cor em grão (Toneladas) & 3.826 & 2.368 \\
\hline Feijão fradinho em grão (Toneladas) & 5.426 & 5.809 \\
\hline Feijão verde (Toneladas) & 1.974 & 508 \\
\hline Gergelim (semente) (Toneladas) & 6 & 150 \\
\hline Mandioca (aipim, macaxeira) (Toneladas) & 1.047 .450 & 104.174 \\
\hline Melancia (Toneladas) & 37.082 & 10.900 \\
Melão (Toneladas) & 227 & 735 \\
\hline Milho em grão (Toneladas) & 110.191 & 1.108 .678 \\
\hline Soja em grão (Toneladas) & 61.514 & 1.974 .365 \\
\hline Sorgo em grão (Toneladas) & 364 & 10.105 \\
\hline Tomate rasteiro (industrial) (Toneladas) & 845 & 70 \\
\hline Forrageiras para corte (Toneladas) & 1.732 & 7.143 \\
\hline Cana forrageira (Toneladas) & 4.299 & 973 \\
\hline Milho forrageiro (Toneladas) & 14.437 & 204.815 \\
\hline Outros produtos (Toneladas) & 2.821 & 13.654 \\
\hline
\end{tabular}

Fonte: Organizado pelos autores, 2021, com base no Censo agropecuário de 2017.

O quadro 2 ilustra a soma dos principais produtos das lavouras temporárias produzidas, de acordo com o censo agropecuário de 2017, nos estados em estudo. A tabulação dos dados compreende a divisão de produção entre aquelas culturas que são produzidas pelos agricultores, que desempenham atividades familiares e aqueles não familiares.

Percebe-se que nos dados comparativos analisados, enquanto a agricultura não familiar, materializada no agronegócio, tem um grande índice de produção de soja (1.974.365 t) e de milho (1.108.678 t), a agricultura de ordem familiar, entendida como agricultura camponesa, 


\section{Geografia, território e sociedade na Amazônia}

apresenta as maiores produções de alimentos, a exemplo do(a) abacaxi, mandioca, jerimum, tomate etc.

Em se tratando de lavoura permanente, na comparação também é possível verificar que a agricultura de base familiar detém a maior parte da quantidade produzida das principais culturas alimentares, com exceção do açaí e do coco-da-baía, como pode ser verificado no Gráfico 2 e no quadro 3.

Gráfico 2 - Produção da lavoura permanente: agricultura de produção familiar x agricultura de produção não familiar (2017).

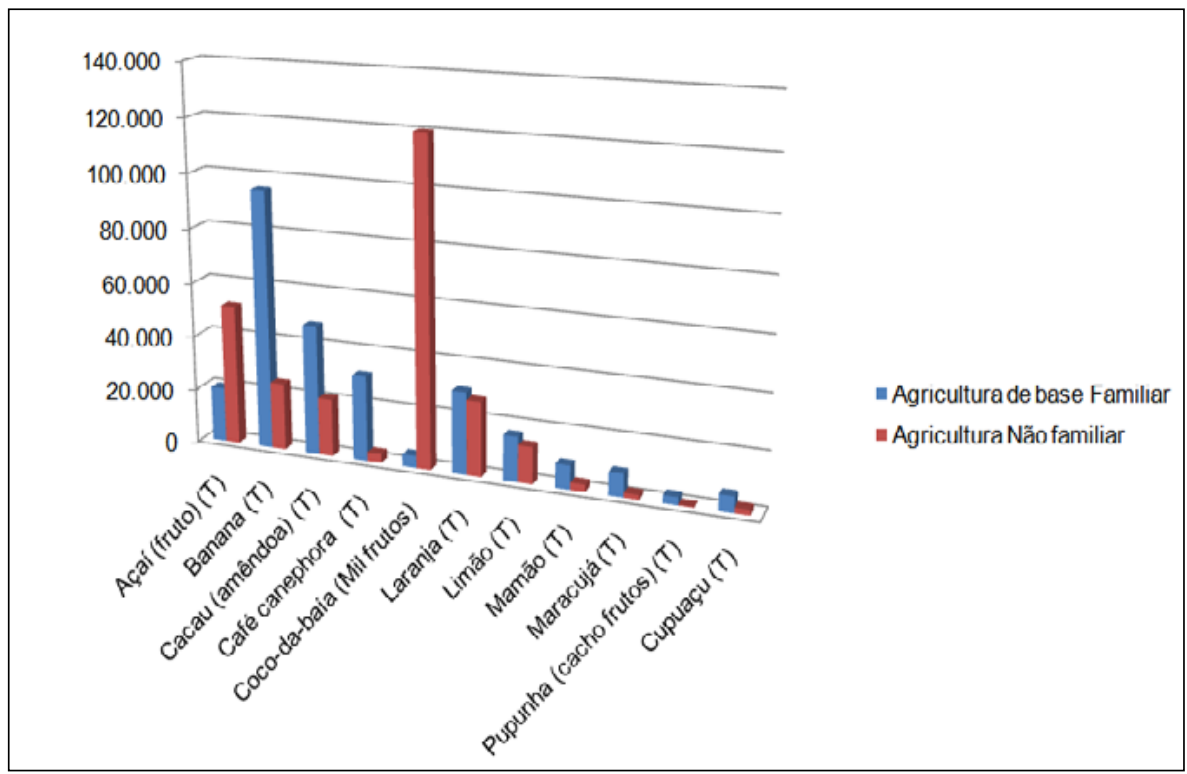

Fonte: Organizado pelos autores, 2021, com base no Censo agropecuário de 2017.

Nesse sentido, verifica-se que a produção diversificada de produtos alimentares se destaca majoritariamente na agricultura de base familiar, em que corrobora para os pilares da soberania alimentar. Este conceito muito defendido pelo Movimento dos Pequenos Agricultores (MPA) orienta e reforça a luta camponesa pelo direito de produzir de forma sustentável e garantir uma alimentação de qualidade. Para Altafin (2005), a família camponesa não visa a lucratividade (acumulação), mas um de seus objetivos é proporcionar o bem-estar das unidades familiares e promover a recriação social. 


\section{Agronegócio produz commodities e agricultura camponesa produz alimentos}

Quadro 3 - Produção da lavoura permanente: agricultura de base familiar $\mathrm{x}$ agricultura não familiar (2017).

\begin{tabular}{|l|c|c|}
\hline Produtos da lavoura permanente & $\begin{array}{c}\text { Agricultura de base } \\
\text { Familiar (RO, RR, } \\
\text { PA, AP) }\end{array}$ & $\begin{array}{c}\text { Agricultura não } \\
\text { familiar (RO, RR, } \\
\text { PA, AP) }\end{array}$ \\
\hline Açaí (fruto) $(\mathrm{T})$ & 20.184 & 51.571 \\
\hline Banana (T) & 95.440 & 24.658 \\
\hline Cacau (amêndoa) (T) & 47.711 & 21.167 \\
\hline Café canephora (T) & 31.403 & 3.318 \\
\hline Coco-da-baía (Mil frutos) & 4.446 & 120.137 \\
\hline Laranja (T) & 30.315 & 27.562 \\
\hline Limão (T) & 16.593 & 13.625 \\
\hline Mamão (T) & 8.819 & 2.620 \\
\hline Maracujá (T) & 8.579 & 1.695 \\
\hline Pupunha (cacho frutos) (T) & 2.916 & 353 \\
\hline Cupuaçu (T) & 6.027 & 2.079 \\
\hline
\end{tabular}

Fonte: Organizado pelos autores, 2021, com base no Censo agropecuário de 2017.

É preciso ressaltar o quanto as políticas públicas para a agricultura camponesa são deficitárias e se encontram deterioradas, enquanto as políticas dirigidas para o setor do agronegócio ganham maiores investimentos e incentivos governamentais, tornando-se ponto de pauta para o Ministério da Agricultura que é comandado pela bancada ruralista, materializado no agronegócio latifundiário. Assim, Fernandes (2014) compreende que as políticas públicas estão para atender os interesses do agronegócio e não para os interesses do campesinato, configurando como disputas paradigmáticas que são cristalizadas contraditoriamente no espaço agrário brasileiro.

Embora a institucionalização do Programa Nacional de Fortalecimento da Agricultura Familiar (Pronaf) em 1996, e sua ampliação a partir de 2004, seja um marco e uma conquista reivindicatória dos movimentos sociais para acesso às políticas públicas, o acesso a tais políticas públicas é um processo burocrático, limitado, incoerente e desigual. Pitaguari e Lima (2005) pontuam que essas políticas deveriam contribuir de forma mais expressivas no fortalecimento da agricultura de base familiar para diminuir, sobretudo, as dificuldades históricas, além de erradicar as burocráticas formas de acesso ao crédito. Portanto, ao analisar o Censo Agropecuário de 2017, reforça-se o quanto a agricultura camponesa de base familiar precisa da formulação e efetivação de políticas públicas, uma vez que estas são construídas e implementadas para atender aos interesses geoestratégicos do agronegócio. 


\section{Geografia, território e sociedade na Amazônia}

\section{CONSIDERAÇÕES FINAIS}

A análise comparativa das formas de produção que envolve agronegócio e campesinato realizada nesse artigo, a partir do contexto da Amazônia, confirma a ideia de que o agronegócio produz commodities e a agricultura camponesa produz alimentos. Apesar das narrativas presentes no pensamento agro-hegemônico negacionista quererem demostrar que o agronegócio latifundiário é exclusivo e favorável para a economia do país e o mais "produtivo", reforçado na propaganda intencional de que o Agro é Pop, o Agro é Tech e o Agro é Tudo, é na agricultura camponesa que está o cerne de uma economia altamente produtiva e geradora de alimentos.

A agricultura capitalista produz e comercializa mercadorias globalizadas que não têm a pretensão de alimentar a população, mas atender os interesses dos agentes hegemônicos (empresas multi/transnacionais e o Estado). Ao contrário do agronegócio, a agricultura camponesa, que por possuir uma poliprodução (agroextrativista e agroecológica) e autonomia de como, quando, que e como produzir alimentos sadios que são consumidos pela própria família; sua produção de alimentos saudáveis e diversificados é destinada a abastecer o consumo daqueles que habitam o campo e, principalmente, as cidades.

Presumidamente, as relações processuais e as escalas geográficas entre essas duas formas de produção são de caráter antagônico, materializando conflitos de luta pela terra e território de diversas ordens. Os crescentes investimentos, destinados à expansão e ao favorecimento da agricultura capitalista, significam o negacionismo da agricultura camponesa e implica na expropriação e na redução dos territórios de vida e trabalho da classe social do campesinato amazônico.

Com base nas análises de dados secundários e as discussões teórico-conceituais, identificou-se que, enquanto a produção não familiar verticalizada de commodities (monocultura) instaura um corporativismo do território pelo capital globalizado, cuja pretensão é a acumulação ampliada do capital, a produção familiar camponesa demonstra que as práticas espaciais e territoriais se preocupam com a variedade produtiva de verduras, frutas, legumes, hortaliças, dentre outros produtos cultivados e extrativos (origem vegetal e animal).

Por conseguinte, o modelo do agronegócio é o que maior recebe investimentos de políticas públicas, para ampliar produção de mercadorias agroexportadoras globalizadas e a territorialização de grandes tra- 


\section{Agronegócio produz commodities e agricultura camponesa produz alimentos}

dings trans escalares, a exemplo das redes logísticas e portos privados, que são redimensionadas para a Amazônia através do projeto Arco Norte. Contudo, o modelo do campesinato que produz alimentos saudáveis e que luta por direitos humanos e territoriais para produzir, consumir e reproduzir na perspectiva da soberania alimentar, é obrigado a enfrentar e se defender das pressões e coações impostas pelo agronegócio.

Certamente, não é forçoso e muito menos inequívoco, abordar de que a Amazônia é uma região de expansão de fronteira agrícola e da efetivação de novos sistemas de objetos que são estranhos e conflituosos aos lugares, como é o caso da construção de "redes de integração", rodoviária, hidroviária, hidroportuária e ferroviária. Os dados aqui levantados dos estados Rondônia, Pará, Amapá e Roraima comprovam que a eficácia de adaptação das produções de monoculturas oriunda da produção não familiar, que invadiu os diferentes territórios e territorialidades dos povos amazônicos, vem fortalecendo a produção espacial de grãos e contribuindo para a redução de outras culturas agrícolas. É o caso da produção familiar camponesa, que sob um discurso do modo de produção capitalista, é considerada como "menos produtiva", mas os dados e a realidade do contexto socioespacial demonstram exatamente o oposto.

\section{REFERÊNCIAS}

ALTAFIN, I. Reflexões sobre o conceito de agricultura familiar. Brasília, 2005, p. 18 Disponível em: www.enfoc.org.br/system/arquivos/ documentos/70/f1282reflexoes-sobre-o-conceito-de-agricultura-familiar ---iara-altafin---2007.pdf. Acesso em: 25 jan. 2021.

CONCEIÇÃO, F. S. Da territorialização do capital e a expansão do agronegócio sojeiro: lutas e (re)existências dos camponeses/camponesas das comunidades Nova Esperança e Nova Aliança no município de Belterra/Pará. Dissertação (Mestrado em Geografia) - Fundação universidade federal de Rondônia - UNIR. Porto Velho, Rondônia, 2017, 225 f.

CONCEIÇÃO, F. S da.; RIBEIRO, A. F. A. COSTA SILVA, R. G. (Des) encontros entre a estrada e o rio: o caso da Gleba da Bota no oeste da Amazônia paraense. Revista GeoNordeste, São Cristóvão, Ano XXX, n. 1, p. 6-25, Jan./Jun. 2019.

CONCEIÇÃO, F. S da. COSTA SILVA, R. G. Entre rio Tapajós e rodovia BR-163 existem territórios em disputas em Belterra-Pará, Amazônia brasileira. In: BARROS, M. J. B. (Org.). Políticas públicas e dinâmicas territoriais no oeste do Pará. Ananindeua: Itacaiúnas, 2020, p. 259. 
COSTA, F. de A. Economia camponesa nas fronteiras do capitalismo: teoria e prática nos EUA e na Amazônia Brasileira. Belém: NAEA, 2012, p. 210.

COSTA SILVA, R. G. da. Globalização, agricultura e a formação do meio técnico-científico-informacional em Rondônia. Acta geográfica (UFRR), p. 69-83, 2013.

COSTA SILVA, R. G. A regionalização do agronegócio da soja em Rondônia. GEOUSP. Espaço e tempo (Online), São Paulo, v. 18, n. 2, p. 298-312, 2014. Disponível em: www.revistas.usp.br/geousp/article/ view/84534. Acesso em: 23 jan. 2021.

COSTA SILVA, R. G. da.; LIMA, L. A. P. A espiral da desgraça: notas para um debate sobre mineração em áreas indígenas, direitos humanos e território dos povos amazônicos. In: Grupo de Trabalho do CLACSO (Orgs.). Dossier: Saberes territoriales indígenas y sus espacialidades. Boletín Geocrítica Latino-americana. n. 4, abril, 2020, p. 105-114.

ELIAS, D. Agronegócio e novas regionalizações no Brasil. Revista brasileira de estudos urbanos e regionais (Anpur), v. 13, p. 153-170, 2011.

FERNANDES, B. M. Disputa paradigmática: questão agrária versus capitalismo agrário; Stakeholders: uma luta longa e constante; Disputa política: agronegócio e campesinato. In: FERNANDES, B. M.; WELCH, C. A.; GONÇALVES, E. C. Os usos da terra no Brasil: debates sobre políticas fundiárias. São Paulo: Cultura Acadêmica: Unesco, 2014. p. 47-64.

GUHUR, D. M. P.; TONÁ. N. Agroecologia. In: CALDART, R. S.; PEREIRA, I. B., ALENTEJANO, P.; FRIGOTTO, G. (Orgs.). Dicionário da educação do campo. Rio de Janeiro, São Paulo: Escola Politécnica de Saúde Joaquim Venâncio, Expressão Popular, 2012, p.788.

INSTITUTO BRASILEIRO DE GEOGRAFIA E ESTATÍSTICA (IBGE). Censo agropecuário brasileiro de 2017. Rio de Janeiro: IBGE (2021). Disponível em: www.censoagro2017.ibge.gov.br/. Acesso entre $10 \mathrm{dez}$. 2020 e 7 fev. 2021.

INSTITUTO BRASILEIRO DE GEOGRAFIA E ESTATÍSTICA (IBGE). Produção municipal agrícola (PAM), 2019. Rio de Janeiro: IBGE (2021). Disponível em: www.sidra.ibge.gov.br/pesquisa/pam/tabelas. Acesso entre 10 dez. 2020 e 7 fev. 2021.

HAESBAERT, Rogério. Dos múltiplos territórios à multiterritorialidade. In: Seminário Internacional sobre Múltiplas Territorialidades. Document de travailà partir d'une versionrévisée d'une communication pré- 


\section{Agronegócio produz commodities e agricultura camponesa produz alimentos}

sentéeau $1^{\circ}$ Seminário Nacional sobre múltiplas territorialidades. Porto Alegre: UFRGS, 23 set. 2004.

MARTINS, José. S. Fronteira: a degradação do outro nos confins do humano. 2. ed., 2. reimpr. São Paulo: Contexto, 2014.

MICHALSKI, A.; COSTA SILVA, R. G. da. A caminho do Norte: cartografia dos impactos territoriais do agronegócio em Rondônia (Amazônia ocidental). Confins [En ligne], 45 | 2020. Disponível em: www.journals. openedition.org/confins/28017.

PITAGUARI, Sinival. O.; LIMA, J. Ferrera de. As idéias keynesianas e o crescimento do produto nas economias locais. Interações: Revista internacional de desenvolvimento local, Campo Grande, v. 6, n. 10, p. 11-20, 2005. Disponível em: www.multitemas.ucdb.br/interacoes/ article/download $/ 511 / 553+\& c d=1 \&$ hl=pt-PT\&ct=clnk\&gl=br. Acesso em: 26 jan 2021.

RODRIGUES, J. C. O. Arco Norte e as políticas públicas portuárias para o Oeste do estado do Pará (Itaituba e Rurópolis): apresentação, debate e articulações. Rev. NERA Presidente Prudente ano 21, n. 42, p. 202-228 Dossiê (2018).

SAMBUICHI, R. HELENA, R. et al. Diversificação produtiva como forma de viabilizar o desenvolvimento sustentável da agricultura familiar no Brasil. In: Monastério, L.; NERI, M. C.; SOARES, S. S. D. (org). Brasil em desenvolvimento 2014: estado, planejamento e políticas públicas. Brasília: IPEA, 2014. p. 61-84.

SANTOS, M. Por uma outra globalização: do pensamento único à consciência universal. 3. ed. Rio de Janeiro/São Paulo: Record, 2000.

SANTOS, M. [1996]. A natureza do espaço: técnica e tempo. Razão e emoção. EDUSP. São Paulo, 2012.

STAEVIE, P. M. Um balanço das discussões sobre os impactos do agronegócio sobre a Amazônia brasileira. Rev. NERA, Presidente Prudente ano 21, n. 42, p. 98-112. Disponível em: www.revista.fct.unesp.br/index.php/nera/article/view/5684. Acesso em: 25 jan. 2021.

TRINDADE JÚNIOR, S.C. C. da. Cidades na floresta: os "grandes objetos" como expressões do meio técnico-científico informacional no espaço amazônico. Revista IEB, n. 50, 2010 set./mar. p. 13-138. 


\section{O CIRCUITO ESPACIAL DE PRODUÇÃO COMO}

\section{INSTRUMENTO DE ANÁLISE DE DESENVOLVIMENTO REGIONAL: CASO DA FARINHA DE MANDIOCA ${ }^{1}$}

Eubia Andréa Rodrigues*

\section{INTRODUÇÃO}

O que se pretende discutir são as consequências em função da entrada do capital monopolista, no interior da Amazônia brasileira, precisamente no espaço rural a partir do circuito espacial da farinha de mandioca que, de acordo com Josué de Castro (1984), é um complemento da base alimentar do homem amazônico. Portanto, o seu consumo proporciona uma demanda produtiva que vai desde o pequeno camponês ao empresário, no Médio Solimões.

Desta forma, o estudo do circuito espacial de produção da farinha de mandioca descreve as etapas do processo de produção, circulação, distribuição e consumo, voltados para uma formação econômica espacial, analisando a sociedade e a natureza, além de analisar a disposição da força de trabalho impressa no circuito para o entendimento do modo de vida como um demarcador territorial com diferentes dinâmicas espaciais, estando esta força relacionada ao agricultor familiar. Portanto, um dos objetivos da pesquisa foi identificar o sujeito produtor da farinha de mandioca e seu comportamento frente as relações capitalistas de produção. Desta forma foi necessário fazer uma investigação em áreas distintas da Amazônia para identificar contradições e semelhanças no circuito espacial da produção de farinha de mandioca.

\footnotetext{
${ }^{1}$ Texto referente ao projeto de doutorado em desenvolvimento no Programa de Pós-graduação em Geografia - PPGG/UNIR, sob a orientação do professor Ricardo Gilson da Costa Silva.
} 


\section{$\square$ circuito espacial de produção como instrumento de análise de desenvolvimento regional: caso da farinha de mandioca}

Para esta análise comparativa, definiu-se a produção de farinha de Cruzeiro do Sul (AC) e a produção de Santarém (PA), considerando estas duas áreas as maiores produções da região. Como conclusão, por meio do circuito espacial de produção a abordagem multidisciplinar se apresentou como adequada, permitiu a integração de diversas áreas do conhecimento que se entrecruzaram na lógica de fundamentar a valoração e valorização da produção, tendo o modo de vida como elemento balizador do desenvolvimento regional. "Dessa forma, são as relações sociais de produção e o processo contínuo e contraditório de desenvolvimento das forças produtivas que dão configuração histórica e específica ao território" (Oliveira, 2007, p. 74).

O presente artigo faz uma abordagem sobre o desenvolvimento regional a partir do circuito espacial de produção da farinha de mandioca, com base em uma análise comparativa entre áreas produtoras que alcançaram um mercado mais amplo se comparado com o mercado do médio Solimões. Para a teorização deste artigo, buscou-se uma discussão sobre os conceitos de desenvolvimento regional, agricultura familiar, políticas públicas e circuito espacial de produção. Conceitos de fundamental importância para entender como planejar a economia de uma microrregião como o médio Solimões e que norteiam o discurso.

Para o desenvolvimento da pesquisa foi necessário recorrer as bases bibliográficas para uma descrição sucinta dos conceitos utilizados, como pontos importantes para entender por que que a produção de farinha de mandioca, no médio Solimões, não alcança uma projeção em uma escala maior, comparada as áreas da análise comparativa. Outra base de fundamental importância foi a do Instituto Brasileiro de Geografia e Estatística (IBGE), que permitiu a organização de tabelas comparativas a partir dos dados encontrados. O trabalho de campo nas pequenas propriedades e no comércio da cidade de Tefé viabilizou identificar os anseios e as angústias dos agricultores familiares, no circuito espacial de produção da farinha de mandioca. Esses três momentos desenham o percurso metodológico da pesquisa, sendo essa de caráter quali-quantitativo, com uma característica empírica, permitindo, uma aproximação entre sujeito e objeto.

Este artigo se estrutura em três principais pontos. Primeiro, é o discurso teórico sobre as categorias e conceitos definidos para fundamentar a pesquisa e dar um caráter científico para a atividade. $\mathrm{O}$ segundo ponto refere-se a uma pequena descrição geográfica das áreas escolhidas 


\section{Geografia, território e sociedade na Amazônia}

para a realização da análise comparativa (Tefé, Santarém, e Cruzeiro do Sul). E por último os resultados com as conclusões.

\section{Desenvolvimento Regional}

Sabe-se que o desenvolvimento regional é um conceito muito complexo de se discutir, principalmente ao nível de Brasil. Os estudos regionais aparecem em meados do século XX com maior intensidade em decorrência de propor um planejamento para a economia nacional, um planejamento que viabilizasse o desenvolvimento regional/nacional.

Neste sentido, é necessário um discurso sobre regionalização do território, sendo esse um conceito que deriva de região. $\mathrm{Na}$ perspectiva de região, pode-se pensar como uma categoria da ciência geográfica, que no Brasil se pautou na escola francesa em que é inquestionável a concepção regional.

A intenção desta proposta não é se aprofundar no discurso sobre a categoria região, mas compreender essa categoria dentro da perspectiva de desenvolvimento regional. Como salienta Monteiro Neto (2005, p. 22), em se tratando de Brasil, "a questão regional brasileira tem sido amplamente analisada à luz de diferentes contextos socioeconômicos e institucionais nas últimas décadas, bem como sob a influência de diferentes arcabouços metodológicos". Portanto, não tem como desvincular o desenvolvimento regional do fator econômico, que na maioria das vezes, subentende-se o desenvolvimento como sinônimo de crescimento.

No Brasil, esse tema vem sendo discutido desde a década de 1950, momento em que o país vem engatinhando no processo de industrialização na região Sudeste, centro econômico e político do país, vinculado a uma "economia de arquipélago", descrita por Caio Prado Junior. Nesse período o Brasil vai se direcionando de uma economia agroexportadora para uma economia de importação industrial. Desta forma, é necessário entender o contexto regional em que o Brasil se encontrava. Porque não se pode definir uma região somente a partir de seu caráter político, é conveniente entender essa categoria como um conceito construído em função de significados e natureza. Há toda uma articulação de fatores que promovem o conceito regional.

A presente proposta apresenta o discurso de região pautada em uma abordagem da "modernidade radicalizada" (Giddens, 1991), onde o Estado não tem decisão determinante na configuração espacial com bases 


\section{$\square$ circuito espacial de produção como instrumento de análise de desenvolvimento regional: caso da farinha de mandioca}

em critérios padronizados, a categoria se fortalece a partir da articulação e complexidade de um espaço (local, regional, global) mais coeso, como afirma Lecione (1999, p. 127) "a partir de uma construção mental do pesquisador, sendo uma construção intelectual”. Deve-se pensar região como um espaço coeso e funcional que, segundo Milton Santos (1999), identificado "pelos fluxos econômicos, que mesmo podendo desenvolver relações diretamente de nível local ao global, ainda tem laços com contextos regionais ou de mesoescala".

A categoria região caracteriza a estrutura organizacional do espaço da área em estudo, uma vez que vai se transformando em decorrência da utilização do solo e das relações de produção existentes. Isso explica as diferentes áreas que compõem o espaço brasileiro. Portanto, deve-se pensar a regionalização brasileira a partir de suas particularidades ambientais, sociais, culturais e econômicas. Nesta análise, viabiliza-se o que se pode descrever como desenvolvimento regional.

O desenvolvimento regional brasileiro vem sendo moldado desde a década de 1950 quando foram criadas políticas públicas que apresentavam uma visão de desenvolvimento regional, com base em planos e programas. A exemplo da Sedene/Sudam/Sudeco, que posteriormente foram se desmontando a partir de uma nova política através do PNDR (2000), que também apresentou falhas em sua execução.

Como pensar o desenvolvimento regional para a Amazônia, sendo essa região caracterizada como multifacetada, segundo Porto Gonçalves em Amazônia, Amazônias? É necessário um estudo particularizado que mostra uma análise diferenciada em todas as dimensões, em lugares diversos que requerem uma compreensão comportamental dos diferentes sujeitos. Um estudo em uma microescala permite entender que a aplicabilidade de um plano de desenvolvimento regional requer uma orientação metodológica mais específica. Veja como exemplo a Amazônia, que dentro de um contexto regional aparece como uma região com características humanas e naturais comuns, em toda sua dimensão, mas quando se analisa suas particularidades, percebe-se as várias Amazônias (do agronegócio, da agricultura familiar, da várzea, da terra firma, do caboclo ribeirinho, do indígena, etc.). Como elaborar um plano de desenvolvimento regional sem analisar as especificidades da Amazônia?

Pensar em desenvolvimento regional para o Brasil é entender o espaço brasileiro em suas diferentes nuances, para não se cometer os mesmos erros do passado. Dentro destas particularidades espaciais, pode-se 


\section{Geografia, território e sociedade na Amazônia}

pensar na atuação dos diferentes sujeitos que (re)produzem o espaço. No contexto amazônico, está o produtor de farinha de mandioca que aqui será identificado como agricultor familiar. Este sujeito desenha a economia brasileira debruçada no que se denomina de agricultura familiar.

\section{Agricultura familiar e POlíticas públicas}

Tem-se as diferentes formas conceituais sobre o agricultor familiar, essas diferentes formas têm um contexto histórico, econômico e geográfico onde há a necessidade de um intenso discurso sobre a categoria, que não é objetivo deste trabalho, mas é necessário identificar este sujeito no circuito espacial de produção de farinha de mandioca, para analisar seu modo de vida e como este se relaciona ao desenvolvimento regional, uma vez que este caracteriza a economia agrária da região.

Alguns teóricos nos proporcionam um entendimento sobre o conceito de agricultura familiar e se dividem quanto à aplicação da prática capitalista nesta classe. Há os que defendem que essa classe desaparecerá com a intensificação das práticas capitalistas no campo, como Kautsky (1972), Lênin (1985) que defendem o fim do campesinato. Mas existem aqueles que defendem a permanência, acreditando em uma transformação na base de produção, como Chayanov (1974) e Ploeg (2006). Porém, existem autores brasileiros que defendem a permanência da agricultura familiar, como Wanderley (1995), Schneider (1999) José de Souza Martins, Ariovaldo Umbelino de Oliveira (2001) que acreditam em uma equidade social e econômica.

Nesta proposta, o conceito está ligado diretamente, à Política Nacional de Agricultura Familiar, institucionalizada como um modelo de geração de desenvolvimento rural.

A Política Nacional de Agricultura Familiar foi instituída por meio da Lei de $\mathrm{n}^{\circ}$ 11.326/2006 que estabelece um conjunto de diretrizes, conceitos, princípios e instrumentos que possibilitaram uma definição mais clara de quem são e quais são os requisitos a serem considerados para determinar os beneficiários das políticas públicas destinadas à agricultura familiar (Curso 4 Políticas Públicas e Agricultura Familiar. 2018, p. 15).

A instituição desta lei foi de suma importância para a inclusão do agricultor familiar nas políticas públicas brasileiras, onde busca acesso à 


\section{$\square$ circuito espacial de produção como instrumento de análise de desenvolvimento regional: caso da farinha de mandioca}

diversos programas que fomentam a produção familiar, dentro de qualquer segmento do circuito espacial de produção.

Esta política foi regulamentada, propiciando uma definição ainda mais objetiva sobre os beneficiários das políticas públicas direcionadas à agricultura familiar, por meio do estabelecimento de parâmetros quantificáveis sobre os requisitos de enquadramento das disposições sobre a Unidade Familiar de Produção Agrária (UFPA) e da instituição do Cadastro Nacional de Agricultura Familiar (CAF).

O discurso sobre agricultura familiar aqui será pautado na Política Nacional de Agricultura Familiar instituído pelo Decreto 9.064/2017, em que a agricultura familiar está vinculada a Unidade Familiar de Produção Agrária (UFPA), proporcionando a compreensão dos parâmetros que dão acesso as políticas públicas para a agricultura familiar.

Portanto, a Unidade Familiar de Produção Agrária é:

O conjunto de indivíduos composto por uma família que explora uma combinação de fatores de produção com a finalidade de atender sua subsistência, bem como a demanda da sociedade por alimentos e outros bens e serviços, e que resida no próprio estabelecimento, que desenvolve as atividades ou em local próximo a ele (Brasil, 2017, art. $2^{\circ}$, inciso I).

Dentro da Política Nacional de Agricultura Familiar é importante destacar que as configurações de organização da agricultura familiar não envolvem somente o agricultor como pessoa física, mas também envolve o formato de pessoa jurídica. Desta forma, um conjunto de unidades familiares podem formar uma associação e fortalecer o grupo frente às amarras capitalistas. Percebe-se que esta classe é amparada por um conjunto de medidas que, quando bem usadas, promovem a permanência do agricultor familiar no mercado, seja em grande escala como em microescala. Direcionando todo um mecanismo de acesso a um capital disponibilizado pelo Governo Federal. Não se pode pensar que a acessibilidade é fácil, ou seja, o agricultor familiar necessita se inserir num conjunto de exigências, que na maioria das vezes promove um recuo por causa das questões burocráticas estabelecidas.

A Política Nacional da Agricultura Familiar tem incentivado o desenvolvimento desta classe por meio de créditos e ações que promovam uma maior produção e direção a um mercado mais amplo e diverso, além da busca pela sustentabilidade. Mas o que se percebe é uma buro- 


\section{Geografia, território e sociedade na Amazônia}

cratização e a falta da organização da classe tem promovido um descaso por parte do agricultor familiar, o que caracteriza a região do médio Solimões, com destaque no circuito espacial de produção da farinha de mandioca. O circuito espacial de produção, quando analisado, permite entender todo o processo de produção para se verificar onde se encontram os acertos e os erros. Desta forma, é necessário recorrer a abordagem miltoniana, sendo mais geográfico, para não confundir com o conceito de cadeia produtiva, que tem uma conotação voltada para a ciência geográfica.

\section{Circuito espacial de PROduÇão}

Segundo Santos (1997, p. 17), circuitos espaciais de produção seriam as várias etapas pelas quais se passaria um produto, dizendo o autor que ocorre desde o início do processo de produção até o consumo final. Tomando como exemplo a produção da farinha de mandioca, inicia-se com a prática da queimada em uma determinada área, de capoeira ou não, depois a limpeza para a plantação da maniva, passando pela colheita dos tubérculos de mandioca, sendo direcionados para o igarapé ou piscinas para o amolecimento, depois pela torrefação, até chegar ao consumidor através das feiras agrícolas e supermercados.

Teríamos que observar, então, vários itens distintos, assim, sobre a matéria-prima - local de origem, formas de seu transporte, tipo de veículo transportador etc.; sobre a mão-de-obra - qualificação, origem, variação das necessidades nos diferentes momentos da produção etc.; sobre estocagem - quantidade e qualidade dos armazéns, dos silos, proximidade da indústria, relação entre estocagem e produção etc.; sobre transportes qualidade, quantidade e diversidade das vias de transportes, dos meios de transporte etc.; sobra a comercialização - existência ou não de monopólio de compra, formas de pagamento, taxação de impostos etc.; sobre o consumo - quem consome, onde, tipo de consumo, se produtivo ou consumitivo etc. (Santos, 1997, p. 18).

Para iniciarmos uma discussão sobre circuitos espaciais de produção no campo, há a necessidade de entender como se processa a agricultura e a pecuária. Segundo Hespanhol (2007), a mais importante atividade do interior do Brasil e, que necessita ser repensada as políticas públicas emergenciais, uma vez que o campo, atualmente, tem passado por transformações sociais, econômicas e populacionais, tornando-se 


\section{$\square$ circuito espacial de produção como instrumento de análise de desenvolvimento regional: caso da farinha de mandioca}

um espaço um tanto dinâmico. Porém, é importante destacar que esse dinamismo não é visível em todo o Território Nacional, visto que na Amazônia, particularmente no Médio Solimões, não se percebe uma transformação tão intensa. O que se observa é uma prática vinculada a uma estrutura agrária mais tradicional assentada na agricultura familiar. É percebível as transformações, mas de maneira incipiente, uma vez que, seguindo a discussão de Hespanhol (2007), as áreas rurais não apresentam um desenvolvimento expressivo, poucos são os investimentos do Estado se comparado ao agronegócio.

Com uma grande heterogeneidade no espaço rural brasileiro e a expansão do agronegócio, como ficará o agricultor familiar, na região? Será obrigado a migrar para as cidades-sedes ou se tornará assalariado do agronegócio? Partindo desses questionamentos, é fundamental discutir o circuito espacial de produção para analisar o espaço agrário no Médio Solimões, considerando que este relaciona às diferentes atividades dentro de uma unidade; uma atividade está intimamente ligada a outra, considerando que para que se tenha produção, deve-se pensar no consumo e sem consumo não tem produção, uma vez que são etapas iniciais e finais no circuito espacial de produção.

Para se entender o circuito é necessário compreender o entrecruzamento espacial de todas as ações envolvidas no processo que para Santos $(2008$, p. 56). Neste sentido, “a divisão territorial do trabalho, ao mesmo tempo em que promove uma dispersão geográfica da atividade produtiva, fornece forças de concentração" (Arroyo, 2012), a rede se organiza e se estabelece com mais coesão.

Diante disso, identificar as concentrações e as dispersões de lugares que envolvem um circuito espacial de produção, ainda mais numa economia global contemporânea, é muito difícil, mas necessário, pois determinando os sujeitos (sujeitantes e sujeitados) ligados entre si em toda a economia, é possível revelar a distribuição desigual de valores e benefícios de desenvolvimento econômico associado, entre as diferentes etapas ao longo do circuito espacial de produção.

Os conceitos acima descritos viabilizam uma análise sobre a economia agrária do Médio Solimões, com base no circuito espacial de produção da farinha de mandioca, permitindo uma verificação sobre o planejamento para o desenvolvimento regional. Partindo deste discurso, é necessário o reconhecimento da área de estudo, seja o campo propriamente dito ou as duas áreas comparativas, que permitem identificar ou não o desenvolvimento regional. 


\section{CaracterizaÇão das ÁREAS DA PESQUISA}

A pesquisa se desenvolveu no município de Tefé, no Amazonas, além das duas áreas comparativas, a cidade de Cruzeiro do Sul, no Acre e, Santarém, no Pará (Figura 1) que serviram de análise a partir da quantidade de produção, valor da produção, área plantada, área colhida e rendimento médio. Critérios que permitiram identificar os elementos que corroboram a falta de um planejamento para o desenvolvimento regional, no centro amazonense.

Figura 1 - Municípios produtores de farinha da mandioca na Pan-Amazônia.

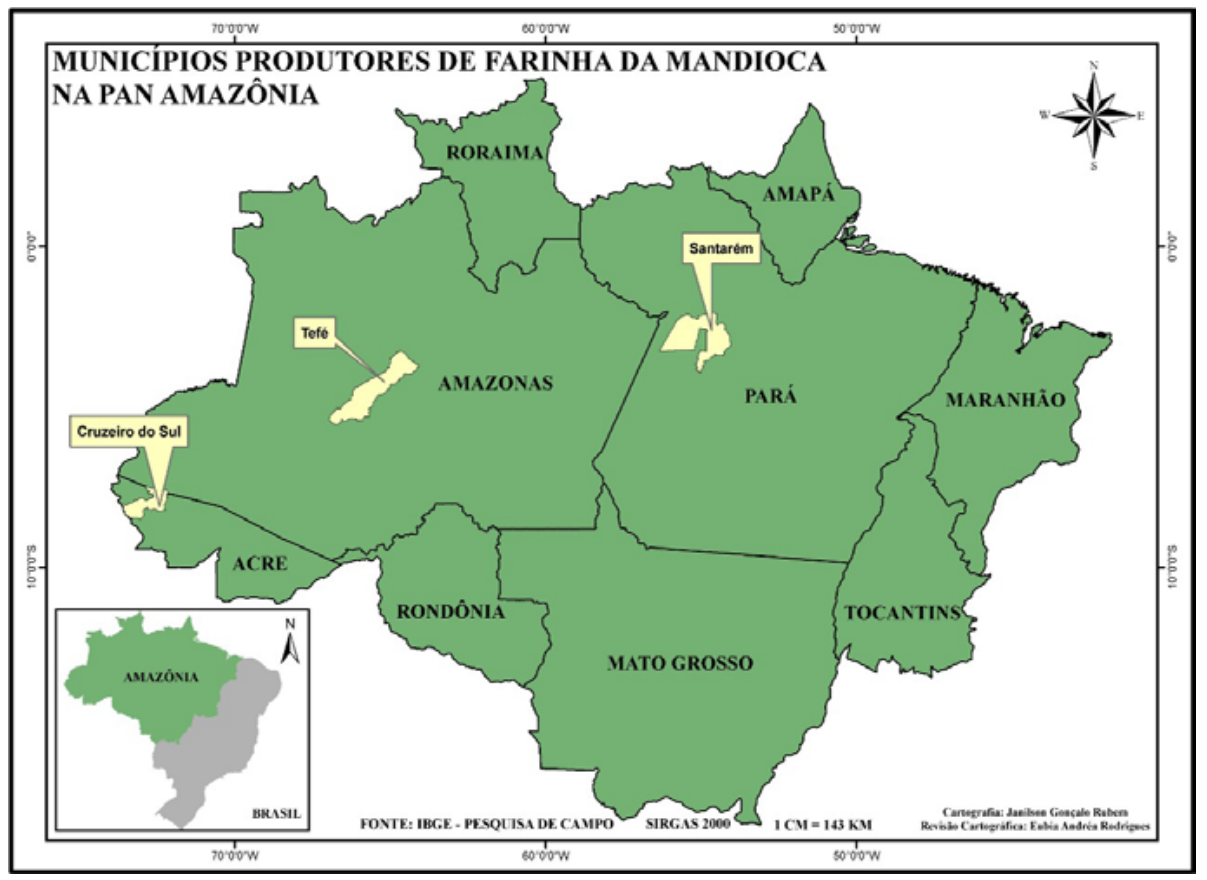

Fonte: IBGE, 2000.

\section{Tefé (AM)}

A situação geográfica do município de Tefé hoje, compreende a área localizada entre as coordenadas geográficas $03^{\circ} 15^{\prime} 39^{\prime \prime}$ a $05^{\circ} 34^{\prime} 22^{\prime \prime}$

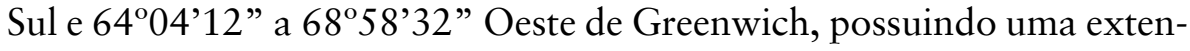




\section{$\square$ circuito espacial de produção como instrumento de análise de desenvolvimento regional: caso da farinha de mandioca}

são territorial de $23.704 \mathrm{~km}^{2}$, tendo sua área urbana localizada à margem direita da foz represada do Rio Tefé, que deságua no lago com o mesmo nome, limitando sua porção Oeste, Noroeste e Norte (Silva, 2009).

No processo de organização hierarquizada, na estruturação urbana, percebe-se que a cidade é uma área de atração do capital industrial, fazendo surgir uma sociedade totalmente desigual ou diferenciada, mas com a conexão através dos fluxos comerciais e de pessoas, por vias fluvial, aérea e terrestre, permitindo a integração dos diferentes espaços, favorecendo uma tipologia também diferenciada, no recorte espacial regional. Portanto, se Tefé consolidou sua função de "entreposto comercial", aliado a outras variáveis institucionais, cabe então a denominação de "cidade média de responsabilidade territorial", que segundo Schor e Costa, "é detentora de arranjos institucionais importantes entre si e para as cidades ao seu redor, cuja importância decorre do valor agregado pelo desenvolvimento histórico-geográfico da rede urbana" (2011) reprodução socioeconômica do espaço tefeense. Para a compreensão da função econômica que Tefé exerce hoje, na região do Médio Solimões, é necessário entender como se desenvolveu e desenvolve a articulação entre os diferentes lugares que compõem esta área, considerando que as transformações econômicas, políticas e sociais ocorridas, sempre privilegiaram Tefé em decorrência de sua história econômica e política.

É viável fazer uma caracterização geográfica, dando prioridade a atividade comercial, com base nas orientações e procedimentos das instituições de pesquisas (IBGE, ReCiMe, Nepecab), além das pesquisas in loco, para a realização de uma análise consistente. Este capítulo prioriza um estudo mais aprofundado da caracterização comercial de Tefé atual, relacionando-o com os dados e pesquisas históricas para, posteriormente, defender a proposta da tipificação urbana para o Amazonas, estabelecida pelos pesquisadores do Nepecab, uma vez que o núcleo a tipificou de "cidade média de responsabilidade territorial" (Schor, 2008). A situação geográfica do município de Tefé hoje, compreende a área localizada entre as coordenadas geográficas $03^{\circ} 15^{\prime} 39^{\prime \prime}$ a $05^{\circ} 34^{\prime} 22^{\prime \prime}$ Sul

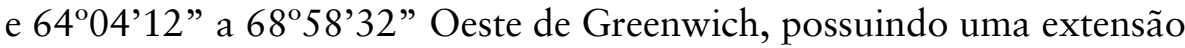
territorial de $23.704 \mathrm{~km}^{2}$, tendo sua área urbana localizada à margem direita da foz represada do Rio Tefé, que deságua no lago com o mesmo nome, limitando sua porção Oeste, Noroeste e Norte (Silva, 2009).

Considerando sua localização no centro amazonense (Figura 1), sua articulação é limitada pelos transportes fluvial e aéreo, que proporcionam uma integração coesa entre as diferentes cidades da região do 


\section{Geografia, território e sociedade na Amazônia}

Médio Solimões, uma vez que a caracterização hidrográfica da região a particulariza. Sua hidrografia permite uma aproximação entre as cidades, sendo fortalecida pelo processo de urbanização que promove um dinamismo constante entre os lugares. Segundo Silva (2009, apud Embrapa, 1999, s.d.):

A hidrografia do município merece destaque, uma vez que este
sistema, em conjunto com o aeroporto, é responsável pela inte-
gração de Tefé ao resto do Estado. Ao norte o município é
banhado pelo rio Solimões e a noroeste pelo rio Tefé, acidente
geográfico conhecido como lago de Tefé. Além deste sistema
de drenagem principal, a área que constitui a planície de inun-
dação é formada por vários furos que permitem intercomuni-
cação com o rio Solimões, facilitando o tráfego de pequenas
e médias embarcações. Observa-se o desenvolvimento de uma
pequena rede de drenagem dendrítica e subdentrítica sobre os
interflúvios tabulares.

Embora o transporte fluvial e aéreo priorize o fluxo interurbano, o terrestre corrobora com a articulação interna, considerando que o espaço urbano também é ligado ao rural por via terrestre. Para explicar esse fato, tomemos como exemplo as comunidades rurais localizadas a sudoeste da cidade, ao longo das estradas da Agrovila e Emade (Comunidade da Vila da Emade, Comunidade da Agrovila, Comunidade do Maranata, Comunidade do Pavão e Comunidade de São Francisco).

\section{Cruzeiro do Sul (AC)}

É um município do estado do Acre, sendo o mais importante pólo econômico do interior do Estado, fundado em 1904, quando sede do departamento do Alto Juruá foi transferida para Cruzeiro do Sul, situa-se na Região Geográfica Intermediária de Cruzeiro do Sul e Região Geográfica Imediata de Cruzeiro do Sul. A área do município é de $7924,94 \mathrm{~km}^{2}$ e a área urbana é de 24,794 km². Faz divisa com o estado do Amazonas (norte); o município de Porto Walter (ao sul); com Tarauacá (a leste) e com os municípios de Mâncio Lima, Rodrigues Alves e com o Peru (a oeste).

Cruzeiro do Sul é o segundo município mais populoso do Estado, com uma população de 87.673 habitantes de acordo com estimativas de 2018 do Instituto Brasileiro de Geografia e Estatística (IBGE). O município é o segundo mais populoso do Estado e o $33^{\circ}$ da região Norte 


\section{$\square$ circuito espacial de produção como instrumento de análise de desenvolvimento regional: caso da farinha de mandioca}

do Brasil. Apresenta uma densidade populacional de 11,06 habitantes por $\mathrm{km}^{2}$. Segundo o censo de $2000,50,14 \%$ da população urbana são homens e $49,86 \%$ mulheres, e $72,17 \%$ da população vive na zona urbana e $27,83 \%$ vive na zona rural. Segundo o Atlas do Desenvolvimento Humano no Brasil, a população de Rio Branco equivale a 0,05\% da população nacional.

Tem a farinha como o principal produto da atividade econômica municipal, sendo uma das melhores da região e muito apreciada no Sul do país. Nos últimos anos as atividades econômicas do município estão voltadas para atividades extrativistas, de agronegócios que visam produzir e comercializar bens e serviços. Essas atividades econômicas são fundamentais para o desenvolvimento sustentável da região e do homem que há décadas tenta sobreviver nesta parte remota do país e através delas as pessoas podem obter as coisas que precisam para a sua vida.

\section{SANTARÉm (PA)}

Santarém localiza-se na Mesorregião do Baixo Amazonas, na margem direita do Rio Tapajós, sendo a terceira maior cidade do estado do Pará e o principal centro socioeconômico do oeste do Estado, porque oferece melhor infraestrutura econômica e social (como escolas, hospitais, universidades, estradas, portos, aeroportos, comunicações, indústria e comércio, etc.) e possui um setor de serviços mais desenvolvido. Possui uma área de $22887,080 \mathrm{~km}^{2}$, sendo que $77 \mathrm{~km}^{2}$ estão em perímetro urbano, é um município brasileiro do Pará, o terceiro mais populoso do estado, atrás somente da capital, Belém e Ananindeua, sendo o principal centro urbano, financeiro, comercial e cultural do Oeste do Estado.

Atualmente a economia de Santarém está assentada nos setores de comércio e serviços, no ecoturismo, nas indústrias de beneficiamento (madeira, movelarias, olarias, panificadoras, agroindústrias, beneficiamento de peixe, etc.) e no setor agropecuário, que segundo o Idesp, na sua pesquisa sobre o Produto Interno Bruto dos municípios em 2008, destacou-se como maior produtor de arroz e soja do estado do Pará e como terceiro maior produtor de mandioca do Estado e o quarto do Brasil.

Atualmente a agricultura familiar é o seguimento responsável pelo abastecimento de parte considerável dos produtos que chegam à mesa dos consumidores, considerando, por isso, de grande relevância para Santarém. As principais culturas cultivadas pela agricultura familiar são: verduras e legumes, as culturas do milho, mandioca, arroz, 


\section{Geografia, território e sociedade na Amazônia}

feijão, coco, banana, café, laranja, limão, maracujá, melancia, fibra de curauá, pimenta do reino, tomate, tangerina, urucu, polpas de frutas, produção de açaí e castanha do Pará. Destacam-se ainda os produtos medicinais e aqueles voltados para a indústria de cosméticos, cumaru, óleo de copaíba, andiroba, mel de abelhas, leite de Amapá, sucuuba, jenipapo etc.

Os três municípios apresentam uma característica econômica agroextrativista, mas a produção de Tefé, em relação a agricultura familiar e a agricultura empresarial é insuficiente se comparada a dos dois municípios analisados, considerando que Cruzeiro do Sul tem a farinha de mandioca como seu principal produto de atividade econômica e Santarém tem uma diversidade de produtos que abastecem o mercado local e nacional. Dentro do segmento agrícola, a produção de farinha de mandioca não é a única.

\section{DisCUSSÃO DOS RESULTADOS}

No processo de construção do objeto de estudo, definiu-se como participantes da pesquisa: agricultores familiares, cooperados, feirantes e consumidores. O critério de seleção destes participantes voltou-se para a relação que existe entre eles e o objeto de pesquisa. No delineamento do processo de investigação, foi necessária a elaboração de um plano de pesquisa que contemplasse os procedimentos para a coleta e análise dos dados. Aqui são apresentados os procedimentos que nortearam a pesquisa:

a) Levantamento bibliográfico: com objetivo construir o embasamento teórico do tema trabalhado. Esse momento teve como finalidade utilizar-se de "dados ou de categorias teóricas já trabalhadas por outros pesquisadores e devidamente registrados. [...] O pesquisador trabalha a partir das contribuições dos autores, dos estudos analíticos constantes dos textos" (Severino, 2007, p. 122);

b) Análise documental: 1: Levantamento documental acerca da farinha de mandioca na região do Médio Solimões; 2: Levantamento de informações nos sites do Instituto Brasileiro de Geografia e Estatística (IBGE), www.ibge.gov. 


\section{$\square$ circuito espacial de produção como instrumento de análise de desenvolvimento regional: caso da farinha de mandioca}

br; 3: Levantamentos documentais e de dados secundários sobre a temática; 4: Levantamento histórico e documental;

c) Observação: Consideramos necessária a utilização da observação no desenvolvimento da pesquisa, pois possibilitou um contato pessoal e estreito da pesquisadora com o fenômeno a ser estudado. A observação direta e sistemática da realidade favorece o acompanhamento das experiências cotidianas vivenciadas pelos sujeitos, isso ajuda o pesquisador a apreender comportamentos, atitudes, opiniões e sentimentos de grupo/sujeitos responsáveis pela construção da realidade a ser investigada.

d) Entrevista: apresentou-se como instrumento básico na perspectiva de pesquisa e ajudou a elucidar questões levantadas através da observação. Utilizou-se a entrevista não estruturada incentivando sempre os depoimentos dos entrevistados, sem indução e levantamentos de dados com cruzamento com os referenciais teóricos dos processos (naturais, sociais e econômicos) da produção, assim como uso de dados oficiais (IBGE).

As categorias teóricas têm como propósito formar um conjunto de elementos para expor o circuito espacial de produção da farinha de mandioca produzida na região do Médio Solimões (AM), bem como suas necessidades de gestão. Para tanto, os fundamentos teóricos aqui expostos se constituem em recursos multidisciplinares para a análise do circuito espacial de produção e suas transformações.

A farinha de mandioca é considerada a base alimentar do homem amazônico, mesmo sendo este produto de baixo teor nutricional (Josué de Castro, Geografia da fome), mas não pode faltar na mesa do índio el ou caboclo amazônida. É um produto de origem indígena e, que quando se analisa o circuito espacial de produção, percebe-se a utilização de algumas técnicas tradicionais, mesmo que alguns agricultores familiares se utilizem de técnicas mais modernas que viabilizam uma maior produção em tempo menor.

Portanto, a prática da roça permanece a mesma, considerando que são bem antigos os seus meios de produção, que segundo Martins (2005 p. 209): "A história da roça começou na pré-história e se modificou com o passar do tempo com o acréscimo de uma série de componentes”, que considerando o circuito espacial de produção se identifica algumas atividades vinculadas à produção tradicional. Como por exemplo, a derru- 
bada e a queimada, "em que o índio e o caboclo abrem uma clareira dentro da vegetação primária ou em diferentes estágios de sucessão e ateiam fogo" (Martins, 2005 p. 209). Esse processo produtivo ainda é presente nas roças nas estradas da Agrovila e Emade, no município de Tefé.

Mas quando se trata da quantidade de produção, percebe-se uma grande diferença entre as áreas analisadas, Santarém e Cruzeiro do Sul possuem um mercado consolidado e amplo, por isso produzido em larga escala, alcançando os mercados de Belém, Manaus e Macapá, enquanto Tefé fica restrito ao mercado local, sendo vendida na Feira do Produtor Rural, ou nas margens da Estrada do Aeroporto, em que o produtor fica à mercê do atravessador. A Tabela 1 mostra que na quantidade produzida e no valor da produção, o município de Tefé ultrapassa a produção dos municípios analisados, situação que pode estar atrelada a toda uma produção agrícola, ou seja, enquanto Santarém e Cruzeiro do Sul trabalham uma cultura diversificada, Tefé tem se dedicado a produção da farinha de mandioca como o carro chefe da economia, considerando que os produtos da Feira do Produtor Rural, são provenientes de outros lugares, fora do contexto amazonense. Quando se observa o rendimento médio da produção de mandioca, mesmo que Tefé tenha uma maior quantidade produzida, seu rendimento médio é inferior se comparado a quantidade produzida, valor da produção, área plantada e área colhida dos municípios analisados.

Quadro 1 - Comparação de produção de mandioca nas áreas analisadas.

\begin{tabular}{|l|c|c|c|c|}
\hline \multicolumn{1}{|c|}{ Município } & $\begin{array}{c}\text { Cruzeiro } \\
\text { do Sul-AC }\end{array}$ & Santarém-PA & Tefé-AM & Medidas \\
\hline $\begin{array}{l}\text { Quantidade } \\
\text { produzida }\end{array}$ & 65.000 & 44.000 & 98.000 & $\mathrm{~T}$ \\
\hline $\begin{array}{l}\text { Valor da } \\
\text { produção }\end{array}$ & $18.005,00$ & $13.200,00$ & $98.000,00$ & $(\mathrm{x} 1000) \mathrm{R} \$$ \\
\hline Área plantada & 2.600 & 4.000 & 8.310 & $\mathrm{H}$ \\
\hline Área colhida & 2.600 & 4.000 & 8.290 & $\mathrm{H}$ \\
\hline $\begin{array}{l}\text { Rendimento } \\
\text { Médio }\end{array}$ & 25.000 & 11.000 & 11.821 & $\mathrm{Kg} / \mathrm{h}$ \\
\hline
\end{tabular}

Fonte: IBGE. Org.: Autora, 2021. 
$\square$ circuito espacial de produção como instrumento de análise de desenvolvimento regional: caso da farinha de mandioca

Quadro 2 - Comparação de preço da farinha de mandioca nas áreas analisadas.

\begin{tabular}{|l|c|c|c|}
\hline \multicolumn{1}{|c|}{ Município } & Preço saca 60kg R\$ & Preço litro R\$ & Preço kg R\$ \\
\hline Cruzeiro do Sul-AC & 200,00 & 5,00 & 7,00 \\
\hline Santarém-PA & 130,00 a 300,00* & 5,00 & 7,00 \\
\hline Tefé-AM & 280,00 a 400,00* & 4,00 a 8,00 & 8,00 \\
\hline
\end{tabular}

*Variação de preço de acordo com o tipo da farinha

Fonte: Pesquisa de campo, 2021. Org.: Autora, 2021

Quadro 3 - Valor da farinha de mandioca no município de Tefé.

\begin{tabular}{|c|c|c|c|c|}
\hline \multicolumn{5}{|c|}{ ÁREA - FIERA MUNICIPAL DE TEFÉ } \\
\hline $\mathbf{N}$ & Vendedor & Tipo/Qualidade & $\begin{array}{l}\text { Valor por } \\
\text { litro R\$ }\end{array}$ & $\begin{array}{c}\text { Valor por saca } \\
60 \mathrm{~kg} \mathrm{R \$}\end{array}$ \\
\hline 1 & José & Comum & 4,00 & 280,00 \\
\hline 2 & João & Comum & 4,00 & Não informado \\
\hline 3 & Joaquim & $\begin{array}{l}\text { Amarela } \\
\text { Boa }\end{array}$ & $\begin{array}{l}4,00 \\
4,50 \\
\end{array}$ & $\begin{array}{r}280,00 \\
320,00 \\
\end{array}$ \\
\hline 4 & Josefina & $\begin{array}{l}\text { Comum Amarela } \\
\text { Comum }\end{array}$ & $\begin{array}{l}4,00 \\
2,00 \\
\end{array}$ & $\begin{array}{l}210,00 \\
150,00 \\
\end{array}$ \\
\hline 5 & Joana & $\begin{array}{l}\text { Ovinha } \\
\text { Ovinha filé } \\
\text { Média } \\
\text { Ova de GG }\end{array}$ & $\begin{array}{l}7,50 \\
7,50 \\
7,50 \\
4,00 \\
\end{array}$ & $\begin{array}{c}400,00 \\
400,00 \\
400,00 \\
X \\
\end{array}$ \\
\hline 6 & Josimauro & $\begin{array}{l}\text { Comum } \\
\text { Média } \\
\text { Ovinha } \\
\text { Graúda }\end{array}$ & $\begin{array}{l}5,00 \\
7,80 \\
7,50 \\
5,00 \\
\end{array}$ & $\begin{array}{c}380,00 \\
400,00 \\
400,00 \\
* 1 \\
\end{array}$ \\
\hline
\end{tabular}




\begin{tabular}{|c|c|c|c|c|}
\hline 7 & Jairo & $\begin{array}{l}\text { Amarela } \\
\text { Ovinha } \\
\text { Ova média } \\
\text { Ova normal } \\
\text { Filezinha }\end{array}$ & $\begin{array}{l}5,00 \\
6,00 \\
7,50 \\
6,00 \\
8,00\end{array}$ & $* 2$ \\
\hline
\end{tabular}

Fonte: Pesquisa de campo. Org.: Autora, 2021.

O Quadro 2 apresenta a valoração do preço da farinha de mandioca, ou seja, o produto final no circuito de produção. Quando se fala em produto final, considera-se a farinha de mandioca pronta para comercialização e consumo. O quadro em questão apresenta dados colhidos em campo nas áreas pesquisadas, percebe-se que há uma homogeneidade nos preços por litro e quilograma, nas áreas de maior produção na Amazônia, havendo somente uma variação no valor da saca de $60 \mathrm{~kg}$. De acordo com as entrevistas, nos dois últimos anos, em Tefé, a farinha de mandioca tem alcançado um alto valor no mercado local, isso se deve ao momento pandêmico em que o mundo vive, pois os preços dos produtos alimentícios têm se elevado a cada semana, e com a farinha de mandioca não foi diferente, mas nem por isso o produto faltou na mesa do tefeense.

O quadro 2 está em consonância com a quadro 3, que mostra o valor da farinha de mandioca quanto à qualidade e granulação. Em se tratando de qualidade, a farinha se destaca pela coloração e tipo de mandioca, quanto a coloração é acrescida um condimento alimentar para dar uma cor mais amarela aos grãos e, quanto ao tipo de mandioca pode ser da branca ou da amarela, desta forma ela se classifica como: comum, amarela e boa (a boa se apresenta com uma variedade de grãos em tamanhos diferentes com pequenos fiapos), que para os consumidores não é de boa qualidade, por não ser bem embolada.

Em Tefé, a farinha de melhor qualidade é classificada em: ovinha, ovinha filé, ovinha norma, ova média e filezinha (Quadro 3). Esta classificação está relacionada à granulação da farinha. Existe por detrás desta produção todo um trabalho artesanal e manual que diversifica o tama- 


\section{$\square$ circuito espacial de produção como instrumento de análise de desenvolvimento regional: caso da farinha de mandioca}

nho e a perfeição do grão. A farinha ova também é denominada de farinha do "uarini", considerando que existe uma técnica de embolamento do grão e o tipo de peneira utilizada para a formatação dos grãos. Todo esse processo vai pesar no bolso do consumidor como mostra o quadro 3, uma variação de preço quanto a granulação.

Essa característica vai diferenciar a produção de Tefé se comparada à produção de Santarém e Cruzeiro do Sul, quanto à qualidade. A farinha ova de Tefé é bem apreciada, não só pelos tefeenses, mas por outras pessoas que chegam na cidade (turistas ou não) e provam a farinha que é oferecida nos restaurantes e acompanha o cardápio regional.

Um diferencial observado durante a pesquisa é que a farinha de Tefé não é certificada, sendo vendida na feira em sacos plásticos transparentes de 1 a $5 \mathrm{~kg}$ e com o preço estampado com pincel atômico. Por outro lado, a farinha de Santarém e Cruzeiro do Sul obedece às exigências do mercado, principalmente, quanto a questão da embalagem padronizada, portanto, certificada. Esse diferencial está atrelado a um resultado de uma ação conjunta de produção, ou seja, os produtores trabalham em forma de cooperativas, como por exemplo, em Santarém existe a Coopboa (Cooperativa dos Produtores da Agricultura Familiar da Comunidade Boa Esperança), com uma produção anual de 300 toneladas, com 20.790 hectares de áreas plantadas, sendo exportado para o Norte e Nordeste do Brasil.

Esta organização em cooperativas proporciona um desenvolvimento neste setor, tanto em Santarém quanto em Cruzeiro do Sul, uma vez que a organização viabiliza um maior acesso às políticas públicas, com base na Política Nacional da Agricultura Familiar (PNAF). Pensar o desenvolvimento regional para o médio Solimões a partir do circuito espacial de produção da farinha de mandioca é agir na organização dos agricultores familiares para o acesso às políticas públicas brasileiras neste setor e promover uma ação coletiva entre todas as unidades familiares de produção agrícola para a melhoria da qualidade de produção. Para que a farinha de mandioca de Tefé alcance novos mercados e tenha uma produção em larga escala, é necessário um planejamento que promova o desenvolvimento regional.

\section{CONClusão}

O desenvolvimento regional se concretiza a partir de um planejamento entre o poder público, que se destina às políticas públicas para 
se efetivarem em diferentes espaços, e poder privado, que articulados, possam promover uma qualidade de vida para a sociedade a qual está destinada. Este planejamento deve ocorrer de acordo com a ação de diferentes agentes sociais, que é uma ação conjunta e articulada para a promoção do desenvolvimento socioeconômico e ambiental, este segundo atrelado à sustentabilidade.

Partindo deste pressuposto é que se propôs a pesquisa. Uma busca de alternativa que possibilite o desenvolvimento regional e o crescimento econômico do agricultor familiar a partir do circuito espacial de produção da farinha de mandioca, na região do médio Solimões.

Aqui se tem uma discussão sobre desenvolvimento regional para o médio Solimões, mas é necessário um estudo mais aprofundado que permita uma ação mais efetiva do poder público, privado e sociedade civil para um bem comum, que é o desenvolvimento da Amazônia em diferentes dimensões.

\section{REFERÊNCIAS}

ARROYO, Mônica. Circuitos espaciais de produção industrial e fluxos internacionais de mercadorias na dinâmica territorial do estado de São Paulo. In: Boletim Campineiro de Geografia, Campinas, v. 2, n. 1, p. 7-26 fev. 2012.

BRASIL. Presidência da República. Decreto n. 9.064, de 31 de maio de 2017. Dispõe sobre a Unidade Familiar de Produção Agrária, institui o Cadastro Nacional da Agricultura Familiar e regulamenta a Lei n. 11.326, de 24 de julho de 2006, que estabelece as diretrizes para a formulação da Política Nacional da Agricultura Familiar e empreendimentos familiares rurais. Brasília, 2017. Disponível em: www.planalto. gov.br/ccivil_03/_Ato2015-2018/2017/Decreto/D9064.htm. Acesso em: 3 abr. 2019.

CASTRO, Josué. Geografia da fome: o dilema brasileiro - pão ou aço. Rio de Janeiro: Edições Antares, 1984.

CHAYANOV, Alexander V. La organización de la unidad economica campesina. Bueno Aires: Ediciones Nueva Vision, 1974.

GIDDENS, Anthony. As consequências da modernidade. São Paulo: Editora Unesp, 1991.

JUNIOR, Caio Prado. História Econômica do Brasil. Editora Brasiliense. 1970 
MARTINS, Paulo Sodero. Dinâmica evolutiva em roças dos caboclos amazônicos. Estudos Avançados 19 (53), 2005. Texto publicado originalmente em VIEIRA, Célia Guimarães et al. (orgs.). Diversidade biológica da Amazônia. Belém, Museu Paraense Emílio Goeldi, 2001, p. 269-384.

MARTINS, José de Souza. O cativeiro da terra. São Paulo: Editora Contexto, 1979.

NEVES, Delma Peçanha. Agricultura familiar: quantos ancoradouros! In: FERNANDES, Bernardo Mançano; MARQUES, Marta Inez M.; SUZUKI, Júlio Cesar. Geografia agrária: teoria e poder. São Paulo: Expressão Popular, 2007.

NEVES, M. F., CASTRO, L. T. O Método para construção de um projeto integrado de negócios sustentáveis. In: Neves, M. F., CASTRO, L. T. Agricultura integrada inserindo pequenos produtores de maneira sustentável em modernas cadeias produtivas. São Paulo, Atlas, 2010.

MONTEIRO. N., Aristides. Desenvolvimento regional em crise: políticas econômicas liberais e restrições à intervenção no Brasil dos anos 1990. 2005. Tese (Doutorado) - Instituto de Economia, Universidade Estadual de Campinas, Campinas, 2005.

OLIVEIRA, Ariovaldo Umbelino de. Modo capitalista de produção e agricultura. São Paulo: Ática, 1990.

OLIVEIRA, Ariovaldo Umbelino de. A Agricultura camponesa no Brasil. 4. ed. São Paulo: Contexto, 2001. (Caminhos da Geografia)

A Geografia Agrária e as transformações territoriais recentes no campo brasileiro. In: CARLOS, Ana Fani (Org). Novos caminhos da Geografia. São Paulo: Contexto, 2007.

OLIVEIRA, A. U de. A longa marcha do campesinato brasileiro: movimentos sociais, conflitos e Reforma Agrária. Estudos Avançados, n. 43, volume 15, set/dez. 2001, p. 185-206.

PLOEG, J. D. V. D. Camponeses e impérios alimentares: lutas por autonomia e sustentabilidade na era da globalização. Porto Alegre: UFRGS Editora, 2008.

Camponeses e a arte da agricultura: um manifesto chayanoviano; tradução Claudia Freire. São Paulo; Porto Alegre: Editora Unesp; Editora UFRGS, 2016.

Projeto Cooperativismo SAF/UFV - Curso 4. Política Pública e Agricultura Familiar, UFV, 2018. p. 15. 
ROMEIRO, Ademar Ribeiro. Meio ambiente e dinâmica de inovações na agricultura. São Paulo. Atlas, 2008

SANTOS, Milton. O espaço dividido: os dois circuitos da economia urbana dos países subdesenvolvidos. São Paulo: Edusp, 2008

Por uma Geografia Nova. São Paulo: Edusp, 2008.

Metamorfoses do espaço habitado: fundamentos teóricos e metodológicos da geografia. Editora Hucitec. São Paulo, 1997.

SEVERINO, Antonio Joaquim. Metodologia do Trabalho Científico. 23. ed. São Paulo: Cortez, 2007.

SCHOR, Tatiana. Reflexões metodológicas sobre o estudo da rede urbana no Amazonas e perspectivas para a análise das cidades na Amazônia brasileira. Revista Acta Geográfica. 2011. 


\title{
REGULARIZAÇÃO FUNDIÁRIA NA AMAZÔNIA LEGAL: LIMITAÇÕES E EXPECTATIVAS NA GOVERNANÇA DA TERRA
}

\author{
Alyson Fernando Alves Ribeiro" \\ Hervé Émilien René Théry"* \\ Ricardo Gilson da Costa Silva***
}

\section{INTRODUÇÃO}

$\mathrm{Na}$ contingência de agir para alterar, o projeto de modernização econômica e sua retórica de progresso transformou aquele "território vazio", chamado Amazônia, em uma área, um receptáculo (en)cantado, mitificando-o há anos como uma região homogênea. Uma frente discursiva que empolgou com a visão sobre a região, pautada no contraste entre a beleza e a abundância, contemplando-a como Natureza, como Floresta, como "atrasada", como Reserva de Recursos, como o futuro do Brasil (Porto-Gonçalves, 2001; Becker, 2005; Mello-Thery, 2006; 2011). Esse apólogo alegórico da Amazônia confronta com a visão da região, desnudada em um presente espacial vivo, fruto da relação homem-natureza, uma (re)produção social histórica materializada em espaços e transmutada em uma diversidade de territórios envolto em disputas políticas entre os diferentes sujeitos sociais, Estado e empresas.

Um primeiro passo para avançar no conhecimento sobre a região é dissipar os mitos e as representações simplificadas que a envolvem. A Amazônia é parte do Brasil, e seus problemas decorrem das contradições intrínsecas ao modo de inserção do país no sistema capitalista mundial e a acelerada reorganização da sociedade brasileira, embora com feições particulares devido às especificidades regionais (Becker, 2005, p. 223).

\footnotetext{
https://orcid.org/0000-0003-0731-9973

** https://orcid.org/0000-0001-8282-3470

*** https://orcid.org/0000-0002-3348-9629
} 
Um dos maiores problemas da Amazônia Legal cristaliza-se no caos fundiário, decorrente da ocupação agrário-territorial desordenada. Os conflitos no campo surgem, dentre outros motivos, pela emblemática questão agrária brasileira, sendo um processo inerente da luta pela terra na Amazônia Legal: afinal, quem é o dono da terra?

Nessa geografia social, de um lado, estão os camponeses, indígenas, comunidades tradicionais amazônicas, quilombolas e, do outro, encontram-se grileiros, fazendeiros, empresas agropecuárias, madeireiros, mineradores e, mais recentemente, empresas associadas ao capital internacional que disputam a apropriação privada dos recursos naturais da Amazônia (Ribeiro; Costa Silva; Lisboa, 2016).

Nesse caminho aberto, o presente texto busca analisar a institucionalização do projeto Regulariza Amazônia de cooperação entre o Brasil e a União Europeia e suas interfaces com a governança da terra. A intencionalidade é apresentar o projeto, desvelando sua relação intrínseca com o Programa Terra Legal Amazônia, ao desvelar limites e perspectivas de um programa bilateral com vistas à gestão do território na Amazônia brasileira, com enfoque estratégico na regularização fundiária, em terras públicas devolutas pertencentes à União.

$\mathrm{Na}$ primeira parte do texto trataremos da regularização como caminho no trilhar da governança da terra, na segunda parte apresentaremos a conjuntura e os desdobramentos em curso do Projeto Regulariza Amazônia, e por último, em considerações finais, anteveremos que o projeto poderá impulsionar o mercado de terras em escala global, ao colocar a terra como ativo liquido, que pode ser usada para fins produtivos e especulativos, fomentando o mercado imobiliário de terras a serem consumidas pelo agrohidronegócio mundanizado.

\section{A Regularização COMO ALTERnATIVA DE GOVERnANÇA DA TERRA}

Hodiernamente, a situação fundiária da Amazônia é a seguinte: dos seus 501.600 .000 hectares, 120 milhões são de terras públicas. Desse montante, 63 milhões são de terras destinadas e 57 milhões de hectares a destinar (Tabela 1, Figura 1, Figura 2). Essas áreas são correspondentes a terras sob a jurisdição da União, ocupadas informalmente por agricultores, e sem o precedente do título de propriedade. 


\section{Regularização fundiária na Amazônia legal}

Tabela 1 - Amazônia Legal: descriminação/destinação da terra (2019).

\begin{tabular}{|l|c|}
\hline Destinação da terra & Área (hectares) \\
\hline Terras indígenas & 120,1 milhões hectares \\
\hline Unidades de Conservação & 43,9 milhões de hectares \\
\hline Área Militar & 5,53 milhões hectares \\
\hline Assentamentos & 33,3 milhões hectares \\
\hline Quilombolas & 1,07 milhões hectares \\
\hline Imóveis certificados & 21,4 milhões hectares \\
\hline Glebas Públicas Federais & 120 milhões hectares \\
\hline Área Destinada Sobre Gleba Federal & 63 milhões hectares \\
\hline Área Não Destinada Sobre Gleba Federal & 57 milhões hectares \\
\hline
\end{tabular}

Fonte: Brasil, Serfal, 2019. Elaboração: Alyson Ribeiro, 2020.

Figura 1 - Descriminação da terra (áreas em milhões de hectares) na Amazônia Legal (2019).

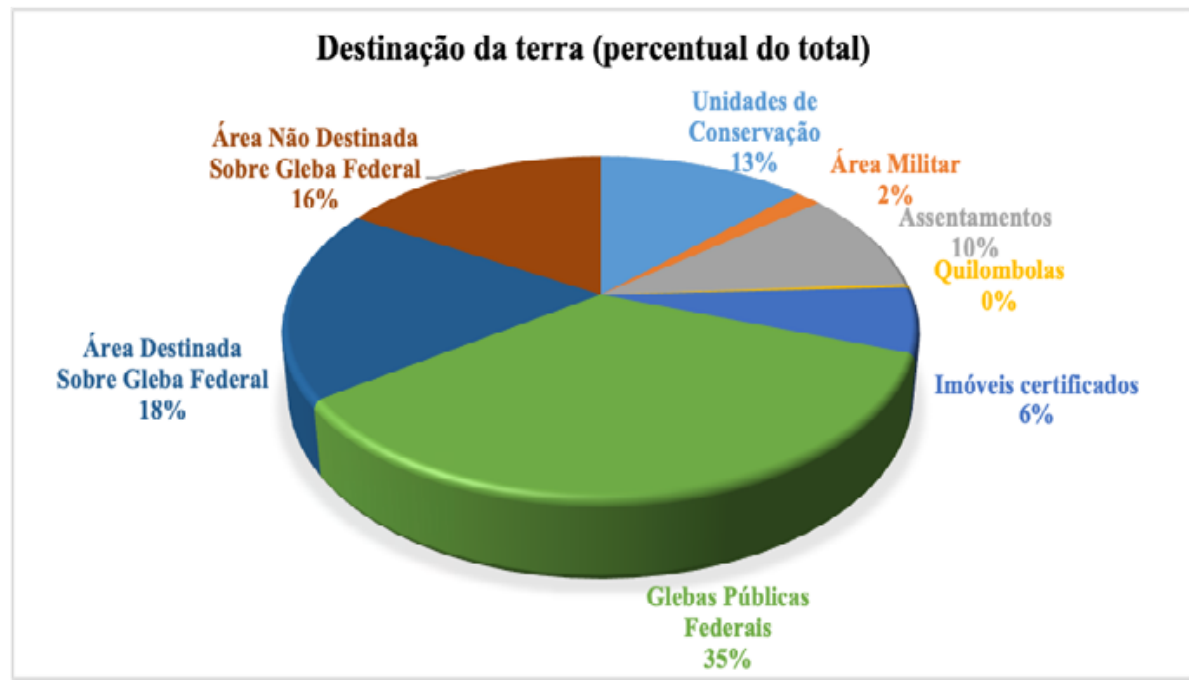

Fonte: Brasil, Serfal, 2019. Elaboração: Alyson Ribeiro, 2021. 
Figura 2 - Estrutura fundiária da Amazônia Legal.

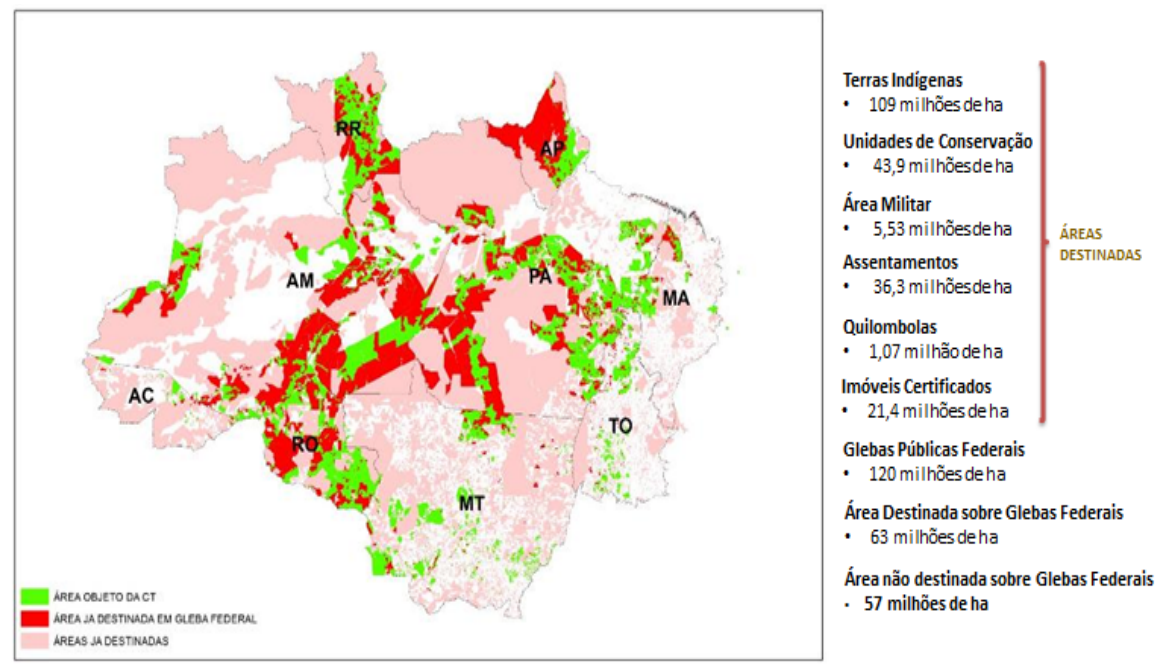

Fonte: Departamento de Planejamento - Brasil, Serfal, 2019.

A regularização fundiária é um instrumento de cunho político-jurídico que tem como foco principal a legalização e destinação de terras públicas. Trata-se do reconhecimento do direito de posse que as famílias têm por utilizarem terras públicas devolutas há décadas pela concessão de títulos de propriedade. A regularização fundiária busca converter a posse física do agricultor em posse jurídica, conferindo-lhe, assim, o título da terra (Ribeiro, 2020).

A governança da terra traduz a união de mecanismos de ordenamento, planejamento e gestão do território, mediante junção de estratégias para o desenvolvimento sustentável dos ativos públicos produtivos (biodiversidade, ar, água, terra, subsolo) de uma nação.

Por gobernanza se entiende el proceso de gobernar; es la forma en que la sociedad es administrada y em que se reconcilian las prioridades e intereses contrapuesto de diferentes grupos. Se incluye aquí a las instituciones gubernamentales oficiales pero también a los acuerdos no oficiales. La gobernanza se ocupa de los procesos mediante los cuales los ciudadanos participan en la toma de decisiones, los gobiernos rinden cuentas a los ciudadanos y la sociedad obliga a sus miembros a observar las normas y las leyes (FAO, 2007, p. 7). 


\section{Regularização fundiária na Amazônia legal}

A regularização fundiária, como mecanismo jurídico de governança para o reordenamento territorial, configura-se em uma dimensão instrumental e institucional de gestão da terra pública. Seus aspectos básicos, jurídicos e institucionais são: cumprimento da função social da propriedade, realizar georreferenciamento do imóvel, ter ocupação mansa e pacífica e não titular proprietários de outros imóveis rurais.

A governança é um conceito que compreende complexos mecanismos, processos e instituições por meio dos quais os cidadãos e os grupos articulam seus interesses e exercem seus direitos e obrigações legais. Por extensão, a governança da terra compreende normas, processos e organizações mediante os quais se adotam decisões relativas ao uso e ao controle da terra, a tomada de decisões e a forma como se administram interesses contrapostos relativos à terra. $\mathrm{O}$ conceito de governança abarca tanto os marcos jurídicos e normativos sobre a terra como as práticas tradicionais e informais que contam com legitimidade social (Reydon; Fernandes; Bueno, 2017, p. 24)

A governança da terra por via da regularização fundiária emerge como um tema importante quando entendemos que o Brasil, em especial a Amazônia brasileira, é uma região com volume considerável de terras devolutas. Representa a condição de "fôlego territorial" para a dinâmica de expansão das atividades agropecuárias, volta para a territorialização e produção de commodities e minerais em escala global e local (Mello-Therry, 2006 e 2011).

\section{Projeto regulariza Amazônia: COOPERAÇão bilateral brasil-UNião EUROPEIA}

A situação fundiária de cerca de metade da Amazônia Legal é incerta. A região engloba uma superfície de, aproximadamente, 501.600.000 de hectares, correspondentes a cerca de $60 \%$ do território brasileiro. Desses hectares, ainda existem 57 milhões a destinar.

No Brasil, muitos direitos sobre a terra não estão legalmente reconhecidos e tampouco documentados, particularmente na região da Amazônia Legal, na faixa de fronteira do país, onde ainda prevalecem remanescentes de terras públicas ou devolutas, estaduais e federais. É possível verificar o avanço nas políticas de regularização fundiária e a inovação normativa e tecnológica, mas atualmente milhares de famílias ainda vivem 


\section{Geografia, território e sociedade na Amazônia}

sem o reconhecimento legal das ocupações em terras públicas, e milhões de propriedades cadastradas nos sistemas oficiais do Governo estão com informações desatualizadas e desvinculadas dos Cartórios de Registros de Imóveis (Reydon; Fernandes; Bueno, 2017, p. 24)

O projeto Regulariza Amazônia, de cooperação entre o Incra e a União Europeia, promove uma parceria internacional na esfera de atuação da governança da terra. A delegação europeia, que faz parte da estrutura organizacional do Projeto Regulariza Amazônia, promoveu contratação de consultoria para aprimorar a governança de terras públicas devolutas na Amazônia brasileira.

Segundo Mello-Théry (2011), terras públicas são terras pertencentes ao poder público (unidades de conservação, áreas destinadas à reforma agrária, áreas arrecadadas pelas forças armadas, terras indígenas, etc.), as quais são bens determinados que integram o patrimônio público, incluindo-se aí as terras devolutas.

Devoluta é toda terra que, por qualquer título, não se acha aplicada a nenhum uso público por um lado, e, por outro, não integrado por qualquer título ao patrimônio privado. Elas são, portanto, hoje, indeterminadas. [...] Assim, as terras devolutas são uma espécie de terras públicas lato sensu. A outra espécie, são terras públicas scrito sensu. (Mello-Therry, 2011, p. 83).

Essa colaboração entre o governo brasileiro e a União Europeia visa à regularização de terras públicas devolutas pertencentes à União; nos estados selecionados da Amazônia Legal, ao colocar em prática um plano de diretrizes operacionais de assistência no tocante ao (re)ordenamento fundiário territorial da Amazônia. O objetivo específico é aprimorar e acelerar o processo de destinação e regularização fundiária de terras públicas no âmbito do programa Terra Legal em quatro estados: Pará, Mato Grosso, Amazonas e Amapá (Incra, 2020).

O Programa Terra Legal Amazônia foi elaborado pelo Governo Federal, em 2009, durante o governo de Luiz Inácio Lula da Silva, dentro das diretrizes do Plano Amazônia Sustentável (PAS) ${ }^{14}$, que estabelece

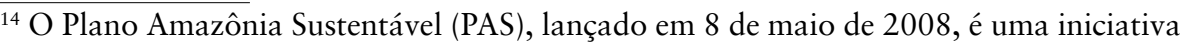
dos governos dos sete estados da Região Norte, incluindo o Mato Grosso e o Maranhão, pela necessidade de compreensão do contexto mais amplo do desenvolvimento da re-
} 


\section{Regularização fundiária na Amazônia legal}

como um dos entraves estruturantes para o avanço de políticas que se fundamentam em um modelo de desenvolvimento sustentável na região, a indefinição de direitos fundiários na Amazônia.

O Programa Terra Legal Amazônia é coordenado e executado por meio da Secretaria Extraordinária de Regularização Fundiária na Amazônia Legal (Serfal). O programa tem por objetivo regularizar posses em terras da União (glebas federais) ocupadas por posseiros dos nove estados da Amazônia Legal que possuam posses até o limite de dois mil e quinhentos (2.500) hectares (Brasil, 2009). As glebas públicas federais do território da Amazônia Legal constituem o alvo deste programa de regularização fundiária, que visa reconhecer o direito à propriedade dos posseiros que se estabeleceram durante anos em terras da União.

A intenção do Programa Terra Legal é regularizar as ocupações legítimas com prioridade aos pequenos produtores e às comunidades locais. Objetiva com a entrega do título de propriedade, garantir a segurança jurídica aos posseiros, reforçando políticas públicas de desenvolvimento sustentável. No entanto, a ausência do cadastro e a expedição de diferentes espécies de títulos provisórios e definitivos, além da ausência de dados confiáveis, não permitiam afirmar, com certeza, a proporção ocupada por essa categoria, o que acabava estimulando os conflitos sociais, as apropriações e a especulação de esquemas de titulação fraudulenta eivada de ilegalidades (Brito; Barreto, 2011).

Para regularizar a posse, o programa Terra Legal Amazônia, em tese, trabalha com as principais etapas: georreferenciamento; requerimento; cadastro e titulação (Brasil, Serfal, 2019) (Figura 3).

gião. O plano tem como objetivo definir as diretrizes para o desenvolvimento sustentável na Amazônia Brasileira (Brasil, 2008). 
Figura 3 - Etapas da gestão de terras públicas da Amazônia Legal do Programa Terra Legal (2021).
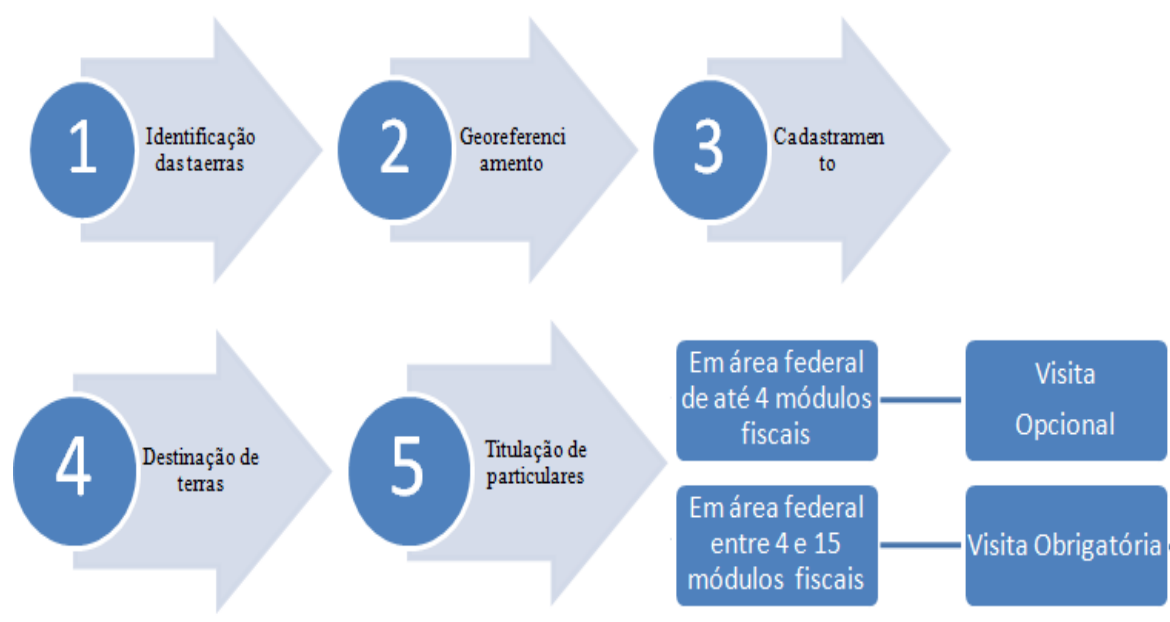

Fonte: Brasil, Serfal, 2020. Elaboração: Alyson Ribeiro.

A primeira etapa é a identificação das terras. É realizada a verificação do(s) registro(s) junto ao(s) Cartório(s) de Registro de Imóveis. $\mathrm{Na}$ sequência se inicia o processo de identificação das áreas já destinadas e tituladas bem como a quantidade de áreas ainda não destinadas. A segunda etapa é o georreferenciamento, que consiste na medição precisa e segura de parcelas das áreas públicas federais não destinadas, ocupadas por posseiros ou que possuem interesse manifestado para uso público (Brasil, 2009).

O cadastramento se constitui na terceira etapa. É centrado na identificação do ocupante, formalização do requerimento e recolhimento de documentos necessários. A quarta etapa é a definição da destinação das terras. A lei 11.952/09 determina que o MDA faça a consulta aos órgãos SPU, MMA (ICMBio, SFB), Funai, Incra e Estados, para que se manifestem sobre o interesse ou não na área a ser destinada. A Titulação de particulares é a última etapa da regularização fundiária agrária. Consiste na junção do georreferenciamento e do cadastro formando o processo, que passa por análise e, sendo atendidos todos os critérios 


\section{Regularização fundiária na Amazônia legal}

previstos na Lei 11.952/09, permite a emissão do título em nome do requerente (Brasil, 2009).

A entrega do título, de acordo com Lei 11.952, de 25 de junho de 2009, marco legal do PTLA dispõe sobre a regularização fundiária das ocupações de terras devolutas no território da Amazônia Legal. Seguem, abaixo, os seguintes critérios:

$\mathrm{Na}$ ocupação de área contínua de até um módulo fiscal, a alienação e, a concessão de direito real de uso dar-se-ão de forma gratuita, dispensada a licitação (Art. 11). Na ocupação de área contínua acima de um módulo fiscal e até o limite previsto a alienação e, a concessão de direito real de uso dar-se-ão de forma onerosa, dispensada a licitação (Art. 12); O preço do imóvel considerará o tamanho da área e será estabelecido entre $10 \%$ (dez por cento) e $50 \%$ (cinquenta por cento) do valor mínimo da pauta de valores da terra nua para fins de titulação e regularização fundiária elaborada pelo Incra, com base nos valores de imóveis avaliados para a reforma agrária, conforme regulamento(\$1) Serão acrescidos ao preço do imóvel para alienação os custos relativos à execução dos serviços topográficos, se executados pelo poder público, exceto quando se tratar de ocupações cujas áreas não excedam a quatro módulos fiscais (Art.12 \$3o); As áreas ocupadas insuscetíveis de regularização por excederem o limite previsto serão condicionadas à desocupação da área excedente. (Brasil, 2009)

O projeto Regulariza Amazônia promove um intercâmbio internacional na esfera da governança da terra e desenvolvimento territorial sustentável ao disponibilizar as ferramentas tecnológicas para integrar e automatizar o processo de cadastramento, modernização do acervo, georreferenciamento, titulação e destinação de terras devolutas. O projeto, em seu conjunto, busca reforçar o processo de regularização fundiária, mitigando, assim, fraudes e apropriações indébitas de terras públicas devolutas da União.

O Projeto Regulariza Amazônia foi implantado no final de 2017 e tem duração de quatro anos, com previsão de finalização no ano de 2021. Sua implementação é de responsabilidade de um consórcio formado por três instituições, de acordo com o Instituto Brasileiro de Colonização e Reforma Agrária (Incra): GFA Consulting Group, uma empresa de consultoria alemã com sede na cidade de Hamburgo. A empresa atua desde 1982 e já implementou projetos e estudos em mais de 130 países 


\section{Geografia, território e sociedade na Amazônia}

para agências de desenvolvimento, líderes, ministérios e clientes públicos (Incra, 2020).

Instituto Internacional para a Educação do Brasil (IEB), uma instituição brasileira do terceiro setor dedicada a formar e capacitar pessoas, bem como fortalecer organizações nas áreas de manejo dos recursos naturais, gestão ambiental e territorial e outros temas relacionados à sustentabilidade. O IEB atua em rede, busca parcerias e promove situações de interação e intercâmbio entre organizações da sociedade civil, associações comunitárias, instâncias de Governo e do setor privado. Como uma organização de ações educativas, incorpora os saberes de parceiros, as diferentes culturas e as técnicas populares (Incra, 2020).

Dr. Schindler Geo Consult International GmbH \& Co, uma empresa de administração de terras, gestão de terras, levantamento topográfico e sistemas de informação geográfica (SIG) (Incra, 2020).

A cooperação em escala internacional, no âmbito do (re)ordenamento do território, não é novidade no tocante à formulação e implementação de políticas territoriais na Amazônia Legal. É uma prática consolidada na região. Em contrapartida, o diferencial na cooperação bilateral Brasil-União Europeia na esfera operacional do Projeto Regulariza Amazônia é o enfoque estratégico no apoio à política de regularização fundiária como subsídio ao desenvolvimento sustentável.

Segundo os termos de referência do Projeto Regulariza Amazônia, essa cooperação no âmbito do (re)ordenamento fundiário do território apresenta os seguintes componentes operacionais (Incra, 2020):

- Metodologias aperfeiçoadas e inovações aplicadas à gestão fundiária;

- Acesso de produtores da agricultura familiar às políticas públicas para o desenvolvimento sustentável promovido;

- Metodologia da regularização fundiária sistematizada e disseminada;

- Desenvolvimento de mecanismos de governança entre as esferas federal e estadual em apoio ao processo de regularização fundiária.

O Projeto foi idealizado para aprimorar e acelerar o processo de regularização fundiária de terras públicas no âmbito do programa Terra Legal. Para concretizar esse intento, ele apresenta uma estrutura organi- 


\section{Regularização fundiária na Amazônia legal}

zacional que busca fornecer suporte e monitoramento da regularização fundiária, sendo composta por: Gesellschaft für Internationale Zusammenarbeit $(\mathrm{GIZ})^{15}$, comitê internacional, articulação entre Instituto de colonização e Reforma Agrária, Incra e Ministério da Agricultura, Pecuária e Abastecimento (MAPA), delegação europeia e consócio (Figura 4).

Figura 4 - Estrutura organizacional do projeto Regulariza Amazônia (2020).

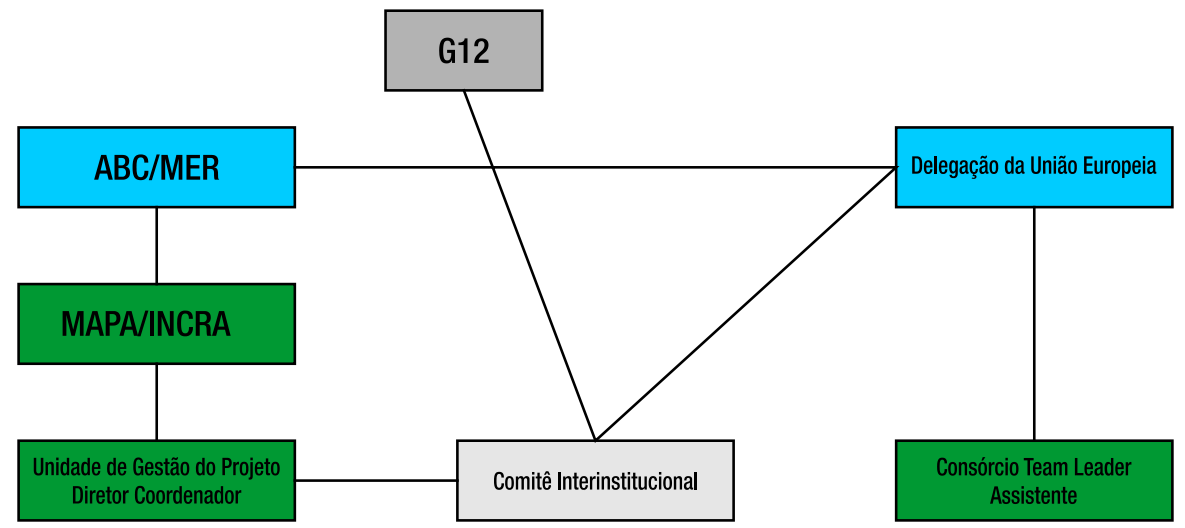

Fonte: Incra, 2020.

A delegação europeia, que faz parte da estrutura organizacional do Projeto Regulariza Amazônia, promoveu contratação de consultoria para aprimorar o módulo "titulação" do Sistema de Gestão Fundiária (Sigef).

O Sistema de Gestão Fundiária (Sigef) foi desenvolvido para subsidiar a governança fundiária do território nacional. Com esse sistema, o processo de certificação de propriedades no Brasil foi automatizado, o que elimina a análise humana sobre o processo e, se aprovado, emite a certificação automaticamente (Ribeiro, 2016).

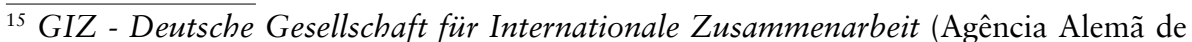
Cooperação Internacional) é uma empresa privada internacional fundada em 1975 por Erhard Eppler e tem hoje como principal acionista o Governo Federal Alemão. A empresa é especializada em projetos de cooperação técnica e de desenvolvimento sustentável em escala mundial. Sua sede fica na cidade alemã de Eschborn. 


\section{Geografia, território e sociedade na Amazônia}

É cada vez mais frequente a cobrança por políticas de desenvolvimentos sustentáveis na região. Países que possuem terras no território pan-amazônico estão sendo cada vez mais cobrados e pressionados a colocar em pauta, sobretudo, ações de contenção, principalmente aos desmatamentos

O grupo de países da União Europeia, denominado Parceria das Declarações de Amsterdã ${ }^{16}$ atualmente liderado pela Alemanha, emitiu uma carta em 16 de outubro de 2020, ao governo brasileiro, com o intuito diplomático de estabelecer uma agenda comum para garantia de um desenvolvimento próspero e sustentável para o Brasil e principalmente para Amazônia:

Os governos brasileiro e europeu vêm há muito tempo desenvolvendo uma cooperação estreita visando o benefício mútuo bem como o bem de nossos cidadãos. A Parceira das Declarações de Amsterdã está comprometida em buscar cadeias de suprimento de produtos agrícolas sustentáveis e não associadas ao desflorestamento para nossos países - o que consideramos importante para a nossa iniciativa bilateral individual, bem como para outras iniciativas multilaterais importantes no sentido de intensificar os esforços para conservar, restaurar e manejar de maneira sustentável às florestas em todo o planeta (Parceria das Declarações de Amsterdã, 2020, p. 2).

Este cenário é relevante, pois trata de um momento histórico em que a (re)produção do espaço da Amazônia tem como vetor a generalização da mercantilização da natureza, em proporções nunca vistas em seu processo de (des)ocupação territorial.

Essa cooperação bilateral Brasil-União Europeia insere-se como alternativa para a governança da terra com enfoque no desenvolvimento sustentável. O Projeto está em seu terceiro ano de execução, no qual foi realizada reunião em agosto de 2020, com metodologia participativa para levantar as demandas prioritárias para 2021, no tocante a organizar as estratégias de apoio à cooperação, bem como de possível renovação para mais quatro anos.

\footnotetext{
${ }^{16}$ A Parceria das Declarações de Amsterdã consiste em sete países europeus comprometidos em eliminar o desflorestamento das cadeias de suprimento agrícolas à Europa: Alemanha (atualmente na presidência), Dinamarca, França, Itália, Holanda, Noruega, Reino Unido.
} 


\section{Regularização fundiária na Amazônia legal}

\section{CONSIDERAÇÕES FINAIS}

Devemos ressaltar que esse panorama, ao qual o Projeto Regulariza Amazônia se debruça, que visa acelerar e modernizar a regularização fundiária, não deve ser deslocado dos interesses da abertura do mercado fundiário de terras públicas a investidores estrangeiros, questão essa em tramitação e discursão no Congresso Nacional prioritariamente

A titulação tem sido vendida pelo governo e comprada por muitos (as) assentados (as) como um grande feito, pois em princípio os agricultores terão a posse de suas terras. Esse discurso tem, contudo, motivações muito perversas que logo serão sentidas por meio das flutuações do preço das terras, do aquecimento do nosso mercado fundiário de terras e das consequências que levarão à expulsão das famílias assentadas - e agora tituladas - por força das pressões de grandes fazendeiros e de imobiliárias rurais pelo projeto de Lei 4.059/2012 ${ }^{17}$, de autoria da Comissão de Agricultura, Pecuária, Abastecimento e Desenvolvimento Rural, que busca, via rigor e arrepio da lei, critérios de aquisição de áreas rurais e suas utilizações, por pessoas físicas e jurídicas estrangeiras.

Segundo Delgado (2016), o mercado de terras do Brasil defende-se da desvalorização mediante um tríplice movimento, que segundo o economista é endógeno à realidade agrária brasileira, porém, na conjuntura da crise cíclica do capital, adquire maior amplitude: 1) mercadorização irrestrita; 2) ultraconcentração; 3 ) internacionalização.

A pesquisa feita pela FNP Consultoria \& Negócios mostra que o preço da terra média no Brasil, a partir de 2012, aumentou $227 \%$. Na referida pesquisa realizada pela equipe de consultores da FNP, constata-se que a mundialização da agricultura brasileira expressa uma nítida relação simbiótica com o marcado de terras, no qual o alto preço das commodities agrícolas, sobretudo a expansão da soja na Amazônia Legal, provocou uma valorização recorde nos preços das terras. "A moeda usada nos negócios não é o real, mas a soja, como nos últimos dois anos os grãos se valorizaram, a propriedade também se valorizou" (portal do agronegócio, 2013, p. 2).

\footnotetext{
17 PL 4059/2012 (Projeto de Lei) Ementa: Regulamenta o art. 190, da Constituição Federal, altera o art. $1^{\circ}$, da Lei 4.131 , de 3 de setembro de 1962 , o art. $1^{\circ}$ da Lei 5.868 , de 12 de dezembro de 1972 e o art. $6^{\circ}$ da Lei 9.393, de 19 de dezembro de 1996 e dá outras providências. Dados complementares: critérios de aquisição de áreas rurais e suas utilizações por pessoas físicas e jurídicas estrangeiras. Disponível em: www.camara.leg. br/proposicoesWeb/fichadetramitacao?idProposicao=548018. Acesso em: 16 set 2021.
} 
O projeto Regulariza Amazonia poderá fomentar, ainda mais, o mercado de terras no Brasil, ao impulsionar a corrida pela acumulação de terras públicas (em escala e volume) a ser consumida pelo mercado global de terra: land global.

Nesta condição, terras de domínio comum em grandes hectares da Amazônia brasileira passam a entram no circuito da troca do capital globalizado, generalizando a sua dimensão como mercadoria. Nesse processo, o valor de troca ganha amplitude enquanto condição da reprodução do capital, em que as terras devolutas e públicas, principalmente da Amazônia legal, assumem o papel de simulacro (imitação, cópia, ruína) espacial de mercado global de terras.

\section{Agradecimentos}

Este texto científico é realizado com apoio e financiamento de bolsa de estudo na modalidade de pós-doutorado júnior (PDJ) do Conselho Nacional de Desenvolvimento Científico e Tecnológico (CNPq, Brasil).

\section{REFERÊNCIAS}

BECKER, Bertha K. Redefinindo a Amazônia: o vetor tecno-ecológico. In. Castro, Iná de; GOMES, Paulo, C. da C; CORRÊA, Roberto, L.(org.) Brasil: questões atuais da reorganização do território. 3. ed. Rio de Janeiro: Bertrand Brasil, 2005, p. 470.

BRASIL. Lei n. 11.952, de 25 de junho de 2009. Dispõe sobre a regularização fundiária das ocupações incidentes em terras situadas em áreas da União, no âmbito da Amazônia Legal. Disponível em: www.planato.gov. brlccivil_03\_2007-2010\2009\Leil11949. Acesso em: 10 ago. de 2021.

BRASIL, Incra. Projeto "Apoio à política de regularização fundiária na Amazônia e nos estados do Amazonas, Pará, Mato Grosso e Amapá”. Termos de referência para consultor de curto prazo (NKE) para execução do plano de comunicação e visibilidade. Brasília, outubro de 2019. Disponível em: www.iieb.org.br/wp-content/uploads/2019/10/TDR-Visibilidade-versa \%CC\% 83o-final-APROVADO-1.pdf. Acesso em: 15 ago. 2021.

BRASIL. Presidência da República. Plano Amazônia Sustentável: diretrizes para o desenvolvimento sustentável da Amazônia Brasileira. Brasília: Ministério do Meio Ambiente, 2008. Disponível em: www.fundoamazo- 


\section{Regularização fundiária na Amazônia legal}

nia.gov.br/export/sites/default/pt/.galleries/documentos/biblioteca/PAS-Presidencia-Republica.pdf Acesso em: 5 ago. 2014.

BRASIL, Serfal. Relatório de Desempenho 2009/2014 e Plano de Metas 014/2019. 2019. Brasília: MDA. Secretaria Extraordinária de Regularização Fundiária na Amazônia Legal - Serfal. p. 34.

BRITO, Brenda B; BARRETO Paulo. A regularização fundiária avançou na Amazônia? Os dois anos do Programa Terra Legal. Belém: Imazon, 2011.

DELGADO, Guilherme. O movimento do mercado de terras. Le Monde Diplomatique. Abril, 2016. Disponível em: www.diplomatique.org.br/o-movimento-do-mercado-de-terras/. Acesso em: 25 ago. 2019.

FAO. Organización de las Naciones Unidas para la Agricultura y la Alimentación. Buena gobernanza en la tenencia y la administración de tierras. Roma, 2007.

MELLO-THÉRY. Neli. Políticas territoriais na Amazônia. São Paulo: Annablume, 2006.

MELLO-THÉRY. Neli. Território e gestão ambiental na Amazônia: terras públicas e os dilemas do estado. São Paulo: Annablume, 2011. p. 220.

PARCERIA DECLARAÇÕES DE AMSTERDÃ. Carta Aberta. Alemanha, 2020. Disponível em: https://ad-partnership.org/wp-content/ uploads/ 2020/09/ADP-Brazil-Open-letter_POR.pdf.

Portal do Agronegócio. Preço da terra agrícola subiu 227\% em dez anos, quase o dobro da inflação. Data de publicação: 05/03/2013. Disponível em: www.portaldoagronegocio.com.br/noticia/preo-da-terra-agrcola-subiu-227-em-dez- anos-quase-o-dobro-da-inflao-9018. Acesso em: 5 ago. 2021.

PORTO-GONÇALVES, W. Amazônia, amazônias. São Paulo: Contexto, 2001. p. 178.

RIBEIRO, Alyson. F. A; COSTA SILVA, Ricardo, G; LISBOA, Josefa, S. Política de regularização fundiária em Rondônia: limitações do programa terra legal e expectativas socioterritoriais, Confins [En ligne], 29 । 2016, mis en ligne le 19 décembre 2016, consulté le 19 décembre 2020. Disponível em: www.journals.openedition.org/confins/11541.

RIBEIRO, A. F. A. A regularização fundiária como (in)solução para a questão agrária: o desvelar do Programa Terra Legal Amazônia no Cone-Sul de Rondônia. 2016. 217 f. Dissertação (mestrado em geografia), Universidade Federal de Rondônia, Porto Velho, 2016. 
RIBEIRO, Alyson. F. A Geografia agrária e modernidade na Amazônia brasileira: "terras esplêndidas, que poderiam dar a todos o que a quase todos negam". Tese (doutorado em geografia), Universidade Federal de Sergipe, 2020.

REYDON, Bastiaan P; FERNANDES, Vitor B; BUENO, Ana Paula S. Governança de terras: da teoria à realidade brasileira. FAO. Organização das Nações Unidas para a Alimentação e a Agricultura. /SEAD: Brasília, 2017. 


\section{PARTE 2}

\section{EXPANSÃO DA FRONTEIRA E COMUNIDADES RURAIS AMAZÔNICAS}




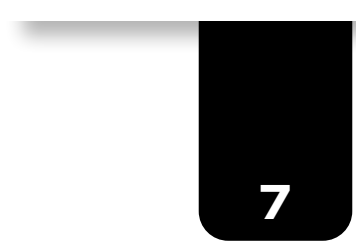

TRANSAMAZÔNICA: NOVA FRONTEIRA DE EXPANSÃO E ÁREAS PROTEGIDAS NO ESTADO DO AMAZONAS ${ }^{18}$

\author{
Ricardo Gilson da Costa Silva" \\ Viviane Vidal da Silva"* \\ Neli Aparecida de Mello-Théry (in memoriam) ${ }^{* * * *}$ \\ Luís Augusto Pereira Lima ${ }^{* n * n}$
}

\title{
INTRODUÇÃO
}

Desde a ditatura militar (1964-1985), a região amazônica tem um papel de destaque no contexto da geopolítica interna do Brasil, sobretudo, considerando os inúmeros desafios estatais para com a gestão do território. Para o estado brasileiro, ainda na atualidade, o propósito é garantir a soberania desta região. Desta forma, o governo militar implementou uma série de políticas territoriais e programas que possibilitou uma nova ocupação humana, circulação e a integração econômica da região Norte ao restante do país.

A política de povoamento, nesse período, a partir dos eixos de circulação, como a rodovia BR-230 ou transamazônica, instaurou um quadro de transformações sociogeográficas alicerçadas nos processos econômicos de incorporação da natureza como capital. No outro polo, os povos originários, as comunidades tradicionais e seus territórios so-

\footnotetext{
${ }_{18}$ Artigo publicado com apoio institucional da Fapeam (Edital 006/2019 Universal Amazonas) e Fapero (Edital 004/2018 PAP/Universal). COSTA SILVA, R. G; SILVA, V. V; MELLO-THÉRY, N. A; LIMA, L. A.P. Nova fronteira de expansão e Áreas Protegidas no estado do Amazonas. Mercator, Fortaleza, v. 20, e20025, p. 1-13, 2021.

" https://orcid.org/0000-0002-3348-9629

** https://orcid.org/0000-0002-0887-7523

*** https://orcid.org/0000-0003-2313-2121

**** https://orcid.org/0000-0003-0390-4315
} 


\section{Transamazônica: nova fronteira de expansão \\ e áreas protegidas no estado do Amazonas}

freram um forte processo de invasão e conflitos que resultaram em massacres, desmatamentos e desterritorializações da população que vivia há séculos na Amazônia, situação que se mantém na atualidade.

As incontestáveis evidências dos impactos ambientais na região, dentre elas, o desmatamento, realçam a espacialidade do processo de expansão da sociedade (migração) e do capital (acumulação) na floresta amazônica. Fortalecidas pelo debate sobre proteção da natureza no início da década de 1990, as políticas territoriais passaram a incorporar a temática ambiental e, assim, foram criados e ampliados os espaços protegidos, como as unidades de conservação, terras indígenas e outros territórios tradicionais de comunidades rurais. Atualmente, a gestão do território tem incorporado questões socioambientais a fim de garantir acesso aos recursos da natureza não somente à população tradicional, mas também aos grandes projetos de extração mineral, energético e biotecnológico. Essas contradições, no âmbito das políticas públicas, são geradoras de inúmeros conflitos territoriais e incertezas para os povos amazônicos (indígenas, seringueiros, extrativistas, quilombolas, pescadores comunitários, comunidades rurais que vivem na floresta, dentre outros).

No contexto atual, assiste-se ao que já foi identificado, em outras áreas da Amazônia, a implementação de duas políticas territoriais contraditórias: as políticas ambientais e as políticas de desenvolvimento econômico. Na rodovia transamazônica, particularmente no estado do Amazonas, afirmam-se as disputas por território, uma verdadeira miríade de conflitos territoriais, aceleradas nos últimos anos em função do crescimento do agronegócio e de expansão da fronteira, conceito entendido como um espaço ainda não plenamente estruturado (Becker, 2004), com possibilidades de reconfigurações de projetos econômico-territoriais, que se desdobra lato sensu na transformação da natureza em espaço da economia extrativa (pecuária, madeira, minério, mercado de terras e hidrelétrica).

No plano metodológico, adotou-se a revisão bibliográfica, análise de documentos e relatórios de instituições públicas, trabalho de campo e cartografia temática para a compreensão do espaço regional. Os trabalhos de campo foram realizados nos municípios de Humaitá e Apuí, e a observação de campo foi realizada ao logo da rodovia transamazônica, ambos ocorreram alternadamente, em 2019 e 2020. Os diálogos intersubjetivos foram feitos com moradores, comerciantes e assentados com o objetivo de compreender os processos que configuram a expansão da 


\section{Geografia, território e sociedade na Amazônia}

fronteira, principalmente no distrito de Santo Antônio do Matupi (Manicoré) e Vila de Realidade (Humaitá).

$\mathrm{Na}$ produção cartográfica, a metodologia utilizada adicionou os dados dos trabalhos de campo, consultas da base de dados da Infraestrutura Nacional de Dados Espaciais (INDE), cuja plataforma oferece uma gama de dados relacionados à Amazônia. Dentre essas consultas, foram examinados e obtidos dados relativos ao Incra, Ministério dos Transportes, ANA, IBGE, ICMBio e SEMA (AM). Nesse percurso, utilizou-se o software SIG (sistema de informações geográficas) ArcGIS 10.5 para a elaboração dos mapas. Tal software dispõe de aplicações que permitem utilizar ferramentas para edição de dados vetoriais e seleção por atributos dos arquivos em formato shp (shapefile), cujas finalidades nos permitiram indicar a relação de assentamentos, vilas, comunidades e cidades, unidades de conservação, terras indígenas e rodovias.

O artigo está organizado a partir da análise da ação do Estado, destacando a função dos eixos rodoviários como elos que articulam espacialmente a região aos demais fluxos econômicos do Brasil. Trata-se de pensar a configuração da Amazônia Legal a partir das estradas, processo que transformou estruturalmente o espaço regional e que ainda constitui em frentes de expansão econômica nas diversas sub-regiões amazônicas. Posteriormente, a análise versa sobre as políticas ambientais (unidades de conservação e terras indígenas) ao longo da rodovia transamazônica, priorizando o município de Apuí. Em seguida, problematiza-se o revigoramento da fronteira na transamazônica com base na expansão pecuária, desmatamento e projetos minerais e hidrelétricos.

RODOVIA TRANSAMAZÔNICA E A CONFIGURAÇÃO TERRITORIAL DO SUL Do Amazonas

Antes de analisar a situação da rodovia transamazônica, considera-se importante elencar alguns argumentos utilizados por estudiosos. Uma das recorrentes visões externas à Amazônia é a de sempre constituir fonte de recursos naturais abundantes, processo que por décadas vem lhe qualificando como fronteira econômica (Becker, 1983). Sua expansão espacial encontra-se relacionada às diferentes políticas públicas territoriais que redirecionaram os fluxos econômicos e demográficos para a Amazônia. Nessa ótica, a referência de exploração da natureza foi uma constante simbólica que "atraiu" à região: capitais para a agropecuária, mineração e exploração madeireira, mercado de terras e energia elétrica. 


\section{Transamazônica: nova fronteira de expansão \\ e áreas protegidas no estado do Amazonas}

Atualmente, esse processo continua e se direciona especialmente para algumas sub-regiões que, até então, estavam localizadas fora do eixo das dinâmicas predominantes, como é a situação da região da rodovia transamazônica, no sul do estado do Amazonas.

O estado brasileiro, como um agente territorial, implementou uma agenda estratégica com políticas territoriais que reconfiguraram a Amazônia brasileira, sendo fator de atração dos fluxos de capitais na economia extrativa, somado à migração populacional para os variados projetos de colonização pública e privada nos estados do Pará, Mato Grosso e Rondônia (Becker, 2004; Mello, 2011; Costa Silva, 2017). As políticas territoriais têm a função de modelar o espaço, produzir e organizá-lo como objeto de intervenção pública, designando-o como condição para outras espacializações, o que tende a resultar em lógicas de reestruturação e adequação do território e dos lugares atingidos (Mello-Théry, 2006). De modo geral, as dinâmicas territoriais na Amazônia refletem às diferentes políticas territoriais implementadas pelos governos que priorizaram, em distintos períodos, a integração, o desenvolvimento e a conservação de seus recursos naturais, ainda que por um tempo curto (Loureiro, 2009).

Certamente, o expressivo apoio estatal, tanto no planejamento quanto na construção de estradas, abriu um conjunto de possibilidades socioeconômicas que qualificou a fronteira amazônica como um novo espaço de acumulação do capital. A complexidade dos contextos históricos resultou de distintas motivações, de modo que os atores estimularam diferentes processos nessa fronteira, o que implicou em desafios de ordenamento territorial. Fazer a gestão territorial (Becker; Egler, 1997, Mello-Théry, 2006; Gelpi; Kalil, 2015) no campo ou na cidade é um processo extremamente complexo, em especial quando tanto as dinâmicas como as políticas territoriais são contraditórias e desarticuladas. Atualmente, existem instrumentos legais criados para poder efetuar tal gestão, como os planos de manejo e os conselhos gestores. No período militar predominaram os planos nacionais e regionais de desenvolvimento (I e II PND, plano de desenvolvimento da Amazônia) e, de certa forma, alguma articulação quanto ao modelo de desenvolvimento adotado. Esse processo criou áreas mais dinâmicas onde se instalaram programas e projetos específicos decorrentes dos planos em oposição às áreas sem incentivo dos governos que estagnaram. Após 1988, com o processo de redemocratização no país e o pacto federativo, houve, simultaneamente, desvalorização das políticas e planos nacionais, transformando os planos plurianuais (PPAs) em simples programação orçamentária, sem 
diretrizes e estratégias mais amplas. Assim, a gestão termina por atuar mais localmente, que regionalmente.

Em termos de articulação espacial, destacam-se as estradas e rodovias como elos do sistema territorial de gestão política e estratégica do Estado, na Amazônia. A integração territorial (Mapa 1) se configurou com a construção da BR-230 (transamazônica), BR-174 (Manaus-Boa Vista), BR-210 (Perimetral Norte) e BR-163 (Cuiabá-Santarém), além da rodovia BR-010 (Belém-Brasília). Essas rodovias materializam um tempo-espaço acelerado na hileia, o tempo da ação do Estado e do capital na reconfiguração da floresta em espaço da agropecuária, de vilas e cidades, dos polos minerais e madeireiros que assimilam a modernidade em contraposição à natureza. Portanto, as rodovias servem como caminhos da marcha da modernização do capital no universo florestal.

Mapa 1 - Principais rodovias no Amazônia Legal (2019).

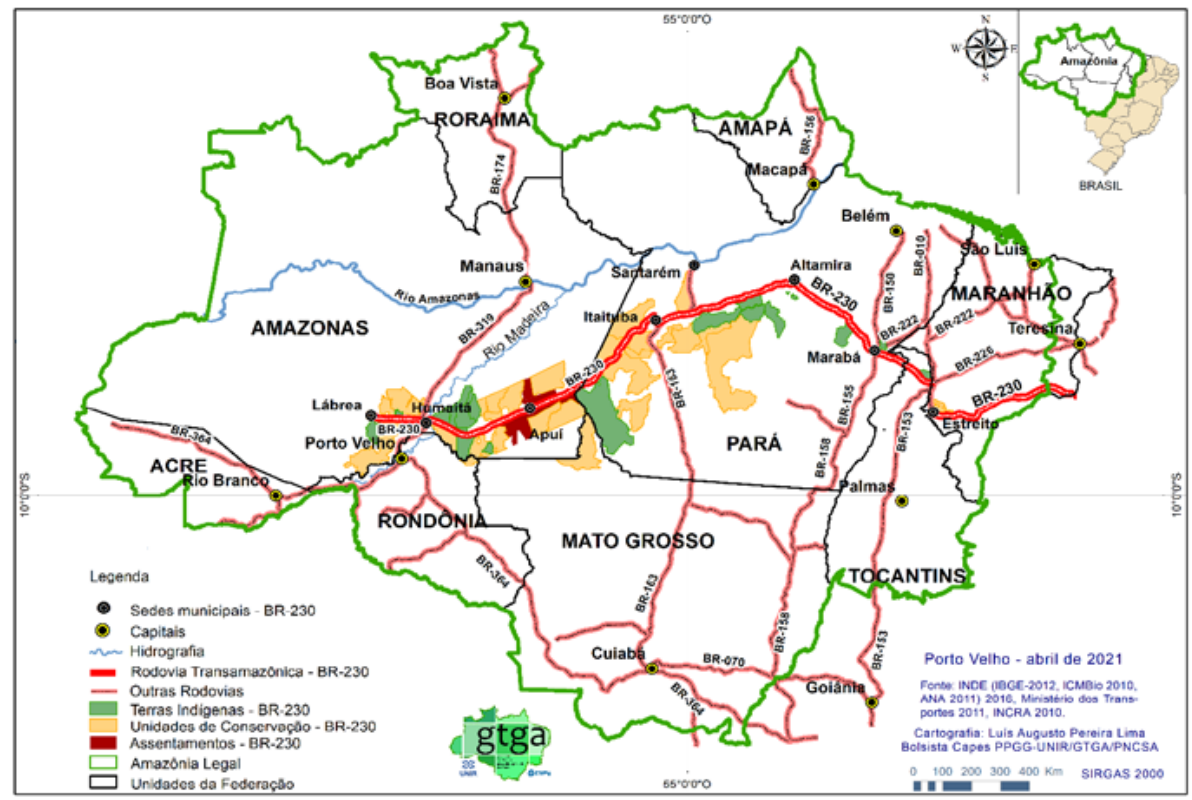

Fonte: GTGA/UNIR.

Com a estratégia de colonização, a justificativa, apoiada na divulgação de problemas relacionados à seca no Nordeste, com investimentos governamentais e empréstimos do Fundo Monetário Internacional (FMI) 


\section{Transamazônica: nova fronteira de expansão \\ e áreas protegidas no estado do Amazonas}

e do Banco Internacional para a Reconstrução e Desenvolvimento (BIRD) (Oliveira Neto, 2015), predominou a construção das rodovias no sentido (Norte-Sul), à exceção da transamazônica, no sentido transversal (Leste-Oeste), do município de Cabelo (Paraíba) até Lábrea (Amazonas), representando um dos elementos mais importantes do I PND (1972-1974).

$\mathrm{O}$ objetivo foi favorecer acesso às áreas com possibilidade de exploração produtiva e de solos mais favoráveis à implantação da agropecuária, além de privilegiar as relações da Amazônia com as demais regiões brasileiras, principalmente para com o fluxo demográfico do nordeste do Pará, e sul e sudeste do Mato Grosso e Rondônia, potencializando, assim, o fortalecimento do comércio inter-regional (Becker, 2004; Costa Silva, 2005; Huertas, 2009; Mesquita, 2011).

Associado à implementação dos eixos de circulação, por meio do Decreto Lei n. 1.164, de $1^{\circ}$ de abril de 1971, foram destinados $100 \mathrm{~km}$ de terras às margens das rodovias implementadas para que o governo militar realizasse o processo de ocupação e colonização da região, além de projetos agroindustriais (Becker, 1983; Loureiro, 2009, Mello-Théry, 2011). Especialmente na rodovia transamazônica, o Instituto Nacional de Colonização e Reforma Agrária (Incra) criou o Projeto de Assentamento (PA) Rio Juma, em 1982, dando origem, em 1987, ao município de Apuí, sul do estado do Amazonas (Mapa 1). Apoiado no Projeto de Integração Nacional e sob o slogan "uma terra sem homens para homens sem-terra", o governo promoveu a migração de colonos para ocupar a região. Diferentemente do modelo baseado no extrativismo das populações tradicionais da Amazônia e dos atuais projetos de assentamentos extrativistas e de desenvolvimento sustentável, consolidou-se outro modelo, este agora fundamentado na derrubada da floresta, desmatamento e extração madeireira para implantação da agropecuária.

Os eixos principais de circulação, de certa maneira, reorganizam as formas de vida coletiva na região, passando das margens dos rios, da produção e do cotidiano ribeirinho às margens das estradas, novo modo de vida do migrante (Loureiro, 2009). Os projetos de colonização agrícola fizeram parte de uma política territorial estratégica, inclusive como uma alternativa conservadora à reforma agrária exigida pelos movimentos sociais do campo, pari passu à expansão de áreas agrícolas, processo que configurou a Amazônia como reserva territorial de reprodução do capital (Costa silva, 2017; Mesquita, 2011).

As estratégias das políticas territoriais dos planos de desenvolvimento privilegiaram a colonização agrícola, construção de rodovias 


\section{Geografia, território e sociedade na Amazônia}

e projetos agropecuários e de mineração, produzindo intensas transformações na região amazônica e provocando, ao final da década de 1980, preocupações com a proteção ambiental.

Nesses contextos, as rodovias se tornaram os eixos da expansão econômica que incorporaram a natureza no circuito mercantil, alimentando os fluxos na fronteira. Esse processo também se realiza no âmbito do crime ambiental e nas pressões e invasões de áreas públicas, inclusive nas áreas públicas já destinadas. Tal situação se verifica no sul do estado do Amazonas, principalmente no PA Rio Juma, que possui uma área de 689.000,00 hectares, com 6.000 famílias assentadas, e apesar dos 39 anos de criação, ainda está em fase de consolidação (Incra, 2021).

$\mathrm{O}$ assentamento ainda apresenta problemas de regularização fundiária incompleta, uma vez que somente $17,6 \%$ de sua área está titulada. Soma-se um alto processo de evasão e concentração fundiária, com "proprietários" e propriedades com até 15 lotes no PA Rio Juma. Mais de $50 \%$ da área do PA Juma encontra-se ilegalmente ocupada por fazendeiros que buscam, por meio das atuais políticas territoriais, como o programa Terra Legal, a regularização fundiária (Menezes, 2015) facilitada pelas instruções normativas 98 e 99/2019 do Incra, relacionadas aos procedimentos simplificados para a titulação de imóveis rurais. Nesse contexto, a dinâmica de uso e ocupação da terra no Apuí tem passado da colonização com assentamentos rurais para a expansão do agronegócio, impulsionado, sobretudo, pela descaraterização do PA Juma, com ampliação do desmatamento e mercado de terras (Galuch; Menezes, 2019).

Somado à pecuária e ao desmatamento, particularmente na BR230 (rodovia transamazônica), há toda uma movimentação espacial do capital a partir de projetos agropecuários, minerais, madeireiros e energéticos que atingem direta e indiretamente as áreas protegidas institucionalizadas pelo Estado, produzindo conflitos na expansão da fronteira que adentra o sul do estado do Amazonas (Costa Silva; Silva; Lima, 2019).

\section{As ÁREAS PROTEGIDAS NA RODOVIA TRANSAMAZÔNICA}

A partir da década de 1990, com a emergência das questões e dos discursos ambientais, as políticas territoriais foram qualificadas por programas orientados à conservação das florestas tropicais como, por exemplo, o Programa Nossa Natureza (1988) e o Programa Internacional Piloto para a Conservação das Florestas Tropicais Brasileiras 


\section{Transamazônica: nova fronteira de expansão \\ e áreas protegidas no estado do Amazonas}

(PPG-7). Na esfera do Programa Nossa Natureza, o debate sobre o ordenamento territorial e o instrumento do zoneamento ambiental se ampliaram e passaram a ser a base do moderno mecanismo de proteção ambiental e de gestão do território, embora muito questionada pelos estados amazônicos.

A Política Nacional de Meio Ambiente (PNMA, Lei 6.938 de 31/08/1981) definiu, entre os diversos instrumentos para a conservação da natureza, o zoneamento ambiental. A nomenclatura atual passou a ser Zoneamento Ecológico-Econômico (ZEE) e foi instituído pelo Decreto 7.378 , de $1^{\circ}$ de dezembro de 2010. Mesmo com a implementação das políticas ambientais e a instrumentalização do ZEE, as macropolíticas do governo brasileiro continuaram a priorizar a Amazônia como estratégia para integrar áreas do Brasil e da América Latina, haja vista que o Programa Brasil em Ação (1996-1999) e em seguida o Programa Avança Brasil (2000-2003) apresentaram os Eixos Nacionais de Integração e Desenvolvimento (ENIDs) como referência de ordenamento regional no Brasil, baseado em integração logística de regiões produtivas. Posteriormente, o Plano Amazônia Sustentável (PAS), reelaborado em 2008 no governo Lula, mesmo mantendo as políticas territoriais anteriores, convergiu para o modelo de desenvolvimento sustentável no combate aos processos de degradação ambiental, estabelecendo diretrizes para o ordenamento territorial e gestão ambiental, além de integrar políticas de ordenamento territorial com ações de desenvolvimento sustentável (Mello; Pasquis; Théry, 2004; Brasil, 2008). 
Mapa 2 - Transamazônica e o Macrozoneamento Ecológico-Econômico da Amazônia Legal (2020).

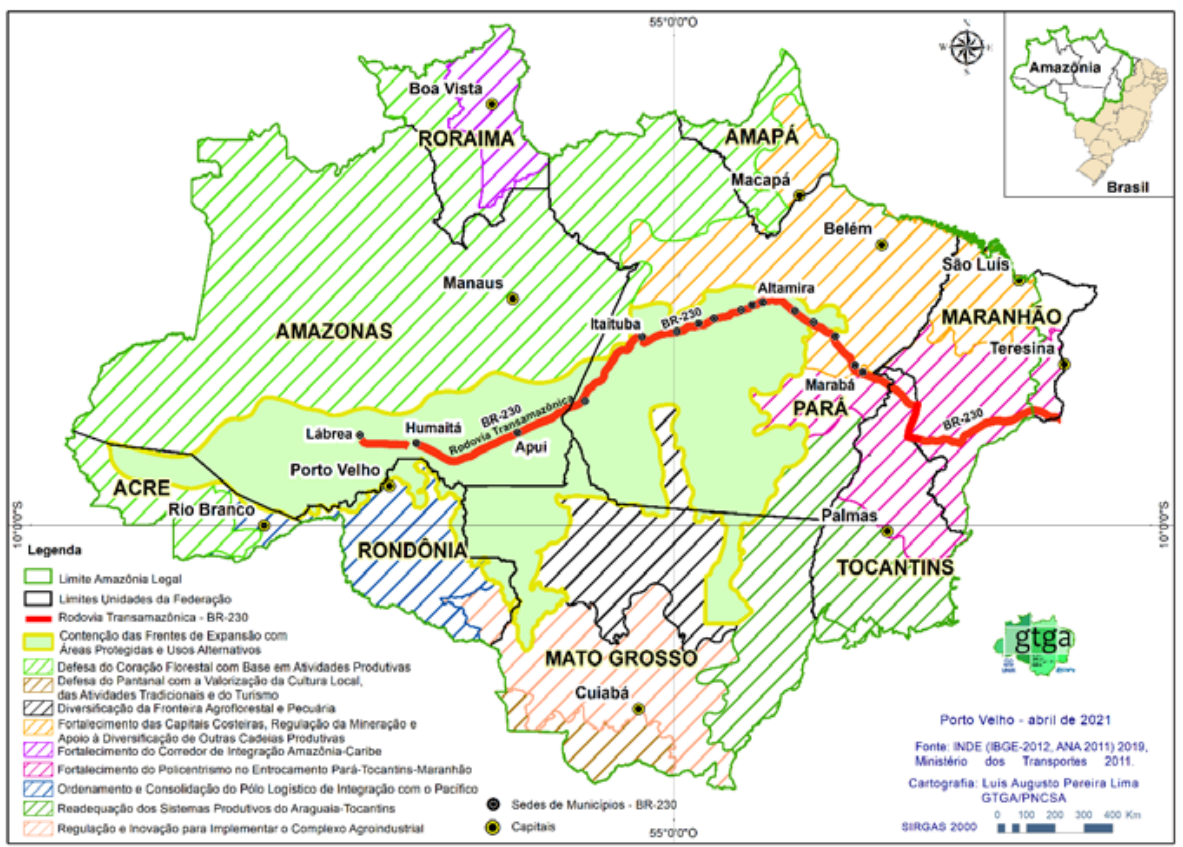

Fonte: GTGA/UNIR, com base nas informações de: IBGE; ANA; Ministério dos Transportes.

Com o Decreto 7.378 , de $1^{\circ}$ de dezembro 2010, o Macrozoneamento Ecológico-Econômico da Amazônia Legal - MacroZEE ${ }^{19}$ (Mapa 2), cujo objetivo é garantir a sustentabilidade do desenvolvimento regional, indicando estratégias produtivas e de gestão ambiental e territorial em consonância com a diversidade ecológica, econômica, cultural e social da Amazônia, também se articula com os ZEEs dos estados da Amazônia Legal, o que, de certa forma, se constituiu numa política de gestão do território com todos os entes federativos envolvidos. Busca um processo mais articulado na elaboração das políticas nacionais, considerando-se as recomendações de uso para cada macrozona.

\footnotetext{
${ }^{19}$ A discussão sobre o Zoneamento e MacroZEE da Amazônia remonta o ano de 1990, quando o IBGE foi contratado para realizá-lo. Muitas polêmicas e conflitos sobre metodologias, recursos, atribuições da União ou dos Estados federados surgiram ao longo das duas décadas seguintes até, finalmente, em 2010, conseguirem aprová-lo.
} 


\section{Transamazônica: nova fronteira de expansão \\ e áreas protegidas no estado do Amazonas}

O MacroZEE instituiu três unidades territoriais como mecanismos de ordenamento territorial: territórios-redes, territórios-fronteiras e territórios-zona ${ }^{20}$. Na macroescala, o município de Apuí, assim como todos os municípios do sul do Amazonas encontram-se no território-fronteira. Nesse território, o MacroZEE identifica duas gradações da fronteira: a diversificação da fronteira agroflorestal e pecuária e a contenção das frentes com áreas protegidas e usos alternativos (Brasil, 2010). Essa é a gradação da fronteira que se identifica no município de Apuí, ao longo da BR-230, que se efetiva com desmatamento, comércio ilegal de terras públicas (grilagem); aquecido com a pecuária, sobretudo no assentamento Rio Juma. Por outro lado, no âmbito das políticas ambientais, tem-se o conjunto de unidades de conservação, o Mosaico do Apuí, a Floresta Nacional do Jatuarana e parte do Parque Nacional do Juruena, que compreendem 63,31\% do município de Apuí, que forma um conjunto territorial para conter o desmatamento e possibilitar usos biotecnológicos e sustentáveis pelas comunidades tradicionais.

Contudo, diante do revigoramento da fronteira que se expande na Amazônia e da inserção do Brasil no processo de globalização (produção de commodities), o que se observa no município de Apuí é a expansão do capital se materializando no aumento dos efetivos bovinos, expansão energética e mineral associados à clássica grilagem de terras públicas. Desta forma, como afirma Madeira (2014), no MacroZEE, o território-fronteira representa, praticamente, continuidades de grandes projetos iniciados na década de 1980 e que, atualmente, estão vinculados ao eixo de integração Madeira-Amazonas, componente dos ENIDS, e à expansão das commodities na região (Costa Silva; Conceição, 2017; Mesquita, 2009).

\footnotetext{
${ }^{20} \mathrm{O}$ MacroZEE instituiu dez unidades territoriais distribuídas entre as categorias território-rede, território-fronteira e território-zona. O território-rede corresponde as áreas de povoamento consolidado, caracterizado por dominância de redes e engloba as seguintes unidades territoriais: o corredor de integração Amazônia-Caribe, as capitais costeiras, a mineração e outras cadeias produtivas, o entroncamento Pará-Tocantins-Maranhão, o eixo Araguaia-Tocantins, o complexo agroindustrial e o polo logístico. Os território-zona correspondem as áreas de floresta ombrófila densa e outras formações vegetais contínuas e com baixo grau de antropismo e abrangem as unidades territoriais defesa do coração florestal com base em atividades produtivas e defesa do Pantanal com a valorização da cultura local, das atividades tradicionais e do turismo. Por fim, os território-fronteira apresentam diferentes estágios de apropriação da terra, do povoamento e de organização e constituem as franjas de penetração e compreendem as unidades territoriais da diversificação da fronteira agroflorestal e pecuária e a contenção das frentes com Áreas Protegidas e usos alternativos (BRASIL, 2010).
} 


\section{Geografia, território e sociedade na Amazônia}

No estado do Amazonas, com a descentralização das políticas ambientais, processo esse que iniciou no governo de Amazonino Mendes (1999-2003) como forma de modernizar a gestão, e ganhou relevância no governo de Eduardo Braga (2003-2007). Por meio de uma agenda socioambiental, o governo estadual se aproximou de grupos que estavam à margem do processo político, a exemplo das comunidades tradicionais amazônicas territorializadas nas diversas sub-regiões amazonenses (Villarroel; Toni, 2012). Com a implementação do Programa Zona Franca Verde, durante o primeiro mandato de Eduardo Braga (2003-2007), o governo do estado passou a adotar uma política de uso sustentável dos recursos naturais, compromisso estatal com a qualidade de vida da população do interior e com a proteção do patrimônio natural do Amazonas, ressaltando que esse programa tinha como um dos principais eixos a criação de Unidades de Conservação (Santos, 2013).

Acompanhando o contexto de inserção da conservação dos recursos na gestão territorial e a determinação da realização do ZEE pelos estados da Amazônia Legal, o macrozoneamento do estado do Amazonas foi instituído pela Lei 3.417, de 31 de julho de 2009. Seguindo o MacroZEE, os municípios da fronteira sul do Amazonas configuram-se como áreas de estrutura produtiva definida, áreas de unidades de conservação e terras indígenas instituídas e áreas potenciais para a criação de unidades de conservação.

$\mathrm{Na}$ região sul do Amazonas, as unidades de conservação compreendem um total de 32 unidades, 08 de uso integral e 24 de uso sustentável (Mapa 3), sob a gestão dos governos federal e estadual. Esse conjunto espacial se encontra em situação de conflitos e pressão territorial do capital agropecuário, energético e mineral que alimentam a expansão da fronteira, ainda que evidencie a relevância e a estratégia da proteção ambiental e de defesa dos territórios tradicionais dos povos amazônicos. No contexto amazônico, a criação de áreas protegidas e territórios tradicionais também é resultado dos movimentos de luta de ribeirinhos, pescadores, seringueiros, quilombolas e indígenas que tem garantido o processo de produção do espaço e de territorializações dessas comunidades, constituindo o que Costa Silva e Conceição (2017) denominaram de territórios camponeses/comunidades frente ao território do agronegócio.

Seguindo essa política, o governo estadual instituiu, em 2005, o Mosaico de Unidades do Apuí (Mapa 3), sob a gestão do Departamento de Mudanças Climáticas e Gestão de Unidades de Conservação da Secretaria Estadual de Meio Ambiente do estado do Amazonas. O Mosaico do Apuí compreende 9 unidades de conservação, 2 de proteção integral e 7 de uso sustentável nos municípios de Apuí e Novo Aripuanã, com o 


\section{Transamazônica: nova fronteira de expansão e áreas protegidas no estado do Amazonas}

objetivo de frear o desmatamento que avança do estado de Mato Grosso para a fronteira agrícola no Amazonas.

Mapa 3 - Localização do Mosaico do Apuí com indicação das comunidades rurais (2019).

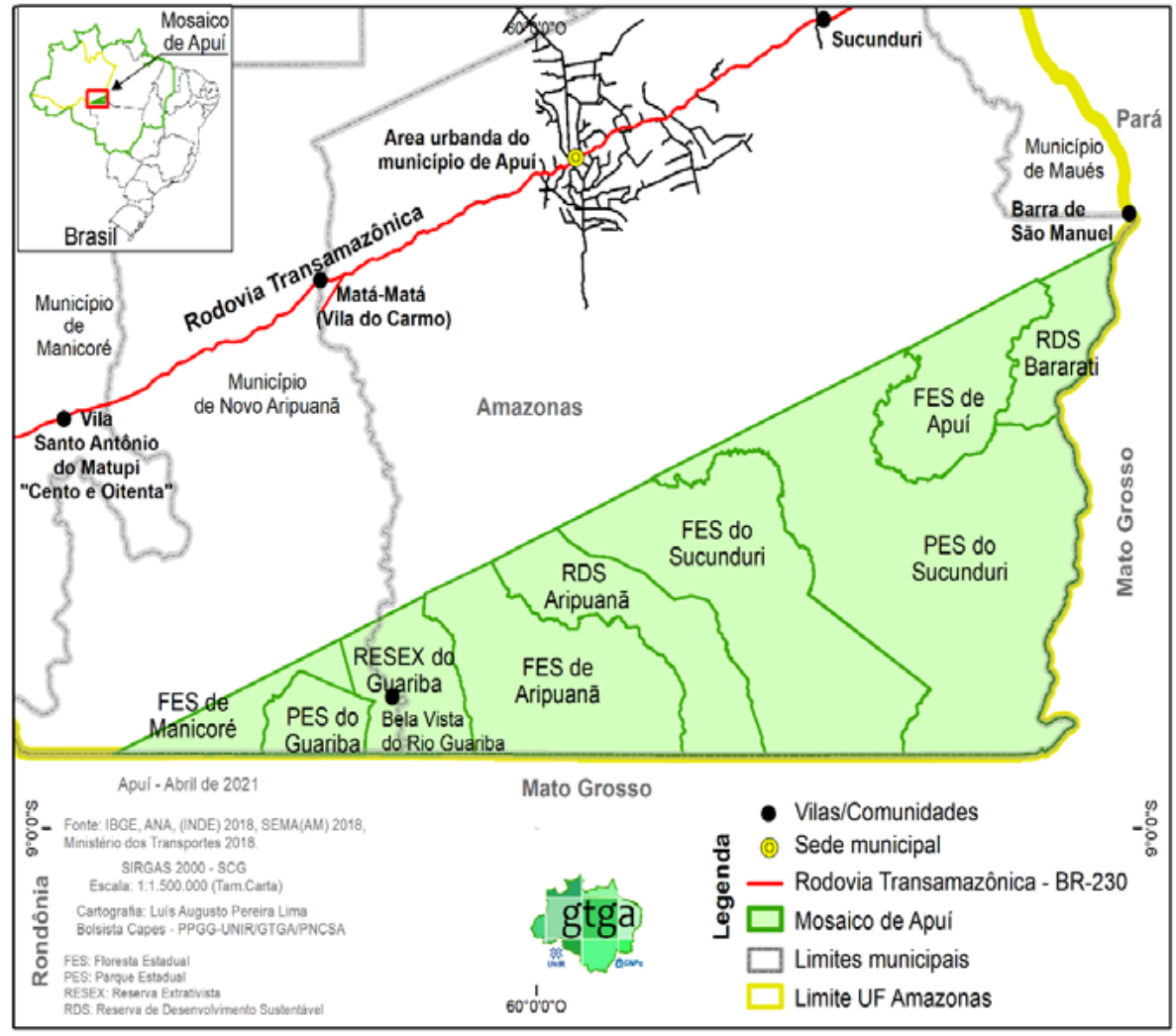

Fonte: GTGA/UNIR, com base em informações de: IBGE, ANA, SEMA e Ministério dos Transportes.

A criação do Mosaico do Apuí resulta de duas políticas públicas para a proteção da Amazônia. Uma dessas políticas foi a implementação do Programa Zona Franca Verde, do governo do estado do Amazonas, que tinha como foco a criação de unidades de conservação. Por sua vez, o Governo Federal criou, por meio do Decreto 4.326, de 8 de agosto de 2002, o Programa de Áreas Protegidas da Amazônia (ARPA), cujo objetivo consistiu na criação e implementação de 60 milhões de hectares de 
áreas protegidas na Amazônia Legal. Segundo o Plano Gestor da Unidade (2010), não existem comunidades tradicionais residentes nas unidades de uso sustentável, mas sete (07) comunidades do entorno realizam atividades extrativistas de óleo de copaíba, látex de seringa e coleta de castanha, na Reserva Extrativista (Resex) do Guariba, na Reserva do Desenvolvimento Sustentável (RDS) do Aripuanã, na RDS Bararati e na Floresta Estadual (Forest) de Apuí. No estado do Amazonas localizam-se as comunidades de Barra de São Manuel, Distrito de Sucunduri, Bela Vista do Rio Gauriba, Matá-Matá (ou Vila do Carmo) e Vila Batista, e em Mato Grosso, as comunidades de Vila Guariba e Vila Colares.

O Mosaico do Apuí tem cumprido um dos seus objetivos, que é frear o desmatamento que se desloca do estado do Mato Grosso para o sul do Amazonas. Ainda que exista financiamento para atividades de fiscalização e para projetos de desenvolvimento sustentável para as comunidades tradicionais, através do programa ARPA, o desafio é monitorar as unidades de conservação que compõem o mosaico. Como consequência, o mosaico enfrenta, continuamente, pressões como a grilagem de terra, invasões pontuais, regularização fundiária e garimpagem.

\section{O REVIGORAMENTO DA FRONTEIRA NA TRANSAMAZÔNICA}

Os projetos econômicos que estão em disputa na Amazônia Ocidental, especialmente ao longo da rodovia transamazônica, são os mesmos que caracterizaram a fronteira econômica classificada pela literatura especializada na região: mineração, hidrelétrica, mercados de terras, grilagem de terras públicas, extração ilegal de madeira, pecuária e, recentemente, agronegócio da soja (Silva; Costa Silva; Lima, 2019). 


\section{Transamazônica: nova fronteira de expansão e áreas protegidas no estado do Amazonas}

Figura 1 - Trecho da rodovia transamazônica - BR-230, sul do Amazonas.

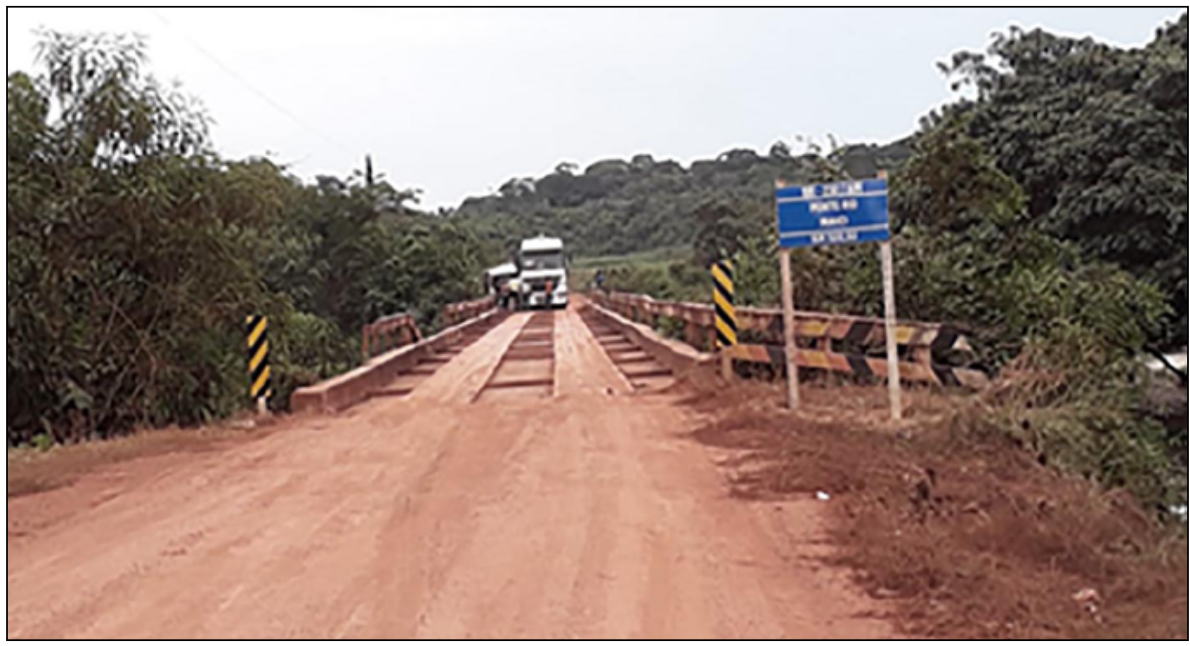

Fonte: Araújo, 2017.

A transamazônica (Figura 1), que possibilitou a chegada dos migrantes para a colonização do Projeto de Assentamento Rio Juma, ainda hoje é o eixo que impulsiona a dinâmica socioeconômica no sul do estado do Amazonas. A "disponibilidade" de áreas públicas e o baixo preço da terra possibilita o crescimento da pecuária extensiva, que tende a substituir a agricultura, uma vez que a rentabilidade bovina se associa à exploração madeireira, garimpo, comércio, e, principalmente, à grilagem de terras públicas (Castro, 2005). Tal processo tem sido incentivado pelo atual Governo Federal, sustentado especialmente pela instrução normativa n. 100/2019 do Ministério da Agricultura, Pecuária e Abastecimento (MAPA), que trata da regularização fundiária de áreas com até 2500 hectares, facilitada pela utilização declaratória do Cadastro Ambiental Rural como comprovação de posse, o que tende a agravar e impulsionar ocupações irregulares na região.

A extração madeireira, comumente, é a primeira atividade que ocorre na fronteira e está organizada sob um sistema complexo, desde processos tradicionais, com o uso de motosserras, até processos industriais (carvoarias, mineração) de beneficiamento legal ou ilegal (Castro, 2005). Essa atividade está associada ao aumento do desmatamento e às pressões nas áreas protegidas, uma vez que os estoques de madeiras com valor no mercado estão localizados em unidades de conservação e terras 
indígenas. Isso significa que tal economia se desenvolve no âmbito do crime ambiental e nos processos de grilagens de terras públicas, donde a pilhagem da natureza tem sido um instrumento recorrente de acumulação do capital (Apublica, 2019).

Mapa 4 - Configuração territorial do município de Apuí (2019).

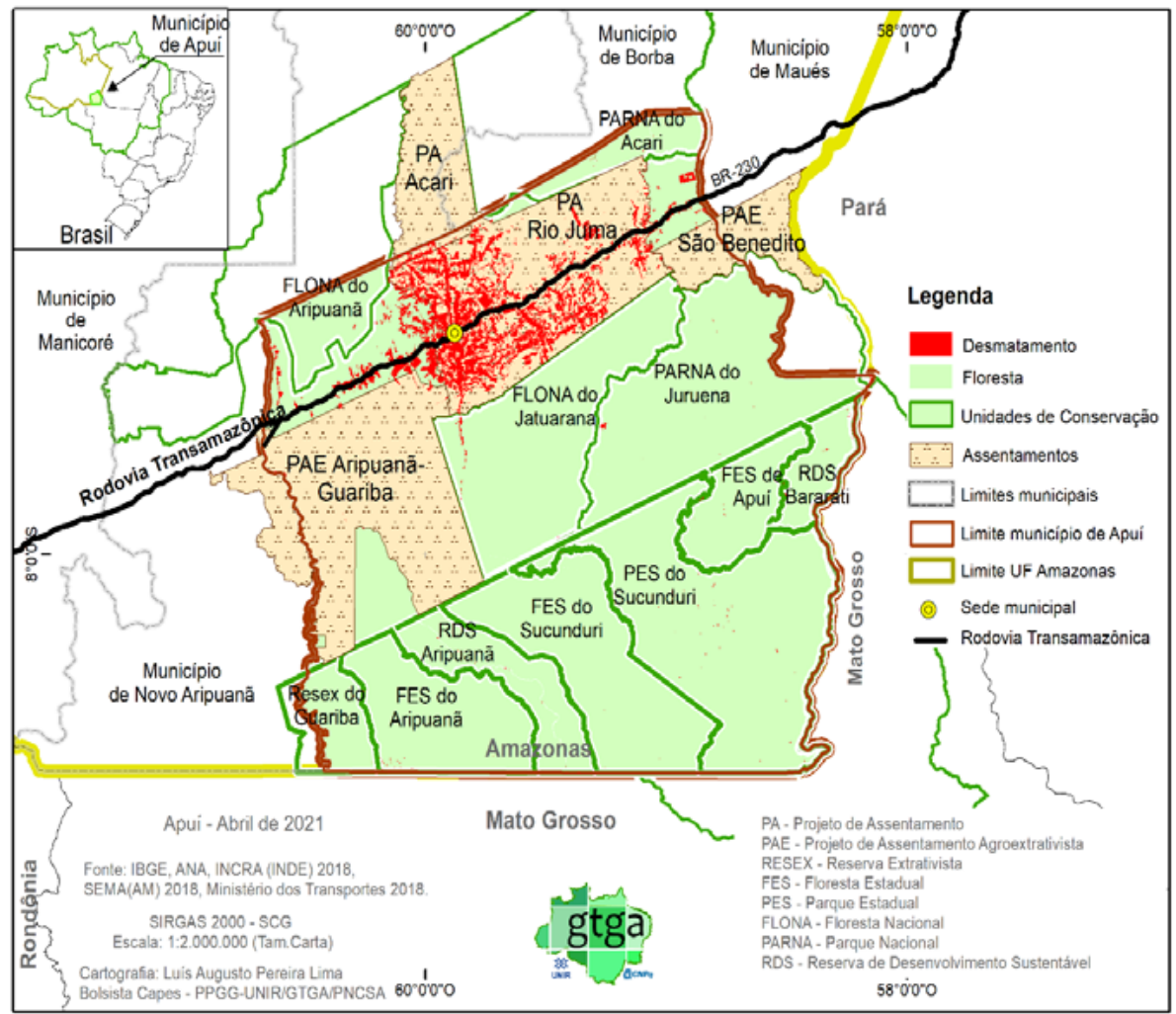

Fonte: INPE, 2019. Elaboração: GTGA/UNIR.

Nessa geografia, o município de Apuí tem ocupado posição de destaque, tanto no número de rebanho bovino, quanto no desmatamento da fronteira. Soma-se a esse contexto o discurso do atual Governo Federal, alinhado a uma perspectiva de (des)amazonização da região, verificada na programada erosão das políticas ambientais, monitoramento e fiscalização, que resultou para Apuí, somente no período de janeiro a julho de 2019, a posição de primeiro entre os 10 municípios com maior 


\section{Transamazônica: nova fronteira de expansão e áreas protegidas no estado do Amazonas}

número de focos de calor (1.754 registros) e área desmatada $\left(151,0 \mathrm{~km}^{2}\right)$ da Amazônia, com o acumulado de desflorestamento de $287,58 \mathrm{~km}^{2}$ no ano de 2019 (Ipam, 2019; INPE, 2019), sobretudo no PA Rio Juma e ao longo da BR-230 (Mapa 4).

Outro elemento que vem ganhando expressão na fronteira do sul do estado do Amazonas é a disputa pelo subsolo, por meio da exploração e prospecção de diversos minérios. No município de Apuí, segundo dados do Sistema de Informações Geográficas da Mineração (SIGMINE) do Departamento Nacional de Produção Mineral (DNPM) ${ }^{21}$, existem solicitações de 209 áreas para pesquisa e exploração, sendo que 49 áreas estão em diferentes fases de processo (Quadro 1), localizadas nas florestas estaduais do Sucunduri do Apuí, de Aripuanã, de Manicoré e na Reserva de Desenvolvimento Sustentável Aripuanã, ambas unidades de conservação de usos sustentáveis que compõem o Mosaico do Apuí.

Quadro 1 - Solicitações de exploração mineral no Mosaico do Apuí (2019).

\begin{tabular}{|l|c|c|c|l|}
\hline \multicolumn{5}{|c|}{ Fases do Processo } \\
\hline Minério & $\begin{array}{c}\text { Requerimento } \\
\text { de pesquisa }\end{array}$ & $\begin{array}{c}\text { Autorização } \\
\text { de pesquisa }\end{array}$ & $\begin{array}{c}\text { Requerimento de } \\
\text { lavra garimpeira }\end{array}$ & \multicolumn{1}{c|}{ Uso } \\
\hline Cassiterita & 3 & & 4 & Industrial \\
\hline Diamante & 13 & & 3 & Gema/Industrial \\
\hline $\begin{array}{l}\text { Minério } \\
\text { de Cobre }\end{array}$ & 1 & & & \\
\hline $\begin{array}{l}\text { Minério } \\
\text { de Estanho }\end{array}$ & & & & Industrial \\
\hline $\begin{array}{l}\text { Minério } \\
\text { de Ouro }\end{array}$ & 3 & & & Industrial \\
\hline $\begin{array}{l}\text { Minério } \\
\text { de Tântalo }\end{array}$ & & & & Metalúrgica/ \\
\hline $\begin{array}{l}\text { Terras } \\
\text { Raras }\end{array}$ & & & & Industrial \\
\hline Wolframita & & & & Industrial \\
\hline
\end{tabular}

Fonte: Adaptado do DNPM, 2019.

${ }^{21}$ Dados acessados no Sistema de Informação Geográfica da Mineração (SIGMINE). Disponível em: www.sigmine.dnpm.gov.br/webmap/. 


\section{Geografia, território e sociedade na Amazônia}

A exploração mineral em unidades de conservação de uso sustentável é apenas proibida nas Resex, segundo o parágrafo $6^{\circ}$, do artigo 18, do Sistema Nacional de Unidades de Conservação (SNUC). No que se refere às florestas estaduais, segundo o Sistema Estadual de Unidades de Conservação do Amazonas (Lei Complementar 53, de 5 de junho de 2007), a exploração mineral depende de autorização ou concessão da União, e ainda, das normas estabelecidas pelo Conselho Estadual de Meio Ambiente do Amazonas. No entanto, para obtenção do direito à exploração mineral, devem ser realizados Estudos de Impacto Ambiental e Relatório de Impacto Ambiental (EIA-RIMA), além de uma forma sustentável no desenvolvimento da atividade. De todo modo, há uma clara “corrida" pelo subsolo, uma disputa pela mercantilização da natureza, convertendo em espaço do capital, ainda que sejam áreas protegidas.

Em outro campo de disputa estão os projetos para a produção de energia, também evidenciados na fronteira do sul do estado do Amazonas. Tais projetos foram denominados por Lima e Costa Silva (2018) como hidroestratégias, ou seja, ações do Estado associadas ao capital industrial que projetam a Amazônia como um espaço de acumulação e intensa mercantilização dos recursos hídricos. Estão planejadas e em execução, no interior ou nos limites de unidades de conservação, pequenas centrais hidrelétricas e usinas nos rios Roosevelt e Aripuanã, gerando tensões e pressões político-territoriais para flexibilizar ou converter áreas naturais em territórios do capital e disputas por territórios pelos diferentes agentes, ou seja, Estado, capital, movimentos sociais e comunidades tradicionais. Ambos os setores têm se beneficiado da flexibilização do processo de licenciamento, o que certamente, contribuirá para o aumento da corrida identificada localmente.

Esses processos qualificam os limites da expansão da fronteira e encontram bases nas mudanças das políticas de gestão ambiental e territorial, a exemplo das alterações do Código Florestal (2012), alterações no Código de Mineração (2018), alterações no Projeto Terra Legal (Lei 11.952/09 e a Lei 13. 465/2017) que ficou conhecida como a "MP da Grilagem”, que dispõe sobre a regularização fundiária urbana e rural no âmbito da Amazônia Legal.

Assim, a territorialização desses projetos econômicos vem acompanhada da expropriação de grupos sociais com modos de vida relacionados à floresta e aos rios, ocasionando uma relação social de conflito e de estranhamentos de mundos culturais diferentes. 


\section{Transamazônica: nova fronteira de expansão \\ e áreas protegidas no estado do Amazonas}

Portanto, a prática da política estabelecida é aquela que ignora a Constituição Federal, os arcabouços jurídicos que consagraram a política ambiental e o reconhecimento dos territórios tradicionais dos povos amazônicos. Percebe-se, sobretudo no Governo atual, uma erosão nas políticas ambientais propostas pelas forças do agronegócio, que tendem a fragilizar os instrumentos de gestão do território e incentivar invasões de áreas protegidas na região amazônica, como se registrou nos anos de 2018 e 2019 ao longo da rodovia transamazônica (Silva; Costa Silva; Lima, 2019, Mello-Théry, 2019).

\section{CONSIDERAÇÕES FINAIS}

As políticas territoriais implementadas na Amazônia, desde o início da ditadura militar, priorizaram a perspectiva da região como produtora de matérias-primas fundamentais para o crescimento econômico do país. Essas políticas sustentaram a colonização agrícola, migração, projetos agropecuários, mineração e energia elétrica; construção de uma malha rodoviária que se converteu em frentes de expansão do desmatamento e que, atualmente, se direcionam às sub-regiões amazônicas mais protegidas. Na década de 1990, com base nos princípios do desenvolvimento sustentável, o Governo Federal e os estados da Amazônia Legal instituíram um conjunto de políticas públicas ambiental e territorial para a ampliação das áreas protegidas, gestão do território e estímulos às economias sustentáveis.

Ainda assim, os macroprojetos econômicos pensados para a região continuam os mesmos: mineração, hidrelétrica, mercados de terras, grilagem de terras públicas, extração ilegal de madeira, pecuária e agronegócio da soja. Como demonstrado, tais evidências são encontradas ao longo da rodovia BR-230 (transamazônica). Na dinâmica territorial da fronteira, a institucionalidade das áreas protegidas foi considerada como a possibilidade real de frear o desmatamento na região, no entanto, hoje, na atual conjuntura política do Brasil, as áreas protegidas e os territórios tradicionais são indicados como obstáculo à marcha do desenvolvimento econômico, um modelo que já demonstrou seus limites.

Conclui-se que as políticas territoriais estruturam a região amazônica para proporcionar uma suposta integração aos circuitos econômicos nacionais, tendo nas rodovias os eixos de expansão e conexão. Esse processo se atualiza com o reavivamento da rodovia BR-230 como uma nova frente de expansão da fronteira, que se realiza em territórios 
ordenados, com áreas públicas destinadas à proteção ambiental e ao reconhecimento de territórios tradicionais. A pressão econômica instaura novas disputas por áreas públicas já destinadas nos mecanismos jurídicos de ordenamento territorial, o que indica que a fronteira e seus agentes econômicos ultrapassam o conceito de terras devolutas para disputar territórios definidos pelo estado brasileiro.

\section{REFERÊNCIAS}

APUBLICA. O “maior desmatador do Brasil” possui 120 madeireiras na região Norte. 22 de novembro de 2019. Disponível em: www.apublica.org/2019/11/o-maior-desmatador-do-brasil-possui-120-madeireiras-na-regiao-norte/.

BECKER, Bertha K. O uso político do território: questões a partir de uma visão do terceiro mundo. In: BECKER, BK; COSTA, RH. (Orgs). Abordagens políticas da espacialidade 1983. Rio de Janeiro: UFRJ,1983, p. 1-21.

BECKER, Bertha. Amazônia: geopolítica na virada do III milênio. Rio de Janeiro: Garamond, 2004.

BECKER, Bertha K.; EGLER, Claudio. Detalhamento da metodologia para execução do zoneamento ecológico econômico pelos estados da Amazônia. Rio de Janeiro: SAE-Secretaria de Assuntos Estratégicos/Ministério do Meio Ambiente. 1997. p. 43.

BRASIL. Lei 9.985 de 18 de julho de 2000. Institui o Sistema Nacional de Unidades de Conservação da Natureza. Ministério do Meio Ambiente, 2000. Disponível: www.planalto.gov.br/ccivil_03/leis/L9985.htm. Acesso em: 27 nov. 2019.

BRASIL. Plano Amazônia Sustentável: diretrizes para o desenvolvimento sustentável na Amazônia Brasileira, 2008. Disponível em: www.planalto. gov.br/ccivil_03/_Ato2007-2010/2010/Decreto/D7378.htm. Acesso em: 20 jun. $201 \overline{9}$.

CASTRO, E. Dinâmica Socioeconômica e desmatamento na Amazônia. Novos Cadernos NAEA, Belém, 8 (2), 5-39, 2005.

COSTA SILVA, R. G. Avanços dos espaços da globalização: a produção de soja em Rondônia. 169 f. Dissertação (Mestrado em Desenvolvimento Regional e Meio Ambiente) - Universidade Federal de Rondônia, Porto Velho, 2005.

COSTA SILVA, R. G; CONCEIÇÃO, F. S. Agronegócio e campesinato na Amazônia brasileira: transformações geográficas em duas regiões nos 
estados de Rondônia e Pará. Geographia (UFF), v. 19, p. 54-72, 2017. Disponível em: www.geographia.uff.br/index.php/geographia/article/ view/1008.

COSTA SILVA, R. G; SILVA, V. V; LIMA, L. A. P. Os novos eixos da fronteira na Amazônia ocidental. Confins (PARIS), v. 43, p. 1-6, 2019. Disponível em: www.journals.openedition.org/confins/24950.

COSTA SILVA, R. G. Da apropriação da terra ao domínio do território: as estratégias do agronegócio na Amazônia Brasileira. Internacional Journal of Development Research, v.07 (12), 17699-17707, 2017. Disponível em: www.journallijdr.com/sites/default/files/issue-pdf/11514_0. pdf. Acesso em: 19 maio 2019.

GALUCH, M.V. e MENEZES, T.C.C. Da reforma agrária ao agronegócio: notas sobre dinâmicas territoriais na fronteira agropecuária amazônica e partir do município de Apuí (sul do Amazonas). Estudos Sociedade e Agricultura, Rio de Janeiro, v. 28, n. 2, p. 288-412, jun. 2020.

GELPI, A.; KALIL, R. M. L. Planejamento e gestão do território: escalas, conflitos e incertezas. Revista Cidades, v. 12, n. 20, 2015.

HUERTAS, D. M. Da fachada atlântica à imensidão amazônica: fronteira agrícola e integração territorial. São Paulo: Annablume; Fapesp; Belém: Banco da Amazônia. 2009. p. 244.

IPAM. Instituto de Pesquisa Ambiental da Amazônia. Amazonas em chamas (nota técnica). Disponível em: www.ipam.org.br. Acesso em: 10 set. 2019.

INPE. Programa de monitoramento da Amazônia e demais biomas. Desmatamento - Amazônia Legal - Disponível em: www.terrabrasilis.dpi. inpe.br/downloads/. Acesso em: 14 dez. 2019.

LIMA, L. A. P.; COSTA SILVA, R. G. Cartografia das hidroestratégias na Amazônia Brasileira. Acta Geográfica, Boa Vista, v. 12, n. 28, p. 129$142,2018$.

LOUREIRO, V. R. A Amazônia no século XXI: novas formas de desenvolvimento. São Paulo: Editora Empório do Livro, 2009. p. 279.

MELLO, N. A. de; PASQUIS, R; THÉRY, H. 2004. L'Amazonie "durable” de Marina Silva. In: Pour comprendre le Brésil de Lula. Paris: L'Harmattan, 2004. p. 169-183.

MELlO, N. A. Políticas territoriais na Amazônia. São Paulo, Brasil: Annablume, 2006.

MELLO-THÉRY, N. A. de. Território e gestão na Amazônia: terras públicas e os dilemas do Estado. São Paulo: Annablume, 2011. 
MENEZES, T. C. C. A regularização fundiária e as novas formas de expropriação rural na Amazônia. Estudos Sociedade e Agricultura, v. 23 (1), p. 110-130, 2015.

MESQUITA, B. A. A dinâmica recente do crescimento do agronegócio na Amazônia e a disputa por territórios. In: SAUER, S.; ALMEIDA, W. (Org.). Terras e territórios na Amazônia: demandas, desafios e perspectivas. Brasília: Editora Universidade de Brasília, 2011, v. 1, p. 45-68.

OLIVEIRA NETO, T. Rodovia Transamazônica: o projeto de integração deu certo? Revista de Gestão e Políticas Públicas. v. 5 (2), p. 284-308, 2015.

SANTOS, F. P. dos. Gestão de UCs no Amazonas: avanços e desafios para a conservação ambiental. Revista Geonorte, Manaus, v. 8, n. 1, p. 102-124, 2013.

SILVA, V. V; COSTA SILVA, R. G; LIMA, L. A. P. A estruturação da fronteira agrícola no sul do Estado do Amazonas. Geographia Opportuno Tempore, v. 5, p. 67-82, 2019. Disponível em: www.uel.br/revistas/ uel/index.php/Geographia/article/view/37193.

VILLARROEL, L. C. L.; TONI, F. Política e meio ambiente: a inclusão das unidades de conservação na agenda de governo do estado do Amazonas. Raízes, Campina Grande, v. 32, n. 1, p. 96-109. jan/jun. 2012. 


\title{
BR-364 - NOS CONFINS DA FRONTEIRA OESTE DO BRASIL: \\ UMA VIA PARA A INTEGRAÇÃO RODOVIÁRIA DO ACRE (CruZeiro do SUl) COM UCAyalli (Pucallpa) ${ }^{1}$
}

\author{
Ednilson Gomes da Silva" \\ Silvio Simione da Silva"*
}

\section{INTRODUÇÃO}

Este é um estudo que busca compreender prognosticamente os possíveis efeitos de projetos de políticas de integração regional e binacional no extremo oeste brasileiro (Acre, BR) com o leste peruano (Ucayali, PE). Nisso, focou-se na questão do que está ocorrendo cotidianamente na faixa de fronteira internacional, que antes era referida como território esquecido, todavia atualmente se institui uma possibilidade de integração internacional. As dinâmicas sociais e econômicas que embora em sua maioria sejam ilegais e contraventoras, já nos apontam as potencialidades de uma ligação terrestre nessa faixa limítrofe.

Cabe considerar que a fronteira como tema de estudos na ciência geográfica apresenta-se amplamente significativa por envolver uma série de questões relacionadas ao processo de ocupação de zonas limítrofes, como a formação dos limites políticos-administrativos, econômicos e das inter-relações culturais. Assim, ao abordar uma área de fronteira entre dois países estaremos nos inserindo em questões complexas que

\footnotetext{
$\overline{1}$ Artigo publicado como resultado da de mestrado desenvolvida no Programa de Pósgraduação Mestrado e Doutorado em Geografia - PPGG/UNIR, sob a orientação do professor Ricardo Gilson da Costa Silva e coorientação do professor Silvio Simione da Silva. SILVA, E. G.; SILVA, S. S. BR-364 - Nos confins da fronteira oeste do Brasil: uma via para integração rodoviária do Acre (Cruzeiro do Sul) com Ucayalli (Pucallpa). Revista Ciência Geográfica - Bauru, XXIV, Vol. XXIV (2), p. 554-575, Jan/Dez, 2020.

https://orcid.org/0000-0003-2953-1780

" https://orcid.org/0000-0001-5348-9899
} 


\section{Geografia, território e sociedade na Amazônia}

ultrapassam a delimitação de territórios, se conflitam e se complementam entre os lados diferentes das nacionalidades em questão.

Então, entende-se que o limite fronteiriço entre duas nações separa territórios nacionais, mas contraditoriamente as faixas de fronteira tem uma formação territorial em que se integram, se completam pelas relações de sociabilidade, complementariedade e compartilhamento de convivência social e na produção econômica. Assim, se a condição de ser Nacional divide, divergem e conflitam em muitas situações; na condição estar próximo, de se completar, mesmo sendo diferente, faz da faixa de fronteira um território específico com dinâmicas próprias. Assim, a fronteira é o local de antagonismos de encontro e desencontro, numa dialética que o reconhecimento do que é do outro forma o limite para se reconhecer o que é seu; seu pertencimento, que se manifesta sejam pela natureza econômica, espacial ou cultural e até política. Contudo, a integração entre pontos diversos na faixa da fronteira em geral, se processa em áreas contínuas, mas dinamizada pela articulação de circuitos de redes de transportes, informações e cooperação que se originam distantes, todavia interconecta com o local ou até sobrepõem tendo-o apenas como trajeto de conexões globais.

Assim, interligar duas cidades de diferentes países por meios rodoviários consiste em criar bases físicas para abrir a faixa fronteiriça para sua complementação interna, mas também para o mercado global com sua submissão nas transformações geográficas, especialmente no meio natural, social, econômico e cultural. Diante dessas considerações, aqui se pretende analisar a fronteira binacional do extremo oeste brasileiro com o leste peruano, sob duas conjunturas: a primeira se dá a partir das relações de um circuito de inter-relação informal que ocorre por via fluvial e por estradas vicinais clandestinas que possibilitam atividades ilegais como o contrabando de mercadorias, madeiras e o tráfico internacional de drogas; a segunda conjuntura consiste em analisar a possibilidade de concretizar agora uma proposta pretérita de integração terrestre entre as cidades de Cruzeiro do Sul, Acre (BR) e Pucallpa, Ucayali (PE). Estas cidades formam centros regionais que desempenham papel de importância econômica nas faixas de fronteira brasileira e peruana, com ligações não formais, em que muitas destas se processam na ilegalidade.

Nesse contexto, por este estudo buscamos adentrar a uma investigação de como este processo de integração terrestre contribuiria na formação de uma rede de transporte interligada em escala local, mas com efeito global, potencializando fluxos socioeconômicos e transfor- 


\section{BR-364 - nos confins da fronteira oeste do Brasil}

mações geográficas, nessa parte até então bastante remota da Amazônia Sul-Ocidental. Atualmente, as principais inter-relações de Cruzeiro do Sul e Pucallpa ocorrem de formas ilícitas com fluxos comerciais ilegais, por meio de trilhas na floresta que facilitam a existência de um circuito terrestre clandestino, em pleno funcionamento. Estes se articulam com a bacia hidrográfica do rio Ucayali, dado que essa hidrovia possui grande potencial de navegabilidade e permite integração fluvial entre as cidades Pucallpa (PE), Iquitos (PE), Manaus (BR) e Belém (BR).

Em território brasileiro as inter-relações ilegais ocorrem por meio da bacia hidrográfica do rio Juruá, sendo que a cidade de Cruzeiro do Sul funciona como um centro de direcionamento de rotas do contrabando e do tráfico internacional de drogas que usam essa via fluvial. Essas rotas, passando por Cruzeiro do Sul, seguem por via fluvial em direção a Manaus e, por via terrestre segue pela BR-364, com destino a Rio Branco (AC) e daí se busca outros centros urbanos, em especial, em direção ao Centro Sul Brasileiro.

De certa forma, os fluxos e dinâmicas legais e ilegais são responsáveis pela vivacidade dessa região de fronteira, evidenciando que se trata de uma área com potencial de consolidação de sistema de transporte fluvial e terrestre que se autocomplementará, podendo possibilitar a formação de vieses que fortaleçam o crescimento econômico da região. Ademais, para além do fato desta fronteira binacional já ser utilizada como um eixo de escoamento em direção a grandes centros urbanos (mesmo na ilegalidade), podemos dizer que a consolidação de eixos rodoviários terrestres possibilitará acesso aos portos marítimos do Pacífico e do Atlântico. Com isso, veem-se esses projetos como propósitos reais que poderão ser exitoso reforçando, de forma legal, mecanismos favoráveis ao desenvolvimento regional.

Por sua posição singular, Cruzeiro do Sul e Pucallpa formam espaços estruturados dentro de suas faixas de fronteiras respectivas ${ }^{2}$,

\footnotetext{
${ }^{2}$ Cabe esclarecer que a faixa de fronteira no Brasil é de $150 \mathrm{~km}$ (Lei 6.634, 2/051979). Já as "Constituições do Peru e da Bolívia preveem comportamentos especiais quanto à propriedade de terras e a exploração econômica. Numa faixa interna de $50 \mathrm{~km}$ junto à fronteira" (STEIMAN, 2002, p.28). Sendo assim, a cidade de Cruzeiro do Sul está situada dentro da faixa de fronteira brasileira; já a cidade de Pucallpa não está situada dentro da faixa de fronteira peruana. Contudo, como capital regional, ocupa a condição de centro mais importante no leste amazônico peruano, o que lhe confere a condição de cidade de fronteira (mais econômica que política).
} 
mas que até o momento, legalmente se realizam comercial e socialmente pelos fluxos socioeconômicos nacionais internos, voltados em direção aos centros nacionais de cada país. Assim, pelas localizações finais em rotas trafegáveis de cada país, há uma imagem de estagnação que lhes é constantemente atribuída. Contudo, isto é muito parcial, pois estão inseridas redes nacionais que ampliam sua capacidade relacional e nacional, por terra e por água; sem contar que, como já tratamos, há aquelas rotas que clandestinamente se formam, dando um desenho inicial do que é projetada para futura integração regional.

Então, trata-se de duas cidades distantes dos centros econômicos de seus países, mas que possuem vias de transporte rodoviárias e fluviais que ligam até sua região, sendo, contudo, fins de linhas destas conexões nacionais. Porém, há um potencial de interconexão interna entre as faixas de fronteira, sendo que é aí que está projetada a futura integração oeste do Brasil com o Peru. Isso sim seria estrategicamente a abertura de uma rota internacional, com controle das redes de contraventoras existentes e maior potencial de cooperação e crescimento técnico e econômico de ambos os lados da fronteira, nessa porção territorial sul-americana.

Tal integração ocupa a parte oeste do estado do Acre, dando continuidade ao Eixo de Integração e desenvolvimento (EID/IIRSA) BrasilPeru-Bolívia, que já tem vias ativas, pelo sul do estado na cidade de Assis Brasil (BR) e Iñapari (PE), conforme Figura 1: 


\section{BR-364 - nos confins da fronteira oeste do Brasil}

Figura 1 - Eixo de desenvolvimento e integração Acre (BR) e Peru.

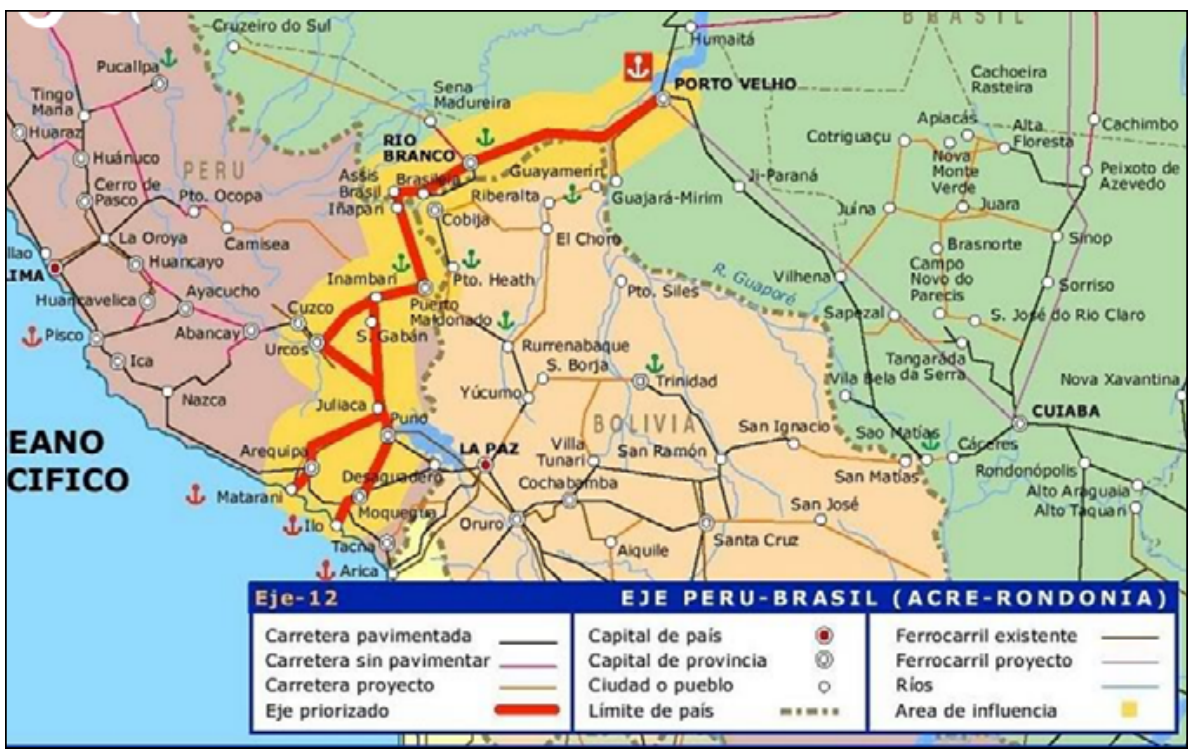

Fonte: Fórum Social Pan-amazônico, 2017.

Figura 2 - Zona Fronteiriça Extremo Oeste do Brasil como o Leste do Peru.

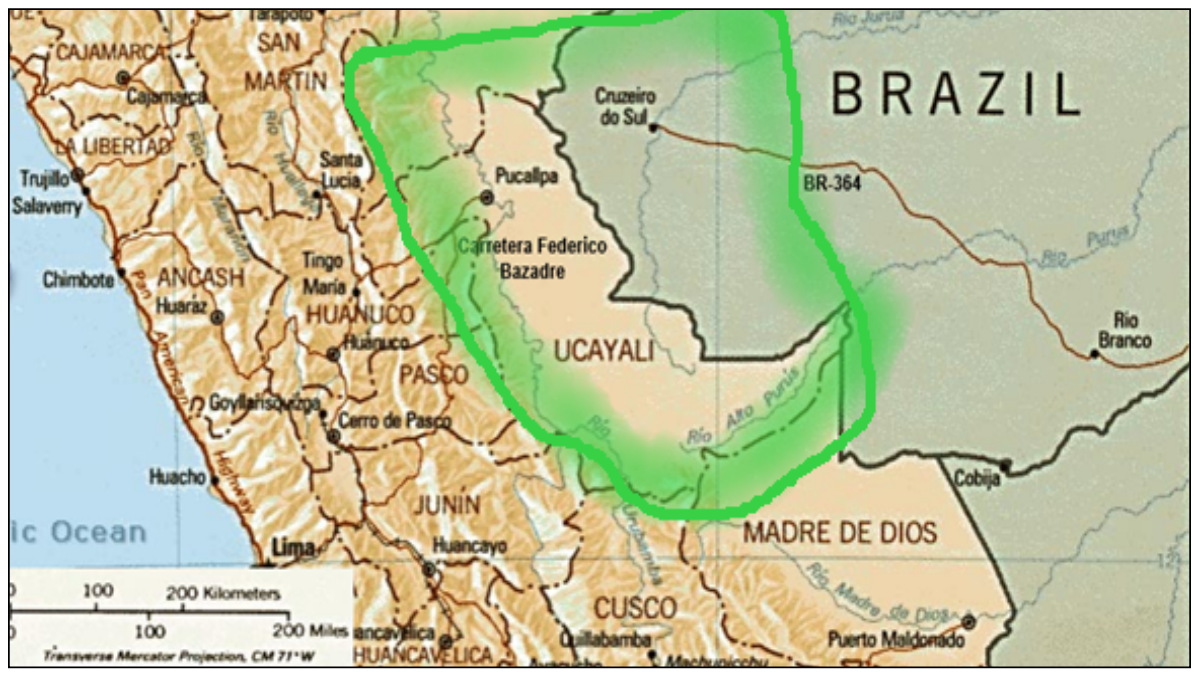

Fonte: Guia Geográfico, 2019. 


\section{Geografia, território e sociedade na Amazônia}

Já na figura acima (Figura 2), apresentamos o mapa da região de fronteira entre Brasil e Peru, no trecho projetado na curta distância entre Cruzeiro do Sul e Pucallpa. No desenho dessas redes de transportes, pode se ver a possibilidade da intermodalidade com vias fluviais dos rios Ucayali e Juruá, através das rodovias de BR-364 (que liga Rio Branco a Cruzeiro do Sul) e da "Carretera" Federal Peruana Federico Basadre que liga a cidade de Pucallpa a capital peruana - a cidade de Lima (Ucayali, 2019).

Cabe reforçar que as cidades de Cruzeiro do Sul e Pucallpa estão localizadas em plena região amazônica, com uma rica bacia hidrográfica navegável que possibilita fluxos comerciais no atendimento de amplas áreas polarizadas, onde centraliza a distribuição de mercadorias, serviços e informações. Ambas compartilham de um mesmo contexto histórico e posicionamento econômico interno atrelado, em parte, ao isolamento terrestre dos grandes centros e ao esquecimento por parte dos principais gestores federais de seus respectivos países. Nesse sentido, o projeto de integração regional entre as duas cidades se posiciona como um recorte espacial a ser lembrado em cenário internacional. Em que esta região binacional deixará de ser o final das rodovias nacionais para serem trechos de passagem na integração dos dois países, tal como no plano corredor bioceânico na América do Sul. A concretização desse eixo rodoviário virá confirmar no futuro uma conexão da BR-364 com as principais rodovias peruanas e daí com áreas litorâneas no Oceano Pacífico.

É a partir disso que objetivamos, com base nos estudos geográficos, caracterizar essa faixa de fronteira e analisar as relações espaciais perante a necessidade de políticas públicas que possam promover a construção desse eixo rodoviário integrador, ligando as duas cidades e aproximando-as, embora seus sítios urbanos estejam fora da linha limítrofe internacional. Tais ações de integração ocasionarão a possibilidade de maior abertura aos mercados internos da América do Sul, nesta porção sudoeste amazônica em terras até então pouco exploradas. Nesse sentido, no que diz respeito à área estudada, isso facilitaria que cada vez mais os fluxos comerciais entre Cruzeiro do Sul e Pucallpa se intensificassem, tendo um circuito de integração com possibilidades de explorar, inclusive, formas intermodais de transporte por vias terrestres e fluviais.

Ademais, cabe ressaltar que a rodovia internacional, nessa área, faz parte de um plano estratégico de integração e expansão do capital previsto na América do Sul, mas que remonta aos planos de governos brasileiros dos finais da década de 1950. Depois de colocada no esquecimento por tempos, apenas recentemente tem sido retomada no contexto 


\section{BR-364 - nos confins da fronteira oeste do Brasil}

das políticas de integração regional sul-americano (IIRSA), após os anos 2000, notando-se no relato a seguir:

A partir do ano 2003 os presidentes do Brasil e Peru, Luiz Inácio Lula da Silva e Alejandro Toledo, respectivamente, decidiram fortalecer e consolidar as relações bilaterais entre os dois países, com o propósito de avançar na construção de uma aliança estratégica. $\mathrm{Na}$ oportunidade foram constatadas importantes convergências sobre a visão compartilhada de cooperação e integração o que orientaram as relações bilaterais, destacando-se como elementos fundamentais como: complementação das economias, promoção do comércio, interconexão física, investimentos em turismo, combate ao narcotráfico, desenvolvimento de cooperação técnica para a preservação do meio ambiente, proteção dos recursos naturais buscando o desenvolvimento sustentável e a luta contra a pobreza (Fórum Binacional, 2006, p. 2-3).

Como resultado de tudo isso, as ações institucionais que já estavam em curso nesse período começam a ganhar corpo, ainda na primeira década deste século:

Com o objetivo de promover o estreitamento das relações comerciais fronteiriças entre o estado do Acre no Brasil, e a região de Ucayali no Peru, o presidente da região Ucayali, Edwin Vasquez, na oportunidade da visita do governador do Acre, Jorge Viana em 12 de Março de 2004 a Pucallpa, assinaram uma Ata de Intenção para o desenvolvimento do eixo comercial e de integração Pucallpa (Cruzeiro do Sul), estabelecendo um diálogo mais aberto para a implementação de ações conjuntas de estreitamento comercial, cultural, ambiental, turístico e de cooperação técnica. Reforçando essa iniciativa, em 23 de abril de 2004, durante a visita do ministro das relações exteriores do Peru ao Acre, senhor Manuel Rodriguez, foram assinados mais dois documentos, Ata de Instalação da Secretaria Técnica do Estado do Acre e o Governo Regional de Ucayali, e o "Memorando de Entendimento No 001/2004 ST", que tiveram como objetivo estabelecer ações concretas de nivelamento socioambiental, captação de recursos, e estabelecimento de projetos básicos para ações conjuntas (Fórum Binacional, 2006, p. 2).

Com isso, teve-se a criação do Fórum Binacional fazendo avançar as discussões sobre a integração nos anos seguintes. Já em nível regional, nos anos de 2018 e 2019 essa discussão ganhou mais forças 


\section{Geografia, território e sociedade na Amazônia}

ao ser incorporado como parte dos discursos de autoridades do estado do Acre e da região de Ucayali. Esses, agora, justificam a necessidade de cooperação em atividades econômicas e sociais, mas também na resolução de problemas comuns que transcendem as fronteiras e fogem do escopo de cada soberania nacional, tais como a preservação do meio ambiente, a proteção às culturas tradicionais e às terras indígenas, combate ao tráfico de drogas, etc.

A fronteira entre Cruzeiro do Sul e Pucallpa, nesse contexto, além da perspectiva de desenvolvimento econômico-social local, agora se apresenta como espaço aberto para os acordos bilaterais e a consolidação de vias físicas estruturais, permitindo acesso aos recursos naturais ainda não explorados. Assim, caracterizar a fronteira aqui, significa uma análise geográfica de uma região que pode emergir no cenário internacional com potenciais de impulsos econômicos expostos a partir dos circuitos rodoviários, abrindo-se para novas relações de produção e exploração. Nesse sentindo, há pontos positivos e negativos a serem considerados adiante.

\section{A GEOGRAFIA DA FRONTEIRA E AS SUAS INTERFACES}

Para se situar melhor nestas situações, primeiramente se faz necessário abordar conceitualmente a fronteira política e alguns conceitos que se aproximam e que, muitas vezes, são tratados de formas errôneas como sinônimos, tendo implicação para a análise como a aqui proposta. A fronteira, aparentemente de conceituação bem simples e de fácil compreensão no senso comum, é concebida como linhas limítrofes geográficas, cujas imagens traduzem os limites espaciais definidos numa determinada formação socioespacial, isto é, significa considerar como um espaço de influência de poder de determinados grupos formados por elementos demográficos, culturais, econômicos e políticos; e, desse modo, define-se como diferentes territórios, demonstrando onde começa e termina os domínios de um e de outro. De forma geral, assim a fronteira é concebida como um limite de território e um ponto de finalização de influências externas, visando garantir a soberania e perpetuação do poder interno. Tais definições de limites podem, assim, serem concebidas como uma linha imaginária (coordenadas geográficas) ou definidas por elementos naturais como rios ou montanhas, formando um referencial físico da divisão entre duas ou mais unidades políticas. 


\section{BR-364 - nos confins da fronteira oeste do Brasil}

No entanto, a fronteira não pode ser concebida apenas como um limite político-administrativo que agrega ou segregam diferentes grupos sociais. Assim, ela não pode ser vista apenas como linhas divisórias simples, mas como faixas de terras que se encontram aqueles que ali vivem; como território de interação, de complementação, e, sobretudo, de alteridade, onde um reconhece o que é do outro e legitima sua condição essencial de pertencimento ao defender e resguardar sua condição de ser e estar num lugar. Não se trata de um elemento inerte, mas sim de grande vivacidade, formado por fluxos entre os atores sociais que nela circulam. Nesse contexto, a fronteira contém em si um elemento que a divide, ou seja, uma "linha divisora", o "limite" (o marco físico, o rio, o monte, a linha convencionada), sendo este onde a alteridade ganha visualização física. Portanto, fronteira é mais que limite, é área (faixa) de interação, de complementação, de conflitos/superação que comporta o limite (estes sim, o marco da existência física da divisão territorial). Assim, se a fronteira (faixas) se complementa, em contrapartida os limites a separam entre si.

Desta forma, na geografia, são conceitos bastantes discutidos por representar antagonismos sociais e econômicos que diretamente provocam transformações no espaço. Nesse contexto, para Becker (1983), a fronteira é percebida de forma diferenciada pelos atores sociais. Para a nação, ela é símbolo e fato político de primeira grandeza, como espaço de projeção potencialmente alternativo para o futuro. Nesse entendimento, a potencialidade econômica e política da fronteira transfigura a região como estratégica para o Estado, que se empenha pela sua rápida estruturação e controle. Dessa forma, $\operatorname{Becker}(1988$, p. 67) reforça que:

[...] a fronteira contém assim os elementos essenciais do modo de produção dominante e da formação econômica e social em que se situa, mas é um espaço não plenamente estruturado, dinâmico, onde as relações e as práticas não assumem o grau de cristalização comum em outras circunstâncias e, portanto, gerador de realidades novas e dotado de elevado potencial político.

Nesse sentido, a autora compreende a fronteira como espaço dinâmico e contraditório que se impõe por uma concepção de espaço que no seu lento movimento promove o encontro do local com o global. As racionalidades de interesses gerais e estratégicos representadas pelo Estado e empresas situam-se, às vezes, de formas contraditórias ou complementares às práticas e concepções do espaço local. Dessa maneira a 


\section{Geografia, território e sociedade na Amazônia}

fronteira, com sua condição de espaço de trânsito social e econômico em dois ou mais países, está exposta aos efeitos de decisões tomadas de um lado como de outro da linha limítrofes que os separam. Tudo isso, interfere na vida social desses lugares que se desenvolve de forma inter-relacionada (embora se vejam como pertencentes a nacionalidades diferentes) no conjunto territorial da faixa por onde circulam em seu cotidiano vivencial. Assim, vemos que a fronteira é um espaço aberto e de constante transformação, por meios das relações socioeconômicas e dos fluxos que nela acontecem. A fronteira representa um "espaço vivo" que ultrapassa limites políticos pré-estabelecidos, não se confundindo com o limite que restringe e simboliza a separação de dois espaços diferentes produzidos (Machado, 1998).

Seguindo essa lógica, Becker (2006, p. 57), assinalou que “as zonas de fronteira correspondem a uma área de interpenetração mútua e de constante manipulação de estruturas sociopolíticas e culturais distintas". Ademais, cada lado da "fronteira apresenta estruturas culturais, sociais, econômicas, políticas e demográficas diferenciadas", mas que se complementam nas inter-relações que se travam no convívio socioespacial estabelecido. Desta forma, caracterizam-se, por serem locais de instabilidade e mutabilidade, podendo surgir reações e conflitos de diferentes naturezas (nacionalistas, libertadores, econômicas, etc.), a partir, tanto das aspirações das populações locais, como de pressões externas.

Atualmente, perante a lógica da globalização econômica, as barreiras físicas de séculos passados que segregavam espaços políticos já não fazem mais sentido. $\mathrm{Na}$ atualidade, a fronteira é o local de flexibilização econômica, social e cultural em suas manifestações de complementariedade e formação de uma identidade socioespacial de quem vive em condições de territórios limítrofes. Falar de fronteira, agora, é se voltar para interpretação dos fenômenos econômicos e sociais que acontecem ou podem vir a acontecer, sobretudo, por meio da busca da integração entre diferentes espaços nacionais que compartilham de condições geográficas existenciais próximas.

Geopoliticamente, a faixa de fronteira corresponde uma área considerada de defesa contra possíveis invasores - isto é, área de Segurança Nacional. Por isso, mesmo estando subordinadas as ações em nível estadual e ter uma vida social própria e específica, ela se submete à jurisdição Federal, sendo áreas prioritárias para possíveis ações militares. Porém, na condição de territórios limítrofes, a faixa de fronteira e suas bordas podem ser locais onde se encontram muitas cidades, povoados, comunidades 


\section{BR-364 - nos confins da fronteira oeste do Brasil}

campesinas e indígenas ou mesmo terras de florestas desabitadas. Como faixas de segurança nacionais, estes territórios estão mais expostos a determinação externa vindas de áreas centrais dos países; nisso reside a condição que lhes são muito conflitivas. Por outro lado, essas áreas são muito importantes, pois são nas bordas entre dois espaços de fronteira que ocorrem as principais relações sociais, econômicas e culturais, formando também regiões de forte influência externa para ambos os lados.

No caso da Amazônia sul-americana estas bordas são habitadas por uma significativa população indígena. Isso, por si, já marca a fronteira com certa fluidez nos limites, pois estes povos podem ter parte de seus territórios nativos divididos entre dois países (como os Manchineri [Piro, no Peru] que estão no Brasil e no Peru, no estado do Acre [BR] e em Madre de Dios [PE]), transitando de ambos os lados da fronteira. Tem que se considerar ainda que estas bordas de fronteira são extensas e em grande parte pouco povoadas, mesmo por povos nativos. Isso as torna portadoras de um cenário de ações ilegais como o narcotráfico, facilitado pela quase ausência do Estado nesses lugares.

De forma geral, as bordas são assim, cenários principais de interação e fluxos (legais e ilegais) em escala imediata e local, independe de ser povoado ou não. A borda fronteiriça entre Cruzeiro do Sul e Pucallpa, aqui parte de nosso espaço de estudo, são áreas de densa floresta, na qual predominam os fluxos ilegais de contrabando de madeira, invasões a terra indígenas, trilhas clandestinas funcionando como corredor do tráfico internacional de drogas. Nesse sentido, independente da legalidade ou não, tudo isso nos mostra que já existe uma vivacidade na borda desta fronteira do oeste acreano com o leste peruano.

\section{Projeto “rota internacional”: Cruzeiro do Sul/Pucallpa}

No contexto da fronteira aqui apresentado, a possibilidade de consolidação de um processo de integração internacional consiste no eixo terrestre que foi planejado no passado como uma alternativa de escoamento da produção, abrindo mais um circuito com fluxos para os portos marítimos da costa litorânea peruana. Isso se trata de um projeto para uma possível rota de integração de um percurso terrestre mais curto entre Brasil e o litoral do Peru, do que o atual existente intitulado de "Rodovia do Pacífico". Este percurso existente se dá por meio da BR-317, que liga a cidade de Rio Branco a Assis Brasil (sul do estado do Acre) conectado à "Carretera Transoceânica" na pequena cidade 


\section{Geografia, território e sociedade na Amazônia}

Iñapari (Madre de Dios, Peru) e seguindo a até o Porto de Illo, no litoral sul peruano.

Como já vimos, trata-se de apresentar as possibilidades e necessidades da concretização de uma rodovia internacional entre as cidades de Cruzeiro do Sul (Acre) e Pucallpa (Ucayalli) que se posicionará como possíveis locais para fortalecimento de estratégias de aproximação de mercados locais, regionais e globais. Cabe ressaltar que essa integração é um projeto antigo, e foi previsto no plano de metas do presidente Juscelino Kubitschek (1956 e 1961) como parte de uma série de investimentos rodoviários, sobretudo de integração da Amazônia. No caso específico, foi planejado a BR-029 que, posteriormente, viria a se chamar de BR-364 que tinha como projeto original ligar São Paulo e Brasília em direção ao Centro-Oeste e Amazônia, sobretudo os estados de Mato Grosso, Rondônia e Acre. O término desta rodovia estava previsto de ser na comunidade Boqueirão da Esperança, localizada no município de Cruzeiro do Sul (AC), em plena fronteira, na linha limítrofe com o país vizinho Peru. O trajeto dessa rodovia já visava, naquela época, a integração com a cidade de Pucallpa (Peru). A trilha para rodovia chegou a ser aberta pelo Exército Brasileiro e, posteriormente, foi abandonada, ficando apenas a "clareira" na floresta nas proximidades da fronteira (Kamp, 2002).

Geograficamente, trata-se de um projeto com uma nova rota internacional, com efeitos em transformações socioeconômicas e consequentemente estruturais no espaço regional produzido. Nisso, o projeto marcará uma nova reconfiguração que ultrapassa a escala local, movendo-se para mercados globais com abertura regional de seus potenciais de recursos naturais vegetais e minerais aos interesses do capitalismo, para muito além destas fronteiras.

Assim, dado que já existe uma ligação do Acre com o Peru (Rio Branco a Porto Maldonado, via cidade de Assis Brasil), cabe aqui ressaltar que a integração terrestre de Cruzeiro do Sul a Pucallpa permitirá ao Acre outra conexão internacional, agora pela mesorregião do Vale do Juruá. Com isso, se antes o Acre era "fim de linhas" das rodovias, terá então conexão externa tanto no plano Norte-Sul, como no plano Oeste-Leste. Os impactos positivos dessa alternativa de integração binacional, no fortalecimento do desenvolvimento econômico da região, ocorrerão com mais ênfase no oeste acreano, firmando Cruzeiro do Sul como enclave central e estratégico no extremo oeste brasileiro. Ademais, essa rodovia permitirá uma integração intermodal como um corredor de fluxos socioeconômicos dos grandes centros brasileiros em 


\section{BR-364 - nos confins da fronteira oeste do Brasil}

direção aos portos peruanos, mas também por hidrovias com conexões terrestres e fluviais através dos rios Juruá e Ucayali em direção ao rio Amazonas.

Um fato importante sob esta perspectiva de consolidação desse novo eixo de integração é considerar a redução do tempo de viagem rodoviária entre a cidade de Cruzeiro do Sul até a cidade de Lima-Peru. Levando-se em consideração que a distância de Cruzeiro do Sul até a capital Peruana, utilizando-se desse possível "novo eixo" de integração terrestre, via Pucallpa, consiste em aproximadamente 1.100 quilômetros. $\mathrm{O}$ que evidencia ser um percurso bem menor do existente que se dá por meio da rodovia BR-364, que liga Cruzeiro do Sul a Rio Branco, em torno de 635 quilômetros e depois por meio da Rodovia BR-317 (Rodovia do Pacífico) que liga Rio Branco a Lima (PE) equivalente a 2200 quilômetros. Isso significa que o trecho de Cruzeiro do Sul (AC/ BR) a Lima (Província de Lima, PE), somado, equivale a aproximadamente 2.835 quilômetros, ao passo que o novo percurso corresponde a menos que a metade dessa distância (Maia, 2019, p. 1). Assim, as atuais discussões sobre integração entre os governos do Acre e Ucayali, levam em consideração que o novo eixo terrestre aproximará os mercados, possibilitando fluxos da produção e passageiros, em menor tempo.

Considerando as distâncias locais, pode se dizer que a cidade de Cruzeiro do Sul, cidade principal do oeste acreano, situa-se a uma distância de aproximadamente $230 \mathrm{~km}$ da cidade de Pucallpa, capital dessa regional peruana. Essa cidade possui o trecho rodoviário pavimentado de Pucallpa, Huanuco e Lima, com aproximadamente 758 km; sendo que por esta via se vincula a rede rodoviária nacional peruana, numa distância temporal estimada de 16 horas de duração, para uma viagem terrestre em ônibus convencional (Maia, 2019, p. 1). Dessa forma, Cruzeiro do Sul (AC) está localizado próximo a um eixo rodoviário sul-americano de conexão mundial; isso significa que, os $230 \mathrm{~km}$ que separam duas cidades, representam um entrave ao Cruzeiro do Sul de conectar-se em uma rede rodoviária de efeito global.

Isto foi explicado por um político acreano da região do Juruá, demonstrando que tudo pode ser mais simples do que se pensa:

A ligação rodoviária do Acre com o Peru, através da região do Vale do Juruá, é uma obra de aparência gigantesca, mas muito fácil de ser realizada. Dos cerca de 180 quilômetros que seriam necessários para ligar as cidades de Cruzeiro do Sul, no AcreBrasil, à cidade de Pucallpa, no Peru, pelo menos 70 já existem 
e outros 25, a partir do município de Rodrigues Alves, já têm até o que os mateiros e outras pessoas que utilizam o caminho, o chamado “picadão' (Maia, 2019, p. 1).

A Figura 3 representa estes trechos. Nota-se que é curto o trecho rodoviário que falta para conectar o sistema rodoviário brasileiro ao peruano (BR-364 com a Rodovia Peruana Federico Basadre).

Figura 3 - Zona da futura integração Cruzeiro do Sul (AC/BR) e Pucallpa (UC/PE).

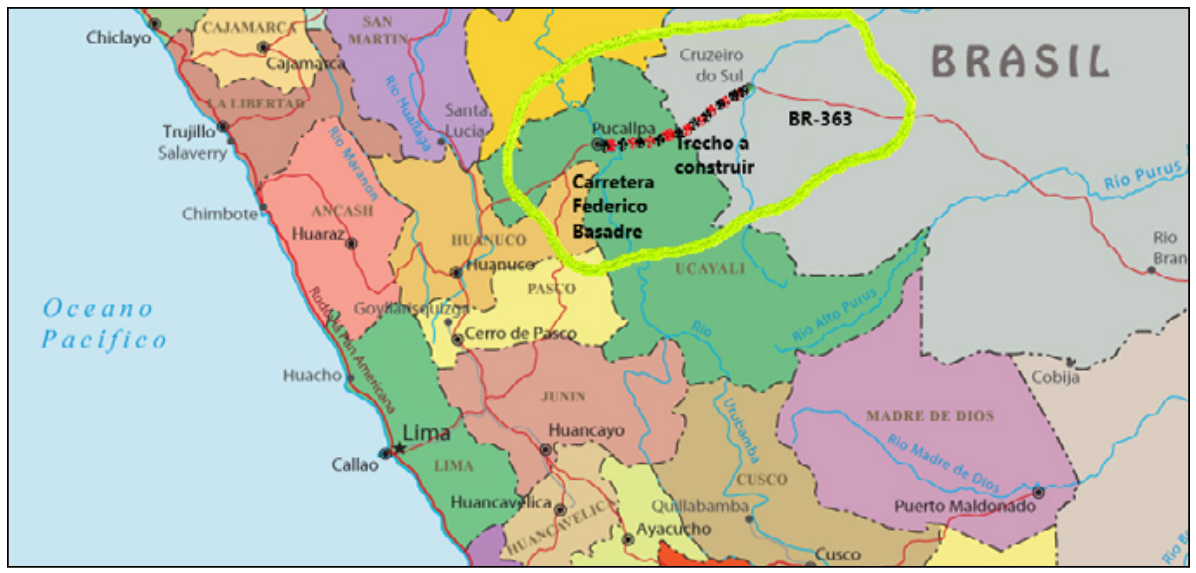

Fonte: Guia Geográfico, 2019.

Nesse sentido, integrar a fronteira entre estas duas cidades apresenta-se como uma nova opção de entrada e saída sul-americana, em direção ao Oceano Pacífico, tal como em direção ao interior do continente em rotas que também seguirão para o Oceano Atlântico; seja por terra ou por meio de hidrovias, como a bacia hidrográfica do Amazonas. A questão da integração entre ambas as cidades poderá ocasionar um processo geográfico de abertura de possibilidades do surgimento de um novo circuito de importantes relações espaciais nesta área de fronteira, no centro da América do Sul. Essa integração binacional poderá ser uma alavanca na interação de fluxos e um fator de transformação da região, levando ao surgimento de novas características espaciais e socioeconômicas em plena Amazônia peruana e brasileira. Diante deste quadro, o oeste acreano com sua cidade principal (Cruzeiro do Sul), terão maior 


\section{BR-364 - nos confins da fronteira oeste do Brasil}

relação com a cidade de Pucallpa - principal cidade do leste amazônico do Peru; e, com isso, as trocas comerciais possibilitarão efeitos de novas dinâmicas ao desenvolvimento econômico nos dos dois lados da fronteira.

Estas cidades apresentam características semelhantes naturais (vegetação, relevo, hidrografia e clima). Situam-se numa região de floresta tropical, variando entre 200 a $600 \mathrm{~m}$ de altitude e com período de chuvas e estiagem em concomitância, integrando-se a bacia hidrográfica do rio Amazonas; porém, em sub-bacias diversas, divididas pelos dois principais rios que cortam a região: Juruá e Ucayali. Nisso, formam-se importantes vias de circulação de pessoas e mercadorias em que na atualidade dinamiza a circulação regional, sem, contudo, possibilitar uma integração direta entre o lado brasileiro e peruano. Os rios Ucayali e Juruá drenam no sentido ao grande vale do Amazonas/Solimões. Desta forma, por estas características, a rodovia projetada terá papel importante na integração intermodal rodovia-hidrovia que deverá se estabelecer.

Cabe salientar que a cidade de Cruzeiro do Sul (AC), desde o início da década de 2010, tem passado por um processo de transformação geográfica em decorrência da pavimentação da BR-364, em direção à capital do estado, Rio Branco. Esta estrada hoje funciona como um eixo de integração local e nacional, possibilitado sua ligação terrestre com os principais centros econômicos brasileiros. Já a cidade de Pucallpa, como já mencionando, mantém fortes relações com o principal centro econômico peruano, a Capital Federal - Lima, por meio da "Carretera Federico Basadre".

Também como já tratamos, desde os anos de 2018 e 2019, os governos do Acre e do Departamento de Ucayali vem realizando diversas reuniões para discutir formas de promover seus processos de integração terrestre. Com isso, tem entrado em pautas a retomada da discussão de impulsionar também um voo diário entre Cruzeiro do Sul e Pucallpa, que possibilitaria aos brasileiros e peruanos maiores realizações de atividades comerciais e sociais. Os voos do trecho Pucallpa/Cruzeiro do Sul permitirão conexão com diversas rotas de transporte aéreas no Brasil

e no Peru dentre elas: Cruzeiro do Sul, Rio Branco, Brasília; Puerto Maldonado, Cuzco, Lima; Pucallpa, Huaraz, Lima entre outros.

Diante disso, percebe-se que essa integração começa a ganhar formas concretas, mesmo ainda não existindo uma ligação por meio terrestre e/ou aérea. Mas isso, vemos estar ganhando corpo quando as autoridades locais e nacionais começam a perceber o potencial econômico 


\section{Geografia, território e sociedade na Amazônia}

e a viabilidade de concretizar esse projeto. Com a integração, essa fronteira ganhará maior vivacidade por meio dos fluxos comerciais e sociais, consolidando-se em relações formais e legais em detrimento das atuais informalidades de rotas clandestinas como áreas de corredores internacionais de narcotráficos, contrabando de madeiras, seja por meio dos rios, ou de estradas vicinais não autorizadas na floresta. Agora podemos passar a tratar de especificidades de cada área em estudo.

\section{Ucayalli - Pucallpa: a regional e sua capital na fronteira leste PERUANA}

A Regional de Ucayali possui uma área de 105.097,20 $\mathrm{Km}^{2}$ equivalente a $8 \%$ do território peruano, tornando-se a segunda maior Regional do país. Segundo o Instituto nacional de Geografia do Peru, a população deste departamento em 2017, era superior a 490.000 habitantes, sendo que destes cerca de 270.000 residiam na área urbana da capital, Pucallpa. O Departamento de Ucayali limita-se ao norte com a Regional de Loreto; ao Sul com Junín, Cusco e Madre de Dios; a leste da República Federativa do Brasil (Acre); e ao Oeste com Huanuco e Pasco. Está subdividido em quatro províncias: Padre Abad, Atalaya, Purús e Coronel Portillo. Essa última é a mais populosa e economicamente importante, com uma densidade demográfica de 9,1 hab. por km2, onde situa-se a capital, Pucallpa, a maior cidade da região. É categorizada como uma metrópole regional e concentra as principais atividades industriais e fluxos socioeconômicos do centro-leste do país.

A região e a cidade tiveram suas origens com a chegada dos missionários franciscanos, por volta de 1840, que formaram um assentamento missionário de indígenas (grupo étnico shipibo-conibo), nas margens do rio Ucayali. Assim, permaneceram por décadas como um povoado isolado na floresta, para além das encostas andinas; porém, já mais próximo ao final do século XIX, com a descoberta e exploração da borracha (Hevea brasiliensis), a cidade foi oficialmente fundada, no dia 23 de maio de 1883 (Peru Inka Intertravel, 2017).

A Região de Ucayali, tendo sua localização total na floresta amazônica, possui grande riqueza de recursos naturais, com alta disponibilidade de recursos hídricos e biodiversidade florística e faunística. Dessa forma sua principal atividade econômica é a extração de madeira, seguida pela agricultura, comércio e turismo. De acordo com o governo regional de Ucayali (2019) a produção industrial representava cerca de $15 \%$ da produção regional, com um crescimento médio anual de $4 \%$ nos 
últimos 10 anos. Sua base produtiva é diversificada, com o setor agrícola sendo, atualmente, o mais importante, respondendo por $19 \%$ do valor da produção, destacando as culturas tradicionais (banana, mandioca, mamão, arroz e milho amarelo duro) que representam $78 \%$ do valor da produção agrícola; porém em tempos mais recente já se coloca como uma zona de expansão de culturas de maior valor, como o dendezeiro, o cacau, o café e o camu-camu (Ucayali, 2019).

A manufatura também tem um alto potencial de crescimento, sobretudo com as perspectivas de maior integração viária nacional e internacional com o Brasil. Essas perspectivas futuras têm proporcionado mais dinamismo dos investimentos públicos e privados, junto ao amadurecimento dos projetos integracionistas. Destaca-se ainda o alto potencial da atividade florestal como, como já mencionadas, àquelas relacionadas à extração e processamento de madeira, os serviços ambientais e a exploração de petróleo que está sendo já desenvolvido na região. O sítio urbano, no seio da floresta amazônica peruana, nasceu como uma cidade vinculada a rede hidrográfica que foi utilizada durante séculos como a principal via de circulação e locomoção de pessoas e mercadorias. O rio Ucayali drena na direção Sul-Norte, constituindo o seu eixo principal que historicamente foi o elo de integração regional interno na Amazônia peruana; isso, dado que é um rio de navegabilidade permanente, por embarcações de até três metros de profundidade (figuras 4 e 5 ). 
Geografia, território e sociedade na Amazônia

Figura 4 - Transportes de passageiros.

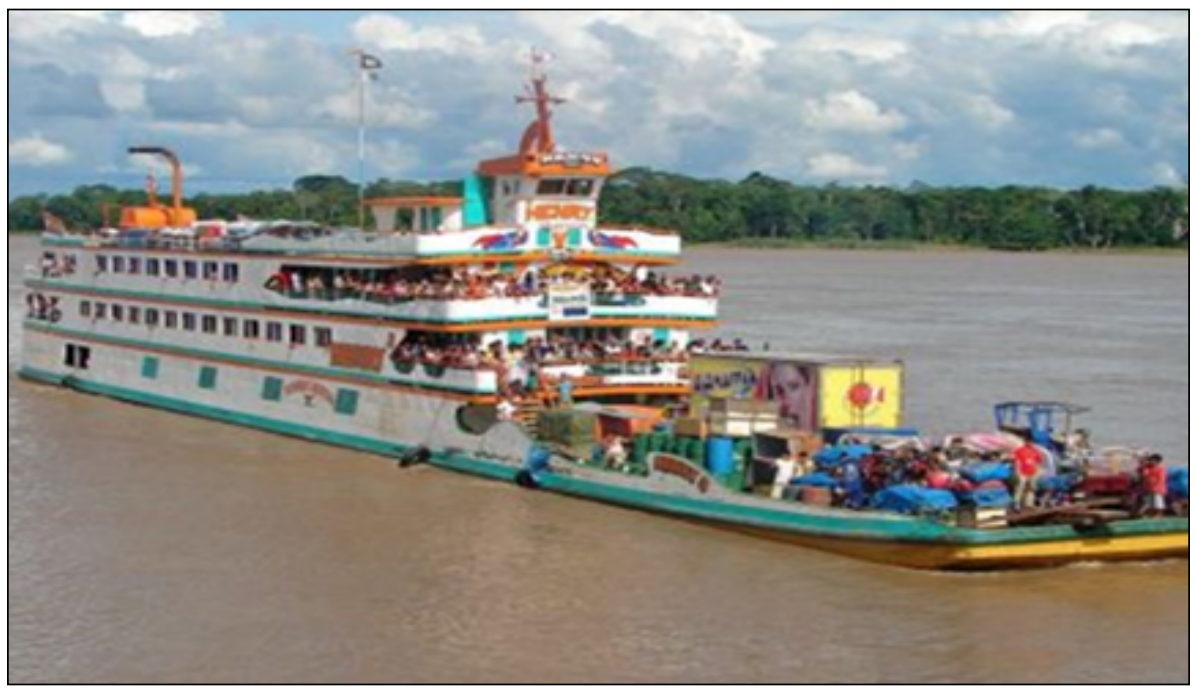

Fonte: Amazônia Altervista, 2020.

Figura 5 - Transporte de cargas no Rio Ucayalli.

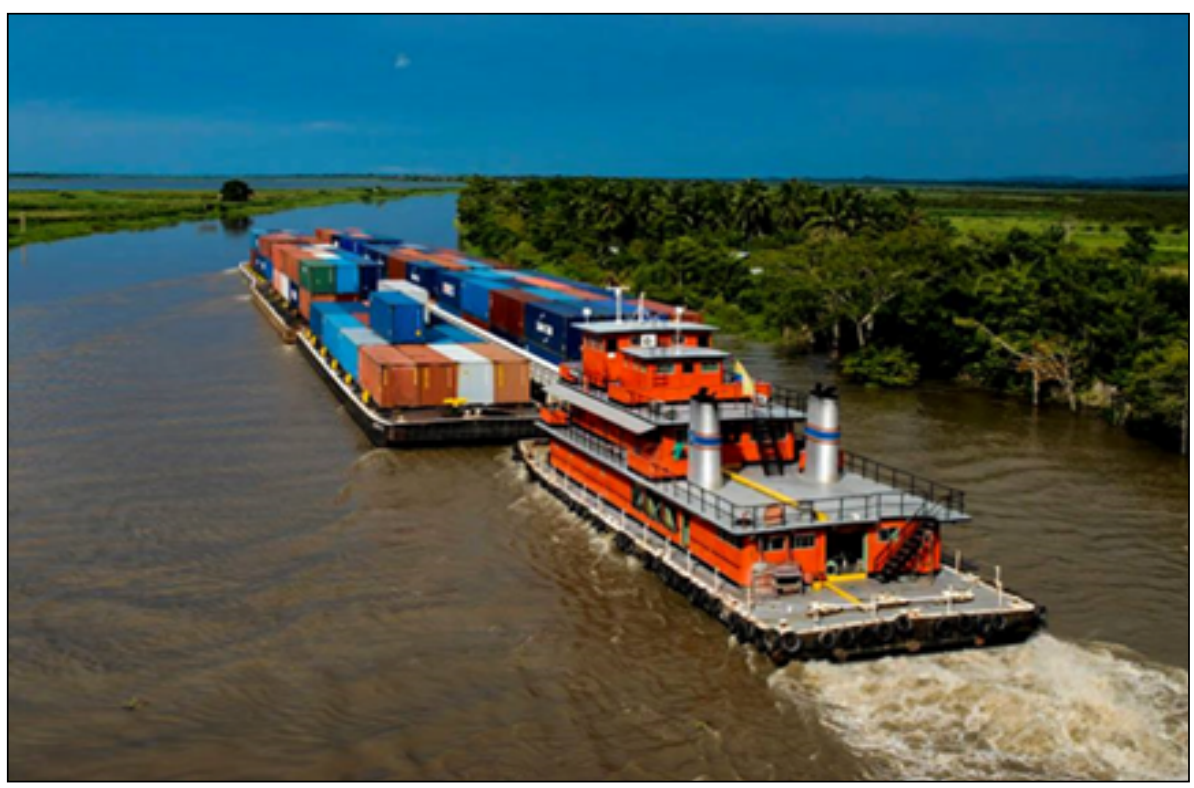

Fonte: RPNOTICIAS, 2019. 
Esse circuito fluvial é usado por embarcações de variados calibres que navegam fazendo a integração como outras regiões no território peruano, bem como para outros países da América do Sul, sobretudo Brasil e Colômbia que ocorre através do rio Ucayali, integrando o sistema hidrográfico do rio Amazonas, desde os tempos de exploração da borracha (século XIX até meados do século XX) tem possibilitado conexão fluvial do interior peruano com diversas cidades regionais como Iquitos (PE), Letícia (CO), Manaus (BR) e Belém (BR), situação que ainda se mantém na atualidade (conforme figuras 4 e 5 ).

Assim, Pucallpa é considerada a capital industrial na Amazônia peruana (Fig. 7). Corresponde a décima quarta cidade mais populosa da República do Peru, sendo considerada uma cidade-polo de toda a sua região e concentrando $60 \%$ do parque industrial peruano instalado na Amazônia. Esta condição foi reforçada pelo fato de ser uma zona franca com isenção de impostos para suas operações mercantis e industriais, $o$ que potencializou sua economia no setor do comércio, indústria madeireira e no turismo. Além disso, a região abriga sede de uma refinaria petrolífera próxima ao rio Pachitea, onde tem desenvolvido atividades de perfuração e exploração do petróleo e gás natural (Fig. 6). Tudo isso coloca a cidade como um ponto estratégico para integração econômica peruana, como também para os interesses internacionais (Kamp, 2002). 
Geografia, território e sociedade na Amazônia

Figura 6 - Refinaria de Petróleo em Ucayali.

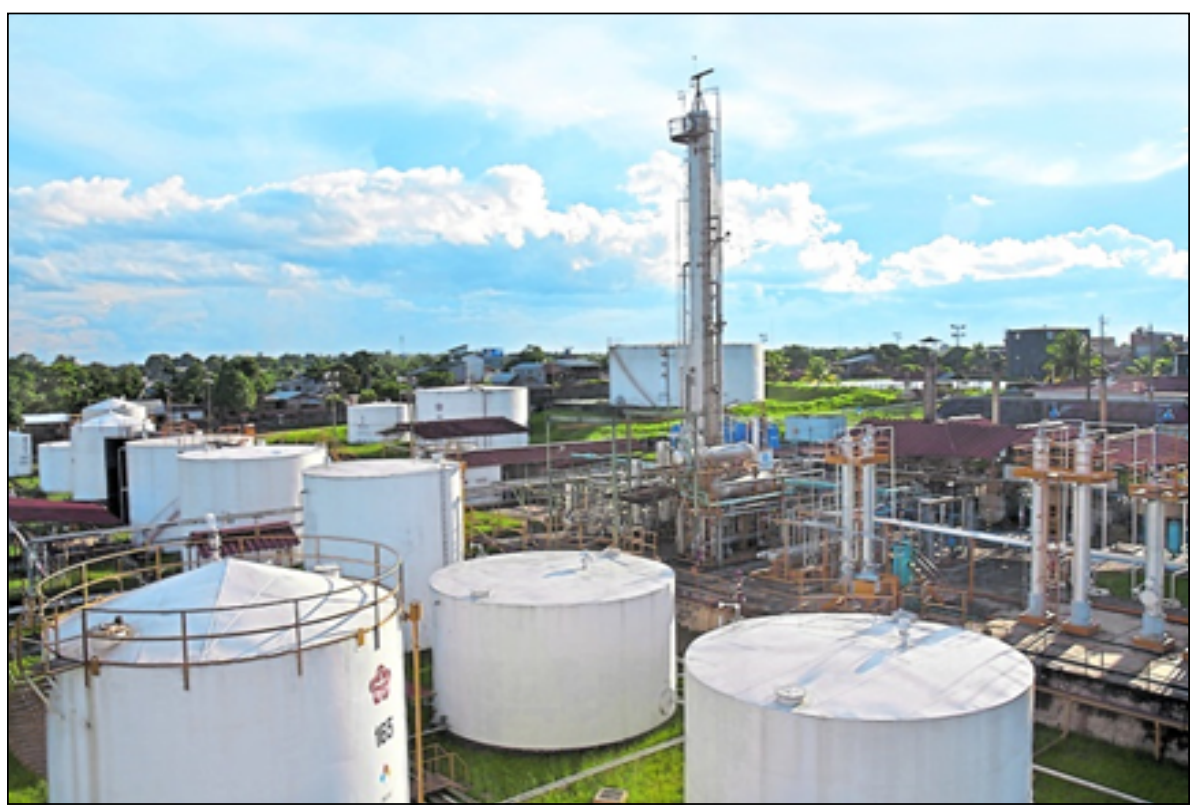

Fonte: Saldarriaga, 2018, p. 1.

Figura 7 - Praça central de Pucallpa.

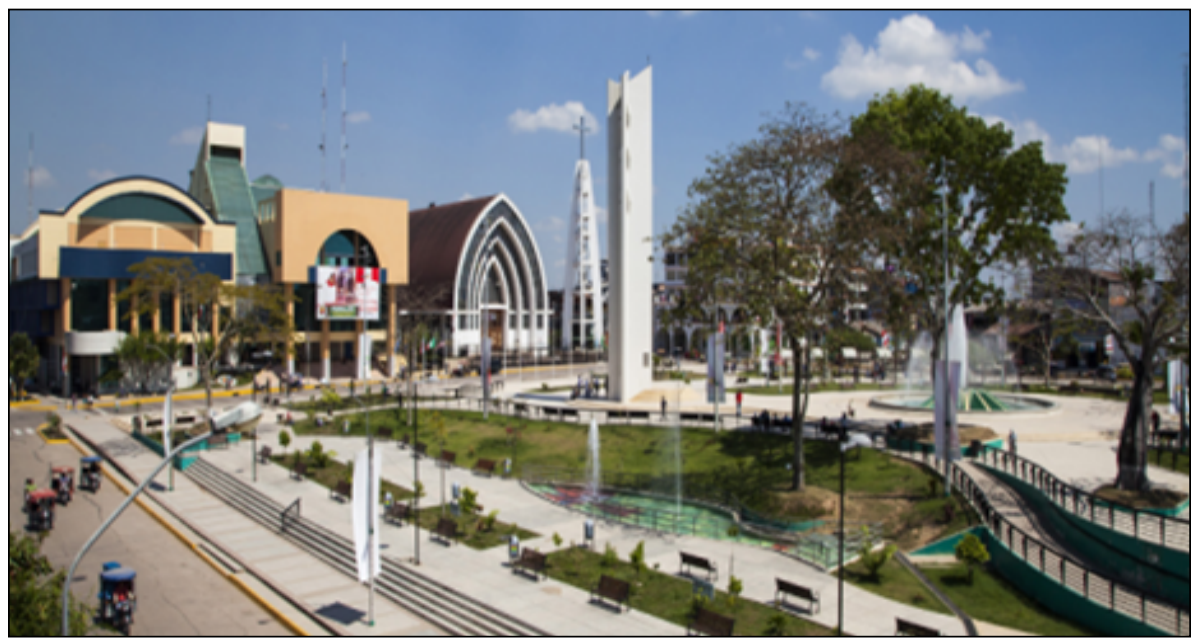

Fonte: Peru Inka Intertravel, 2017. 


\section{BR-364 - nos confins da fronteira oeste do Brasil}

Percebe-se que os meios e as vias de transportes fluviais na região, ainda representam formas de grande importância para os fluxos comerciais e sociais na Regional de Ucayali. A importância do rio está relacionada ao potencial de navegabilidade permanente, o que permitiu que a cidade de Pucallpa crescesse economicamente e se posicionasse como um importante centro urbano, comercial e industrial regional do leste peruano, dividindo com Iquitos (capital da Regional de Loreto e maior cidade amazônica do Peru) a condição centralizadora do desenvolvimento econômico nas regiões de selva deste país.

Finalizando, cabe ressaltar que Pucallpa se configura no principal centro de fluxos socioeconômicos fluviais e rodoviários de toda a Regional de Ucayalli. Internamente na Amazônia Peruana, sua maior integração se dá com Regional de Loreto (situado a jusante no plano hidroviário), com sua capital a cidade de Iquitos (ligada pelo rio Ucayali e por linha aérea). Cabe ressaltar que Iquitos possui o mais importante porto fluvial peruano, na integração com o sistema hidrográfico do Amazonas. Cabe ainda relembrar que há ainda, as ligações clandestinas entre as áreas polarizadas por Pucallpa com o oeste acreano, por onde se desenha a futura integração, conforme já apresentamos anteriormente.

\section{ESTADO DO ACRE: CRUZEIRO DO SUL, A CIDADE-POLO NO EXTREMO OCIDENTE BRASILEIRO}

O estado brasileiro do Acre, criado pela Lei Federal 4.070, em 15 de junho de 1962, tendo obtido a autonomia política por cinquenta e oito anos na condição de Território Federal (desde 1904). Localiza-se na região Norte, na porção mais ocidental do território nacional em plena área de floresta amazônica, formando uma extensa fronteira com a República da Bolívia e com a República do Peru. De acordo com o Instituto Brasileiro de Geografia e Estatística, (IBGE, 2019), possui uma população de aproximadamente 873.218 habitantes, estando subdivido em duas mesorregiões geográficas intituladas de Vale do Acre e Vale do Juruá que correspondem a parte leste e oeste do território acreano, respectivamente. Essa é a divisão atual, tendo sido elaborada pelo IBGE em 1989, sendo ainda subdividida em cinco microrregiões geográficas: de Rio Branco, de Cruzeiro do Sul, de Sena Madureira, de Brasiléia e de Tarauacá.

$\mathrm{Na}$ mesorregião do vale do Acre, localizam-se as microrregiões de Rio Branco, Sena Madureira e de Brasiléia. Corresponde à área mais povoada do Estado, onde residem aproximadamente $70 \%$ da população, 


\section{Geografia, território e sociedade na Amazônia}

além de concentrar as principais atividades de comércio industrial, serviços e agropecuária. A principal cidade de toda a mesorregião é a capital Rio Branco, no município de mesmo nome, sendo o mais populoso com aproximadamente de $48 \%$ da população estadual, isto é, aproximadamente 407.319 mil habitantes (IBGE, 2019).

$\mathrm{Na}$ mesorregião do Vale do Juruá, localizam-se as microrregiões geográficas de Cruzeiro do Sul e de Tarauacá. Destaca-se aí a cidade de Cruzeiro do Sul que é o segundo centro econômico acreano e o principal de todo o extremo sudoeste da Amazônia, sendo que o município tem a segunda maior concentração populacional do Acre, com cerca de 88.358 habitantes (IBGE, 2019). Destaca-se como o segundo polo econômico do Estado, dado que concentra uma vasta riqueza natural e, assim, polariza toda a mesorregião do Vale do Juruá, inclusive a porção Sudoeste amazonense. Então, além das cidades acreanas como Rodrigues Alves, Mâncio Lima, Porto Walter e Mal. Thaumaturgo, exerce liderança centralizadora também sobre algumas cidades amazonenses como Guajará, Ipixuna e Eirunepé.

Nesse contexto, Cruzeiro do Sul concentra diversas atividades econômicas e de serviços, abrigando a sede atacadista de empresas regionais (Figura 8 e 9). Essa é a principal característica que lhe confere a condição de polarizar e liderar as atividades econômicas, comércios, negócios, produção agropastoril, extrativista, educação e saúde, todavia também torna-se referencial de rotas de entrada de rede de narcotráfico. Tudo isso ainda tendo o rio Juruá como a principal via de fluxos, na região internamente (no Acre e sul do Amazonas) e, externamente, em especial com a cidade de Manaus (AM). Já no sentido de Rio Branco, com consolidação da BR-364, cada vez mais essa rodovia torna-se a principal rota integradora com o Centro-Sul brasileiro, para todo estado do Acre. 


\section{BR-364 - nos confins da fronteira oeste do Brasil}

Figura 8 - Centro da cidade de Cruzeiro do Sul.

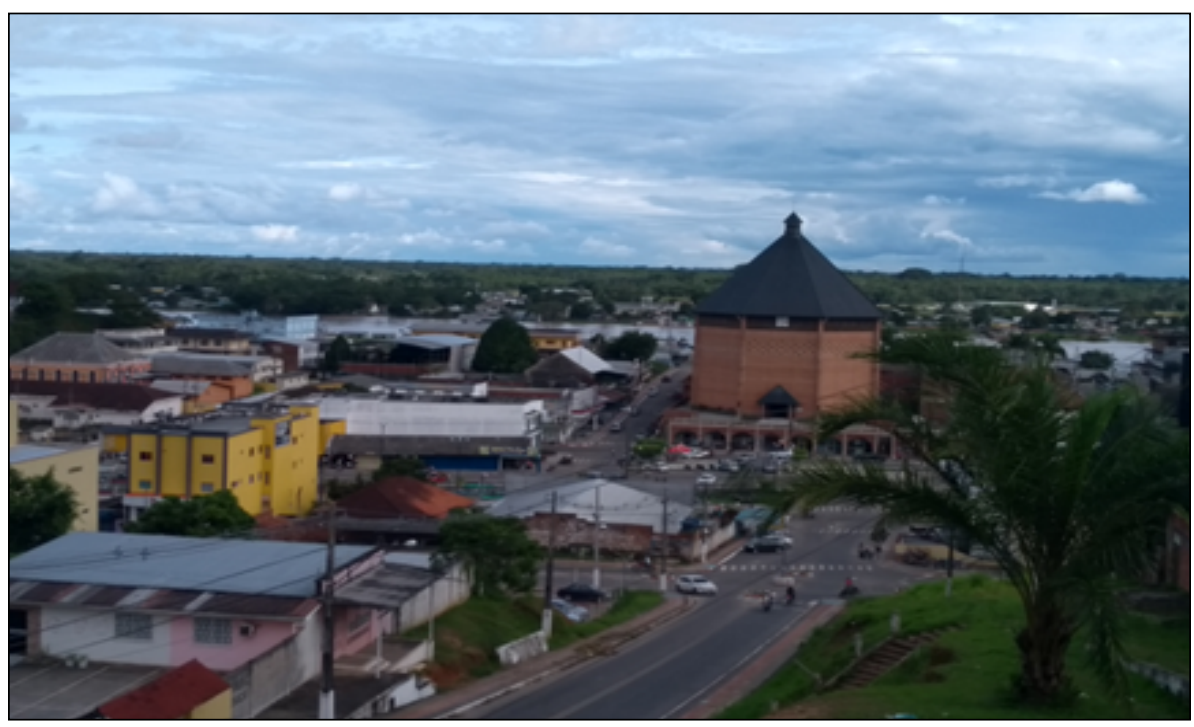

Fonte: Ednilson, 2019.

Figura 9 - Rio Juruá em Cruzeiro do Sul.

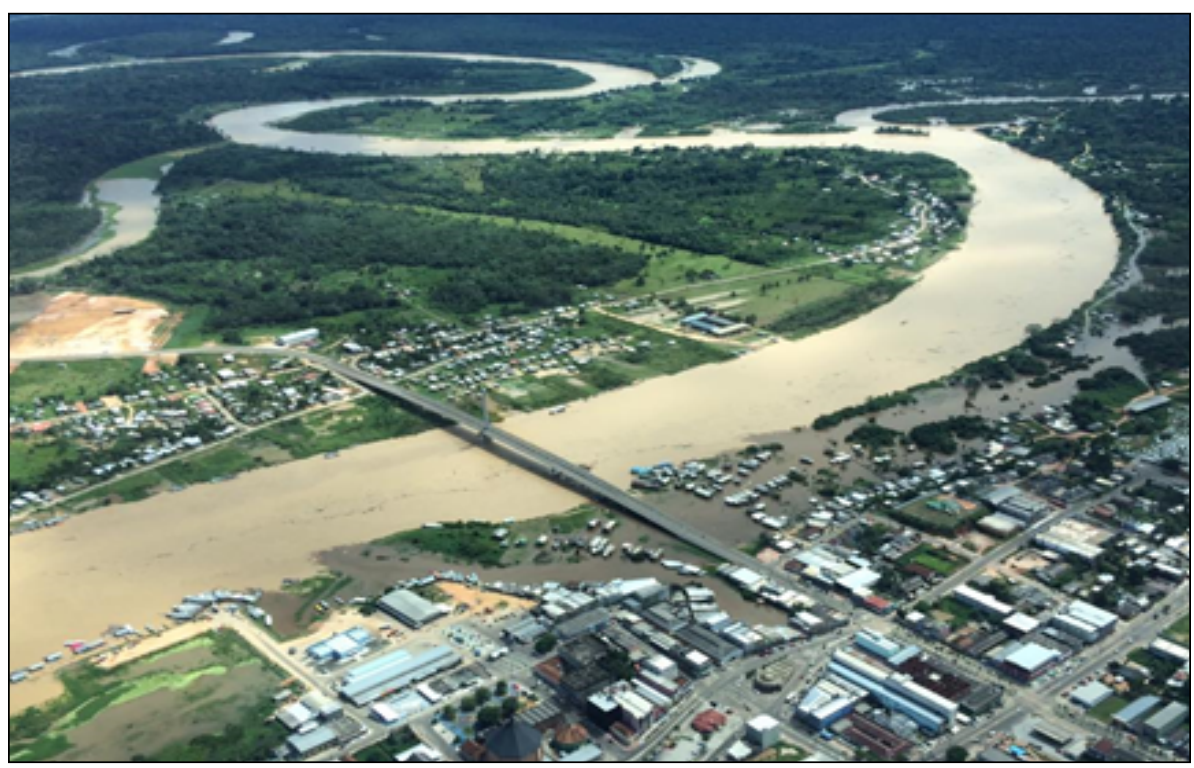

Fonte: AC24HORAS, 2017. 


\section{Geografia, território e sociedade na Amazônia}

A economia de Cruzeiro do Sul gira em torno comércio, extrativismo madeireiro, e agricultura. A atividade madeireira continua tendo uma constante expansão que, juntamente com a cultura de mandioca (Manihot esculenta) e a produção de farinha de mandioca, ocupam o título de principais produtos da economia regional. Cabe explicar que a farinha de mandioca de Cruzeiro do Sul é considerada uma das melhores da região Norte e muito apreciada em outras regiões do país, inclusive possuindo selo de indicação geográfica, pelo Instituto Nacional de Propriedade Industrial (INPI). É o primeiro produto agrícola no estado do Acre a receber essa certificação de qualidade e de indicação geográfica. Nos últimos anos, as atividades econômicas do município têm se direcionado para a expansão da pecuária bovina e da agricultura que visa produzir e comercializar em escala local, regional e nacional, destacando-se ainda o cultivo de produtos como o milho, feijão e guaraná.

Atualmente, com a pavimentação do trecho da rodovia federal BR-364 em direção a capital Rio Branco, as relações e os fluxos por meio fluvial se enfraqueceram, fazendo cada vez mais emergir uma nova dinâmica socioeconômica, voltada para a integração ao circuito terrestre da rodovia. Contudo, o rio Juruá ainda permanece como um enclave geográfico importante na região (cada vez mais perdendo os fluxos de mercadorias e pessoas, agora feitas pela rodovia), na sua ligação interna entre os municípios polarizados por Cruzeiro do Sul.

Cruzeiro do Sul, por ser principal cidade do extremo oeste da Amazônia ocidental brasileira, dispõe de um Aeroporto Internacional com capacidade de receber grandes aeronaves (Figura 10), sendo que no ano de 2017 recebeu uma média de 95.270 passageiros; 4.983 voos, sendo 3.111 domésticos e 943 executivas gerais, além movimentar $91.937 \mathrm{~kg}$ de carga aérea (Infraero, 2017). O aeroporto atende a aviação civil, comercial, turística e é base de apoio aos municípios vizinhos para deslocamentos em questões de atendimento médico, comércio e para as operações militares, sendo uma alternativa rápida de deslocamento. Atualmente, a cidade dispõe de um voo diário ofertado pela companhia Gol Linhas Aéreas, em avião comercial tipo Boeing 737 com destino a Rio Branco/Brasília e conexões nacionais e internacionais. Ademais, depois da hidrovia do Juruá, tem no transporte aéreo sua principal ligação com as outras cidades mais remotas do oeste do Acre (Porto Walter e Mal. Thaumaturgo). Dessas cidades menores, saem voos de aeronaves menores para Cruzeiro do Sul; e, daí é possível seguir para a capital, Rio Branco ou outros lugares a partir do voo diário que liga Cruzeiro do Sul à capital estadual. Assim, o aeroporto além de atender a aviação comercial é base de apoio aos municípios vizinhos, em transporte de maior rapidez. 


\section{BR-364 - nos confins da fronteira oeste do Brasil}

Durante muitos anos, o meio de transporte aéreo foi a única forma de locomoção no período de intensas chuvas, entre Cruzeiro do Sul e Rio Branco, devido à dificuldade de acesso pela rodovia (épocas antes da pavimentação). Com isso, a cidade tinha apenas duas alternativas para conexões socioeconômicas, sendo por via aérea para Rio Branco e transporte fluvial para Manaus, que historicamente foi o grande centro de toda a região Norte, desde os períodos áureos da extração da borracha, até a chegada das rodovias. No caso do transporte fluvial, no Acre, o sistema fluvial não possibilita a integração entre a parte leste e oeste do Estado, devido os rios terem seus fluxos definidos nos sentidos Sul e Norte, não se interligando em território acreano. Explicando melhor essa dificuldade, temos de ressaltar as características da geomorfologia fluvial dos rios que drenam o Acre. Esse sistema hidrográfico se faz num plano de "Sul para o Norte", ao passo que as terras que formam o Estado se estendem de "leste para o oeste". Devido a essa característica, a ligação por hidrovias sempre foi inviabilizada entre as cidades acreanas, situadas em duas bacias hidrográficas que não se integram entre si no território estadual: do rio Purus (na parte leste); e do rio Juruá (na parte oeste). Diante dessa a situação, a parte oeste acreana esteve, economicamente, até recentemente muito mais ligadas a Manaus (AM) de que à capital acreana.

Figura 10 - Aeroporto de Cruzeiro do Sul.

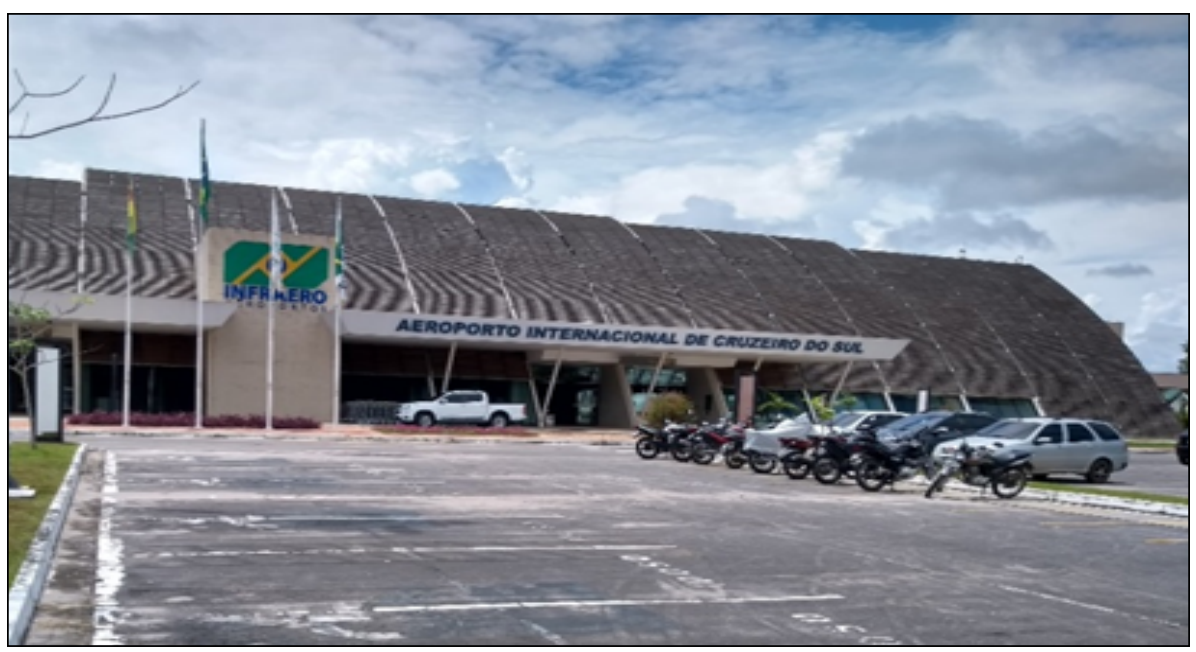

Fonte: Ednilson, 2019. 
Figura 11 - Porto Fluvial de Cruzeiro do Sul

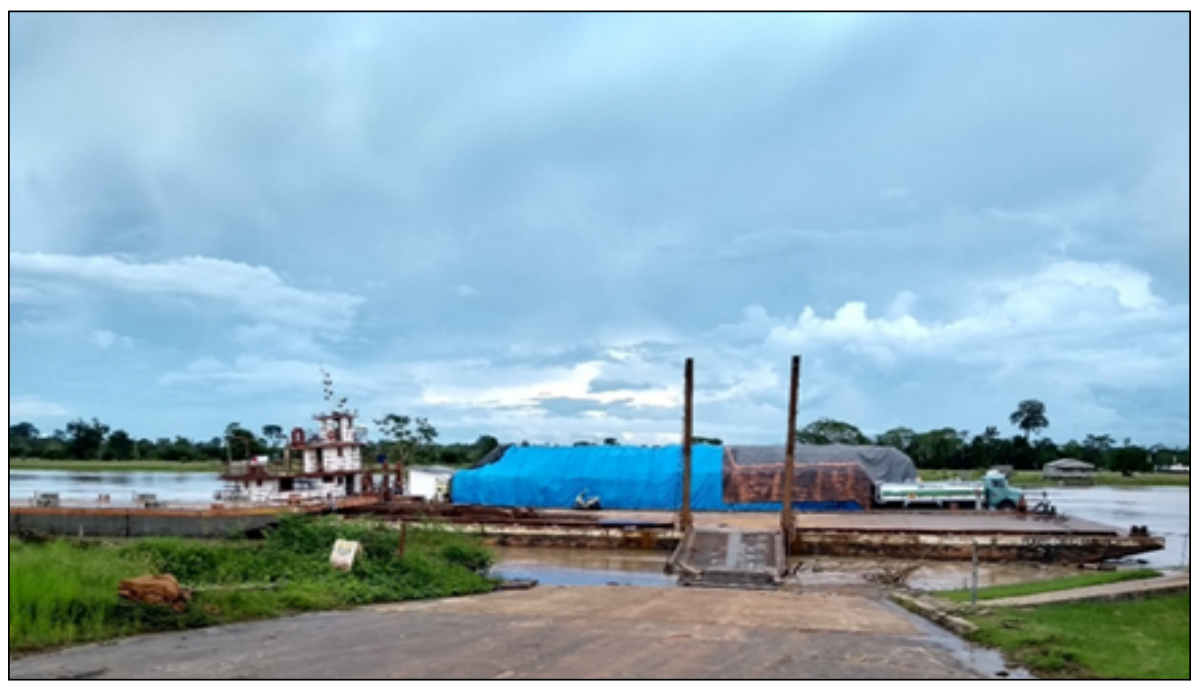

Fonte: Ednilson, 2019

Ademais, o porto fluvial da cidade Cruzeiro do Sul (Figura 11) tem capacidade parcial de receber embarcações cargueiras (balsas) de grande porte, sendo os melhores períodos entre os meses de outubro a junho que correspondem ao período chuvoso e que o rio Juruá estará com maior capacidade de navegabilidade. Porém, durante todo o ano, diversos barcos de pequenos e médios portes movimentam o porto, junto com as "balsas" que chegam de Manaus com produtos alimentícios, combustível e gás de cozinha em escala capaz de abastecer o comércio local.

Portanto, vimos que apesar de ter ocorrido a conclusão da pavimentação do trecho da BR-364 entre Rio Branco e Cruzeiro do Sul, a dinâmica fluvial na região permanece como alternativa de rota para o abastecimento. Diversos empresários que são proprietários de grandes embarcações (balsas) continuam preferindo trazer de Manaus suas mercadorias a serem comercializadas; sobretudo, porque a via fluvial ainda é menos onerosa que o transporte de mercadorias por via terrestre ou aérea, embora o tempo de deslocamento seja maior. Todavia, pode-se dizer que rio Juruá ainda permanece como a principal via aos fluxos econômicos por embarcações que se dirigem às cidades de Mal. Thaumaturgo e Porto Walter; cidade estas que até o presente não tem integração por rodovia consumada. 


\section{BR-364 - nos confins da fronteira oeste do Brasil}

O meio de transporte rodoviário é bastante utilizado e hoje é responsável por novas dinâmicas econômicas da região em direção ao Centro-Sul brasileiro. Assim, a cidade também dispõe de um terminal rodoviário com fluxo diário para as cidades acreanas de Rodrigues Alves e Mâncio Lima em ônibus e dispõem de uma rota para a cidade Amazonense de Guajará, distante apenas a $20 \mathrm{~km}$. O fluxo com mais intensidade se dá em direção a capital Rio Branco, numa rota segue pela BR-364, passando por várias cidades que estão nos trajetos da rodovia. De Rio Branco, pode-se ter acesso a viagens para outros lugares do país. Portanto, a BR-364 é uma importante via consolidada de integração de Cruzeiro do Sul, com os municípios a leste e com outros centros econômicos do país e da América do Sul. De forma geral, Cruzeiro do Sul ocupa a posição geográfica de um centro estratégico com agregação de três sistemas de transporte: fluvial, rodoviário e aéreo que se conectam entre si e são responsáveis por comandar as principais dinâmicas socioeconômicas locais. Porém, não há conexão para além da cidade, sendo ponto final da rota da BR-364. É diante disso que se almeja tanto a possível interligação com a região Peruana de Ucayali e sua capital Pucallpa como meta para superação dessa condição de ser "fim de linha".

\section{DAS INFORMALIDADES RELACIONAIS NA FRONTEIRA À CONSOLIDAÇÃO DA INTEGRAÇÃO FORMAL}

Como viemos tratando, a fronteira pan-amazônica entre Brasil e Peru, sobretudo entre a região oeste do estado do Acre com o Departamento de Ucayali se apresenta, hoje também, como um cenário de fluxos de atividades legais e ilegais. No que se refere à ilegalidade na fronteira, cabe ressaltar que a invasão de madeireiros peruanos em território brasileiro, também se dá em áreas de comunidades indígenas. Segundo Isaac Piyanko, diretor de uma associação indígenas no Rio Amônia (AC) há anos, madeireiros peruanos fazem exploração destes recursos em área onde vivem cerca de 500 índios do povo Ashaninka (Araújo, 2011). 
Geografia, território e sociedade na Amazônia

Figura 12 - Entorpecentes apreendidos em operação da Polícia Federal.

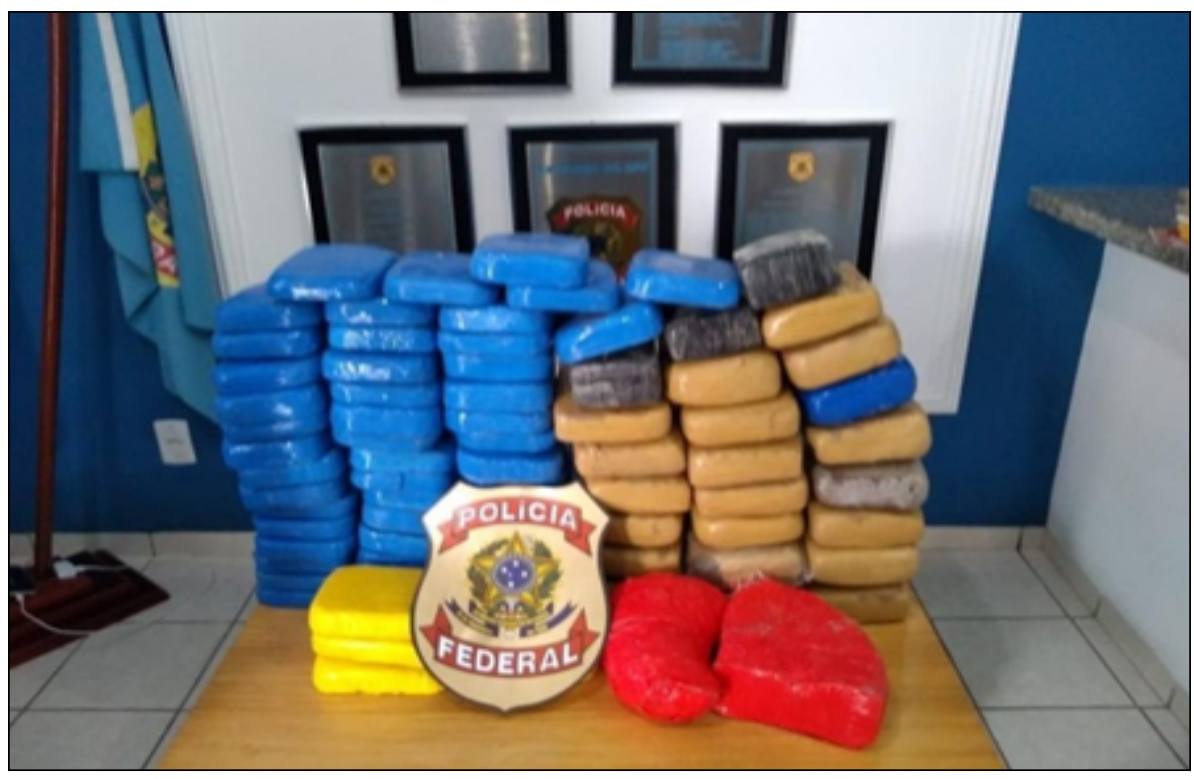

Fonte: Rogério, 2018.

Figura 13 - Tráfico internacional de madeira na Serra do Divisor, Acre.

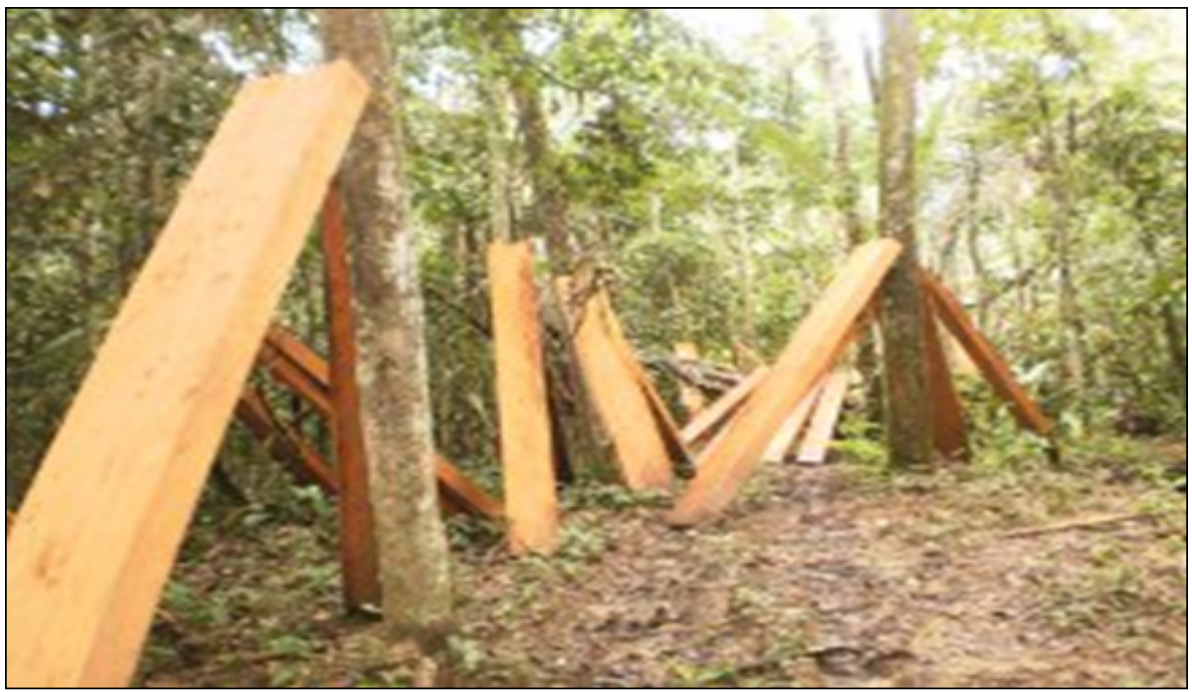

Fonte: ICMBio (2013). 


\section{BR-364 - nos confins da fronteira oeste do Brasil}

Referimos a ilegalidade especialmente no que se trata do tráfico internacional de drogas (fig. 12), por meios das bacias hidrográficas, trilhas e/ou estradas vicinais na floresta que articulam os fluxos dos dois países. Sendo assim, à falta de uma ligação formal por terra, cria-se um espaço propício para esta atividade com rotas mutáveis, no âmbito da articulação das bacias hidrográficas com trilhas na floresta (isto é, podem ser mudadas facilmente), o que dificulta as ações de policiamento, em especial no Brasil.

Além dessas contravenções de entorpecentes, há também grande quantidade de madeiras nobres como o Ipê, cedro, o Pau-ferro, o Jatobá, o Jacarandá, o Angelim que são extraídos ilegalmente das áreas de unidades de conservação brasileira, por contrabandistas madeireiros peruanos (Figura 13).

Dessa forma, nessa rota de fronteira, os rios são utilizados para formação de uma rede de transporte de fluxos ilegais que conecta às trilhas na floresta, desde o território peruano até as cidades acreanas de Cruzeiro do Sul, Mâncio Lima, Rodrigues Alves e Marechal Thaumaturgo. Daí, se poderão acessar as vias terrestres que complementam essa rede de circulação de tráfico internacional de drogas, via BR-364 com destino a Rio Branco e demais regiões do território brasileiro; ou ainda, por via fluvial com destino a Manaus e Belém. Muitas dessas rotas seguem destinos internacionais em direção a Europa e Estados Unidos.

A exploração da madeira sem autorização das autoridades competentes tem recrutado um elevado quantitativo número de pessoas, sobretudo pelo alto valor que é comercializado o produto. De qualquer forma, exploração da madeira ilegal também tem sido uma das atividades que tem dado vivacidade a região de fronteira, especialmente por ser bastante rentável economicamente, dado a ausência permanente de fiscalização de ambos os países. Assim, a linha da fronteira é praticamente como "terra sem lei", em que os madeireiros peruanos, fazem as derrubadas e chegam a montar vários acampamentos e abrem estradas clandestinas, ao longo da floresta, usando tranquilamente os rios para escoar as "toras de madeiras" (ICMBio, 2013, p. 1).

Para sair da ilegalidade e instaurar a legalidade, os governos do Acre e Ucayali, vêm discutindo a situação da região de fronteira com objetivo de combater essas práticas, tendo em vista que os fluxos informais estão cada vem mais se intensificando. Entretanto, tem sido uma tarefa bastante complexa pelo fato de não haver constantemente a presença dos órgãos de controle e fiscalização de ambos os países. Isto, ao 


\section{Geografia, território e sociedade na Amazônia}

passo que os criminosos estão sempre se reinventando, criando novas rotas terrestres e fluviais de difícil fiscalização para manter seus negócios. Isto, pois, tratando-se de uma borda de fronteira praticamente despovoada a ação dos narcotraficantes e madeireiros ilegais se torna mais fácil.

Tudo isto nos traz uma representatividade que a fronteira possui potencialidades para uma integração comercial, mas também a necessidade para sair da condição de terra de ilegalidades para um processo correto de desenvolvimento lícito para todos. De forma geral, as práticas ilegais, no momento, apenas reafirmam uma fronteira "viva", onde as relações internacionais já se materializam, mesmo inexistindo meios oficiais de deslocamentos rodoviários ou aéreos consolidados. Portanto, o projeto de uma possível integração entre Cruzeiro do Sul e Pucallpa por meio de uma rodovia, se mostra como um elemento geográfico que possibilitará transformações espaciais; e, por consequência o surgimento de um novo regionalismo na faixa de fronteira internacional do extremo oeste brasileiro, por meio dos fluxos formais legais existentes que irão fortalecer-se, ao passo que será possível a maior inibição àqueles que agem na contravenção e clandestinidade.

\section{CONSIDERAÇÕES FINAIS}

Ao analisar os impactos positivos para Cruzeiro do Sul e toda região oeste do Acre, percebe-se que, primeiramente, caso o projeto venha a se concretizar, trará uma nova rota terrestre mais curta na ligação do Acre com a cidade de Lima, que é um dos centros econômicos da América do Sul. Isso considerando que o estado do Acre se localiza a mais de 3.000 quilômetros das grandes metrópoles brasileiras e de todo o polo industrial. A proximidade com a metrópole peruana pode abrir mercado e maiores possibilidades ao desenvolvimento regional nessa porção do extremo oeste brasileiro. Assim, o Acre poderia exportar sua produção por duas vias terrestres internacionais com destino ao Peru, seja pela via da rodovia do Pacífico Rio Branco/Assis Brasil/Iñapari/Lima que está consolidado; e a segunda alternativa viria com a pavimentação do eixo terrestre Cruzeiro do Sul/Pucallpa e assim estabelecer uma nova rota terrestre internacional (que possivelmente, também poderá ser parte de complexo de vias de transporte como a ferrovia projetada).

Para que isso se concretize serão necessários acordos bilaterais entre ambos os países (Brasil e Peru); inclusive, que o Governo Federal 


\section{BR-364 - nos confins da fronteira oeste do Brasil}

do Brasil reconheça a necessidade e viabilidade econômica deste projeto para toda essa região do oeste acreano. Entretanto é preciso mais que isso; todavia, que ela seja avaliada como um projeto para a nação brasileira. Tratar como um projeto nacional significa reconhecer que essa nova rota de integração será a abertura de mais uma via do circuito intercontinental que se volta da costa do Oceano Pacífico, para a importação/exportação com Ásia e Oceania, inclusive, para países como China, Índia, Japão e Austrália, grandes mercados e parceiros comerciais para o Brasil.

Nesse contexto de integração e trocas comerciais, Pucallpa e toda a região de Ucayali se beneficiarão, pois abre também corredores de importação/exportação peruana ao mercado brasileiro. Internamente também amplia as possibilidades de estabelecer trocas comerciais com as cidades próximas e na rota fluvial do amazonas como Tabatinga (AM), Rio Branco (AC), Porto Velho (RO), Manaus (AM) e Belém (PA). Isso significa ao Brasil e ao Peru consolidar pontos de integração de outra rota comercial e social que articula do Atlântico ao Pacífico, tanto em direção à Europa, como Ásia, a África e Oceania.

Ademais, Cruzeiro do Sul e Pucallpa se consolidaram como centros estratégicos de passagem da grande produção brasileira e peruana; e, com isso também poderão ampliar os fluxos de pessoas e mercadorias e os possíveis investimentos contínuos na região. De certa forma, esses lugares deixarão de ser "fim de linhas terrestres" de seus países e passarão a ser pontos modais da integração bioceânica, como parte do grande projeto da Iniciativa de Integração Regional Sul-Americana (IIRSA).

Por final, pode-se compreender que as articulações institucionais em cursos para concretizar a integração terrestre evidencia a importância dessa via integradora entre as duas cidades. Isso virá com vista a melhor inserção social, econômica e política da região Amazônica na lógica globalizante que se impõem, no contexto internacional da América do Sul. Quem ganha? Quem perde? Dependerão dos acordos bilaterais que poderão ser trilhados entre os dois países e com outros entes da economia global. De fato, é notório que, para a região, ficará a saída do isolamento interno em território nacional e a abertura para uma economia mais internacionalizada. Então, formar-se-á mais um corredor que libera amplos potenciais de recursos ainda não explorados e abre condições para que ações informais, que até agora ocorrem, possam ser fiscalizadas, incentivadas ou inibidas. O resultado de tudo isso, certamente será novos caminhos que se abrem para o desenvolvimento da região. 


\section{Agradecimentos}

Agradeço ao Conselho Nacional de Desenvolvimento Científico e Tecnológico (CNPQ) pelo auxílio financeiro da bolsa de estudos que foi essencial durante todo o processo do mestrado, auxiliando na estadia, alimentação, transporte, aquisição de livros e materiais necessários aos estudos e pesquisa.

\section{REFERÊNCIAS}

AC24HORAS. Nível do Rio Juruá preocupa e órgãos discutem "pré-cheia”, em Cruzeiro. Jornal Ac24horas, Rio Branco, 12 dez. 2017. Disponível em: www.ac24horas.com/2017/12/12/nivel-do-rio-jurua-preocupa-e-orgaos-discutem-a-pre-cheia/. Acesso em: 23 mar. 2020.

AMAZONIA ALTERVISTA. Ucayali: tierra de leyendas. Pucallpa. 2020. Disponível em: www.amazonia.altervista.org/pucallpa/pucallpa pt.html. Acesso em: 27 mar. 2020.

ARAÚJO, G. Índios denunciam invasão de madeireiros peruanos no Acre. Rio Branco: GI noticiais, 2011. Disponível em: www.g1.globo. com/brasil/noticia/2011/08/indios-denunciam-invasao-de-madeireiros-peruanos-no-acre.html. Acesso em: 27 mar. 2020.

BECKER, B.K. O uso político do território: questões a partir de uma visão do terceiro mundo. In: BECKER, B.K; COSTA, R.H. (Orgs). Abordagens políticas da espacialidade. Rio de Janeiro: UFRJ, 1983, p. 1-21.

BECKER, B.K. Significância contemporânea da fronteira: uma interpretação geopolítica a partir da Amazônia brasileira. In: AUBERTIN, C (ed.). Fronteiras. Brasília: UnB; Paris: Orstom, 1988. p. 60-89.

BECKER, B.K. Amazônia: geopolítica na virada do III milênio. Rio de Janeiro: Garamond, 2006.

FÓRUM BINACIONAL. Fórum Binacional de Integração e cooperação para o desenvolvimento sustentável da região Ucayali - Peru e estado do Acre - Brasil. Documento de Instalação do Fórum Binacional. Cruzeiro do Sul/Acre - Brasil, julho de 2006. Disponível em: www.observatoriodafronteira.org.br/wp-content/uploads/2019/05/Documentode-Instala \% C2 \% BA \% C3\% BAo-F\% C2\% A6rum-de-Integra \% C2 \%BA\%C3\%BAo-Acre_Ucayali.pdf. Acesso em: 23 mar. 2020.

FÓRUM SOCIAL PANAMAZÔNICO. Intercâmbio de experiências Peru e Brasil 28 FOSPA abril em Tarapoto. 2017. Disponível em: www. forosocialpanamazonico.com/pt/intercambio-de-experiencias-peru-brasil-28-de-abril-en-fospa-de-tarapoto/. Acesso em: 23 mar. 2020. 
BR-364 - nos confins da fronteira oeste do Brasil

FÓRUM SOCIAL PANAMAZÔNICO. Intercâmbio de experiências Peru e Brasil 28 FOSPA abril em Tarapoto. 2017. Disponível em: www. forosocialpanamazonico.com/pt/intercambio-de-experiencias-peru-brasil-28-de-abril-en-fospa-de-tarapoto/. Acesso em: 23 mar. 2020.

GUIA GEOGRÁfICO. Mapas da América - Peru. Lima: Guia Geográfico, 2019. Disponível em: www.america-mapas.com/peru.htm. Acesso em: 5 abr. 2020.

IBGE. Acre população. Rio de Janeiro: IBGE, 2019. Disponível em: www.cidades.ibge.gov.br/brasil/ac/panorama. Acesso em: 19 out. 2019.

ICMBio. Madeireiros peruanos são detidos no Parque da Serra do Divisor. Brasília: Ministério do Meio Ambiente. 2013. Disponível em: www. icmbio.gov.br/portal/index.php?option=com_content \&view=article\&i$\mathrm{d}=3848 \&$ Itemid=999. Acesso em: 19 out. 2018.

INFRAERO. Aeroporto de Cruzeiro do Sul: características. Brasília: Infraero Aeroporto, 2017. Disponível em: www.infraero.gov.br/ aeroportos/aeroporto-internacional-cruzeiro-do-sul/sobre-o-aeroporto/ caracteristicas/. Acesso em: 19 out. 2018.

KAMP, R. Tão perto tão longe: o sudoeste da Amazônia. Rio de Janeiro: Summit, 2002.

MACHADO, L.O. Limites, fronteiras, redes. In: STROHAECKER, T.M. et al. (Org.). Fronteiras e espaço global. Porto Alegre: AGB-Porto Alegre, 1998.

MAIA, T. Deputado mostra que estrada ligando o Acre ao Peru pode levar aos EUA de carro. Jornal Juruá em Tempo, Cruzeiro do Sul, 4 set. 2019. Disponível em: www.juruaemtempo.com.br/deputado-mostra-que-estrada-ligando-o-acre-ao-peru-pode-levar-aos-eua-de-carro/. Acesso em: 18 nov. 2019.

PERU INKA INTERTRAVEL S.A.C. Pucallpa: Región Ucayali. 2017. Disponível em: www.peruinkaintertravel.com/region-ucayali/. Acesso em: 18 nov. 2019. 
ROGÉRIO, M. PF prende dois suspeitos de abandonar barco com mais de 80 quilos de droga no Rio Juruá. Cruzeiro do Sul, G1 AC, 2018. Disponível em: www.g1.globo.com/ac/cruzeiro-do-sul-regiao/noticia/ 2018/10/pf-prende-dois-suspeitos-de-abandonar-barco-com-mais-de-80quilos-de-droga-no-rio-jurua.ghtml. Acesso em: 19 out. 2018.

RPP NOTICIAS. ¿Qué es la Hidrovía Amazónica y por qué las comunidades nativas rechazan su construcción? Disponível em: www.rpp.pe/ peru/actualidad/hidrovia-amazonica-que-es-y-por-que-las-comunidades-nativas-rechazan-su-construccion-noticia-1207288. Acesso em: 11 out. 2019.

SALDARRIAGA, J.M. Petro-Perú: sí habrá combustible para Ucayali. Lima: El comércio, 2018. Disponível em: www.elcomercio.pe/economia/ dia-1/petro-peru-habra-combustible-ucayali-noticia-494838-noticia. Acesso em: 18 nov. 2019.

SILVA, E.G. Do rio à estrada: as transformações na configuração espacial da microrregião do Juruá acreano. Dissertação (Mestrado em Geografia) - Programa de Pós- Graduação Mestrado em Geografia-PPGG. Universidade Federal de Rondônia-UNIR, Porto Velho: PPGG/UNIR, 2020 .

STEIMAN, R. A geografia das cidades de fronteira: um estudo de caso de Tabatinga (Brasil) e Letícia (Colômbia). Dissertação (Mestrado em Geografia). Programa de Pós-Graduação em Geografia, Universidade Federal do Rio de Janeiro, Rio de Janeiro: PPGG/UFRJ, 2002. p. 117.

UCAYALLI (Gobierno Regional): Región de oportunidades! Pucallpa, 2019. Disponível em: www.regionucayali.gob.pe/. Acesso em: 26 mar. 2020.

\section{REFERÊNCIA COMPLEMENTAR}

ACRE (Estado). Governo do Estado do Acre. Secretaria de Estado de Meio Ambiente. Zoneamento ecológico-econômico do Acre: Fase II. Rio Branco: SEMA, 2006.

ACRE. Agência de notícias. Governo agiliza processos para implantação de voos comerciais entre Peru e Acre. Rio Branco: AC24horas. 2018. Disponível em: www.ac24horas.com/2018/03/22/governo-agiliza-pro- 


\section{BR-364 - nos confins da fronteira oeste do Brasil}

cessos-para-implantacao-de-voos-entre-peru-e-acre-ja-em-abril/. Acesso em: 3 abr. 2018.

IBGE. Sistemas de bibliotecas. Rio de Janeiro: IBGE, 2017. Disponível em: www.ibge.gov.br/. Acesso em: 3 abr. 2018.

SILVA, S.S. Das "microrregiões geográficas" às "regionais de desenvolvimentos": regionalizações das terras acreanas e as possibilidades de novos rearranjos no princípio do século XXI. NERA UNESP, v. 1, n. 2, p. 80-106, 2004. Disponível em: www2.fct.unesp.br/grupos/nera/ publicações/SilvioProd3.pdf. Acesso em: 19 out. 2018.

SILVA, S.S.; RODRIGUES, F.S.; ALMEIDA. L.F.; O desenvolvimento acreano em questão: contexto histórico e especificidades microrregionais. In: SILVA, S.S. Acre: uma visão temática de sua Geografia - Rio Branco: EdUFAC, 2008.

SILVA, S.S. Acre: uma visão temática de sua geografia. Rio Branco: EdUFAC, 2008. 


\section{TERRITÓRIOS PESQUEIROS NA AMAZÔNIA: DINÂMICA DE} PESCADORES COMERCIAIS E DE SUBSISTÊNCIA EM COMUNIDADE RIBEIRINHA DA TRÍPLICE FRONTEIRA COLÔMBIA-BRASIL-PERU ${ }^{1}$

Erlainy Joanna Souza de Paiva"

Ricardo Gilson da Costa Silva**

\section{INTRODUÇÃO}

No mundo amazônico, grande parte cercado por florestas, rios e terras férteis, comunidades ribeirinhas desenvolvem modos de vida distintos, marcados pela imprevisibilidade da natureza que rege suas atividades de trabalho. A pesca comercial crescente, sobretudo na região Norte do Brasil, trouxe possibilidades de trabalho e renda para diversas famílias ligadas às dinâmicas das águas. Contudo, tais atividades ampliam os impactos no meio natural quando ameaçam o equilíbrio da ictiofauna explorada.

$\mathrm{Na}$ Amazônia brasileira as atividades da pesca de subsistência e da pesca comercial em diversos ambientes aquáticos, sobretudo nos rios e lagos, são uma atividade extrativa que movimenta cerca de 285 milhões de dólares como renda bruta (Petrere, 1985). A economia da pesca no rio Solimões tem-se desenvolvido significativamente nos últimos anos (Moraes; Schor; Alves-Gomes, 2010a). A cidade de Manaus no estado do Amazonas concentra um dos maiores polos de comercia-

\footnotetext{
${ }^{1}$ Artigo publicado em: PAIVA, E. J. S. DE. SILVA, R. G. DA C. Territórios pesqueiros na Amazônia: dinâmica de pescadores comerciais e de subsistência em comunidade ribeirinha da tríplice fronteira Colômbia-Brasil-Peru. Revista Cerrados, v. 18, n. 2, p. 395-423, 13 nov. 2020.
}

" https://orcid.org/0000-0002-3348-9629 
lização pesqueira na região norte do Brasil, recebendo desembarque de pescado de diversos locais da região (Rufino, 2005).

Tradicionalmente, além de pertencer a uma das expressões identitárias das sociedades amazônicas, representa uma atividade comercial importante que cresceu razoavelmente nas últimas décadas. Analisar os territórios pesqueiros existentes na região Amazônica demanda estudos voltados, principalmente, às organizações sociais que se constituíram e continuam exercendo seus trabalhos com a pesca.

A cidade brasileira de Tabatinga (localizada no oeste do estado do Amazonas), situa-se na tríplice fronteira (Figura 1), onde se localizam as cidades de Letícia (Colômbia) e o distrito de Santa Rosa (Peru); são esses três núcleos urbanos que formam a tríplice fronteira. Evidentemente, o termo "Tríplice Fronteira" deriva da intersecção das fronteiras de três países diferentes. No total, o Brasil possui nove tríplices fronteiras, seguido de Peru e Colômbia com cinco cada um.

Tabatinga e Letícia são cidades gêmeas, unidas por fronteira seca e possuem comércio bastante interligado por essa proximidade terrestre. Diferentemente do que ocorre com o distrito peruano de Santa Rosa (conhecido localmente como "Isla de Santa Rosa"), localizada na margem direita do Solimões, é fronteira dividida pelo rio Solimões/Amazonas. A conexão entre Santa Rosa e as duas cidades faz-se por meio de transporte fluvial; dura em média 7 minutos o translado de canoa motorizada (motor 15hp), saindo do porto de Tabatinga ou Letícia. Como é dito na localidade "é só atravessar o rio".

Ambas estão localizadas na região do Alto Solimões/Amazonas, situadas praticamente no centro da grande floresta amazônica e compartilham, além de costumes, crenças, culinárias, cultura mesclada; o caudaloso rio Solimões, repleto de bens culturais materiais e imateriais que modelam a dinâmica vivida por pescadores, agricultores, comerciantes e indígenas das etnias Ticuna e Kambeba (também conhecidos por Omágua). Na parte oeste do município de Tabatinga está localizada a terra indígena Umariaçu, protegida pela Funai, que abriga índios da etnia Ticuna e Kambeba.

A população da tríplice fronteira tece sua vida ligada às águas brancas (barrentas) dos rios Solimões e Amazonas, rios nascidos nas Cordilheiras dos Andes e no Peru, que apresenta ao longo de sua extensão ambientes territorializados sobretudo por populações ribeirinhas e caboclas, realidade que se justifica pelas terras férteis de várzea e pela 
Geografia, território e sociedade na Amazônia

fartura presente nos rios que é suporte necessário à dieta alimentar dessas populações.

Figura 1 - Localização da tríplice fronteira entre Tabatinga (Brasil), Letícia (Colômbia) e Santa Rosa (Peru).

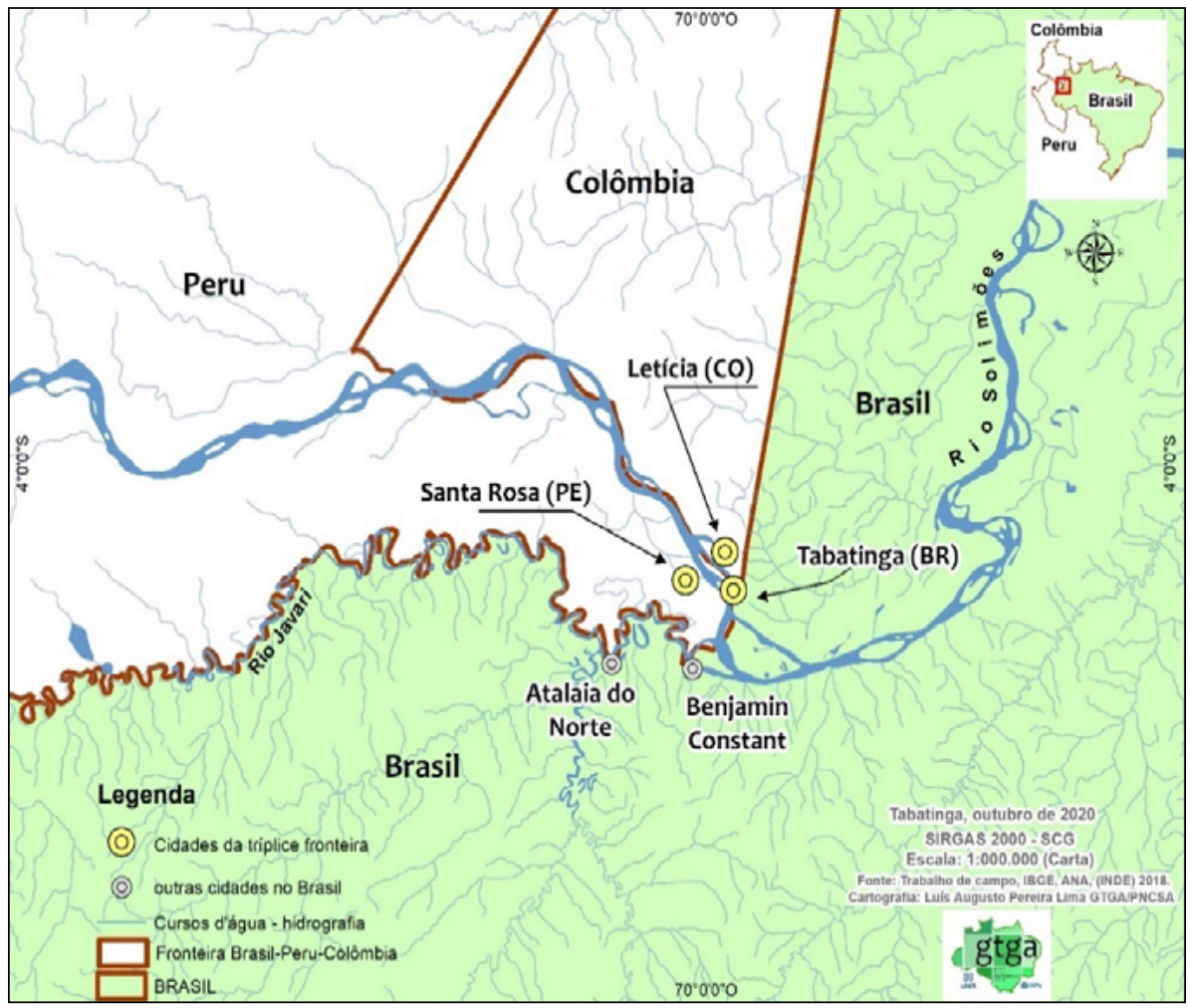

Fonte: Autores.

A região do Alto-Solimões, na qual se insere o município de Tabatinga (Figura 1), aparece como um dos principais referenciais de desenvolvimento da atividade pesqueira para fins comerciais (Provarzea, 2005). O território de pesca, por ser um espaço com fluidez (diferente dos espaços terrestres que são fixos), dado a vaga e imaginária demarcação territorial (não há barreiras físicas) que limita os ambientes aquáticos nesta área fronteiriça, vivencia disputas entre as modalidades de pesca comercial versus subsistência; comercial versus comercial, que, conse- 
quentemente, tem modificado a realidade dos pescadores e comunidades ribeirinhas que dependem diretamente desta atividade produtiva.

Nesses territórios, as comunidades locais são fornecedoras de pescados para os centros urbanos da região e, sobretudo, para o exterior (capital da Colômbia), tornando-se, assim, um dos principais polos do setor comercial da pesca regional (Moraes; Schor; Alves-Gomes, 2010, 2010; Moraes, 2012). Segundo Cruz (2007), a pesca no rio Solimões se intensificou devido à procura de bagres pelos grandes frigoríficos que estocam o pescado para exportação, sendo que esta espécie perfaz cerca de $95 \%$ da pescaria existente hoje na Amazônia brasileira, colombiana, peruana, boliviana e venezuelana.

A principal destinação dos bagres pescados no rio Solimões é a Colômbia, pois existe um tabu alimentar em torno do consumo de bagres pelos amazonenses (Barthem; Goulding, 1997). A cidade Letícia (Colômbia) é grande importadora de pescados oriundos de águas brasileiras, capturados por pescadores brasileiros, principalmente os peixes de couro (ou peixes lisos) como o surubim (Pseudoplatystoma fasciatum) e o mapará (Hypophthalmus spp), que possuem significativo valor comercial voltado para o abastecimento dos restaurantes locais que atendem turistas e demais consumidores da região (Paiva, 2018, 2019).

Por outro lado, além da pesca comercial gerar conflitos pela posse dos recursos pesqueiros, também possibilita, em uma segunda esfera, a exploração insustentável do ambiente com a realização contínua de capturas de pescados. Nesse sentido, alguns impactos ambientais locais se fazem sentir, como por exemplo, a diminuição dos estoques de peixes em espaços próprios à captura do pescado para subsistência familiar (Paiva, 2019). Essa é a realidade vivida pelos moradores da comunidade ribeirinha Terezina III desde a intensificação da pesca comercial após o fim do manejo pesqueiro no ano de 2018. A médio prazo, essa situação acarreta diversos problemas às comunidades locais, principalmente no que se refere ao campo de trabalho, à economia da pesca.

Assim, podemos dizer que o ser humano, como ser social, a pesca, como atividade de trabalho, e o território, como objeto de disputa, constituem elos que unem e, ao mesmo tempo, separam esses três países fronteiriços. Pela dinâmica que cerca as atividades de pesca, não podemos tomar como absoluto o cenário de hoje, tendo em vista as transformações que ocorrem em pouco espaço de tempo, contudo, podemos afirmar que este é o estado atual que se encontra esta área marcada por conflitos territoriais, desequilíbrio ambiental e exploração pesqueira. 


\section{Geografia, território e sociedade na Amazônia}

Nesse sentido, o objetivo deste artigo é contribuir para o conhecimento do modo de vida dos pescadores que habitam a comunidade ribeirinha Terezina III, localizada às margens do rio Solimões, na tríplice fronteira entre Brasil, Colômbia e Peru, especificamente na cidade brasileira de Tabatinga, com foco nos conflitos territoriais decorrente da economia pesqueira. Para isso, adotou-se os seguintes procedimentos metodológicos: trabalhos de campo realizados nas cidades de Tabatinga (Brasil) e Letícia (Colômbia), especialmente nos mercados de peixes das respectivas cidades; trabalho de campo realizado na comunidade ribeirinha Terezina III (Brasil); diálogos, entrevistas e registros fotográficos da paisagem local, das famílias e dos trabalhos comunitários com a pesca; revisão bibliográfica e documental inerente à temática.

De modo geral, o texto está estruturado, além desta introdução e das considerações finais, em três seções. Na primeira, problematiza-se o processo social a partir do conceito de territórios pesqueiros e comunidades ribeirinhas, os quais entende-se como mais adequados à orientação da pesquisa. Em seguida, analisa-se a economia da pesca na tríplice fronteira, destacando os atores, as principais espécies de peixes comercializadas e os dilemas para as comunidades ribeirinhas, para, na seção posterior, problematizar conflitos decorrentes das pressões nos territórios pesqueiros de Terezina III. Conclui-se o crescimento do comércio regional e internacional na tríplice fronteira amplia, sobremaneira, as pressões econômicas nos territórios tradicionais das comunidades ribeirinhas, de modo a exigir mais atenção do Estado, dado as características geográficas do extremo oeste brasileiro.

\section{TERRITÓRIOS PESQUEIROS E COMUNIDADES RIBEIRINHAS}

A expansão e a intensificação da pesca comercial, nos últimos 40 anos, acabaram por transformar a tecnologia empregada na pesca e na produção e, também, por mudar os tipos de produtos pesqueiros e as características do pescador comercial na Amazônia (Almeida, 2006; Moraes; Schor; Alves-Gomes, 2010; Silva, 2012; Paiva, 2018). Nesse sentido, podemos perceber que na Amazônia brasileira, mundialmente conhecida pela vasta diversidade ecossistêmica de fauna e flora, está em transformação o modo de exploração dos recursos pesqueiros, uma das atividades produtivas mais importantes para as comunidades ribeirinhas, cujo trabalho, renda e reprodução social, em boa parte, derivam da economia da pesca. 
Antes disso, compreende-se que os recursos pesqueiros "são todas as formas vivas que tenham na água o normal ou mais frequente meio de vida, juntamente com um definido interesse econômico" (Paiva, 2004, p. 1). Torna-se importante destacar as características básicas do recurso pesqueiro, não só como recurso natural renovável, como também sendo um recurso natural de propriedade comum e de livre acesso (Abdallah, 1998, p. 15), o que demanda políticas de gestão do território para conservar os recursos naturais e as atividades econômicas sustentáveis. Em relação aos recursos de propriedade comum, as instituições definem regras sobre quem tem acesso a um determinado recurso, o que e como pode ser explorado este recurso e quem participa nas decisões-chave sobre essas questões e sobre a transferência de direitos e deveres para com os outros (Paiva, 2004).

Entendemos como de livre acesso ao recurso pesqueiro encontrado na natureza, como os que estão presentes no rio Solimões, sujeitos a regulamentações estaduais e federais para uso e apropriação de vários grupos de usuários (pescadores comerciais, de subsistência, esportivos, etc.). Diferentemente ocorre com os recursos de acesso privado, como os cultivados em cativeiro, que não possuem regulamentação para que sejam explorados por diferentes grupos de usuários não reconhecidos como proprietários.

Pela dinamicidade dos pesqueiros em habitats "livres", como nos caudalosos rios Solimões e Amazonas, entende-se que estes recursos não reconhecem fronteiras. Contudo, o ser humano, como ser racional e político, sabe e reconhece os limites territoriais, mas, conforme verificado em trabalhos de campo, o crescimento da economia da pesca em lagos comunitários fechados, destinados à reprodução social das comunidades ribeirinhas, tende a prejudicar essas comunidades, ampliando a natureza dos conflitos territoriais.

Dessa forma, não há suficiente vigilância na fronteira, sendo um espaço de fluxo econômico que, por vezes, ignora os limites políticos do território nacional. Na hipótese de viverem somente em águas de domínio público, ou quando nestas se encontram os pescados, estes constituem recursos públicos, cuja exploração está sujeita às disposições do país que tem o domínio territorial dessas águas (Paiva, 2004). Essa característica do recurso pesqueiro, de ser um bem público, de propriedade comum e de livre acesso, pode implicar no advento da sobrepesca, propiciando a sua exaustão (Raggi Abdallah, 1998, p. 23). 


\section{Geografia, território e sociedade na Amazônia}

Em várias regiões de pesca na Amazônia, sobretudo nos rios do estado do Amazonas, tanto os pescadores profissionais quanto pescadores tradicionais das comunidades ribeirinhas vivenciam períodos de interrupção da atividade, o chamado período de defeso, que tem como objetivo garantir a reprodução de diversas espécies, sendo necessário a ação do Estado no regramento da atividade produtiva da pesca.

De igual importância, esse processo de interrupção, mesmo que por breve período de tempo, tem propiciado diversos conflitos na exploração dos recursos pesqueiros, disputados entre diversas categorias, das quais destacamos em Tabatinga: a) pescadores de subsistência; b) pescadores comerciais; c) pescadores comerciais e de subsistência (simultaneamente). Em tais situações, abre-se um debate referente aos significados da natureza e da vida comunitária em função das pressões econômicas por determinado recurso. Essa questão pode ser analisada a partir do conceito de território, que ajuda a compreender as tramas conflitivas que enredam os tensionamentos em comunidades ribeirinhas (Paiva, 2018 e 2019).

Nesse sentido, o debate nas ciências humanas referente aos conflitos socioambientais e/ou socioterritoriais tem na categoria território o caminho teórico para compreender as nuances dos processos políticos que atingem os espaços coletivos de comunidades tradicionais, a exemplo das comunidades ribeirinhas na Amazônia. Em Raffestin (1993), percebe-se o território como resultado de uma ação conduzida por um ator sintagmático (seja o Estado, empresas, movimentos sociais, organizações da sociedade civil, dentre outros), pois somente com a apropriação de um espaço concreto ou abstrato é que há territorialização, efetivação de um projeto de território. Quando um recurso da natureza se torna mais atrativo à economia, quase sempre a aceleração do processo produtivo leva a exaustão, o que pode resultar em conflitos diversos, dado a diversidade de atores que são mobilizados nesse processo.

Em Gottmann (1975), para além da dimensão política que o território assume na ação do Estado, dado o reconhecimento da teoria da soberania no âmbito das relações internacionais que estruturam o Estado-Nação, o território é tanto recurso quanto morada. Essa dupla dimensão implica reconhecer que as lógicas inerentes aos processos modeladores se diferenciam conforme as referências que os atores sociais, os atores sintagmáticos, têm para com o território. Para o capital e o Estado, o recurso assume a perspectiva econômica, enquanto que para as comunidades ribeirinhas é, sobretudo, morada, lugar do habitar, da copresença, do trabalho e da reprodução social, o que implica asso- 
ciar dimensões que integram tanto o trabalho quanto os direitos sociais, direitos humanos e territoriais (Costa Silva; Neves, 2018; Cunha; Costa Silva, 2019).

De tal modo, o território é um espaço onde ocorre delimitações políticas que implicam em manifestações do poder, que pode ou não gerar conflitos entre os atores que o vivenciam, ou que se apropriam subjetivamente e efetivamente desse espaço. A apropriação material e imaterial é ressaltada por Saquet (2007) e Haesbaert (2014), ao argumentarem que o universo social do território comporta elementos imateriais correlatos às condições de existências dos grupos sociais, sendo, portanto, condição política para viver e defender o espaço coletivamente apropriado.

O território pode ser aprendido, ao menos, em três processos socioespaciais, conforme síntese de Costa Silva e Neves (2018, p. 638): o território sempre é uma área apropriada e/ou dominada; sempre expressa projetos de usos e de construção de territorialidades; sempre é gestado por sujeitos, atores, agentes, instituições, de modo que não há território sem controle político. Por conseguinte, o território pesqueiro, utilizado especificamente por pescadores artesanais, demonstra a identidade do espaço vivido, as territorialidades das comunidades ribeirinhas em sua relação com a natureza, além de ser espaço constituinte de moradia e trabalho (Cunha; Costa Silva, 2019).

Esses grupos aparecem sob o conceito de "ribeirinhos", que segundo Diegues (1994) refere-se àqueles que andam pelos rios. O rio constitui a base de sobrevivência dos ribeirinhos, fonte de alimento e via de transporte, graças, sobretudo às terras mais férteis em suas margens. Já a ideia de comunidade aparece sob o prisma de vivência em coletividade, que algumas sociedades apresentam e tendem a ser reconhecidas como tradicionais. A construção do saber tradicional possui inúmeras distinções. É um saber alicerçado na vivência dos indivíduos, nas suas relações pessoais, sociais e, também, com a natureza. Pode-se afirmar que o conhecimento tradicional é fruto do trabalho e das descobertas de um grupo, o que justifica sua riqueza e diversidade (Diegues, 1994). Desse modo, portanto, este artigo dialoga com a vivência de diferentes categorias de pescadores em comunidades ribeirinhas, que ao tecerem suas dinâmicas de trabalho, estruturam todo o território, salientado pela conflituosa área na tríplice fronteira.

Nos estudos referentes às atividades pesqueiras, compreende-se que "o território pode ser visto ora conforme a lógica zonal, a partir 


\section{Geografia, território e sociedade na Amazônia}

do momento em que há a caracterização de zonas de pesca reconhecidas pelos pescadores, ora como uma lógica reticular, devido a extensa mobilidade que caracteriza a atividade pesqueira" (Silva, 2012, p. 29). Nesta concepção, os pescadores podem ser conhecidos e conceituados, segundo Ramalho (2016, p. 6), como profissionais que fazem da "pesca seus meios de vida" e são portadores de "um jeito de ser que é somente deles", um modo de vida pleno de especificidades socioculturais. O pescador é "o cara que sabe usar e desenvolver as pescarias", por conhecer e deter um ofício que é aprendido junto a seus familiares, porque "a pesca é uma profissão de família", uma atividade ancestral, comunitária; neste potencial:

O pescador é oportunidade socioeconômica, hábito de classe, costume, ideologia e relações sociais comunitárias ou com outros grupos, onde produz e reproduz sua singularidade em oposição ou em complementaridade com outros segmentos sociais no tempo e no espaço. Ademais, ser pescador é encontrar-se inserido em uma determinada relação na estrutura social, de comando do capital, cujas tensões alimentadas pelos desejos de autonomia, resignações e subordinações estão no dia a dia (Ramalho, 2016, p. 20).

Inerente aos espaços individuais (privado) ou coletivo (comunal ou grupal) onde são realizadas apropriações do recurso pesqueiro, não se deve pensar em delimitação espacial aleatória. Pode-se afirmar que os territórios pesqueiros, enquanto espaço de uso, foram formados a partir das relações sociais materializadas na delimitação territorial do recurso natural que assegura a economia da pesca. Assim, as ações de "apropriação" são importantes na produção do território, visto que são essas ações que passam a expor o espaço dominado por determinado grupo, na medida em que "isto transforma o território num trunfo particular como espaço político, campo de ação de diversas territorialidades, ação da população e apropriação dos recursos por essa população" (Silva, 2012, p. 19).

Num primeiro momento, o território tradicional pertence às comunidades ribeirinhas, sendo seu usufruto relacionado tanto ao trabalho quanto à reprodução social do grupo. Em seguida, no segundo momento, por seu recurso natural objeto da economia comercial, o território tradicional é disputado pelos agentes do comércio local e regional da pesca, de modo a causar os conflitos no uso do território. As lógicas políticas do território emergem desses processos conflitivos, ampliando a 
escala dos conflitos e os estranhamentos para com a natureza e o grupo social (Costa Silva, 2014; Rapozo, 2015).

Aos territórios de pesca ou pesqueiros são atribuídas relações de poder, isto é, podem possuir 'donos', ou famílias que são 'donas', sendo que várias famílias aparentadas podem utilizar do mesmo recurso pesqueiro, derivando muitas vezes em acordos entre familiares ou membros das comunidades (Ruffino, 2005, p. 18). Nesse caso, não pensamos no território apropriado de modo aleatório, mas sim, pela importância, representação, necessidade e, sobretudo, por ser produto de desejo social, caracterizado e territorializado a partir de seus usos e significações.

De modo geral, entende-se por comunidades ribeirinhas os grupos sociais que habitam próximos às margens dos rios e que "vivem basicamente em função da caça, pesca, agricultura e criação de animais de pequeno porte. Não são isoladas do restante do mundo, pois mantêm comunicações e relações diretas com centros urbanos e comunidades próximas" (Paiva, p. 45).

As condições sociogeográficas e culturais das comunidades ribeirinhas indicam que o universo social na região Amazônica é povoado por formas diferentes na relação com a natureza, de modo que as comunidades ribeirinhas constituem a síntese que o grupo humano produziu como condição necessária à existência neste mundo das águas e das florestas. $\mathrm{Na}$ relação das comunidades ribeirinhas é por demais sabido que o conhecimento popular compõe os alicerces que condicionam os grupos a viver, produzir e conhecer o meio geográfico, qualidade formada no processo histórico que qualificam a formação socioespacial da Amazônia brasileira (Scherer, 2004; Adams, 2006; Rapozo, 2015).

\section{ATIVIDADE PESQUEIRA NA TRÍPLICE FRONTEIRA}

Em 1768 o governo colonial deslocou um grupo de indígenas cristianizados para a localidade de Tabatinga, com o proposito comercial e político de erguer uma pequena feitoria (Machado, 1989). Em 1770 foi erguido o forte de São Francisco Xavier de Tabatinga, pelo Sargento-Mor Domingos Franco, com vistas a assegurar a posse do território as vésperas da assinatura do tratado de Santo Ildefonso (1777), o que veio a dar origem ao povoado (Rezende, 2006). Tabatinga foi considerada povoado em 1840. 


\section{Geografia, território e sociedade na Amazônia}

O município de Tabatinga está situado no interior do estado do Amazonas, possui $3.266,062 \mathrm{~km}^{2}$ de área territorial, assentada em uma planície fluvial com 73 metros de altitude e clima equatorial. Localiza-se na parte ocidental da Amazônia brasileira, margem esquerda do rio Solimões/Amazonas, especificamente na mesorregião do Sudoeste amazonense, microrregião do Alto Solimões. É um dos municípios do interior do Amazonas mais distantes da capital Manaus, com $1.106 \mathrm{~km}$ de distância em linha reta. Entre as duas cidades, o tempo médio de voo comercial (via empresa Azul) é de $1 \mathrm{~h} 55 \mathrm{~min}$, enquanto o transporte fluvial (barco, no trecho Manaus-Tabatinga) leva-se, aproximadamente, sete (7) dias.

Nos dados do último Censo Demográfico, Tabatinga apresentou 52.272 habitantes, com densidade demográfica de 16,21 hab/km². Ressalta-se as dificuldades socioeconômicas do município (em 2015, os alunos dos anos iniciais da rede pública da cidade tiveram nota média de 4.4 no IDEB), infraestrutura precária (com cerca $21.6 \%$ de domicílios com esgotamento sanitário adequado), serviços básicos, base produtiva, governança e governabilidade subdesenvolvidas, o que resultou no IDHM (Índice de Desenvolvimento Humano Municipal) de 0,616 (nível médio) no ano de 2010, influenciado, principalmente, pelo peso dos serviços públicos na composição do emprego e nos salários. O PIB per capita em 2017 foi de $\mathrm{R} \$ 7.255,96$, o que significa ocupar a $46^{\mathrm{a}}$ posição na escala estadual (IBGE, 2020).

Embora conte com a vigilância e prevenção das polícias civil, federal, militar e forças armadas, Tabatinga, sobretudo no ano de 2007, foi uma cidade marcada por muitos homicídios decorrentes do narcotráfico. Pela facilidade na entrada de entorpecentes oriundos de zonas produtoras do Peru e Colômbia, tornou-se uma das rotas principais do fluxo de drogas no Brasil. Nos dias atuais Tabatinga ainda é vista como local perigoso pelo alto índice de criminalidade e baixo desenvolvimento social. Somente em 2017, foram 22 homicídios registrados na cidade. Nos últimos 5 anos, a quantidade de roubos dobrou, saltando de $51 \mathrm{em}$ 2013 para 103 em 2017 em Tabatinga. Os furtos também aumentaram de 68 casos em 2013 para 139 em 2017.

O Atlas da Violência - Retrato dos Municípios Brasileiros 2019, elaborado em parceria com o Fórum Brasileiro de Segurança Pública, mostra que houve um crescimento das mortes nas regiões Norte e Nordeste influenciado, principalmente, pela guerra do narcotráfico, a rota do fluxo das drogas e o mercado ilícito de madeira e mogno nas zonas rurais. 
A cidade tabatinguense apresenta intenso comércio pesqueiro no mercado municipal local, fruto da produção advinda de pescadores comerciais de pequena escala e de pescadores de subsistência, que comercializam pequenas quantidades de excedentes. Ambos vivem em Tabatinga ou nas comunidades ribeirinhas próximas. A livre comercialização entre Tabatinga e Letícia facilitada pela ausência ou pouca fiscalização de órgãos de controle como a Agência Nacional de Vigilância Sanitária (Anvisa), Ibama e Polícia Federal, faz com que a compra e venda de pescados entre as duas cidades se torne um comércio fora da legalidade. O comércio pesqueiro é impulsionado pelo "livre" fluxo econômico na tríplice fronteira, onde os três países dividem as águas do rio Solimões e nele desenvolvem, há bastante tempo, a pesca.

Segundo as pesquisas que realizamos para a elaboração deste artigo, no ano de 2019 em Tabatinga, o modo alimentar da população local é pautado no consumo de proteínas como pescados da própria região (Gráfico 1) e carne bovina, suína e frango congelado que vem da capital Manaus. Segundo Barthem e Goulding (1997), as taxas de consumo de pescado na Amazônia são as maiores do mundo, com média estimada em $369 \mathrm{~g} /$ pessoa/dia ou $135 \mathrm{~kg} / \mathrm{ano}$ em certas áreas do alto Solimões e alto Amazonas, constituindo-se na principal fonte de proteínas para as populações humanas residentes.

Ainda segundo as pesquisas, o peixe aparece como principal fonte de proteína consumida na tríplice fronteira. A pesca de subsistência apresenta maior diversidade de capturas na época de cheia e vazante do que nas épocas de seca e enchente, devido a maior disponibilidade de hábitats para os peixes que passam a explorar as matas alagadas. Já a pesca comercial tem o pico de produção no primeiro semestre do ano, geralmente entre os meses de abril e junho, período de enchente-cheia, coincidente com a migração de algumas espécies de characiformes, como jaraquis, matrinxã, pacus e curimatã (Freitas; Rivas, 2006).

Através da pesquisa de campo, realizada no primeiro semestre de 2019 (período de enchente-cheia), no mercado municipal de Tabatinga, foram entrevistadas vinte (20) pessoas de cada categoria (vendedor e consumidor), totalizando 40 entrevistados no geral. Dentre os 40 entrevistados, temos brasileiros, colombianos e peruanos que compram/vendem peixes no mercado municipal de Tabatinga por ser mais barato. 
Unimos as três nacionalidades e dividimos somente em dois grupos: consumidor e comerciante, para facilitar o uso dos dados.

Gráfico 1 - Espécies de peixes mais consumidos e comercializados por colombianos, peruanos e brasileiros da tríplice fronteira (2019).

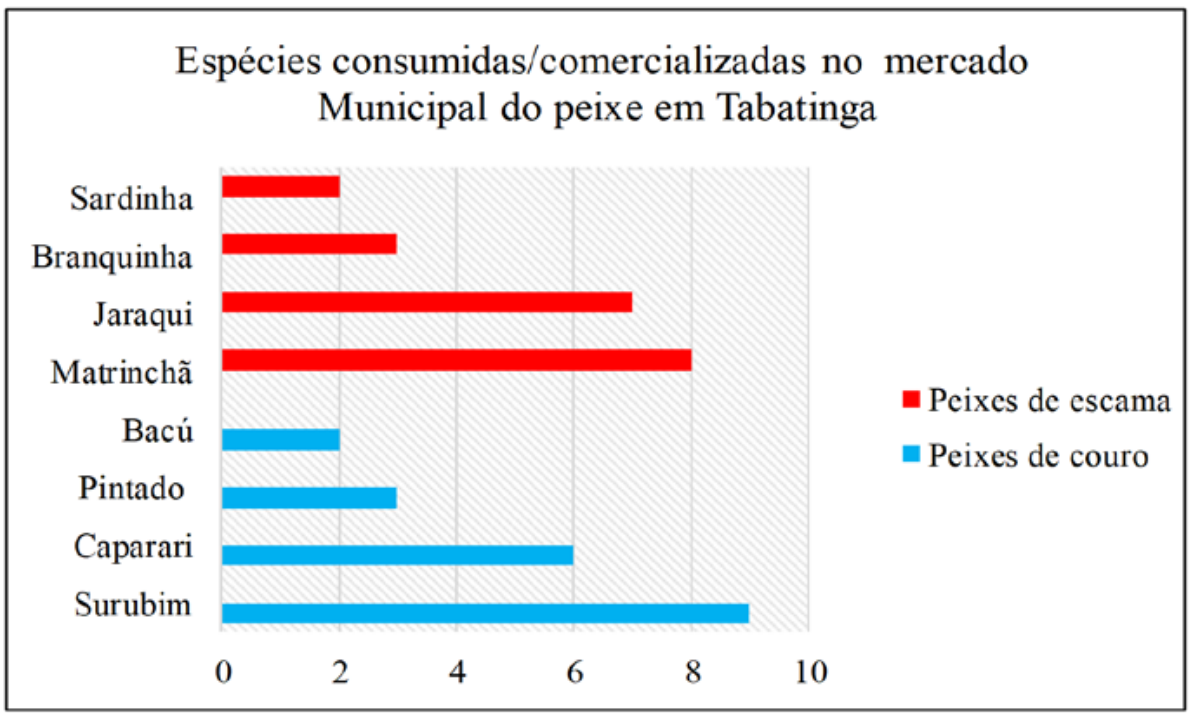

Fonte: Pesquisa de campo, maio de 2019.

É preciso salientar que no mercado municipal do peixe em Tabatinga a venda do pescado não é realizada somente por brasileiros. Colombianos e peruanos também comercializam seu produto lá. Em outros pontos da cidade tabatinguense também podemos observar essa prática comercial, sobretudo na conhecida "feira do bagaço" (local para venda de frutas, verduras e legumes) em que a maioria dos comerciantes são peruanos.

Aos entrevistados da pesquisa foi feita a seguinte pergunta: quais espécies de peixes de escama e de couro que você mais compra/vende? Através das respostas, constatamos as espécies que aparecem com maior percentual de venda e consumo na tríplice fronteira são respectivamente: surubim, matrinxã, jaraqui e caparari (Gráfico 1). Observa-se que, em uma escala de 0 a 10 , os peixes mais comercializados e consumidos, 
segundo sua classificação, são: surubim (peixe de couro) e matrinxã (peixe de escama).

$\mathrm{Na}$ época da pesquisa o surubim estava fora do período de defeso que ocorre entre novembro e março. Essa espécie de couro aparece com porcentagem significativa no comercio e consumo local devido ao agradável sabor e ser de médio porte. Segundo Freitas e Rivas (2006, p. 4), siluriformes de médio e grande porte como dourada, piraíba, surubim, caparari e pirarara tem maior parte da captura exportada para outros estados brasileiros e para o exterior. $\mathrm{O}$ tabu alimentar em torno do seu consumo entre a população amazonense faz com que apenas uma pequena parte desses peixes, geralmente surubins, siga para o comércio local, enquanto a maior parte é destinada à exportação, situação que configura uma estrutura de mercado mais complexa (Barthem; Goulding, 1997).

Espécies escamosas, como a matrinxã, alimentam-se de frutinhas, sementes, insetos e pequenos peixes. Esses são os principais motivos que os tornam muito consumidos por tabatinguenses, por serem considerados "limpos" devido sua alimentação. Diferentemente das espécies de couro, que são conhecidas regionalmente por "urubu dos rios" porque são carnívoros e, segundo alguns mitos, alimentam-se de cadáveres que são jogados no rio Solimões. Isso significa que para os tabatinguenses é preferível consumir espécies escamosas (cultura alimentar). Já os colombianos e peruanos não tem essa crença e os consomem sem distinção, aliás, para eles é preferível espécies de couro por não conter quase espinhas.

A pesca excessiva realizada na região, voltada a abastecer o comércio nacional e internacional, tem ocasionado sérios problemas ambientais, sobretudo nos ecossistemas de lagos, que sofrem ações degradantes de pescadores comerciais, que visam espécies endêmicas (como pirarucu e tambaqui, que se reproduzem em lagos). Essa realidade tem ocasionado a inserção de medidas conservacionistas, como o manejo pesqueiro em lagos comunitários, por exemplo, criado para reestruturar ambientes afetados pelo desenvolvimento da pesca insustentável.

Com o intuito de amenizar os impactos gerados pela exploração, foram criados diversos órgãos governamentais que passaram a ser responsáveis por questões voltadas à conservação do ambiente pesqueiro. É necessário estabelecer, antes de tudo, que os rios e lagos federais são aqueles que: se estendem por mais de um Estado, fazem fronteira com países vizinhos, se estendem por países vizinhos ou estão no interior 


\section{Geografia, território e sociedade na Amazônia}

de imóveis federais ou sobre a faixa de $150 \mathrm{~km}$ das fronteiras do país (Schwade, 2019, p. 111).

Assim, ficou a cargo do Instituto Brasileiro do Meio Ambiente e dos Recursos Naturais Renováveis, Ibama (órgão federal responsável pelas políticas de proteção do meio ambiente no Brasil), o controle e fiscalização das medidas estabelecidas pela política de ordenamento pesqueiro. O objetivo dessa ação é fazer com que os recursos naturais pesqueiros sejam explorados racionalmente, de acordo com as normas e regulamentações estabelecidas para manter sua sustentabilidade (Abdallah, 1998).

A descentralização e compartilhamento entre o Ibama (que tem o poder de fiscalização e ordenamento) e comunidades ribeirinhas (principais afetados) trouxeram melhorias para a inserção de medidas voltadas aos cuidados e proteção dos ambientes degradados, como ocorreu no manejo pesqueiro desenvolvido na comunidade Terezina III. Essas ações resultaram na aproximação entre o Ibama e comunidades ribeirinhas. Consequentemente, tornou-se possível criar instruções normativas, gestão participativa e acordos de pesca como meio de gerir os recursos pesqueiros, contando com a participação dos usuários e do Estado, quando o projeto IARA (Instituto Amazônico de Manejo Sustentável dos Recursos Ambientais) passou a assumir tal atividade, por intermédio da parceria que já desenvolvia com o Ibama, desde 1994.

A tomada de decisão conjunta entre o poder público (órgãos ambientais) e os usuários (pescadores e moradores de comunidades ribeirinhas) foi uma forma de melhoria no controle e fiscalização dos recursos, tendo em vista a grande extensão do espaço amazônico. A descentralização do poder de decisão garantiu maior participação dos moradores da Comunidade Terezina III, que passaram a ter "voz" para discutir sobre a realidade vivida, como também para apontar os fatores geradores de conflitos entre os pescadores de subsistência da comunidade, pescadores comerciais internos e externos. Assim, inicia-se um ponto de conflito pelo uso do território pesqueiro, uma vez que este passou a ser controlado e a ter restrições para o desenvolvimento da pesca comercial no lago comunitário.

O lago comunitário Caiau (Figura 2), localizado no território da Comunidade Terezina III, muito utilizado e de grande importância 


\section{Territórios pesqueiros na Amazônia}

para as populações locais pela riqueza ictiológica, aparece como principal espaço de conflito entre as categorias de pescadores comerciais e de subsistência, uma vez que ele é disputado pelos recursos que nele existe, e não somente pela área que ocupa.

Figura 2 - Localização do Lago Caiau e as comunidades brasileiras próximas à Tríplice Fronteira (2019).

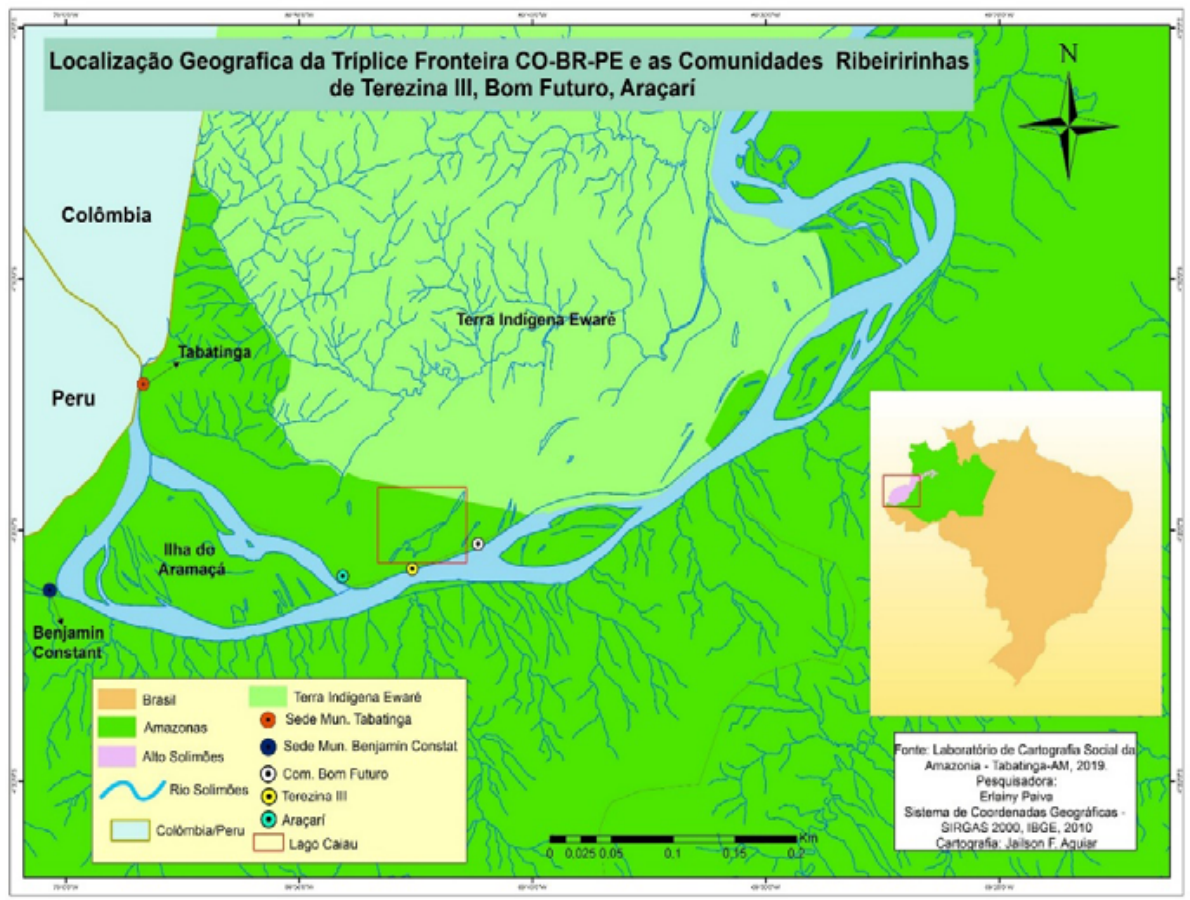

Fonte: Núcleo de Estudos Socioambientais da Amazônia (Nesam), 2019.

O que mais tem gerado alvoroço entre os comunitários é a questão dos conflitos ocorridos com a presença de pescadores comerciais do Peru e da Colômbia, de modo que se torna mais difícil realizar mediações e restrições de acesso ao lago, porque esses agentes dificilmente aceitam regras e respeitam limites territoriais.

$\mathrm{Na}$ região transfronteiriça, os conflitos entre pescadores das três nacionalidades se tornaram recorrentes, principalmente pela facilidade que a "fronteira molhada" oferece em decorrência da falta/pouca fiscalização pública. A intensa exploração pesqueira ocorrida nessa área de 
fronteira é potencializada pelo mercado consumidor regional e internacional, pois, além de abastecer os consumidores locais, grande parte dos peixes de couro capturados em águas brasileiras é destinado à exportação para a capital colombiana, Bogotá. Segundo Paiva (2019), o fluxo internacional de pescado (peixes de couro) representa $70 \%$ do comércio em Tabatinga, enquanto o consumo local responde por 30\% da produção.

As principais espécies destinadas à comercialização internacional têm características peculiares: são peixes de couro e de grande porte como o surubim (Pseudoplatystoma corruscans) (Figura 3). Quase não há dados/informações de exportação de peixes escamosos para a cidade de Bogotá. Segundo os entrevistados, os peixes "miúdos” e de escamas possuem melhor comercialização no mercado local de Tabatinga.

Figura 3 - Comércio de peixe nos mercados de Letícia (Colômbia) e Tabatinga (Brasil).
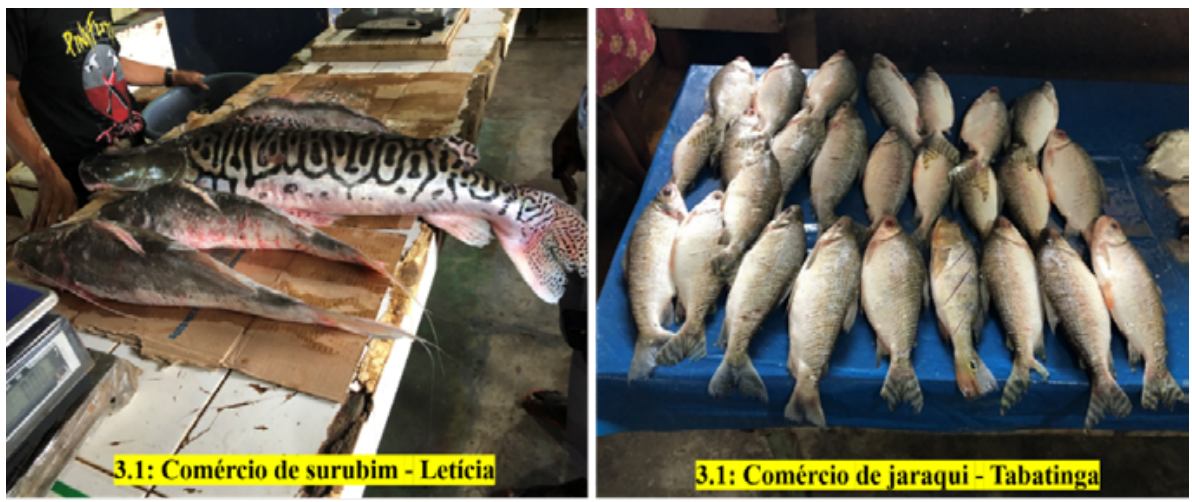

Fonte: Pesquisa de campo, 2019.

Assim, salienta-se que a comercialização pesqueira regional e internacional possuem identidade quanto as espécies que o mercado consumidor tem preferência, assim, os pescadores procuram capturar espécies destinadas a cada um desses mercados, de modo que, logo após a captura, o peixe basicamente tem "destino certo", como podemos identificar no diálogo de muitos pescadores: "quando pegamos um surubim, na certa já sabemos que vamos vender em Letícia, porque lá compram rápido, ou vender para algum frigorífico" (Entrevistado 1). 
A cadeia produtiva dos bagres conta com a participação de vários agentes que intermedeiam o processo. Em Tabatinga, a proximidade com o destino simplifica essa cadeia, permitindo que os próprios pescadores artesanais comercializem diretamente o seu pescado para as bodegas de Letícia (Moraes et al., 2010).

Grande parte do pescado que chega à mesa do consumidor local é oriunda da atividade realizada por pescadores comerciais (a pesca para esses tem finalidade principalmente profissional) e por aqueles que vendem os excedentes (para esses a pesca não é uma profissão). Esses sujeitos vivem em comunidades ribeirinhas, ou na cidade de Tabatinga. Muitos pescadores que vão ao mercado da cidade vender os excedentes, não detêm grandes quantidades a ofertar, mas a venda colabora para o sustento das famílias e evita o desperdício do pescado.

Não há presença significativa de indústrias ou embarcações (com capacidade para armazenar mais de 1 tonelada) que realizam a atividade pesqueira na cidade de Tabatinga ou próxima a ela. Normalmente, as pescarias são realizadas por pescadores dos três países, em embarcações com motores a diesel e caixas de gelo que podem conservar até $500 \mathrm{~kg}$ de pescado por viagem. Os frutos da pesca são escoados nos mercados municipais de Letícia, Tabatinga, e uma parcela significativa, sobretudo os grandes bagres, é destinada ao mercado consumidor de Bogotá, através dos frigoríficos colombianos localizados em Leticia.

O mercado dos bagres possui lógica internacional para o Alto e Médio Solimões embora existam registros de mercado para esses peixes em Manaus que, entretanto, participa de outra rede que não a da exportação para Letícia (Moraes et al., 2010). A produção do entorno de Tabatinga e Benjamim Constant é transportada em canoas dos próprios pescadores ou, no caso de Benjamim Constant, os "patrões" (donos das bodegas de Letícia com os quais os pescadores têm contrato) enviam embarcações para recolher o pescado nos frigoríficos locais (Moraes et al., 2010).

A complexidade que envolve os estudos acerca da geografia econômica da pesca na Amazônia fica evidente quando se consideram os valores que o peixe pode assumir tanto como produto de consumo quanto como mercadoria .Verifica-se que a produção pesqueira na tríplice fronteira se enquadra na perspectiva do circuito inferior da economia urbana proposta por Santos (1979), sendo, pois, uma economia que expande os trabalhos formal e informal, articulando o espaço ribeirinho com o espaço urbano da tríplice fronteira, o que resulta num dos prin- 


\section{Geografia, território e sociedade na Amazônia}

cipais ramos econômicos que envolve milhares de trabalhadores rurais que podem, assim, acessar uma renda para suas famílias. Caracteriza-se, sobretudo, pela escala local e regional dos fluxos mercantis do pescado, no qual, como bem expressou Gottmann (1975) e Santos (2000), o território apresenta-se tanto como recursos quanto como morada para os atores que participam da economia da pesca nesta região da Amazônia brasileira.

Sendo, pois, territórios pesqueiros, a dinâmica socioeconômica engendra os conflitos pelos recursos pesqueiros e pelo controle do território, dado a escala produtiva cada vez demandada pelo mercado regional, o que tende a modificar as relações sociais que congregam o território. Assim, os conflitos e os estranhamentos nas comunidades ribeirinhas se instalam em função das variáveis externas que passam a influenciar e impactar o vivido territorial.

\section{OS CONFLITOS PELO USO DO TERRITÓRIO NA COMUNIDADE TEREZINA III}

A comunidade ribeirinha Terezina III está localizada a 23,672km de distância em linha reta de Tabatinga, margem esquerda seguindo o fluxo do rio Solimões/Amazonas. Para chegar à comunidade gasta-se em média $2 \mathrm{~h} 30 \mathrm{~min}$, no motor de $15 \mathrm{hp}$, saindo do porto de Tabatinga (somente se chega a ela utilizando transporte fluvial). Terezina III possui 151 habitantes (crianças, jovens, adultos e idosos) divididos em 51 famílias, que possuem representação religiosa católica, com apenas uma igreja na localidade. Há uma única escola chamada "Padre Anchieta", localizada na entrada da comunidade e atende séries do ensino primário, fundamental e médio.

Não há hospital ou unidade básica de saúde, somente há presença de dois agentes de saúde que realizam atendimentos básicos. Ao acontecer problemas de saúde graves, os pacientes são encaminhados para Tabatinga em um motor potente de $200 \mathrm{hp}$, destinado a atender casos graves e urgentes. Por estar em área de planície sujeita a inundações anuais durante o período da enchente que expande o rio Solimões/ Amazonas, Terezina III passa a ter dois períodos distintos: cheia e seca (vazante), que interferem na produção agrícola e pesqueira local. As principais fontes de renda das famílias podem ser agrupadas em: pesca, agricultura, criação de animais de pequeno porte, extrativismo vegetal, emprego público, aposentados do INSS, beneficiários do bolsa família e 
seguro defeso. Para eles, a agricultura e a pesca são os principais meios de trabalho e renda.

Na comunidade está localizado o lago Caiau, de uso comum dos moradores de Terezina III, Araçari e Bom Futuro, que são próximas territorialmente. Contudo, há denúncias de que o lago também é utilizado por sujeitos alheios, sejam estes pescadores colombianos e peruanos. Tal fato fez com que as comunidades estabelecessem desde o ano de 2007 um acordo de pesca e, consequentemente, passaram a manejar o lago em 2015. Em 2017 o manejo fracassou e voltaram a realizar as mesmas práticas de exploração que levaram a diminuição dos estoques pesqueiros. Intensificou-se a partir daí conflitos entre os diferentes grupos de usuários.

A emergência de conflitos socioambientais decorrentes das atividades econômicas está frequentemente presente em qualquer território inserido em sociedades produtivistas e consumistas. Tais conflitos, contudo, podem ser compreendidos em inúmeras formas. Por exemplo, podemos analisá-los a partir das contradições existentes do comércio desigual e injusto entre países do atual capitalismo globalizado (Porto, 2020, p. 11), ou da fragilidade institucional em regiões de fronteira, como se verifica na Amazônia (Paiva, 2018, 2019), sendo este último, o ponto de análise neste artigo.

Por existirem numerosos pescadores e comunidades ribeirinhas na região estudada, e pela intensa atividade comercial realizada pelos mesmos, são originados conflitos pelo uso do território e pela posse dos recursos naturais existentes nesses territórios (Rapozo, 2015). Sabe-se que espécies altamente lucrativas, como o Pirarucu (Arapaima gigas), são excessivamente procuradas e capturadas, e quando se reconhece que espécies como essas habitam ambientes singulares, como os lagos, esses espaços passam a ser o foco principal de atividades predadoras que buscam altos lucros, como atualmente ocorre no lago Caiau.

A realização de pescarias manifestamente insustentáveis nesses ambientes singulares que abrigam espécies muito procuradas, são, hoje, palco de conflitos. Normalmente, os conflitos ocorrem pelas "regras" e "recursos lucrativos" que os espaços demarcados possuem. A quebra de regras firmadas em acordos de pesca, por pessoas da comunidade ou de fora, são entendidas como ameaças graves que ferem os direitos de quem é usuário e depende dos recursos naturais afetados. Há, assim, alguns tipos de conflitos comuns no ambiente aquático de acesso restrito às comunidades ribeirinhas, como ocorre no lago Caiau, envolvendo dife- 


\section{Geografia, território e sociedade na Amazônia}

rentes atores, causas e consequência, as quais estão sistematizadas no Quadro 1.

Para entendermos os atores que participam do conflito representado no Quadro 1, as causas e consequências, partimos da compreensão do primeiro grupo formado por "pescadores de subsistência”. Esses são os indivíduos que pescam principalmente para comer, vez ou outra vendem os excedentes, mas para eles a pesca não é uma profissão. Esse grupo é formado majoritariamente por pessoas mais idosas que não tiveram o hábito de comercializar.

O segundo grupo é composto pelo "pescador comercial interno". Esses indivíduos realizam a pesca comercial tanto em lagos comunitários (essa categoria tem permissão para pescar nos ambientes de acesso restrito à comunidade em que vive, justamente por ser morador dela), como em outros ambientes de livre acesso (rio Solimões, por exemplo). Esses pescam principalmente para vender, consomem apenas uma pequena parcela daquilo que produzem. Para eles a pesca é uma profissão.

Quadro 1 - Conflitos existentes em lagos comunitários de acesso restrito (lago Caiau).

\begin{tabular}{|c|c|c|}
\hline Atores do conflito & Causas & Consequências \\
\hline $\begin{array}{c}\text { Pescador comercial } \\
\text { interno }\end{array}$ & $\begin{array}{c}\text { pescarias em ambientes } \\
\text { de uso compartilhado } \\
\text { desrespeito aos acordos }\end{array}$ & $\begin{array}{c}\text { Discussões verbais, } \\
\text { denúncias e promessas } \\
\text { de agressóes físicas }\end{array}$ \\
\hline $\begin{array}{c}\text { Pescador de subsistência } \\
\mathrm{x}\end{array}$ & $\begin{array}{c}\text { Invasão das áreas } \\
\text { delimitadas; pesca ilegal } \\
\text { externo }\end{array}$ & $\begin{array}{c}\text { Ameaças de pescadores } \\
\text { externos; medo por parte } \\
\text { dos pescadores de } \\
\text { subsistência }\end{array}$ \\
\hline $\begin{array}{c}\text { Pescador comercial } \\
\text { interno }\end{array}$ & Disputa pelos territórios \\
de pesca & $\begin{array}{c}\text { Discussões verbais, brigas } \\
\text { e ameaças de morte }\end{array}$ \\
$\begin{array}{c}\text { Pescador comercial } \\
\text { externo }\end{array}$ & & \\
\hline
\end{tabular}

Fonte: Pesquisa de campo, 2019. 
Diferentemente do terceiro grupo, formado por "pescadores comerciais externos". Esses não estão autorizados a pescar em ambientes de acesso restrito às comunidades, visto que, não tem direitos de utilizar esses espaços por ser "alheio" a ele. Os ambientes de livre acesso seriam essencialmente seus territórios permitidos (rios). Esses são pescadores tabatinguenses, peruanos e colombianos que desrespeitam locais delimitados em busca de boas capturas.

As causas dos conflitos costumeiramente ocorrem pelo desrespeito mútuo entre pescadores do grupo 2 e 3 , o que interfere no uso de territórios restritos e na quebra dos acordos de pesca. O não reconhecimento ou negação existencial dos territórios pesqueiros levam à invasão desses ambientes pela "ultrapassagem do território alheio", o que origina as consequências listadas no Quadro 1. Embora o Sindicato de Pescadores, Colônias de Pesca e os próprios sujeitos estabeleçam "acordos de pesca" com o objetivo de não gerar conflitos, ou mesmo abrandá-los, estes, continuamente, não são cumpridos e dão efeito contrário à conciliação.

Os mais afetados são os pescadores de subsistência, pois para estes, o lago é visto como uma "geladeira" que guarda o alimento diário. A interferência de invasores lhes dá sensação de ser saqueado na própria casa. Os pescadores de subsistência de Terezina III não têm costume e condições de migrar para pescar em outras áreas (longa distância e cansaço físico). Assim, para estes, o desequilíbrio e conflito causado nos lagos não é visto, a princípio, como perda comercial e sim de sobrevivência, afeto, pertencimento. Os outros dois grupos são atingidos, sobretudo, comercialmente (não negamos que pode haver o sentimento de afeto e pertencimento com o lago). Para eles a solução é buscar alternativas (percorrer áreas mais distantes, aumento de combustível e gelo para armazenagem, mais horas de trabalho e longe de casa) que certamente requerem mudanças significativas na rotina de trabalho.

Pelas disputas recorrentes, o aumento do quantitativo pescado se torna evidente, visto que uma categoria quer se "sobressair" ao capturar mais peixes que a outra e obter mais lucro ao comercializar. Esse aumento na captura passa a ser um dos principais motivos intensificadores da pesca predatória em lagos comunitários, principalmente, em função da ação dos pescadores comerciais internos e externos, enquanto os 
de subsistência são os mais impactados por essas ações continuamente exploratórias.

Os conflitos apresentados possuem temporalidade que margeia ao menos três décadas, mas com alta intensidade nos últimos dez anos pela imposição do capital sobre as comunidades ribeirinhas de pescadores. Nisso, os dados do quadro anterior foram elaborados a partir do roteiro de identificação dos conflitos entre os três grupos na comunidade. Assim, foram apresentadas as categorias e tipos de conflitos mais citados pelas comunidades estudadas. A participação da comunidade foi importante para compreensão da realidade, embora alguns apresentassem receio em comentar sobre o assunto, a maioria não teve dificuldade em dialogar e fornecer informações. A maior parcela desses conflitos, embora pretéritos, ainda possuem consequências destruidoras.

Nesse contexto, um fator importante analisado em comunidades ribeirinhas é o significado cultural e de identidade na relação ribeirinha: a pesca. O hábito de possuir apetrechos, arrumar a canoa e sair para pescar são ações cotidianas que intimamente manifestam identidade e caracterizam a vida cultural do pescador ribeirinho. Esses indivíduos, então, passam a viver sob dimensões sociais de espaços em que as crenças, mitos, sonhos e realidades dão sentido para a produção e reprodução da condição de ser "pescador". Portanto, todas as influências contraproducentes que modificam o espaço vivido e interferem na dinâmica diária dos grupos sociais são ações que fragilizam o modo de vida dessas comunidades (Figura 4). 


\section{Territórios pesqueiros na Amazônia}

Figura 4 - Famílias de pescadores comerciais chegando ao porto de Tabatinga (2019).

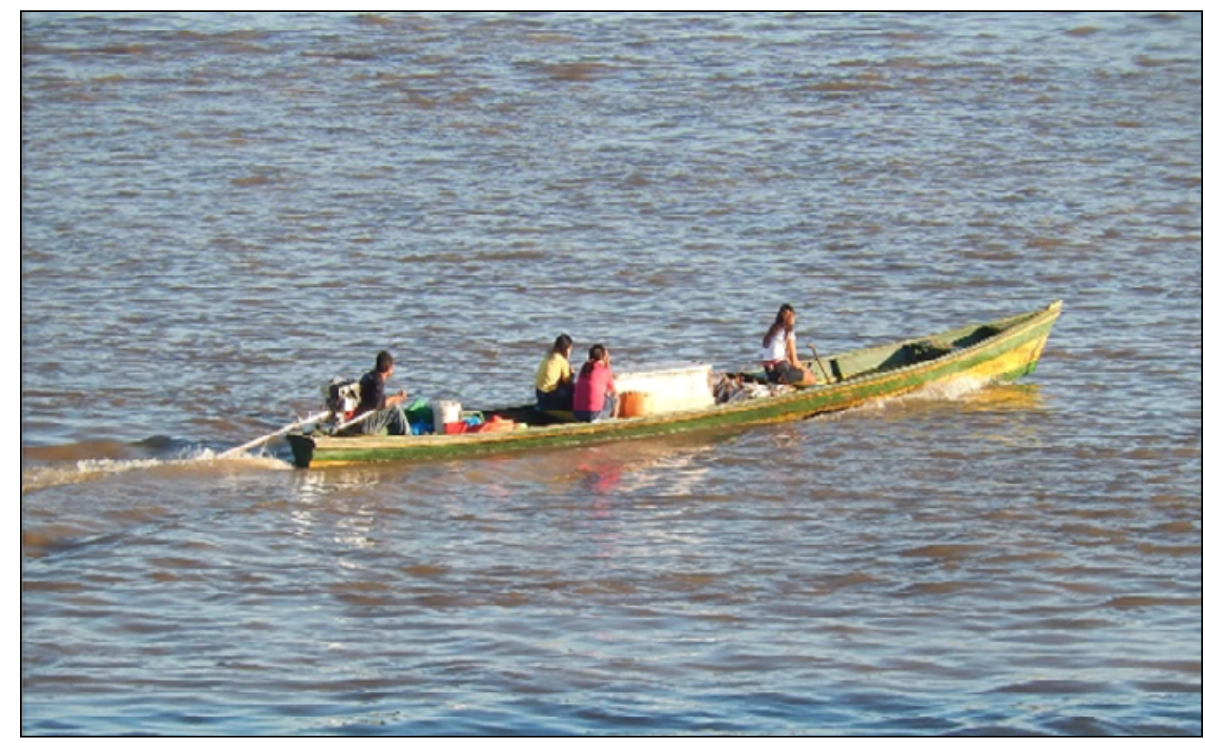

Fonte: Pesquisa de campo, 2019.

Por fim, as dinâmicas sociogeográficas das comunidades ribeirinhas da Amazônia se constituem na relação dos grupos com a natureza, configurando-se em territórios pesqueiros. Esse processo alcança equilíbrio quando a atividade produtiva, geradora de trabalho e renda, não é demasiadamente pressionado por fluxos mercantis externos. Quando as variáveis externas se internalizam nas comunidades, nos territórios pesqueiros, a solidariedade orgânica se fragiliza (Santos, 2000), erodindo a capacidade dos grupos em se verem de modo coletivo para fazer frente ao domínio do capital comercial - atravessadores - que tende a influenciar a vidada coletiva, o vivido territorial, dessas comunidades. No caso analisado, o mercado é o "agente" motivador da exploração mais intensiva dos recursos do território, sendo necessário certa convergência na gestão desses espaços para que as comunidades não sejam fragilizadas em seu cotidiano, que envolve trabalho, renda, comunidade e comunhão. 


\section{Geografia, território e sociedade na Amazônia}

\section{CONSIDERAÇÕES FINAIS}

As lutas firmadas por comunidades ribeirinhas que vivem e utilizam o ecossistema na Amazônia têm como principal objetivo proteger os recursos naturais, sobretudo os pesqueiros, que vem passando por longo processo de exploração desordenada e crescente na pesca comercial. Além disso, o crescimento da produção pesqueira tem gerado conflitos entre as categorias de pescadores, notadamente pelo uso e apropriação do território.

Desse modo, este trabalho buscou problematizar algumas questões sociais e ambientais que vêm ocorrendo na comunidade ribeirinha Terezina III, cujos conflitos pelo acesso, uso e apropriação do território têm importância social para essas comunidades. Contudo, compreendemos que são espaços de difícil ordenamento, pois, além de comportarem grande extensão territorial, apresentam a junção de três países que formam uma tríplice fronteira, que une costumes, crenças, ideologias, culturas e saberes que, consequentemente, nem sempre estarão em sintonia e respeitarão os territórios demarcados.

De modo geral, compreende-se que a ação do estado brasileiro em regiões de fronteira, sobretudo em atendimento às comunidades tradicionais, deve priorizar a atenção social (saúde, educação) e econômica (produção, transportes) para que as atividades produtivas e os territórios tradicionais possam estar cada vez mais adequados às condições de vida e de defesa da natureza. As comunidades ribeirinhas já demostraram capacidade de preservação ambiental, contudo, as escalas econômicas têm potencial elevado para pressionar de modo regressivo a sustentabilidade dos territórios tradicionais. Em muitos casos, esse processo se mostra avassalador na Amazônia.

Para a ciência geográfica, há um universo social, cultural e natural a ser pesquisado, um mundo a ser entendido que se chama Amazônia. Essa região é formada por mosaicos espaciais que elencam desde metrópoles, cidades médias, cidades regionais, pequenas cidades e povoados, ao mundo rural, configurado em espaço agrário, florestal, das águas (rios e lagos) e dos povos amazônicos, no qual vivem milhares de famílias. Esse universo ribeirinho é por demais complexo, exigindo metodologias compatíveis à leitura da complexidade sociogeográfica que modelam a Amazônia mais profunda.

Se pensarmos que nos limites fronteiriços com vários países que margeiam a Amazônia brasileira, pode-se argumentar que se trata de 
uma região muito narrada como periferia do Brasil. Contudo, nesse universo, há relações sociais e políticas econômicas e culturais que dinamizam e tencionam a vida na fronteira, cuja expressão espacial é o universo de rios e florestas dos povos amazônicos, que sentem os desafios e pressões externas que cada vez mais alcançam os territórios tradicionais.

Assim, as contribuições assentadas neste trabalho buscam entender os territórios pesqueiros como expressão das comunidades ribeirinhas na tríplice fronteira no universo amazônico das águas. Como demonstrado, o território pesqueiro pode ser compreendido por meio do estudo das dinâmicas do trabalho nas comunidades ribeirinhas, e pelo uso diário do lago por diversos atores sociais que tecem toda uma vida junto aos encontros e desencontros que a atividade pesqueira presenteia.

\section{Agradecimentos}

A pesquisa contou com apoio das instituições: Conselho Nacional de Desenvolvimento Científico e Tecnológico (CNPq) e Fundação Rondônia de Amparo ao Desenvolvimento das Ações Científicas e Tecnológicas e à Pesquisa (Fapero).

\section{REFERÊNCIAS}

ADAMS, C. (org) et al. Sociedades caboclas amazônicas: modernidade e invisibilidade. São Paulo, Fapesp, 2006.

ALMEIDA, O. T. O manejo de pesca na Amazônia brasileira. São Paulo: Peirópolis, 2006.

BARTHEM, R. B. GOULDING, M. Os bagres balizadores: ecologia, migração e conservação de peixes amazônicos. Tefé: Sociedade Civil Mamirauá; Brasília: CNPq, 1997.

CAVAlCANTE, M. M. A; NUNES, D. D; COSTA SILVA, R. G; LOBATO, L. C. H. Políticas territoriais e mobilidade populacional na Amazônia: estudo sobre as hidrelétricas de Jirau e Santo Antônio no Rio Madeira/ Rondônia/Brasil. In: XVI Encontro Nacional de Estudos Populacionais. Anais... Caxambú: ABEP, 2008. p. 2-18.

COSTA SILVA, R. G. Espaço, sociedade e natureza em Rondônia. Revista Geoamazônia, v. 1, p. 144-165, 2014. Disponível em: www.dx.doi.org/ 10.17551/2358-1778/geoamazonia.n2v1p144-165. 
COSTA SILVA, R. G.; NEVES, J. G. Território, Direitos Humanos e Educação do/no campo na Amazônia. Revista de Educação Pública (UFMT), Cuiabá, v. 27, p. 635-655, 2018. Disponível em: www. periodicoscientificos.ufmt.br/ojs/index.php/educacaopublica/article/ view/6887/4458.

CRUZ, M. J. M. Rios e Lagos: apropriação da pesca pelos camponeses-ribeirinhos na Amazônia. In: BRAGA, Sérgio Ivan Gil (Org.) Cultura popular, patrimônio material e cidades. Manaus: EDUA, 2007.

CUNHA, G. D. O. B.; COSTA SILVA, R. G. Invisibilidades produzidas: o "desaparecimento" das comunidades ribeirinhas nos estudos da hidrelétrica Tabajara (Amazônia brasileira). Revista Interdisciplinar de Direitos Humanos. Bauru, v. 7, p. 95-116, 2019. Disponível em: www3. faac.unesp.br/ridh/index.php/ridh/article/view/713/321.

DIEGUES, A. C. S. O mito moderno da natureza intocada. São Paulo: NUPABUSP, 1994. Disponível em: www.periodicos.ufpa.br/index.php/ ncn/article/view/450. Acesso em: 30 set. 2020.

BARTHEM, R. B.; GOULDING, M. Os bagres balizadores: ecologia, migração e conservação de peixes amazônicos. Tefé: Sociedade Civil Mamirauá; Brasília: CNPq, 1997.

EUZÉBIO, E. F. Fronteira e horizontalidade na Amazônia: as cidades gêmeas de Tabatinga (Brasil) e Letícia (Colômbia). 2011. Universidade de São Paulo. Departamento de Geografia. Dissertação de Mestrado. São Paulo.

FREITAS, C. E. C. RIVAS, A. A. F. A pesca e os recursos pesqueiros na Amazônia ocidental. Ciência \& Cultura [online]. 2006, vol.58, n. 3, p. 20-32.

GOTTMANN, J. The evolution of the concept of territory. Social Science Information, v. 14, n. 3, ago. 1975. p. 29-47.

HAESBAERT, R. Viver no limite: território e multi/transterritorialidade em tempos de insegurança e contenção. Rio de Janeiro: Bertrand Brasil, 2014.

IBGE. Portal Cidades e Estados. Município de Tabatinga - Panorama, 2020. Disponível em: www.cidades.ibge.gov.br/brasil/am/tabatinga/ panorama.

MACHADO, L. O. Mitos e realidades da Amazônia brasileira no contexto geopolítico internacional (1540-1912). Tese de Doutorado. Departamento de Geografia Humana. Universidade de Barcelona. 1989. 
MORAES, A. O; SCHOR, T; ALVES-GOMES, J. A. O Mercado de Bagres e a Configuração da Rede Urbana no Alto e Médio Solimões, Amazonas, Brasil. Caderno Prudentino de Geografia. v. 1, n. 32, p. 93-110. 2010. Disponível em: www.agbpp.dominiotemporario.com/ doc/CPG32A-8.pdf.

MORAES, A. O; SCHOR, T; ALVES-GOMES, J. A. Relações de Trabalho e Transporte na Pesca de Bagres no Rio Solimões (AM). Novos Cadernos NAEA. v. 13, n. 1, p. 155-170. 2010. Disponível em: www. periodicos. ufpa.br/index.php/ncn/article/view/450.

MORAES, A. O. Peixes, redes e cidades: aspectos socioambientais da pesca comercial de bagres no médio e alto Solimões (AM). 2012. 140 f. Dissertação (Mestrado em Ciências do Ambiente e Sustentabilidade na Amazônia) - Universidade Federal do Amazonas, Manaus, 2012. Disponível em: www.tede.ufam.edu.br/handle/tede/2533.

PAIVA, E. J. S. Notas iniciais sobre "rios tradicionalmente ocupados": formas de uso e manutenção dos saberes da pesca na Amazônia. In: COSTA SILVA, R. G; LIMA, L. P; CONCEIÇÃO; F. S. (Org.). Amazônia: dinâmicas agrárias e territoriais contemporâneas. São Carlos: Pedro \& João Editores, 2018, v. 1, p. 287-308.

PAIVA, E. J. S. Territórios pesqueiros: a pesca comercial e o co-manejo pesqueiro em comunidades ribeirinhas da microrregião do alto Solimões/ Amazonas. 2019. 152 folhas. Dissertação, Programa Pós-Graduação Geografia (PPGG) - Universidade Federal de Rondônia - UNIR, Porto Velho, 2019.

PAIVA, M. P. Administração pesqueira no Brasil. Rio de Janeiro: Interciência, 2004.

PETRERE JR, M. A pesca comercial no rio Solimões-Amazonas e seus afluentes: análise dos informes do pescado desembarcado no mercado municipal de Manaus (1976-1978). Manaus: Ciência e cultura, 1985.

PORTO, M. F; PORTO, P. S. S. Conflitos por água no Brasil e a defesa dos comuns: uma leitura a partir da ecologia política e da experiência do mapa de conflitos envolvendo injustiça ambiental e saúde. Disponível em: www.conexaoagua.mpf.mp.br/arquivos/artigos-cientificos/2016/ 14-con flitos-por-agua-no-brasil-e-a-defesa-dos-comuns.pdf. Acesso em: 7 jun. 2020.

PROVARZEA, Projeto Manejo dos Recursos Naturais da Várzea/ Ibama. A pesca na região amazônica: debates para uma possível solução/projeto manejo dos recursos naturais da Várzea/Ibama. - Brasília: Ibama, 2005.

RAFFESTIN, C. Por uma geografia do poder. São Paulo: Ática. 1993. 
RAGGI ABDALLAH, P. Atividade pesqueira no Brasil: política e evolução. Tese (Doutorado em Ciências. Área de concentração: Economia Aplicada) - Escola Superior de Agricultura Luiz de Queiroz/ USP. São Paulo - 1998.

RAMALHO, C. W. N. Pescados, pescarias e pescadores: notas etnográficas sobre processos ecossociais. Boletim do Museu Paraense Emílio Goeldi. Ciências Humanas, v. 11, n. 2, p. 391-414, maio-ago. 2016. Universidade Federal de Pernambuco. Recife, Pernambuco, Brasil.

RAPOZO, P. Territórios sociais da pesca: usos e formas de apropriação comum dos recursos pesqueiros em áreas de livre acesso. Manaus: EDUA, 2015.

REZENDE, Tadeu Valdir Freitas de. A conquista e a ocupação da Amazônia brasileira no período colonial: a definição das fronteiras. Tese de Doutorado. Departamento de História Econômica, FFLCH, USP, 2006.

RUFFINO, M. L. Gestão do uso dos recursos pesqueiros na Amazônia. Manaus: Ibama, 2005.

SANTOS, M. O espaço dividido: os dois circuitos da economia urbana dos países subdesenvolvidos. Rio de Janeiro: Francisco Alves, 1979.

SANTOS, M. Por uma outra globalização: do pensamento único à consciência universal. São Paulo: Record, 2000.

SAQUET, M. A. As diferentes abordagens do território e a apreensão do movimento e da (i)materialidade. Geosul, Florianópolis, v. 22, n. 43, p. 55-76, jan./jun. 2007.

SCHERER, E. Mosaico Terra-Água: a vulnerabilidade social ribeirinha na Amazônia - Brasil. In: VIII Congresso Luso-Brasileiro de Ciências Sociais; Coimbra, Portugal. Universidade de Coimbra, 2004.

SCHWADE, T. M. M. O território agrário ao longo dos rios no Amazonas. Revista Cerrados (Unimontes), v. 17, p. 96-125, 2019. Disponível em: https://doi.org/10.22238/rc24482692201917029612. Acesso em: 28 set. 2020.

SILVA, C. N. Geografia e representação espacial da pesca na Amazônia paraense. Belém: GAPTA/UFPA, 2012. 


\title{
O LUGAR E A VÁRZEA AMAZÔNICA: OS ESPAÇOS COTIDIANOS DO CAMPONÊS AMAZÔNICO ${ }^{1}$
}

\author{
Elisane Pereira da Silva* \\ Ricardo Gilson da Costa Silva"*
}

\section{INTRODUÇÃO}

No lugar, estamos condenados a conhecer o mundo pelo que ele já é, mas, também pelo que ainda não é. O futuro, e não o passado, torna-se nossa âncora (Santos, 2014, p. 163).

$\mathrm{Na}$ sociedade moderna nos depararmos com uma complexidade de eventos que, por ocorrerem em escala global, transcendem as fronteiras do local, porém, têm sua reprodução materializada no lugar. Como nos afirma Santos (2014), o lugar é a oportunidade do evento e, também, depósito final deste. A articulação e a sobreposição do local e do global possibilita que essas escalas se apresentem como uma das especificidades do corrente período técnico-científico-informacional, devido a rapidez da informação e da fluidez da comunicação.

A globalização da economia não proporcionou a homogeneização dos lugares, pelo contrário, permitiu reforçar a diferenciação e as especificidades locais, sem desassociar-se da ordem global. $\mathrm{O}$ artigo tem como objetivo compreender a várzea amazônica a partir de sua organização socioeconômica e transformações resultantes da relação entre variáveis endógenas e exógenas.

\footnotetext{
${ }^{1}$ Artigo publicado em: SILVA, Elisane Pereira da; COSTA SILVA, Ricardo Gilson. O lugar e a várzea amazônica: os espaços cotidianos do camponês amazônico. Ciência Geográfica, Bauru - Vol. XXV, n., p. 682-694, Jan./Dez., 2021.

" https://orcid.org/0000-0002-9833-4927

" https://orcid.org/0000-0002-3348-9629
} 


\section{Geografia, território e sociedade na Amazônia}

A pesquisa utilizou uma das categorias-chave da geografia, o lugar. Assim, a escolha desta categoria geográfica parte do entendimento que essa fração do espaço dinâmico do cotidiano do camponês amazônico pode vir a contribuir de forma significativa para a compreensão do espaço geográfico como um todo. Deste modo, discute-se a categoria "lugar" enquanto espaço vivido e construção socioespacial, de modo a contribuir para o entendimento da várzea amazônica e das mudanças sociais que ocorrerem em seu interior, principalmente em função das experiências produtivas desenvolvidas pelos camponeses amazônicos.

Dessa maneira, entendemos o lugar como a soma de objetos materializados e sistema de relações contrastantes (subjetivo-objetivo, aparência-essência, mediato-imediato, real e simbólico). Assim, nas comunidades do Furo Cachoeiry, localizadas no município de Oriximiná, oeste do Pará, é comum observarmos os seguintes pares dialéticos: o novo e o velho, o tradicional e o moderno, o exógeno e o endógeno, enfim, as mudanças e permanências materializadas no espaço geográfico da várzea amazônica (Costa Silva; Conceição, 2017).

O lugar, segundo Souza (2013), é o espaço percebido e vivido que se configura num conjunto de significados, dos quais se desenvolvem e se extraem os "sentidos de lugares" e as "imagens de lugares". Para o autor, a dimensão cultural-simbólica é fundamental para o entendimento das identidades, das intersubjetividades e das trocas simbólicas que antecedem a construção de imagens e sentidos dos lugares como espacialidade vivida e percebida. E acrescenta: "o lugar está para a dimensão cultural-simbólica assim como o território está para a dimensão política” (Souza, 2013, p. 115), elucidando a relevância da dimensão cultural-simbólica para a concepção de lugar.

Partindo do entendimento de ser um espaço dotado de significado, um espaço vivido, o lugar assume o status de espaço social. Assim, o lugar, por ser um espaço produzido socialmente, fruto da transformação e apropriação da natureza; contudo, desconectado de significado e vivência, leva ao entendimento que todos os espaços sociais podem ser um "lugar" (Souza, 2013). Da mesma maneira, por ser constituído nos espaços do cotidiano, o lugar "é a porção do espaço apropriado para a vida, apropriação através do corpo, dos sentidos, dos passos de seus moradores, é o bairro, é a praça, é a rua” (Carlos, 2007, p. 20).

A estrutura deste artigo parte dos dois pontos que nortearam a pesquisa: o lugar e a várzea amazônica. Na primeira parte, abordaremos a categoria geográfica lugar na perspectiva de Carlos (2007) e Santos 
(2014). Na segunda parte, destacamos a várzea amazônica como o lugar do camponês amazônico.

\section{O LUGAR COMO CATEGORIA GEOGRÁFICA: UM ESPAÇO VIVIDO, PERCEBIDO E SOCIALMENTE CONSTRUÍDO}

Algumas das categorias chaves da geografia se destacam quanto a sua relevância para o entendimento geográfico crítico, como é o caso da categoria de paisagem, território, lugar, região e espaço geográfico. De modo geral, a paisagem ocupa-se da fração do espaço que é visível e perceptível por meio dos sentidos: “Tudo o que nós vemos, o que nossa visão alcança, é a paisagem. Esta pode ser definida como o domínio do visível, aquilo que a vista abarca. É formada não apenas de volumes, mas também de cores, movimentos, odores, sons, etc." (Santos, 2014, p. 67-68).

Com relação ao território, este se refere a um espaço delimitado, onde suas fronteiras são determinadas social e politicamente: "é fundamentalmente um espaço definido e delimitado por e a partir de relações de poder" (Souza, 2013). O espaço geográfico é a categoria principal da geografia, ou melhor, é o objeto de estudo desta ciência e, segundo Corrêa (2003), definir esse espaço é uma tarefa complexa, pois essa categoria tem variação de escala, desde a Geografia Tradicional até as ideias mais recentes da Geografia Cultural. Mesmo o espaço geográfico sendo discutido em diferentes perspectivas, vale ressaltar que essa categoria geográfica se refere à fração do espaço habitado e transformado pelo homem, sendo o resultado de conflitos e lutas da sociedade.

Quanto à região, essa categoria ocupa-se da continuidade do espaço dotado de características semelhantes e particulares, sejam essas econômicas, naturais, sociais ou culturais. No entanto, essa categoria, enquanto conceito geográfico, tem em seu debate epistemológico a relação contínua entre a política e o território, entre limites territoriais de soberania ou autonomia (Gomes, 2003). Quanto à categoria lugar, essa constitui uma parcela do espaço cotidianamente experimentado pelo sujeito, ou seja, o lugar se destaca quanto a sua relevância para o sujeito, pois é nessa fração do espaço que se constrói a identidade pessoal e ocorrem as relações afetivas e sociais: "um espaço percebido e vivido, dotado de significado, e com base no qual desenvolvem-se e extraem-se os 'sentidos de lugar' e as 'imagens de lugar'” (Souza, 2013, p. 114). São os arranjos dos "sentidos de lugar" e das "imagens do lugar" no 


\section{Geografia, território e sociedade na Amazônia}

cotidiano do sujeito que vai configurando o espaço geográfico, como aponta Moreira:

Todos moramos em lugares e temos familiares e amigos que moram em outros lugares. Estes diferentes lugares são ligados por ruas, avenidas e estradas. Pessoas, objetos e ideias fluem entre esses diferentes, entrecruzam-se através das artérias que põem em comunicação. Ajudam-se ou ignoram-se. De diferentes lugares são extraídos recursos que em diferentes lugares são transformados em objetos uteis e que são intercambiados entre diferentes homens. Uma combinação de lugares e de relações entre lugares tece uma unidade de espaço, o espaço geográfico, constituindo o espaço da existência dos homens (Moreira, 2005, p. 56-57).

O lugar, por se referir ao "nosso próximo", é o espaço que experimentamos as relações de vizinhança e/ou proximidade, em que prevalece as subjetividades e as relações de afetividade. Isso posto, para entender as transformações ocorridas nesse espaço precisamos transpor as análises da racionalidade, pois, a subjetividade também incorpora as ações humanas, motivando suas atividades, tendo em vista que "uma dada situação não pode ser plenamente apreendida se, a pretexto de contemplarmos sua objetividade, deixamos de considerar as relações intersubjetivas que a caracterizam" (Santos, 2014, p. 215).

Assim, a proximidade da categoria "lugar" com o sujeito não a torna um conceito de análise simples, pois, possibilita revelar informações relevantes a respeito da sociedade que o constitui em complexidade. A natureza do lugar lhe garante destaque na atualidade, deixando de ser simples instrumento de localização ou base física, ganhando expressão de uma construção socioespacial produzida a partir das relações entre os atores sociais e a base territorial utilizada como arena tanto para viver como para sobreviver:

Um lugar não é apenas um quadro de vida, mas um espaço vivido, isto é, de experiências renovadas, o que permite, ao mesmo tempo, a reavaliação das heranças e a indagação sobre o presente e o futuro. A existência naquele espaço exerce um papel revelador sobre o mundo (Santos, 2000, p. 114).

Assim, o lugar passa a se constituir em espaço cotidiano de cada ator social que dele vive, percebe e o constrói socialmente, como expõe Carlos: 


\section{lugar e a várzea amazônica: os espaços cotidianos do camponês amazônico}

São os lugares que o homem habita dentro da cidade que diz respeito a seu cotidiano e a seu modo de vida onde se locomove, trabalha, passeia, flana, isto é, pelas formas através das quais o homem se apropria e que vão ganhando significado dado pelo seu uso (Carlos, 2007, p. 18).

No momento atual, o processo de globalização e a internacionalização da produção e consumo são um dos principais eventos a ocasionar que os lugares se tornem cada vez mais especializados, sem que, mesmo envoltos nesses dois processos totalizantes, o lugar não elimine todos os aspectos particulares de sua identidade: "Cada lugar é, ao mesmo tempo, objeto de uma razão global e de uma razão local, convivendo dialeticamente" (Santos, 2014, p. 239). As particularidades dos lugares que os individualizam podem ser observadas nas relações sociais, nas atividades econômicas e culturais e, por meio dessas manifestações verificadas no lugar, podemos entender muito sobre o mundo.

Dessa forma, a interligação entre o local e o global é consequência do avanço das redes ocasionado pelo aumento do fluxo de informações, bens e serviços. Essa interligação influencia - direta e indiretamente - a transformação do lugar em decorrência das inúmeras ações externas que o alcança, através dos meios de comunicações e/ou transportes. Assim, o lugar passa a integrar um circuito, com sua função estrutural definida pelo processo de produção capitalista, desempenhando suas atribuições dentro da cadeia produtiva a qual faz parte.

Por outro lado, além de promover a interligação, as redes também propiciam a comunicação entre o local e o global. Para Santos (2014), as redes possibilitam o reconhecimento de três níveis de solidariedade: na escala mundial, na escala dos territórios dos Estados e na escala local. As redes, ao mesmo tempo em que conectam essas totalidades, elas também evidenciam as particularidades das mesmas: “As redes são um vínculo de um movimento dialético que, de uma parte, ao Mundo opõe o território e o lugar; e, de outra parte, confronta o lugar ao território tomado como um todo" (Santos, 2014, p. 270).

$\mathrm{Na}$ geografia, a categoria "lugar" ganha destaque no debate dentro da Geografia Crítica e da Geografia Humanística, e essas duas correntes passaram a intensificar a relação entre o homem e o meio no debate conceitual. Na Geografia Humanística, de modo geral, as relações subjetivas estabelecidas entre o ser humano e o meio norteavam os debates fundamentados metodologicamente na associação da fenomenologia e existencialismo. Assim, essa corrente geográfica utilizava o 


\section{Geografia, território e sociedade na Amazônia}

Lugar como principal conceito em suas abordagens, estabelecendo um diálogo entre o homem, meio, natureza e vida social a partir da percepção, pensamentos, símbolos e ação (Buttimer, 1982).

O lugar na Geografia Humanística adquire significado de "espaço vivido" (Corrêa, 1995), evidenciando as relações e experiências do indivíduo/ser humano com o espaço cotidiano. Daí a relevância da subjetividade nessas análises, ao mesmo tempo em que um espaço é significativo para um indivíduo, dotado de lembranças e sensações de pertencimento, esse mesmo espaço, para outro indivíduo, pode expressar outros significados. O lugar é um espaço de referência, de identidade, de emoções compartilhadas.

Em Geografia Crítica, o lugar assume a condição de singularidade, como uma fração do espaço com formação histórica, política, social, econômica e cultural, e por mais que essa formação esteja inserida nos fluxos da globalização, apresenta características particulares que o diferencia do resto do mundo. Essa análise tem como base o processo de globalização e a internacionalização da economia por meio da modernização das redes, que possibilita cada vez mais a interligação dos mais variados pontos do planeta. Nessa perspectiva, se por um lado o mundo tende a uma aproximação homogeneizadora, por outro lado, as singularidades do lugar se destacam, uma vez que a globalização não atinge o objetivo de formar igual todos os lugares.

É dentro deste contexto que o lugar surge tanto como uma expressão do processo de homogeneidade do espaço imposta pela dinâmica econômica global, quanto uma expressão da singularidade, na medida em que cada lugar exerce uma função imposta pela divisão internacional do trabalho (Leite, 1998, p. 17).

Nessa perspectiva, o lugar é compreendido como produto das relações capitalistas, resguardando suas singularidades; desse modo, "cada lugar é extremamente distinto do outro, mas também claramente ligado a todos os demais, por um nexo único, dado pelas forças motrizes do modo de acumulação hegemonicamente universal (o capitalismo)" (Santos, 2014, p. 28). No entanto, a Geografia Crítica não utiliza apenas o aspecto econômico nas análises do lugar, mas adiciona a formação histórica e as relações estabelecidas cotidianamente entre os atores sociais. Assim, o lugar é compreendido como o espaço diariamente vivido pelo homem: 
Significa pensar a história particular (de cada lugar), se desenrolando, ou melhor, se realizando em função de uma cultura/ tradição/língua/hábitos que lhes são próprios, construídos ao longo da história e o que vem de fora, isto é, que se vai construído e se impondo como consequência do processo de constituição mundial (Carlos, 2007, p. 20).

A relevância do lugar para uma análise crítica do espaço decorre deste ser "nosso próximo", onde se manifesta a cooperação e o conflito, a permanência e a mudança, a criação e a recriação das dinâmicas determinadas pelas ordens internas e externas. O cotidiano possibilita identificar e analisar as relações de vizinhança, assim como os conflitos e as diferenças manifestadas no lugar (Santos, 2014).

$\mathrm{Na}$ várzea amazônica é visível essa noção de mudança e a lembrança em relação ao tempo do cultivo de lavouras, das grandes festas religiosas, do vai e vem das embarcações e do convívio familiar. Na perspectiva crítica, o lugar é compreendido como uma construção solidária entre o mundo, onde essa solidariedade se manifesta por três tipos distintos: o tipo de vida espontânea que "exprime a ordem local, fundada numa organização solidária que emerge do trabalho compartido da vizinhança, da emoção"; o tipo organizacional, "criada pela razão técnica, os cálculos e produtividade" e o tipo mercantil, estabelecido por diferentes normas “a um espírito de cálculo e previsão" (Silveira, 1996, p. 67).

Desse modo, o lugar é pensado como produto das relações humanas, homem e natureza, conjunto das relações sociais estabelecidas cotidianamente, espaço "nosso próximo" que garante a estruturação de uma rede de significados e sentidos procedentes do processo histórico e cultural de nossa sociedade, por consequência, cria uma identidade local (Carlos, 2007).

$\mathrm{Na}$ atualidade, a globalização da economia e a inovação nos meios de comunicação e transporte possibilitam uma interconexão entre inúmeros pontos do mundo simultaneamente, todavia, as inovações não são acessíveis a todos, em razão de seus valores econômicos e/ou étnico-culturais. O processo de globalização e a internacionalização da produção e do consumo possibilitaram que os lugares se tornassem cada vez mais especializados. Apesar do lugar estar circundado desses processos totalizantes, ele não apresenta prejuízo a sua identidade, dado que “[...] cada lugar, irrecusavelmente imenso numa comunhão com o mundo, torna-se exponencialmente diferente dos demais. A uma maior globalidade corresponde uma maior individualidade” (Santos, 2014, p. 214). 
A várzea compreende a área das grandes faixas marginais dos leitos dos rios, que oscilam entre uma fase terrestre e outra aquática. Em consequência dessa oscilação, o ecossistema de várzea comporta organismos terrestre e aquáticos que se adaptaram às sazonalidades dos rios (Sioli, 1985; Lima; Tourinho, 1994). Para Junk (1997), essa heterogeneidade espaço-temporal inclui as duas fases fluviais (cheia e seca), sendo fundamentais para o sistema de várzea, de forma interligada e não dissociada.

Isto posto, há que se estabelecer uma conexão entre o lugar e a várzea amazônica. Esse exercício se faz necessário pelo fato de a várzea apresentar, em sua maioria, unidade produtiva e unidade familiar indissociáveis das milhares de famílias que vivem neste ambiente (Monteiro, 1981; McGrath, 1991;). A indissociabilidade ocorre pelo fato de a várzea assegurar tanto a moradia - lugar de sociabilidade da família, como o espaço de produção - e local das estratégias de reprodução social e econômica, uma vez que as atividades produtivas desenvolvidas se fundamentam na agricultura familiar e no extrativismo comunitário (Figura 1). Embora se tenha observado, há pouco tempo, que o desenvolvimento de atividades não agrícolas em algumas das comunidades do Furo Cachoeiry, onde tais atividades possibilitam o afastamento do lugar, moradia do lugar e produção, não há perda da identidade do indivíduo com o local em que ele reside. 
Figura 1 - Imagem da Casa e da horta de duas famílias camponesas da comunidade Santo Antônio - Furo Cachoeiry.

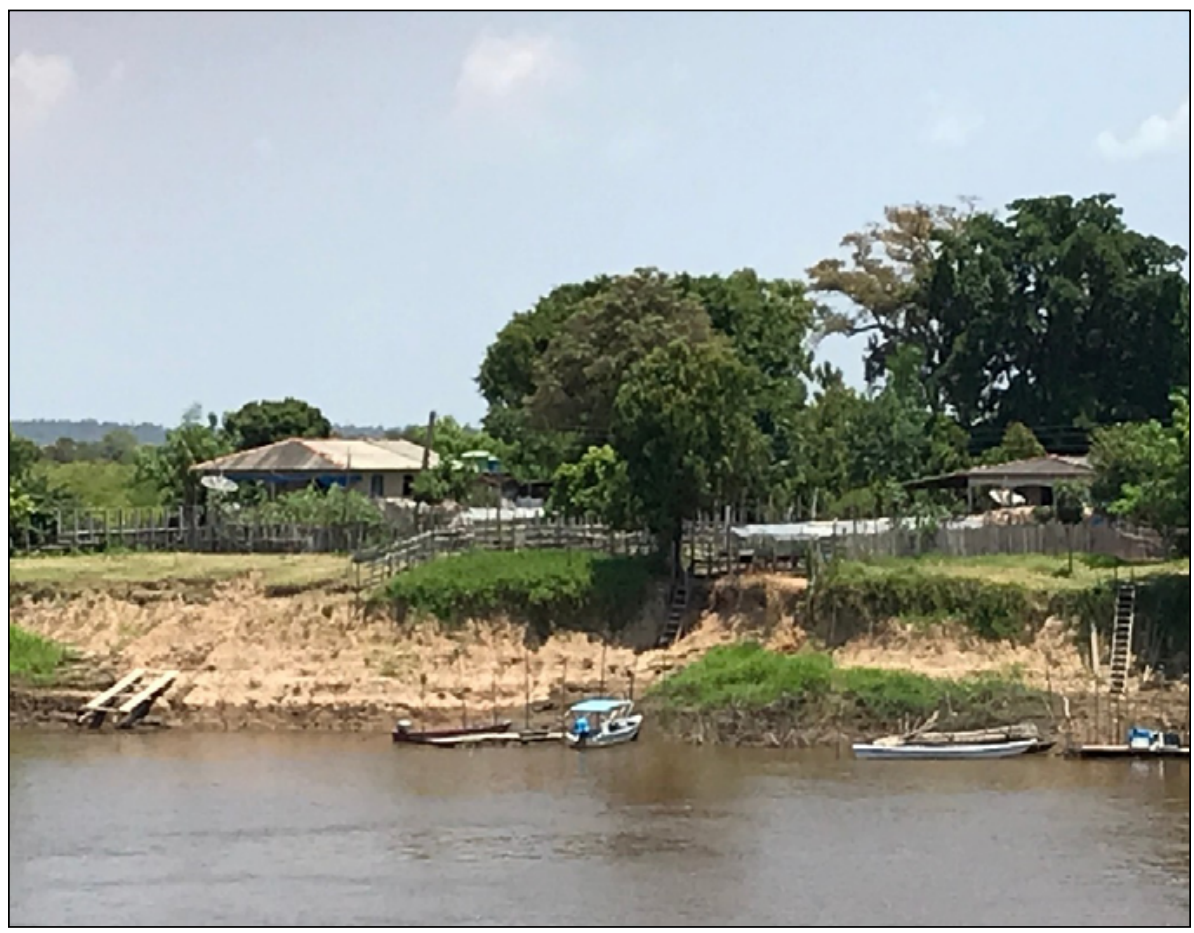

Fonte: Arquivo pessoal, 2018.

A respeito da relação entre a produção rural e a atividade econômica do camponês amazônico, e o lugar em que vive, Alves (2004) relata que o entendimento dos elos de socialização entre os moradores se processa na escala da comunidade: "o lugar é tido como a base da vida cotidiana e da sociabilidade entre as pessoas" (Alves, 2004, p. 204). Desse modo, o sentimento de lugar está diretamente conexo às formas de solidariedade, às atividades lúdicas e as de cunho religioso, às relações de parentesco e vizinhança e da possibilidade de os filhos permanecerem tanto na propriedade e/ou comunidade como na atividade agrícola.

Constituída pela complexa inter-relação entre terra, floresta e água, a várzea se manifesta como paisagem humanizada, sobretudo quando ocupada por povos originários muito antes do contato com a colonização portuguesa, e posteriormente, com a ocupação dos ribeirinhos e 


\section{Geografia, território e sociedade na Amazônia}

comunidades quilombolas, de modo a configurar a várzea em múltiplos territórios (Witkoski, 2007). Enquanto lugar cotidiano do camponês amazônico reunido em comunidades ribeirinhas, de suas relações sociais com vizinhos e parentes, do "identitário ribeirinho" e das mais diversas formas de solidariedade religiosa, a várzea possibilita o entendimento da relação dialética entre o tradicional e o moderno de seu processo histórico de produção do espaço. A inserção de novos dispositivos nas comunidades de várzea reorganizou a dinâmica social, atividades recreativas e de produção, tais como: telefonia celular, acesso à internet, consumo de eletroeletrônico e transporte fluvial a motor que, de modo geral, provocou transformações sociais no mundo da várzea.

Uma das particularidades da várzea amazônica é o calendário climático que norteia a dinâmica da produção varzeira, pois, o regime fluvial apresenta quatro períodos distintos: enchente, cheia, vazante e seca. Esses períodos distintos sentidos na várzea estão divididos por mês, da seguinte forma: fevereiro, março e abril são marcados pela enchente; maio, junho e julho caracterizam-se pela cheia do rio, nesse período o rio se encontra em seu nível mais alto; em agosto e setembro inicia a vazante, onde o nível do rio começa a descer; os meses de novembro a janeiro é o período de seca (Pereira, 2007).

A sazonalidade das águas do rio Amazonas (enchente-cheia, vazante, seca) fez com que os camponeses desenvolvessem estratégias para a prática da agricultura, tanto no período de seca, quanto no período de cheia. Uma dessas estratégias foi a técnica de canteiro suspenso e jiraus, construídos na forma de palafitas, que possibilita a produção, durante o ano todo, principalmente de espécies de hortifrúti (Figura 2). 
Figura 2 - Imagem do Canteiro de horta suspensa no período de enchente-cheia, na Comunidade São Luiz - Furo Cachoeiry (Oriximiná/PA).

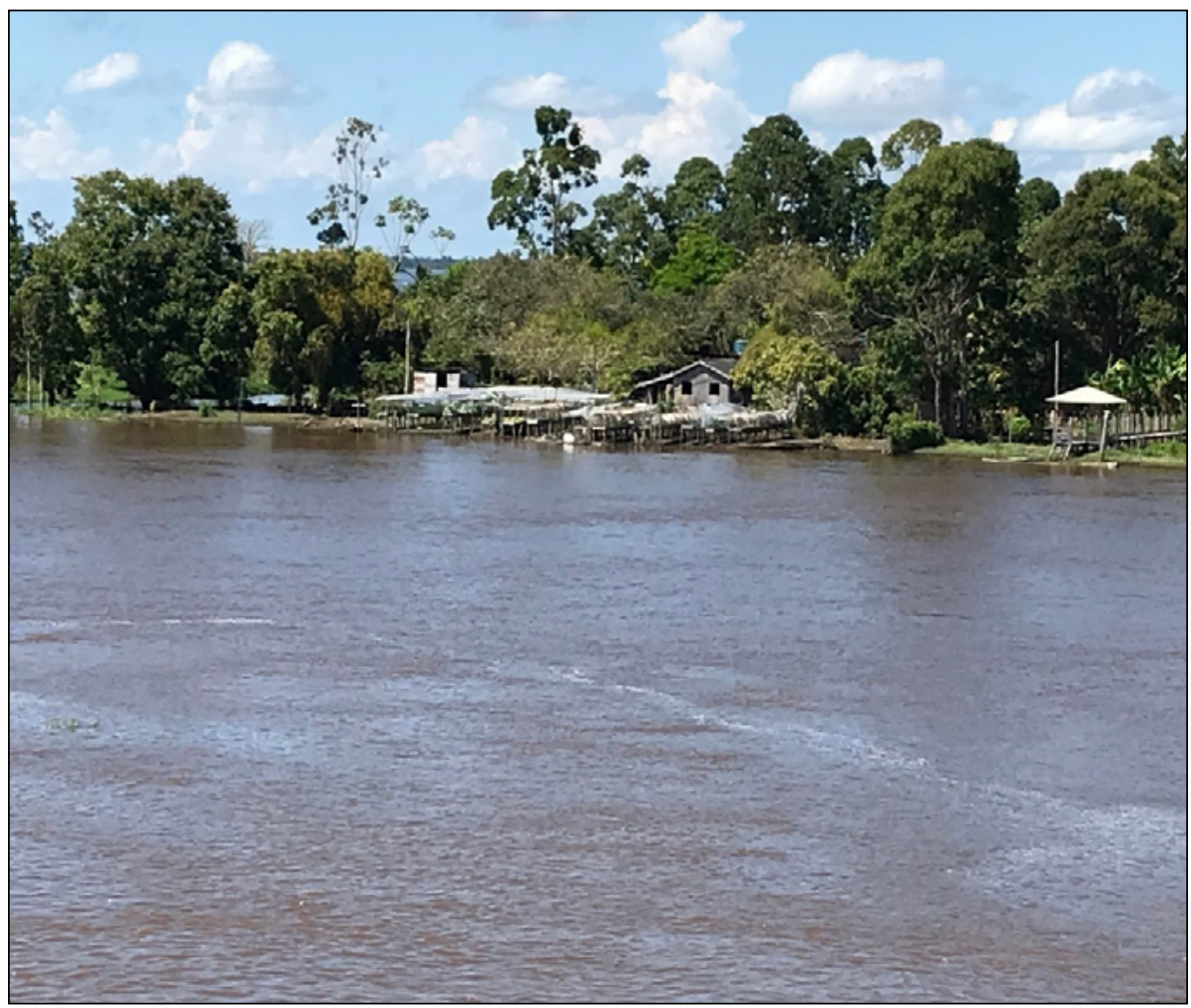

Fonte: arquivo pessoal, 2018.

O ribeirinho amazônico, além do calendário de plantio específico, que atende o regime da sazonalidade das águas do Amazonas, ainda convive com processos de erosão de terra, fenômeno natural que ocorre na várzea amazônica, que consiste na "quebra dos barrancos" e, consequentemente, com risco à propriedade familiar. Esse fenômeno faz parte do cotidiano e da cultura da população da várzea que, mesmo com o risco (perda material e humana) o encaram com "certa" naturalidade (Matos; Cursino, 2012).

As relações de vizinhança, de parentesco e o sentimento de pertencimento ao lugar são particularidades que evidenciam o sentimento 


\section{Geografia, território e sociedade na Amazônia}

e a identidade de "ribeirinho" ao lugar ${ }^{2}$. Outro aspecto relevante, que também manifesta essa identidade, são as atividades desenvolvidas nos três ambientes de várzea: a terra, a água e a floresta:

[...] os meios de produção fundamentais são a terra, a floresta e a água; a mão-de-obra utilizada nas diversas atividades do mundo econômico é, praticamente, familiar, há uma divisão sexual de trabalho na família - seja ela extensa e/ou nuclear; a tecnologia usada é simples, de limitado impacto sobre o meio ambiente; há uma relação simbólica com a natureza, através dos ciclos naturais, o que reflete na elaboração de estratégias de uso e manejo dos recursos naturais, que passam de geração a geração por via oral; importância das atividades de subsistência, ou seja, produção de valores de uso para si e para outros homens - mercadorias; os camponeses amazônicos participam de um mercado em rede; possuem clara noção de território, onde o grupo produz e reproduz econômica, social e politicamente; por fim, poder interno organizado de modo precário em geral, o poder reside nas mãos de agente da comercialização (Witkoski, 2007, p. 163).

Assim, para Witkoski (2007), a identidade de caboclo e do ribeirinho, ou melhor, do camponês amazônico é uma das mais relevantes características da várzea, sendo necessário apontar as comunidades das áreas de várzea como coletividade de parentes e/ou de vizinhos. As comunidades de várzea, enquanto agrupamento agrário, são lugares onde se estabelecem relações de vizinhanças e parentescos, fundamentados na reciprocidade da cooperação e da solidariedade, uma vez que a sobrevivência de uma unidade familiar está associada à unidade familiar do próximo (Canto, 2007; Cruz, 2007).

Ainda, segundo Witkoski (2007), a terra como substrato da floresta e da água nunca, ou quase nunca assume valor de mercadoria, ou seja, valor de troca, pois, para o camponês amazônico, a terra sempre terá sentido de terra, destinada a ser trabalhada. O autor relata:

\footnotetext{
${ }^{2}$ Para Neves (2009), a categoria de ribeirinho é bem aceita pelo produtor varzeiro quando este se encontra no âmbito político, devido assim ser reconhecido e designado neste campo: refere-se ao agente político. Deste modo, essa categoria assume dignificado diferente do que se estruturado no modo de autoidentificação, fundamentado no morador de uma comunidade.
} 


\section{lugar e a várzea amazônica: os espaços cotidianos do camponês amazônico}

A terra e as riquezas que ela guarda são valorizadas como um patrimônio que cria as condições para que o camponês e sua família apareçam como trabalhadores de sua unidade de produção. A terra do camponês amazônico é a terra de várzea e, como tal, possui todas as características similares. Sem a enchente e a cheia, que fertilizam e sem a vazante e a seca, que propiciam as condições para que a terra seja fecundada, as várzeas como terras de trabalho não seriam possíveis (Witkoski, 2007, p. 191).

Entre as inúmeras formas de materialidade da reciprocidade de cooperação e solidariedade existentes nas comunidades varzeiras, as que ocorrem entre familiares (vizinhos ou não), no ambiente escolar e nas práticas religiosas são as mais significativas. $\mathrm{O}_{\text {puxirum }}^{3}$ é uma das materialidades desta ação, pois consiste em uma atividade coletiva - convocada ou não, entre os vizinhos e/ou parentes para ajudar a desenvolver um trabalho que beneficiará uma família e/ou a comunidade como um todo (Conceição; Costa Silva, 2021). O desenvolvimento desta prática ocorre em atividades coletivas como: limpeza de uma área para o plantio de roça, colheita de determinado produto agrícola, ajuda mútua para enfrentar enchentes, dentre outras. Outra forma de reciprocidade de cooperação e de solidariedade praticada entre as famílias é o compartilhamento de produtos de atividade extrativa animal: o peixe e carne de caça:

[...] Se por acaso o vizinho, por alguma razão, não tiver peixe, ele quase sempre é lembrado pelo outro. A solidariedade é uma espécie de amálgama que garante a vida em comunidade, sem ela dificilmente eles conseguiriam se manter, enquanto uma unidade espacial (Canto, 2007, p. 141).

Nesta perspectiva, optou-se pela abordagem do lugar para analisar a várzea por esta categoria geográfica que abrange a relação identidade-sociabilidade-grupo. A várzea amazônica, como lugar, não se difere muito de outros espaços e está submetida diretamente e indiretamente a constantes transformações socioeconômicas, culturais e espaciais ocasionadas, tanto por atores internos, como externos, como, por exemplo:

\footnotetext{
${ }^{3}$ Segundo Canto (2007), essa modalidade de trabalho consiste, principalmente, na convocação ou espontaneidade de parentes e vizinhos que objetiva a ajudar a efetuar determinada atividade que beneficia diretamente uma família ou a comunidade como um todo, sem que haja remuneração direta de espécie, apenas a obrigação moral de ajudar o próximo quando for solicitado.
} 


\section{Geografia, território e sociedade na Amazônia}

introdução de novas funções (preservação ambiental, lazer, uso e aptidão de solo, moradia, etc.), novas formas de ocupação (pluriatividade e as atividades não agrícolas) e, também, modificações nas relações de gênero e no cotidiano da população varzeira.

\section{CONSIDERAÇÕES FINAIS}

No presente trabalho desenvolveu-se uma reflexão referente à categoria geográfica "lugar", no sentido de demonstrar sua importância para a compreensão e explicação dos processos sociais que configuram formas de existir do ser humano e seu meio. O esforço foi demonstrar que nos lugares, o lugar requer, na contemporaneidade, entendimentos de uma construção socioespacial, materializada na relação de cooperação e conflito entre os atores sociais.

Dessa forma, a simples associação do lugar a "uma necessidade antropológica" não consegue mais responder a constituição dessa categoria geográfica, assim como sua significação a um local cognitivo. Para o entendimento do lugar faz-se necessário a integração das ações e dos atores sociais, dos grupos e das trocas tanto materiais com imateriais no espaço.

O pensamento crítico em geografia busca fundamentar seus estudos numa perspectiva analítica mais ampla, que engloba a ação dos fenômenos externos para esse entendimento. Deste modo, o lugar está cada vez mais deixando a posição de espaço vivido em si para uma construção socioespacial que abrange múltiplas escalas dos processos sociais. Neste contexto, a várzea amazônica reúne o tradicional e o moderno, escalas do acontecer solidário que cada vez mais se aproxima e particulariza a vida social.

\section{REFERÊNCIAS}

ALVES, J. A dinâmica agrária do município de Ortigueira (PR) e a reprodução social dos produtores familiares: uma análise das comunidades rurais de Pinhalzinho e Vila Rica, 2004. Dissertação (Mestrado em Geografia). Faculdade de Ciências e Tecnologia, Universidade Estadual Paulista, Presidente Prudente.

CANTO, O. Várzea e varzeiros da Amazônia. Belém: MPEG, 2007.

CARLOS, A. F. A. O lugar no/do mundo. São Paulo: Labur, 2007. 
CONCEIÇÃO, F. S; COSTA SILVA, R. G. Puxirum no Tapajós: lutas sociais e (re)existências camponesas na Amazônia. In: PORTO JÚNIOR, F. G. R. et al (Orgs.). Povos originários e comunidades tradicionais. v. 5: trabalhos de pesquisa e de extensão universitária. Porto Alegre: Editora Fi, 2021. p. 144-167.

COSTA SILVA, R. G. Das margens do Madeira ao interior da floresta: percursos da formação socioespacial de Rondônia (1970-1995). In: ALMEIDA SILVA, A; NASCIMENTO SILVA, M. G. S; SILVA, R. G. C. (Orgs.) Colonização, território e meio ambiente em Rondônia: reflexões geográficas. Curitiba: Editora SK, 2012, v. 1, p. 58-82.

COSTA SILVA, R. G; CONCEIÇÃO, F. S. Agronegócio e campesinato na Amazônia brasileira: transformações geográficas em duas regiões nos estados de Rondônia e Pará. Geographia (UFF), [s.l.], v. 19, p. 54-72, 2017.

CRUZ, M.J.M. Territorialização camponesa na várzea da Amazônia. Tese (Doutorado em Geografia Humana). São Paulo: PPGEO/FFCHL/ USP, 2007. p. 274.

JUNK, W.J. General aspects of floodplain ecology with special reference to Amazonian floodplains. In: Ecological studies. The Central Amazon floodplain. Ed. Springer. v. 126, 1997.

LEITE, A. F. O lugar: duas acepções geográficas. Anuário do Instituto de Geociências, UFRJ, 1998 v. 21.

LIMA, R. R.; TOURINHO, M. M. Várzeas da Amazônia brasileira: principais características e possibilidades agropecuárias. Belém: FCAP. Serviço de Documentação e Informação, 1994.

MATOS, J. de A.; CURSINO, A. M. da S. Caracterização geomorfológica das "terras-caídas" em área de várzea na comunidade Miracauera, Careiro da Várzea-AM. Revista Geonorte, v. 1, n. 4, ed. especial, p. 515-525, 2012.

MCGRATH, D.G., et al. Varzeiros, geleiros e o manejo dos recursos naturais da várzea do Baixo Amazonas. In: Seminário do Núcleos de Altos Estudos Amazônicos: papers do NAEA n. 4. Belém: UFPA, 1991. p. 56. Não publicado.

MONTEIRO, S. T. Anotações por uma história rural do médio Amazonas. Manaus: Emater-AM, 1981. p. 96.

MOREIRA, Ruy. O que é geografia. São Paulo: Brasiliense, 2005. 
NEVES, D. P. Os ribeirinhos-agricultores da várzea: forma de enquadramento institucional. Novos Cadernos NAEA, v. 12, n. 1, p. 67-92, jun. 2009.

PEREIRA, H. S. A dinâmica da paisagem socioambiental das várzeas do Rio Solimões-Amazonas. In: FRAXE, T. J. P; PEREIRA, H. S.; WITKOSKI, A. C. (orgs.). Comunidades ribeirinhas amazônicas: modos de vida e uso dos recursos naturais. Manaus: EDUA, 2007, p. 7-52

SANTOS, M. Por uma outra globalização: do pensamento único à consciência universal. Rio de Janeiro; São Paulo: Record, 2000.

SANTOS, M. Metamorfoses do espaço habitado: fundamentos teóricos e metodológicos da geografia. Em colaboração com Denise Elias. 6. ed. 2. reimp. São Paulo: EdUSP, 2014.

SANTOS, M. Da totalidade ao lugar. 3. reimp. São Paulo: EdUSP, 2014. SILVEIRA, M. L. Uma teoria geográfica da sociedade: razão global e razão local. In: CARLOS, A. F. A. (org). Ensaios de geografia contemporânea: Milton Santos obra revisitada. São Paulo: Hucitec, 1996, p. 63-72. SIOLI, H. Amazônia: fundamentos da ecologia da maior região de floresta tropical. Petrópolis: Vozes, 1985.

SOUZA, M. L. de. Lugar e (re[s])significação espacial. In: Os conceitos fundamentais da pesquisa sócio-espacial. Rio de Janeiro: Bertrand Brasil, 2013. p. 111-134.

WITKOSKI, A.C. Terras, florestas e águas de trabalho: os camponeses amazônicos e as formas de uso de sus recursos naturais. Manaus: EdUFAM, 2007. (Série: Amazônia: a terra e o homem) 


\title{
A SUbJUGAÇão DA FORÇA DE TRABALHO QUILOMBOLA AO CAPITAL Na AMAZÔNIA: ANÁlise SOBRE O QUILOMbo BoA Vista no município de Oriximiná (Pará) ${ }^{1}$
}

\author{
Silvia da Silva Correa" \\ Alyson Fernando Alves Ribeiro** \\ Ricardo Gilson da Costa Silva***
}

\section{INTRODUÇÃO}

A incorporação da Amazônia brasileira aos mecanismos de reprodução ampliada do capital atinge todas as áreas geográficas da região, alterando seus liames internos e as formas sociais secularmente presentes. No espaço rural, esse processo geográfico configura as novas escalas da relação social, ampliando as relações externas das populações e das comunidades amazônicas que viviam eminentemente dos recursos do território, sem impor alterações significativas em seu meio geográfico.

As frentes capitalistas modificam o meio natural ao produzir novas mercadorias globalizadas, fazendo avançar os espaços do agronegócio, das hidrelétricas, das madeireiras e das mineradoras (meio técnico e técnico-científico-informacional). Essa agenda territorial implica a transformação direta da sociabilidade dos povos da floresta, cujas solidariedades orgânicas são agora invadidas pelas solidariedades organizacionais do capital (Santos, 1996; Silva, 2014).

\footnotetext{
${ }^{1}$ Publicado em: CORREA, S. S; RIBEIRO, A. F. A; SILVA, R. G. C. A subjugação da força de trabalho quilombola ao capital na Amazônia: análise sobre o Quilombo Boa Vista no município de Oriximiná (Pará). Terr@ Plural (UEPG. Online), v. 9, p. 39-55, 2015.

https://orcid.org/0000-0002-4766-685X

** https://orcid.org/0000-0003-0731-9973

*** https://orcid.org/0000-0002-3348-9629
} 
$\mathrm{O}$ artigo analisa as transformações territoriais na comunidade quilombola Boa Vista, localizada às margens do rio Trombetas (Figura 1), no município do Oriximiná (Pará), que teve seu território "cercado" e restringido pelo capital mineral e o Governo Federal, representado pela territorialização da empresa mineradora Rio do Norte (MRN). O capital, ao se territorializar na região, submete a comunidade quilombola Boa Vista a uma relação desigual e dependente, mediante a metamorfose da forma de trabalho comunitária quilombola em trabalho assalariado, mediado pela contratação de serviços precarizados através da Cooperativa de Trabalho da Comunidade do Boa Vista (Cooperboa).

Figura 1 - Comunidades quilombolas em Oriximiná.

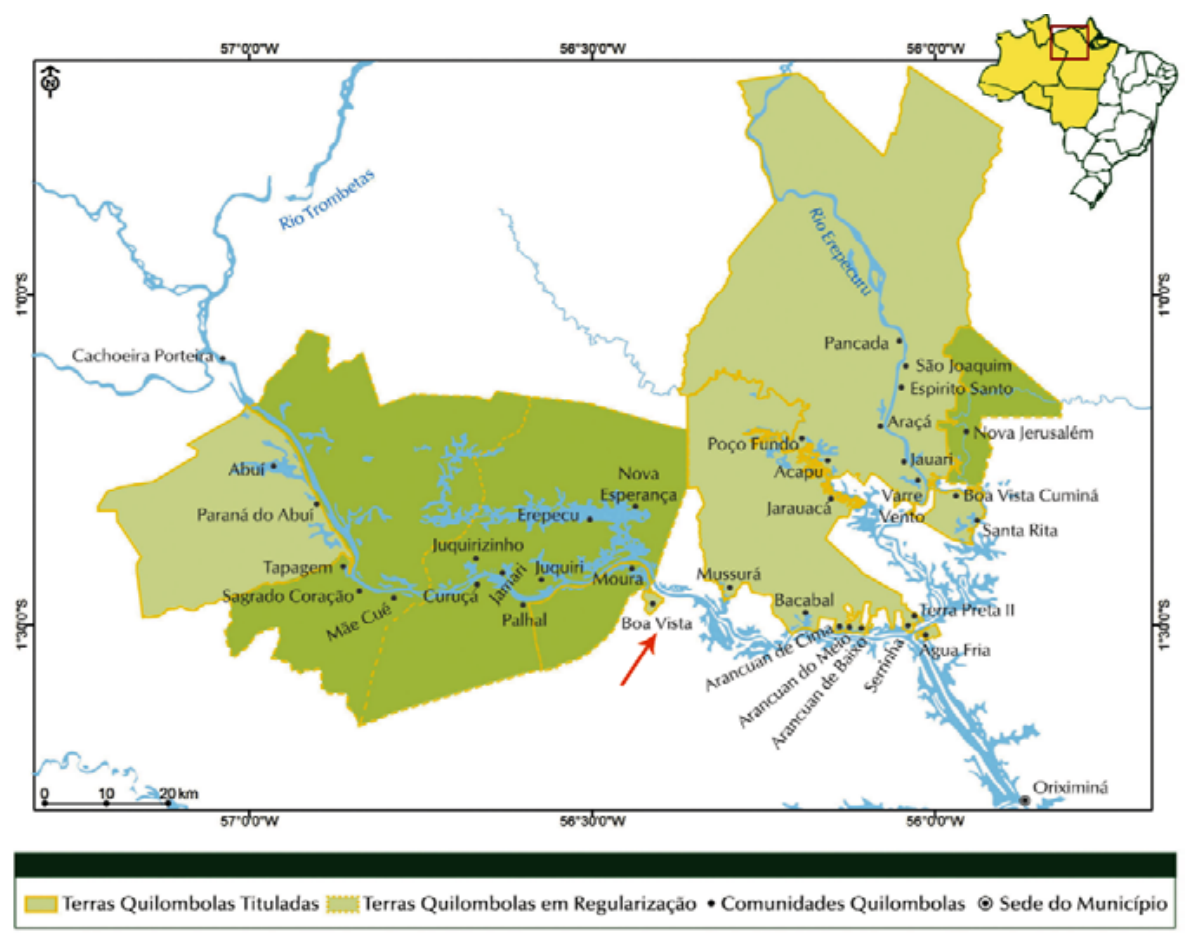

Fonte: CPI-SP, 2011.

Para este estudo foram realizados levantamentos bibliográfico e documental, trabalho de campo (realizado em dois períodos: 2 a 13 de dezembro de 2013 e 06 a 14 de junho de 2014) na Comunidade Boa Vista, na company town Trombetas, na Cooperativa de Trabalho 
da Comunidade do Boa Vista - Cooperboa e na Associação do Remanescentes de Quilombos do Município de Oriximiná (Arqmo).

Os resultados obtidos demonstram que quase $80 \%$ das famílias quilombolas da comunidade têm algum membro familiar prestando serviço para a mineradora através da cooperativa local, desempenhando funções de baixa remuneração (jardinagem, doméstico e auxiliar de serviços gerais). No trabalho assalariado, os quilombolas são desviados de suas práticas e costumes coletivos para a individualidade do trabalho assalariado. Nesse sentido, verifica-se a forte dependência da comunidade em relação à empresa mineradora, de onde são inseridos subalternamente no mundo do trabalho do capital. A pesquisa evidencia que a proximidade dos quilombolas com a empresa transformou a comunidade em uma "periferia urbana" da mineração, onde se tem acesso ao trabalhado assalariado (emprego), escola, hospital, lojas, etc., mas no seio de uma relação desigual, exploratória e, sobretudo, de alienação territorial.

\section{FORMAÇÃO DOS TERRITÓRIOS QUILOMBOLAS NO RIO TROMBETAS}

As comunidades quilombolas na Amazônia representam um importante conjunto de populações negras africanas, que foram "inseridas" na região como força de trabalho escravo nas fazendas de cacau, gado, engenhos e lavouras. No Pará, especialmente na região do Baixo Amazonas $^{2}$, o trabalho escravo cresceu acompanhado do desenvolvimento do comércio de cacau silvestre e cultivado, importante gênero de exportação do Grão-Pará entre 1773 e 1782. Assim, a introdução da força de trabalho negra na região do Baixo Amazonas, embora muitas vezes diminuída e até negada, foi bastante significativa para o desenvolvimento da economia regional e para a formação dos quilombos (Marin; Castro, 1995 e 1998).

Diante dos maus tratos e condições desumanas em que eram submetidos pela sociedade escravocrata, os quilombos constituíram-se em território, base de resistência e liberdade dos negros escravizados. As rotas de fugas empreendidas pelos escravos, em função da coerção física

${ }^{2}$ O Baixo Amazonas compreende a região oeste do Estado do Pará, abrangendo os municípios de Óbidos, Oriximiná, Prainha, Santarém, Terra Santa, Alenquer, Almeirim, Belterra, Curuá, Faro, Juruti, e Monte Alegre, entrecortada pelos rios Amazonas e Tapajós. 
e da exploração excessiva, eram favorecidas pela imensidão da floresta e da rede hidrográfica amazônica, onde encontraram abrigo e refúgio ocasionando a formação de inúmeros quilombos. Esses quilombos foram fortemente reprimidos e destruídos, entretanto, na região do rio Trombetas, devido ao encachoeiramento dos rios, a dificuldade de acesso e certo isolamento geográfico, os negros fugitivos conseguiram organizar um dos maiores quilombos da Amazônia ${ }^{3}$.

Segundo Vicente Salles (1971), entre os séculos XVIII e XIX os principais mocambos ${ }^{4}$ da Amazônia situavam-se no Grão-Pará, hoje atual estado do Pará, especialmente: no rio Trombetas, em Oriximiná; rio Curuá, em Alenquer; rio Anajás, no Marajó; margens do Tabatinga, em Cametá; no Alcobaça, atual Tucuruí; margens do rio Guamá, Moju, Capim (Caxiú), Mocajuba (litoral atlântico); e em Gurupi (divisa entre Pará e Maranhão), conforme demonstra a Figura 2.

\footnotetext{
${ }^{3}$ Os quilombos do rio Trombetas eram considerados os 'Palmares' amazônicos e estima-se que tenham abrigado mais de 2 mil indivíduos, originários do reagrupamento dos quilombos Inferno e Cipotema, destroçados, em 1812, pela expedição punitiva no rio Curuá em Alenquer (Wanderley, 2006; Salles, 1971; Andrade, 1995; Marin; Castro, 1998).

${ }^{4}$ Termo utilizado no século XIX por governadores e corpos de policiamento para identificar o agrupamento de fugitivos, formado notadamente por escravos (Marin; Castro, 1998).
} 
Figura 2 - Localização dos principais quilombos do Grão-Pará, formados nos séculos XVIII e XIX.

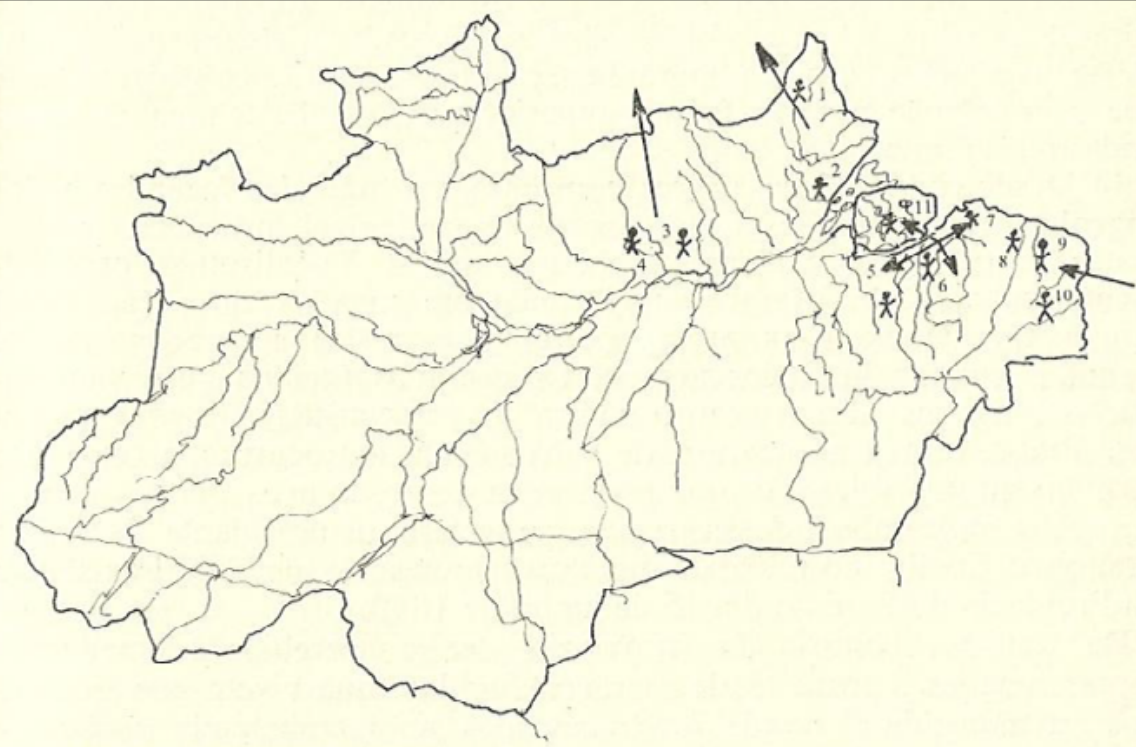

1. Amapá: Oiapoque-Calçoene.

2. Amapá: Mazagão.

3. Pará: Alenquer (rio Curuá).

4. Pará: Óbidos (rio Trombetas/Cuminá).

5. Pará: Alcobaça (hoje Tucuruí)/Cametá (rio Tocantins),

6. Pará: Caxiú (rio Moju/Capim).

7. Pará: Mocajuba (litoral Allântico do Pará).

8. Pará: Gurupi (atual divisa entre Pará e Maranhão).

9. Maranhão: Turiaçu (rio Maracassumé).

10. Maranhão: Turiaçu (rio Turiaçu).

11. Pará: Anajás (Lg. Mocambo, ilha de Marajó).

Fonte: Salles, 1971.

Os negros se refugiavam nos quilombos movidos pela necessidade e sonho de liberdade, dado a sua condição desumana na sociedade escravocrata brasileira em que eram socialmente considerados como uma mercadoria, sujeita às vontades e às leis dos seus senhores. A Figura 2 aponta os vários agrupamentos de negros que em resistência ao regime escravo se aquilombavam em lugares distantes e de difícil acesso em meio à floresta. Os quilombos do rio Trombetas resistiram à escravidão e às viagens punitivas, representando atualmente importantes territorialidades quilombolas, totalizando 35 comunidades, distribuídas ao longo do rio Trombetas e seus afluentes, no município de Oriximiná, oeste do estado do Pará. 
As comunidades quilombolas do Trombetas desenvolveram na floresta, nos rios e nas relações de parentesco toda uma organização social e territorial baseada na coletividade, no extrativismo, nas trocas com os grupos indígenas e nos saberes elaborados sobre a natureza, contribuindo para com sua reprodução social e cultural. Até meados da década de 1960, os negros ocupavam "livremente" as áreas do alto e médio rio Trombetas, com autonomia comunitária e organizados segundo regras coletivas, vivendo da caça, pesca, pequena agricultura e extrativismo da castanha, açaí, óleos vegetais, resinas, madeira, cipós, etc., estando livres com seus instrumentos de trabalho e experimentavam um espaço-tempo modulado pelos regimes da natureza. Assim, o tempo da caça, da pesca, da coleta e das festas eram tempo-espaço regidos pelas dinâmicas naturais.

Os territórios quilombolas foram se consolidando ao longo do Trombetas, em terras de uso comum, controlados pelos próprios sujeitos coletivos no seio de uma relação de pertencimento e de uso do espaço natural apenas como sobrevivência e reprodução dos grupos sociais ali territorializados. O trabalho era desenvolvido para garantir o sustento familiar e as festas coletivas. Nos quilombos se produziam os utensílios de barro, fogão à lenha, as tecelagens de palha para as moradias, paneiros, instrumentos para a caça e pesca e os rituais de crença e de curas combinando as plantas com os saberes desenvolvidos e herdados.

A partir da década de 1960, os espaços dos quilombolas do Trombetas sofreram profundas transformações com o processo de territorialização do capital, subsidiado pelo Governo autoritário, visando à exploração mineral, e em 1971 se instala no interior das comunidades quilombolas o Projeto Trombetas, cujo objetivo era extrair o minério de bauxita através da Mineradora Rio do Norte (MRN). Emergem os conflitos engendrados pelas contradições no uso do território, que de um lado se forma o território do capital, com sua rede de relações de produção, baseados na produtividade, no lucro, na tecnologia e na exploração intensiva da natureza e do homem e, de outro, o território dos quilombolas, com suas tradições, raízes, costumes, tendo na natureza o valor de uso e reprodução familiar.

A concepção de território na perspectiva crítica deve ser compreendida à luz da dialética, como uma síntese contraditória da totalidade das relações de poder e relações sociais, materializadas espacialmente, em que o Estado desempenha a função de mediador de interesses sociais conflitantes. $\mathrm{Na}$ questão em análise, nas lógicas diferenciadas de produção e reprodução do território emergem novas configurações territoriais, sociais, culturais e econômicas. Fernandes (2001) aponta que 
das relações contraditórias do capital desdobram-se disputas políticas, ideológicas e estratégias de dominação que ensejam diferentes projetos de desenvolvimento territorial, econômico, social e político. O território assim substanciado por desigualdades, diferenças, conflitos e contradições se apresenta como campos de poder (Raffestin, 1993).

O território reflete as tramas e os processos de dominação e de apropriação nas relações sociais, econômicas e políticas dos diferentes agentes sociais que produzem e controlam o território, fazendo uso de diversos meios e instrumentos, inclusive a força, resultando em conflitos, embates e disputas. Souza (2005) aponta que o território constitui um campo de forças, cujos agentes buscam o controle territorial, aflorando as contradições no uso da terra e da natureza no processo de acumulação do capital. Esse campo de poder se constitui por redes de relações que se articulam nas mais diversas escalas geográficas (Haesbaert, 2004).

\section{REPRODUÇÃO DO CAPITAL, TRABALHO E NATUREZA NO TERRITÓRIO QUILOMBOLA}

Para que possamos compreender a reprodução do capital mineral na floresta amazônica, além do manejo dos fatores de produção, torna-se necessário analisar a metamorfose social induzida pelo capital na comunidade quilombola Boa Vista, transposto no metabolismo social da condição de trabalho coletivo extrativo para o trabalho assalariado, subjugando sua força de trabalho e constituindo, assim, numa das principais transformações impostas pela presença do capital em relação aos quilombolas.

Nessa perspectiva, o capitalismo vem impondo sua lógica na floresta e desse modo tem subordinado o arranjo da produção, a divisão do trabalho e as relações de trabalho, desorganizando e reproduzindo novos territórios, que nesse caso é o território do capital e da sociabilidade capitalista. A metamorfose da comunidade quilombola, que se caracteriza pelo trabalho coletivo extrativista, para a forma trabalho assalariado, na medida em que as atividades que os qualifica como extrativista agora são substituídas pela relação capital e trabalho no âmbito do território do capital, cria uma nova dependência sob o domínio do capital. Os quilombolas deixam de viver exclusivamente dos recursos de seu território para vivenciar a modernização capitalista na floresta, dada a metamorfose da natureza em mercadoria (a extração da bauxita) e a emergência do trabalho assalariado. Isso amplia o espaço das forças produtivas (capital, tecnologia, força de trabalho) e a transformação 


\section{Geografia, território e sociedade na Amazônia}

das relações de produção nas áreas em que, numa perspectiva miltoniana, poderíamos qualificar de meio natural, mas que contemporaneamente modifica-se em meio técnico com a expansão do espaço do capital (Santos, 1996).

As relações de produção são, na essência, relações estabelecidas entre os homens no processo de produção social. São, portanto, relações sociais de produção. Essas relações constituem o núcleo do processo produtivo e Marx, em sua concepção histórica, sustenta isso afirmando que determinado modo de produção é condicionado pelas relações existentes, em cada época, entre o desenvolvimento das forças produtivas e as relações de produção (Ianni, 2005; Konder, 2009). No modo de produção capitalista a força de trabalho é uma mercadoria especial, pois possibilita a geração de outras mercadorias que serão trocadas por dinheiro, engrenando o lucro aos capitalistas detentores dos meios de produção. Ainda, segundo Ianni (2005, p. 133), “a intensificação da força de trabalho rouba do trabalhador o tempo livre que dispunha para se dedicar às suas culturas particulares de subsistência", o que nos permite associar que os quilombolas transformam-se progressivamente em trabalhador assalariado, mas, todavia, permanecem com a propriedade coletiva do território e com a possibilidade ainda de extração dos recursos desse território (caça, pesca, coleta de frutos, etc.).

Atualmente, com a territorialização da mineradora em áreas próximas aos territórios quilombolas, essa liberdade está sendo ideologicamente amputada pelo mecanismo da proletarização, via 'engenho' subliminar e oculto da subjugação da força de trabalho dos quilombolas à lógica capitalista de produção, que tem por objetivo a obtenção do lucro através da exploração da força de trabalho. Nessa perspectiva, podemos elucidar que o modo de produção capitalista expande-se sobre o território quilombola, impondo suas relações de produção, (re)produzindo um espaço fragmentado e articulado, materializando essa lógica de produção mediante a subjugação da comunidade quilombola à condição de mão de obra assalariada, essencial para a reprodução ampliada do capital. Portanto, a reprodução do capital não se prende somente à expropriação dos quilombolas de seu território, e sim, à dependência criada na apropriação da força de trabalho, que será capitalizada através do processo ideológico da subjugação do quilombola aos ditames do capital, por meio da dominação de sua energia corpórea e mental.

Segundo Oliveira (1998) o capital desenvolveu liames de subjugação que funcionam como peias, como amarras aos camponeses e aos demais segmentos sociais que atualmente se denomina "povos da floresta", transformando relações não capitalistas em relações capitalistas 
de produção, que força esses segmentos a atender a lógica da geração de lucro para o capital. Depreende-se daí o que seria essencial para a reprodução do capital - a separação do trabalho e dos meios de produção - não se constitui como a única condição de acumulação do valor. Ocorre a apropriação da mais-valia produzida pelos quilombolas sem a necessária expropriação de seu território e esse mecanismo de apropriação da riqueza que os aliena deve-se à subjugação da força de trabalho ao capital mineral.

Na comunidade quilombola Boa Vista é comum perceber, a partir das falas dos trabalhadores, que a empresa Mineração Rio do Norte (MRN) é a "tábua de salvação" que possibilita sua sobrevivência através da oferta de emprego, onde o preço pago pela força de trabalho é justo e coerente com a função desempenhada. Assim, essa relação de troca é estruturada de forma combinada, aparentemente equitativa, porém, na realidade é desigual, tendo em sua essência a exploração, em que o capital se apropria do valor produzido sob a forma de lucro, pagando ao trabalhador apenas uma fração mínima do valor produzido em forma de salário, para que esse possa se reproduzir apenas enquanto trabalhador e se perpetue nesta condição de vendedor de mão de obra produtiva, barata e altamente dependente.

No nível ideológico, é essa relação social, produtiva e mercantilizada, pautada no império do valor da troca a base da metamorfose do quilombola (extrativista) em proletariado (trabalho assalariado). Desta forma o capital produz através do instrumento ideológico da alienação a ilusão de que o trabalhador quilombola necessita trabalhar, de que deve vender sua mão de obra e receber um salário que possibilitará as conquistas de itens básicos para sua sobrevivência, tornando-se o elo mais vulnerável na cadeia do sistema produtivo, em que o produto do seu trabalho é repartido entre os diversos elementos do sistema capitalista mundial.

Podemos constatar que o trabalho assalariado se constitui em um mecanismo estruturante dentro da lógica capitalista e a intensificação das relações de trabalho ocorrem dentro de um processo de modificação dos valores culturais e sociais na comunidade quilombola. A subjugação é um instrumento ideológico da lógica capitalista, sendo oculto, pois é visto como um mecanismo natural, que tem como objetivo a benfeitoria da promoção do desenvolvimento, inserindo no mundo do trabalho uma comunidade quilombola que necessitaria de trabalho para sobreviver em seu próprio território. Por isso a subjugação da força de trabalho imbricado com a alienação do território pode e deve ser descortinada, dado que reproduz um círculo vicioso de "apadrinhamento", onde os 
trabalhadores quilombolas veem-se como devedores e dependentes em relação ao patrão, no caso, a Mineradora Rio do Norte (MRN).

QUILOMBO BOA VISTA E MINERAÇÃO RIO DO NORTE (MRN): TRANSFORMAÇÕES NAS RELAÇÕES SOCIEDADE-NATUREZA-TRABALHO

A comunidade quilombola Boa Vista tem sua espacialidade construída pela descida das "águas bravas”, localizadas no alto rio Trombetas, com trechos encachoeirados e de difícil acesso, para áreas mais próximas da cidade de Oriximiná. De acordo com os quilombolas entrevistados, o nome Boa Vista advém da boa visibilidade do rio e da floresta, uma vez que se encontra no alto de um barranco, permitindo a vigilância e uma visão privilegiada (Figura 3). No primeiro plano, tem-se um barco e casas dos quilombolas. No segundo plano, a presença de grandes navios para o transporte de bauxita. 
Figura 3 - Vista a partir do "alto do barranco", no quilombo Boa Vista.

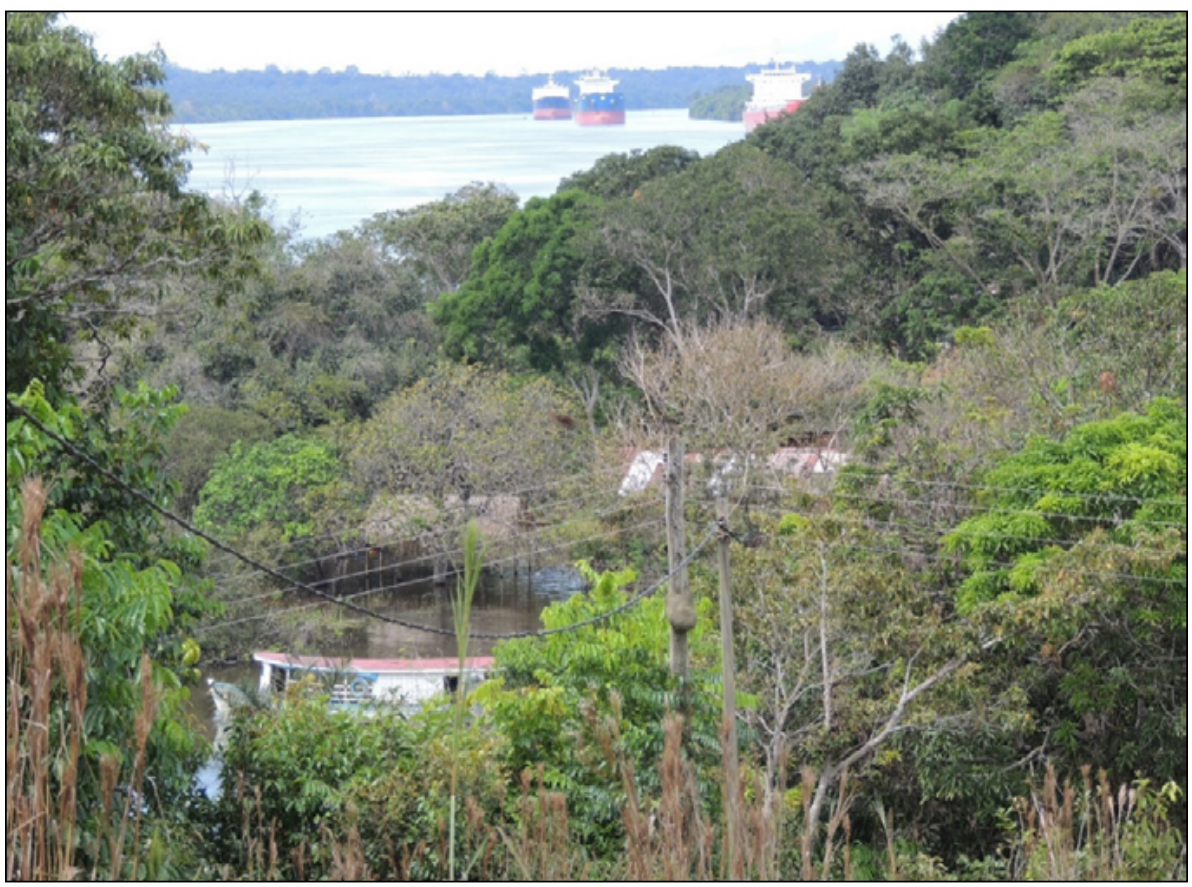

Fonte: Trabalho de Campo, 2014.

Acevedo e Castro (1998, p. 215) explicam que a formação do povoado Boa Vista surgiu com o deslocamento de membros de famílias quilombolas que moravam na Comunidade da Tapagem e escolheram o local entre o Igarapé da Água Fria e a entrada do Lago do Moura para fixarem residência, inclusive, de acordo com as autoras, esse local possuía registro cartorial feito em nome de Claudino Bentes da Conceição. Nesse território os quilombolas desenvolveram suas relações sociais e de vizinhança, beneficiando-se da riqueza dos castanhais, do extrativismo e da agricultura de subsistência.

A instalação da Mineradora Rio do Norte, em meados da década de 1970, altera substancialmente as articulações das comunidades quilombolas, provocando exclusões, conflitualidades, violência e dominação na região do rio Trombetas. O avanço do capital em espaços periféricos além de transformar as relações preexistentes, tornam esses lugares, antes "invisíveis" ao Estado e mesmo à sociedade envolvente, em espaços "visíveis" à reprodução do capital nacional e internacional, mas que são estranhos aos interesses dos sujeitos locais. Esses interesses estão 


\section{Geografia, território e sociedade na Amazônia}

articulados a uma rede de investimentos que propiciam a reprodução do capital se apropriando dos recursos naturais, base da existência de populações que têm na floresta seu principal meio de reprodução social e territorial, como os quilombolas.

O capital mineral, ao se instalar no território quilombola Boa Vista, se apropria das áreas de roça, pesca, caça e extrativismo quilombola. Além disso, introduz a institucionalização de órgãos públicos e empresas privadas na região para atender ao projeto, normatizando segundo seus interesses um conjunto de regras e leis no território, a exemplo a instalação das empresas Jari, Petrobrás, Andrade Gutierrez e de bases de órgãos como IBDF/Ibama e Exército Brasileiro. Nesse contexto, expropriação, violência, ameaças e restrições aos quilombolas foram marcas deixadas no processo de territorialização da MRN no Trombetas. Contraditoriamente, a comunidade Boa Vista, a mais ameaçada pelo projeto, apoiada pela Igreja Católica e pela criação da Associação dos Remanescentes de Quilombo do Município de Oriximiná (Arqmo), amparada no artigo 68 (ADCT) da Constituição Federal, consegue em 1995 a Titulação de parte do seu Território ${ }^{5}$, ou seja, duas décadas depois da territorialização do capital mineral em seu território.

Desse modo, a Comunidade Boa Vista se vê cercada pelo território da mineradora de um lado, e de outro pela criação no entorno de Unidades de Conservação, o que lhe impede de reproduzir-se a partir do trabalho extrativo (caça, pesca e coleta). Assim, uma das formas de resistir no território quilombola foi submeter sua capacidade laboral ao capital mineral, uma vez que as áreas onde realizavam o extrativismo foram apropriadas pelo Projeto Mineral, ou seja, houve um cercamento e diminuição de seu território. Em 4 de julho de 1996, com o apoio da empresa, cria-se a Cooperativa de Trabalho da Comunidade do Boa Vista (Cooperboa), com o objetivo de prestar serviços diversos para a company town Trombetas e a atividade mineradora (ver Figura 4). Os cargos contratados pela mineradora, através da cooperativa, foram e continuam sendo basicamente nas atividades de zeladoria, auxiliar de serviços gerais, serviços de campo, operador de roçadeira, operador de máquina roçadeira lateral e motorista de veículos leves.

\footnotetext{
${ }^{5}$ A comunidade quilombola Boa Vista, foi a primeira no Brasil a receber titulação coletiva de suas terras. No dia 24/11/1995, a União Federal e o Instituto Nacional de Colonização e Reforma Agrária (Incra), outorgaram à Associação da Comunidade Remanescente de Quilombo Boa Vista (ACRQBV), a titulação coletiva de uma área de $1.125,0341$, o que não representou a incorporação das áreas onde realizavam o extrativismo, roças comunitárias, caça e pesca.
} 
Figura 4 - (A) Escritório administrativo da Cooperboa, na área da company town Trombetas. (B) Trabalhador Quilombola prestando serviço à Mineradora na função de auxiliar de serviços gerais (ASG), na parte do Horto do Projeto.

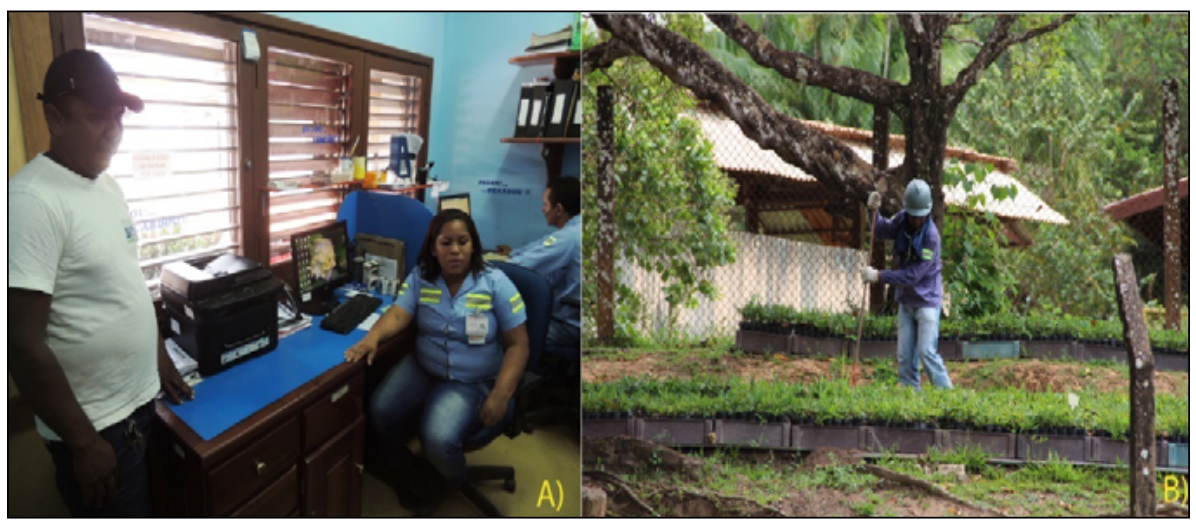

Fonte: Trabalho de Campo, 2014.

Os quilombolas do Boa Vista, através da cooperativa, passaram então a submeter sua força de trabalho ao capital mineral e tal processo veio acompanhado de um conjunto de transformações na cultura, nos costumes e no cotidiano dos quilombolas. Envolvidos pela ilusão do consumismo e dos novos valores ideológicos advindos com o projeto, os quilombolas se inserem subalternamente numa rede de relações externas, desviando de suas raízes e costumes, como podemos observar nesta entrevista:

Antes todo mundo, um ajudava o outro, a gente fazia serviço um pelo outro, serviço, comunitário, mutirão todo mundo ia, hoje ninguém não vai, se tu não pagar não tem quem trabalhe pra ti, então isso daí não muda, essa é uma situação que foi eles [se referindo a Empresa Mineradora (MRN)] que trouxeram pra cá, que antes não era desse jeito. Então hoje ninguém num faz nada pra outras pessoas aqui de graça, qualquer coisa que tu peça pra alguém fazer pra ti, ele vai te cobrar, então isso foi uma das coisas que mudou e que não tem como voltar a atrás, a cultura acabou tudo. Não existe mas nada..., quando eu me entendi a minha vó tinha roça, todo mundo fazia roça, farinha, agora tudo é comprado, eles acabaram com tudo.

Entrevistado I, barqueiro, quilombola do Boa Vista. 


\section{Geografia, território e sociedade na Amazônia}

O processo de proletarização dos quilombolas mostra o quão destrutivo é o avanço do capital em territórios não capitalistas, já que contraditoriamente além de expropriar, monopolizar e subjugar as suas racionalidades, induz também a ideia do "moderno", do novo, da individualidade, do consumismo, criando e multiplicando os territórios de dependência. Assim, transforma a comunidade quilombola em "sobrantes", verdadeiros exércitos de reserva na floresta, submetidos ao trabalho de baixa qualificação já que os torna ao mesmo tempo supérfluos e descartáveis, em funções laborais que exige pouca qualificação e nível de escolaridade.

A perda da autonomia e liberdade de trabalho para o capital implica também a alienação e acomodação no território, uma vez que a jornada de trabalho assalariado e o tempo do capital absorve a capacidade criadora e organizativa do quilombo. Desse modo ocorre o processo de fragmentação dos quilombolas, que não conseguem se fortalecer internamente em suas organizações políticas, tornando-se vulneráveis e passando, inclusive, a reproduzir o discurso do capital. A produção desigual do território capitalista evidencia como o avanço capitalista na floresta redefine os territórios, sujeitando as populações a diferentes e contraditórias relações, além de estruturar, desarticular e hierarquizar as forças locais ao seu processo de dominação e hegemonia. Nessa perspectiva, pouco se questiona a ordem e a lei do capital, ficando esses papeis restritos aos mais idosos e a algumas lideranças, que veem toda a sua história, resistência e raízes serem desviadas para os novos valores promovidos pelo capital, colocando em risco a perda do vínculo com o território, esse conquistado na luta política.

Quando a mineração fechar as portas aqui pra nós, o que vai acontecer é que a comunidade vai dar as suas terras pro o povo de fora, e vão embora pra cidade, a maioria do pessoal vão embora pra cidade vão deixar seus terrenos seus lugares e depois vão se arrepender e vai ser tarde demais. Porque eu, meu marido e mais uns poucos, sabe mexer com a terra, sabe mexer com a roça, sabe plantar, sabe colher, só que essa juventude hoje não sabe nada, tá sendo ensinado outras coisas”.

"Hoje aqui na comunidade Boa Vista não tem pessoas pra se destacar, pra correr atrás numa reunião, pra ouvir, pra reivindicar não tem..., só é: eu estou ocupado, eu tô trabalhando, eu 


\section{A subjugação da força de trabalho quilombola ao capital na Amazônia}

tô no meu emprego, eu tô bem no meu emprego e acabou-se, sabe.. aquela coisa assim. Se eu tô trabalhando, eu tô bem no meu emprego, eu tô ganhando 3 mil reais, eu não tô nem aí, que o povo da comunidade se lasque, não tô nem aí com o resto".

Entrevistado II, 59 anos, quilombola da Comunidade Boa Vista.

Conceição (1991) explica que a expansão do capital se faz de forma desigual e contraditória, através da transformação do camponês em trabalhador assalariado e a subordinação deles na terra sem serem expulsos. Essa situação parcialmente ocorre no quilombo estudado, uma vez que parte do território quilombola foi apropriada com a territorialização da mineradora e a outra parte, aparelhada pelo Estado, foi titulada em nome dos quilombolas que tiveram, pela pressão territorial, que se metamorfosear de extrativista em trabalhador assalariado, via cooperativa de trabalho. Nesse caso, como o capital não pôde se apropriar de toda a terra quilombola, transformou a força de trabalho disponível, convertendo-os em "proletários da floresta". Assim, despossuídos das suas áreas extrativas, os quilombolas se veem obrigados a trabalhar como diaristas e assalariados, formando uma massa precarizada, submetida às imposições do capital, tirando-os sua autonomia e resistência.

O controle do capital sobre esses territórios na Amazônia é apoiado pelo aparelho do Estado e suas políticas desenvolvimentistas, colaborando com a manutenção do controle capitalista e a exploração dos recursos naturais, materializadas no 'consenso' do progresso econômico do país. A ordem espacial do capital se consolida à medida que os discursos hegemônicos condicionam a natureza e o trabalho sob o viés do lucro e da exploração da mão de obra. O capital, ao se apropriar dos meios de produção e da força de trabalho familiar, limita a reprodução desses grupos, pressionando-os de várias formas, inclusive expulsando-os para os espaços periféricos das cidades. Nas entrevistas realizadas no Boa Vista, com o desenvolvimento da atividade mineradora, muitas famílias se viram obrigadas a mudar para área urbana de Oriximiná e construir uma segunda moradia, inclusive como alternativa, quando demitidos pela empresa, ou finalizarem as atividades contratuais com a cooperativa.

O trabalho assalariado modificou as relações comunitárias e familiares dos quilombolas, uma vez que novos valores foram assimilados, especialmente pelos mais jovens, que passaram a ter acessos a 


\section{Geografia, território e sociedade na Amazônia}

aparelhos tecnológicos, influenciando nos costumes e hábitos tradicionalmente reproduzidos. Nas entrevistas foram relatadas as mudanças no comportamento dos jovens, que com frequência fazem uso de álcool, drogas, modas e ampliaram seus círculos de amizade, tendo maior acesso à informação e as conexões fora do quilombo. Essa situação está intimamente ligada ao fetichismo do consumo supérfluo de mercadorias e de valores externos à realidade das famílias. As famílias quilombolas passaram a ter acesso a crédito em lojas, via o uso do cartão de crédito e débito, passando a se endividar mais para adquirir mercadorias introduzidas pela sociabilidade do capital.

Nesse sentido, os mais jovens não são mais ensinados a cultivar suas raízes; são desviados desta e se apropriam da cultura capitalista, estranha a sua, mas que passa a ser assimilada sem objeções. $O$ trabalho com o artesanato, nas danças, nos rituais, na culinária típica, são atividades que não despertam mais interesse da juventude, e que passam a não ser mais reproduzidas, ficando limitados aos idosos e alguns poucos. Os jovens buscam novas atividades de lazer e trabalho na empresa. O fato de se tornarem assalariados já os diferenciam no sentido de adquirir bens e mercadorias que são utilizadas de forma individual, tornando-se mais desafiador a cooperação, o mutirão, a ajuda mútua, uma vez que agora assalariados, podem comprar e adquirir de forma privada seus bens de consumo. Portanto, torna-se evidente as transformações nas relações espaciais, sociais, culturais e de trabalho dos quilombolas com a territorialização do capital na floresta amazônica, revelando as lógicas desiguais de uso do território e as estratégias de reprodução do capital em espaços não capitalistas.

\section{CONCLUSÃO}

A subjugação da força de trabalho quilombola ao capital se realiza nas relações exploratórias do capital, galgadas na lei de valor de troca, em detrimento do valor de uso. Assim, transforma os territórios não capitalistas, inserindo-os na lógica do capital via subordinação da força de trabalho e do território. A transformação da força de trabalho quilombola em mercadoria aliena a visão totalizante do grupo sobre o seu território, ocasionando a perda de seus costumes e a desrealização coletiva do trabalho que o passa a ser aos ditames do capital mineral.

Os quilombolas desprovidos de seus territórios extrativos são envolvidos pela lógica da empresa mineradora, tendo como alternativa 
de sobrevivência no território a submissão do que ainda lhe resta, que é a sua força de trabalho em funções que a empresa dispõe. Ao se transformarem em trabalhadores assalariados e em função da jornada de trabalho se afastam da luta política, das organizações, como também dos costumes tradicionalmente vividos no cotidiano do grupo, antes da territorialização do capital.

Assim, o território do capital vai se configurando no seio de relações desiguais, conflitantes e contraditórias. Essas relações são engendradas por múltiplas relações de poder, envolvendo classes antagônicas, onde contraditoriamente para a expansão do capital, necessita-se da fragmentação, domínio e controle do outro.

\section{REFERÊNCIAS}

CPI-SP. Comissão Pró-Índio de São Paulo. Terras quilombolas em Oriximiná: pressões e ameaças. São Paulo: CPI-SP, 2011. p. 42.

HAESBAERT, Rogério. O mito da desterritorialização: do "fim dos territórios” multiterritorialidade. Rio de Janeiro: Bertrand Brasil, 2004.

IANNI, Octavio. A formação do proletariado rural no Brasil. In: STEDILE, João, P. (Org). A questão agrária no Brasil: o debate na esquerda 1960-1980. São Paulo: Expressão popular, 2005.

KONDER, Leandro. O marxismo na batalha das idéias. 2. ed. São Paulo: Expressão Popular, 2009. p. 200.

MAESTRI, Mario. A aldeia ausente: índio, caboclos, cativos, moradores e imigrantes na formação da classe camponesa brasileira. In: STEDILE, João, P. (Org). A questão agrária no Brasil: o debate na esquerda 19601980. São Paulo: Expressão popular, 2005.

MARIN, Rosa Acevedo; CASTRO, Edna. Grandes projetos e terras de negro: conflito e resistência no Trombetas. In: CASTRO, Edna; MOURA, Edila; MAIA, Maria Lúcia. Industrialização e grandes projetos: desorganização e reorganização do espaço. Belém: Editora da UFPA, 1995. p. 201-333

MARIN, Rosa Acevedo; CASTRO, Edna Ramos. Negros de Trombetas: guardiões de matas e rios. Belém: Cejup/UFPA-NAEA, 1998.

OLIVEIRA, Ariovaldo Umbelino. Modo de produção capitalista, agricultura e reforma agrária. São Paulo: Labur Edições, 2007, p. 184.

OLIVEIRA, Ariovaldo Umbelino. O campo brasileiro no final dos anos 80. Boletim Paulista de Geografia. São Paulo, n. 66, p. 5-22, 1998. 
RAFFESTIN, Claude. Por uma geografia do poder. São Paulo: Ática, 1993.

RAMOS FILHO, Eraldo da S. A ofensiva do capital no campo brasileiro e a resistência do campesinato. Revista NERA. Presidente Prudente: Ano 8, n. 6, p. 46-58, 2005.

SALLES, Vicente. O negro no Pará: sob o regime da escravidão. Rio de Janeiro: Fundação Getúlio Vargas; Universidade Federal do Pará, 1971.

SANTOS, Marleide M. Movimentos sociais: na trama subliminar do ocultamento dos conflitos de classe. 2008. 325 f. Tese (Doutorado em Geografia), Núcleo de pós-graduação em Geografia (NPGEO), Universidade Federal de Sergipe (UFS).

SANTOS, Milton. A natureza do espaço: técnica e tempo - razão e emoção. São Paulo: Hucitec, 1996. p. 208.

SILVA, Ricardo Gilson da Costa. Espaço, sociedade e natureza em Rondônia. Revista GeoAmazônia, Belém, n. 2, v. 1, p. 144-165, jan./ jun. 2014. 


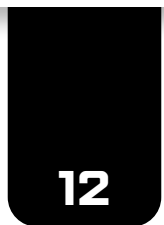

\section{RURALIDADES NA AMAZÔNIA: MATERIALIZAÇÕES NO ESPaÇo URbano DE Iranduba E Silves (AM)}

Matheus Pinto de Souza"

\section{INTRODUÇÃO}

As diversas transformações ocorridas no decorrer da história humana, impulsionadas pelo desenvolvimento e aprimoramento das técnicas, induziram diferentes mudanças na estrutura da sociedade, sobretudo a partir da revolução industrial, sendo acentuadas a partir do processo de globalização.

Em meio ao processo de mudança observado, o antagonismo representado pelos espaços urbano e rural se acirrou e com o crescimento das cidades, associado ao desenvolvimento do capitalismo as estruturas sociais, econômicas e políticas, passam por transformações significativas, havendo a necessidade de repensar suas relações.

Conceitualmente o espaço rural foi analisado, tendo como base principal, dados estatísticos sobre a população residente no campo bem como números referentes à produção agropastoril e nesse aspecto, no Brasil, o Instituto Brasileiro de Geografia e Estatística (IBGE) teve importante influência a partir de estudos desenvolvidos em todo o Território Nacional. Dessa forma, o rural fora quase sempre associado ao lugar da produção, de baixa densidade populacional e frágil infraestrutura, o lugar do atraso.

Em oposição, com as mudanças ocorridas a partir da industrialização brasileira o número de pessoas que deixaram o campo e passaram a residir nas cidades cresceu de forma exponencial, assim, o Brasil passa a se configurar como um país de população predominantemente urbana (Santos, 2013) e como consequência, as cidades passaram a ser sinô-

" https://orcid.org/0000-0003-3365-832X 
nimo do progresso, da modernidade, expandindo-se, emergindo assim grandes centros urbanos que se espraiaram, culminando na formação de regiões metropolitanas.

Nesse sentido, Região Metropolitana de Manaus (RMM) se difere em muitos aspectos das demais existentes no Brasil e no mundo. Isso exige que os modelos e formas de analisar os espaços rural e urbano sejam repensados e reorganizados, para que se possa apreender a totalidade das dinâmicas políticas, territoriais, econômicas e, sobretudo, sociais.

Assim, a partir da observação empírica, do levantamento e análise de dados, buscou-se identificar de que forma esse processo de reconfiguração do espaço impacta a vida cotidiana e as relações socioterritoriais nos municípios estudados. Entende-se, portanto, que por tratar-se da observação de fatos históricos que deram início aos fenômenos investigados, esse método elenca-se como o mais adequado para que chegássemos aos resultados pretendidos (Sposito, 2000; 2004).

Dessa forma, buscamos analisar a configuração do espaço urbano das cidades de Iranduba e Silves, ambas na RMM (Figura 1), identificando as práticas e costumes comuns a espaços rurais, que se perpetuam dentro do espaço urbano das cidades elencadas, como formas de evidenciar as resistências e mesmo permanências da vida cotidiana, práticas sociais e culturais do campo. Elencar estes dois municípios, dentro de um território tão amplo e diversificado, justificando-se pelas diferentes formas de interação que Iranduba e Silves mantém com a metrópole Manaus, onde fluxos e modais de transporte se diferenciam bruscamente de um para outro. 


\section{Ruralidades na Amazônia: materializações no espaço urbano de Iranduba e Silves [AM]}

Figura 1 - Área de estudo na Região Metropolitana de Manaus.

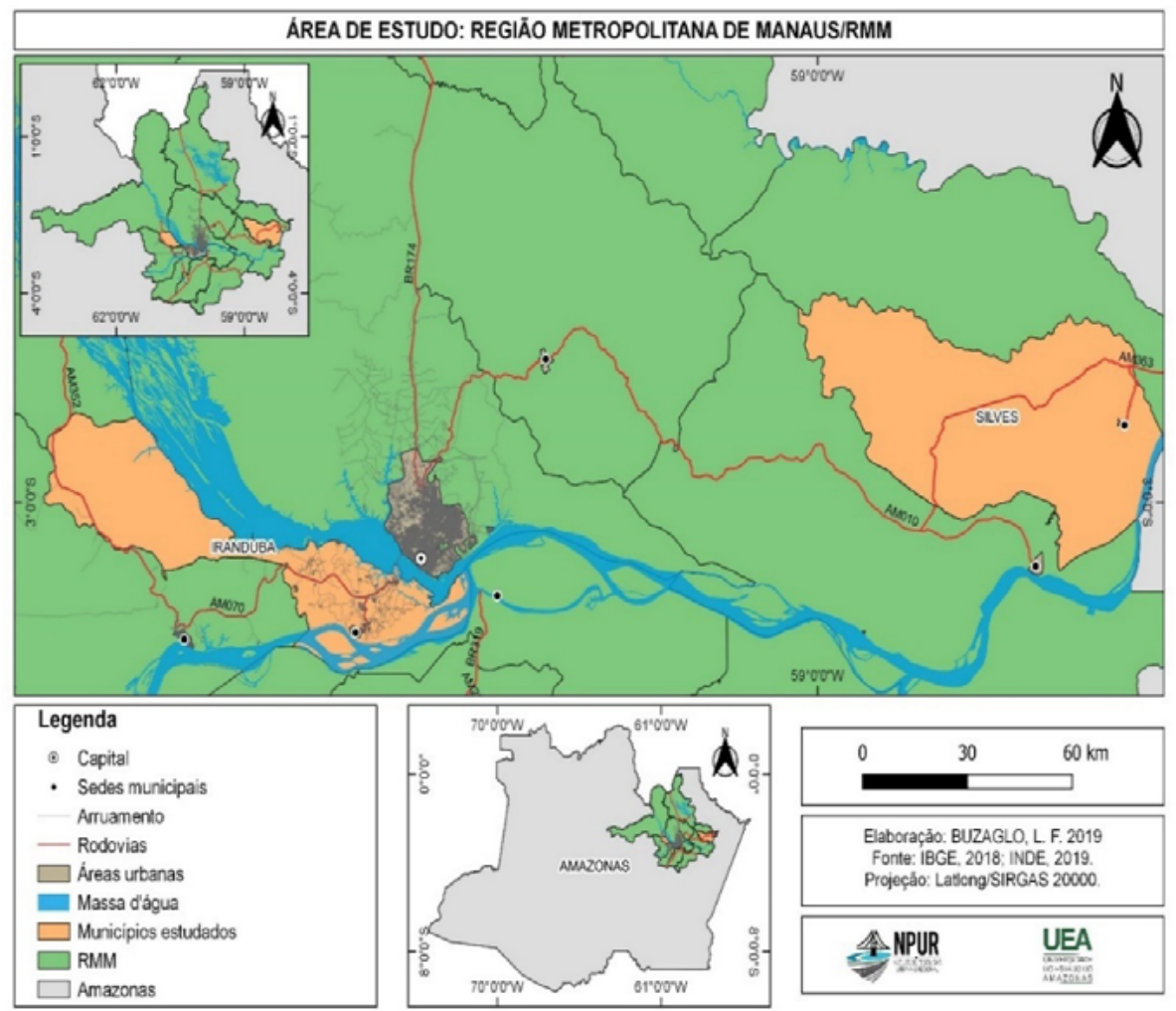

Fonte: IBGE, 2019; INDE, 2019. Org.: Buzaglo, L, F., 2019.

Para tanto, partimos da hipótese de que essa inserção de aspectos do urbano no rural, sobretudo a partir da elaboração dos planos diretores municipais, onde áreas de expansão incorporam espaços essencialmente rurais ao espaço urbano das cidades, ainda que proporcione uma mudança nas relações socioespaciais, não extingue por completo práticas e costumes comuns ao modo de vida rural.

Soma-se isso às peculiaridades e particularidades da região amazônica, onde as dinâmicas urbanas e rurais diferem-se das demais regiões do país, sendo o modo de vida do amazônida repleto de unicidades indutoras dos processos sociais e territoriais observados. 


\section{Geografia, território e sociedade na Amazônia}

Desta forma, no presente trabalho, compreende-se a Ruralidade como resultante do processo de reestruturação da sociedade, através de processos de reterritorialização (Haesbaert, 2004) onde as práticas e vivencias do rural se perpetuam na cidade (Rua, 2006; Lefebvre, 2001) bem como através da ocorrência de "geossímbolos", assim descritos por Floriani et al. (2017) como sendo fragmentos materiais e imateriais do rural em essência considerando ainda hábitos e costumes que fazem parte do cotidiano dos que vivem na região.

\section{Metodologia}

O rigor metodológico é, para a ciência, a chave para desvendar os mistérios do mundo e, como bem colocou René Descartes (1983) em seu Discurso do Método, até os mais competentes podem cair em erro se não seguirem cada passo - da pesquisa - com o máximo rigor já que "não basta ter o espírito lúcido, o principal é aplicá-lo bem" (Descartes, 1983, p. 29).

Entendemos, portanto, que toda investigação deve ser bem elaborada e planejada de forma precisa, sendo cada passo pensado e programado minimamente, com o intuito de antever ao máximo os infortúnios que eventualmente possam surgir neste percurso. Seguindo essa lógica, para a presente análise observou-se, em primeiro lugar, o crescimento espraiado das cidades, processo que altera as estruturas sociais e territoriais, surgindo assim as seguintes indagações: como estes "novos espaços" se estruturam a partir desta nova lógica de reprodução socioespacial? E, a partir disto, quais as práticas do rural que ainda se perpetuam, agora no urbano, como resultado desse processo de des/re/territorialização? Processo que, no presente estudo, é compreendido conforme Haesbaert (2004), como consequência das mudanças socioespaciais ocorridas a partir de ações dos agentes hegemônicos.

Destarte, a presente análise, por valer-se de dados qualitativos sem, contudo, desprezar dados quantitativos - utilizados para formular e reforçar análises qualitativas conforme contexto ou recorte da realidade estudada - recorreu-se ao método Histórico-Crítico-Dialético, pois, segundo Sposito (2000) esse método leva em conta a ideia de movimento e transformações que, ao serem observadas pelo pesquisador, podem ser analisados de forma crítica e indutiva.

Portanto, no nível epistemológico, o materialismo histórico vale-se de processos históricos que deram origem aos fenômenos investiga- 


\section{Ruralidades na Amazônia: materializações no espaço urbano de Iranduba e Silves [AM]}

dos, utilizando-os como atribuidor de consenso na relação entre homem e natureza (Sposito, 2004), perscrutando essa relação como forma de obter elementos para a compreensão das transformações na sociedade, observando ainda a relação sociedade/natureza como processo pelo qual o homem influencia o meio e é por este influenciado (Santos, 2006).

Já no nível ontológico, conforme afirma Sposito (2000) tem-se que "o homem é concebido como um ser histórico e social, determinado por contextos econômicos, políticos e culturais, criando e transformando sua realidade social como essência" (Sposito, 2000, p. 357) estando, portanto, sujeito e objeto, dispostos de forma dinâmica, tornando-se possível a compreensão da realidade observada no tempo-espaço.

Contudo, sendo a geografia uma ciência que busca a compreensão dos processos empreendidos pela sociedade e espacializados no meio em sua totalidade, corroboramos com Alves (2008, p. 228) ao inferirmos que é "o método que se ajusta com fenômeno, e não o fenômeno que se ajusta com o método" o que subsidia o uso dos discursos e relatos dos agentes sociais envolvidos como forma de reforçar os resultados obtidos por entendermos que a materialidade dos processos investigados - as ruralidades presentes nas cidades de Iranduba e Silves - encontra-se presente na oralidade dos sujeitos, tornando possível compreender "como são engendradas as práticas materiais e simbólicas de apropriação do espaço por uma dada coletividade" (Floriani, 2017, p. 166).

No que se refere aos passos procedimentais, recorreu-se primeiramente ao levantamento e revisão bibliográfica pois esta ferramenta da pesquisa segundo Marconi e Lakatos (2008) é fundamental para qualquer investigação, visto que a leitura de material já produzido favorece a obtenção e a apropriação de informações pré-existentes sobre o tema que se pretende pesquisar, poupando tempo e tornando mais objetiva a pesquisa de campo.

Sendo assim, no que concerne à seleção e consulta à bibliografia, Moresi (2003), afirma que além de ser instrumento basilar da pesquisa, fornecendo conhecimento prévio do assunto, permite mapear autores em que serão ancoradas as análises, ou seja, trata-se da construção da base teórica do trabalho o que segundo Luna (1997) apud Moresi (2003) se dá essencialmente tendo como objetivo os seguintes pontos:

- determinação do 'estado da arte': o pesquisador procura mostrar através da literatura já publicada o que já sabe sobre o tema $[. .$.$] - revisão teórica: você insere o problema de pes-$ 
quisa dentro de um quadro de referência teórica para explicá-lo [...] - revisão empírica: você procura explicar como o problema vem sendo pesquisado do ponto de vista metodológico [...] - revisão histórica: você busca recuperar a evolução de um conceito, tema, abordagem ou outros aspectos (Luna, 1997, apud Moresi, 2003, p. 25, grifo do autor).

Desta forma, optou-se por fazer uma revisão teórica mais ampla, visto que o fenômeno que se pretendeu investigar pode ser explicado não apenas por uma teoria, mas por diferentes abordagens, englobando análises da geografia, filosofia, sociologia, exigindo-nos a estruturação e a construção de relações entre as teorias elencadas, que nos conduziram à identificação de contrapontos entre ruralidades e urbanidades, apontando para o devir rurbano - espaço hibrido, onde o habitar mescla práticas e estruturas dos espaços urbano e rural, simultaneamente (Floriani et al., 2017).

Por fim, tendo como base o arcabouço teórico construído, buscou-se identificar quais aspectos da ruralidade - formas de produção, reprodução e transformações socioespaciais - encontram-se materializados a partir do contexto urbano dos municípios de Iranduba e Silves e para tanto, foram elencados alguns elementos - materiais e imateriais - a serem observados em campo, sendo estas variáveis importantes dado o encadeamento representado pelo rural no rural e o rural no urbano, como materialidade e subjetividade do "processo de recriação do espaço vivido e coabitado de outrora em outras regiões rurais antes do novo processo modernização que gerou a proletarização camponesa e consequente êxodo para os centros urbanos" (Floriani et al., 2017, p. 166, grifo nosso).

As variáveis analíticas elencadas foram pautadas na identificação de elementos presentes na paisagem urbana e que remetem ao espaço rural, como perfil das residências, disposição das varandas, mobiliários, ferramentas, fogareiros a lenha, rádio a pilha, cultivos de hortaliças e criação de animais nos quintais, como galinha, pato e porco para consumo e/ou comercialização, bem como de aspectos da reprodução social, característicos do meio rural e que se perpetuam nas cidades elencadas, como a ocorrência de trocas entre vizinhos, de serviços e produtos; organização familiar, divisão de tarefas diárias, lida com a plantação e com os animais, bem como hábitos do dia a dia econômicos, alimentares e de lazer. 


\section{Ruralidades na Amazônia: materializações no espaço urbano de Iranduba e Silves [AM]}

Posteriormente, com as atividades de campo, buscamos identificar a materialização dos aspectos anteriormente, visto que "qualquer um que deseje conhecer um fenômeno só poderá ter sucesso se entrar em contato com ele, ou seja, vivê-lo (praticá-lo) dentro do próprio meio deste fenômeno" (Kaiser, 2006 [1949], p. 94). Portanto, obstante ao desejo primeiro de apenas "olhar" um dado objeto em seu estado natural, o pesquisador precisa intentar a interpretação deste evento a partir de um olhar técnico, crítico, perpassando as formas vazias e rasas com que habitualmente olhamos o todo a nossa volta.

Por fim, as observações diretas tiveram o intuito de pontuar o que do rural se perpetua no urbano, tanto dos movimentos de resistências como de permanências das práticas, saberes e vivências, frente ao intenso processo de urbanização e mesmo de metropolização que ocorre de forma diversa e heterogênea, consideradas as diferentes configurações, bem como a situação geográfica de cada uma das cidades elencadas.

\section{IRANDUba E SILVES NO CONTEXTO DA REGIÃO METROPOLITANA DE MANAUS (RMM)}

A região amazônica é caracterizada por dinâmicas sociais, em espaços urbanos e rurais, que se diferenciam em muitos aspectos das demais regiões do país, principalmente pela dinâmica fluvial e a prática de agricultura familiar e ainda que haja absorção das novas tecnologias, como a TV e a internet, há a manutenção de hábitos do cotidiano rural, sendo a ruralidade materializada através de práticas como o cultivo de hortaliças nas varandas e quintais, a criação de pequenos animais nos fundos das casas, a pesca no rio que é a extensão do terreno e mesmo o "falar da vida" com os vizinhos, aspectos incomuns nos grandes centros urbanos, dado o ritmo e intensidade das dinâmicas da cidade, sobretudo nas metrópoles, estendendo-se à metrópole na selva amazonense.

Oliveira (2007) descreve as cidades amazônicas como sendo "lugares onde pulsam modos de vida que se diferem significativamente do padrão caracterizado como urbano em outras regiões do Brasil" (Oliveira, 2007, p. 171, destaque nosso), fato este facilmente observado por quem visita qualquer núcleo urbano na região amazônica.

Desde muito tempo a Amazônia figura como porção do território brasileiro que atrai interesse e desperta cobiça, sendo grande a pressão pela possibilidade de exploração das riquezas da região, seja dos produtos da floresta e do subsolo, seja pelo discurso da grande disponi- 


\section{Geografia, território e sociedade na Amazônia}

bilidade de terras, com potencial para o desenvolvimento de atividades voltadas a agricultura e pecuária, e segundo Bowder e Godfrey (2006) as cidades na Amazônia surgem a partir da implementação de grandes projetos que visavam a ascensão econômica regional bem como a descoberta e exploração de recursos minerais sendo, do ponto de vista das políticas de desenvolvimento regional, ainda hoje, alvo da imposição de modelos que desconsideram as particularidades locais.

Nesta região, observou-se o surgimento de dois grandes centros urbanos que, a partir da implementação de massivos projetos de ocupação, objetivavam manter domínio sob a vastidão territorial (Becker, 2008), tendo, durante o governo militar, expandindo-se e passando a se configurar como metrópoles, ainda que de forma peculiar, sendo a Região Metropolitana de Belém (RMB) e a RMM.

Contudo, a Região Metropolitana de Manaus (RMM), diferentemente das demais regiões metropolitanas do país em que a conurbação é a principal marca, surge predominantemente a partir do interesse estatal em auferir recursos a serem investidos nos municípios integrantes, e para Sousa (2015) a principal iniciativa se materializa através da construção da ponte sobre o Rio Negro, que passou a ligar efetivamente alguns municípios à metrópole amazonense, reduzindo as distancias e impulsionando principalmente o mercado imobiliário, sobretudo nos municípios de Iranduba e Manacapuru.

A RRM consolidou-se a partir de iniciativa estritamente política e engloba atualmente treze municípios do estado do Amazonas, a saber: Autazes, Careiro, Careiro da Várzea, Iranduba, Itacoatiara, Itapiranga, Manacapuru, Manaquiri, Manaus, Novo Airão, Presidente Figueiredo, Rio Preto da Eva e Silves. Contudo, a ausência de características como a conurbação e maior articulação entre os municípios que integram a região metropolitana, a colocam como sendo, nas palavras de Lima (2014), uma metrópole induzida.

Quanto aos aspectos de interação entre os municípios de Iranduba e Silves com a metrópole Manaus, objetos do nosso estudo, pode-se observar uma diferença preponderante, sobretudo no que se refere aos modais de transporte utilizados para o deslocamento entre estes municípios: Iranduba/Manaus, Iranduba/Manaus e Silves/Manaus, Silves/Manaus, também se diferem, havendo maior diversidade e frequência entre os municípios de Iranduba e Manaus, em detrimento do trecho entre as sedes municipais de Silves e Manaus, tanto para o transporte de produtos quanto para o translado de pessoas (tabela 1). 
Ruralidades na Amazônia: materializações
no espaço urbano de Iranduba e Silves [AM]

Tabela 1 - Modais de transporte Iranduba/Manaus

/Iranduba e Silves/Manaus/Silves.

\begin{tabular}{l|l|l}
\hline Modal & Iranduba & Silves \\
\hline Taxi-lotação & $30,00-50,00$ & 100,00 \\
\hline Ônibus (linha) & 5,00 & - \\
\hline Ônibus (interurbano) & - & 74,00 \\
\hline Moto-táxi & $35,00-40,00$ & - \\
\hline Uber/99 & $68,00-75,00$ (até 4 pessoas) & - \\
\hline Embarcação/Recreio & & -
\end{tabular}

Fonte: Coopetaxi Manaus, 2020; ANTT, 2020. Org.: SOUZA, M. P., 2021.

Quando analisado a fluidez de pessoas - sendo observada a migração pendular - e de produtos manufaturados nestes municípios, observa-se que a ponte sobre o Rio Negro facilitou o acesso dos moradores de Iranduba ao município Manaus, a partir da borda Sul da metrópole, conforme observado na Figura 2.

${ }^{1}$ Embarcação que faz o transporte de mercadorias e pessoas na maioria das cidades na Amazônia, sedo em algumas localidades o único meio de chegada e partida. 
Geografia, território e sociedade na Amazônia

Figura 2 - Localização de Iranduba em relação à Manaus/AM.

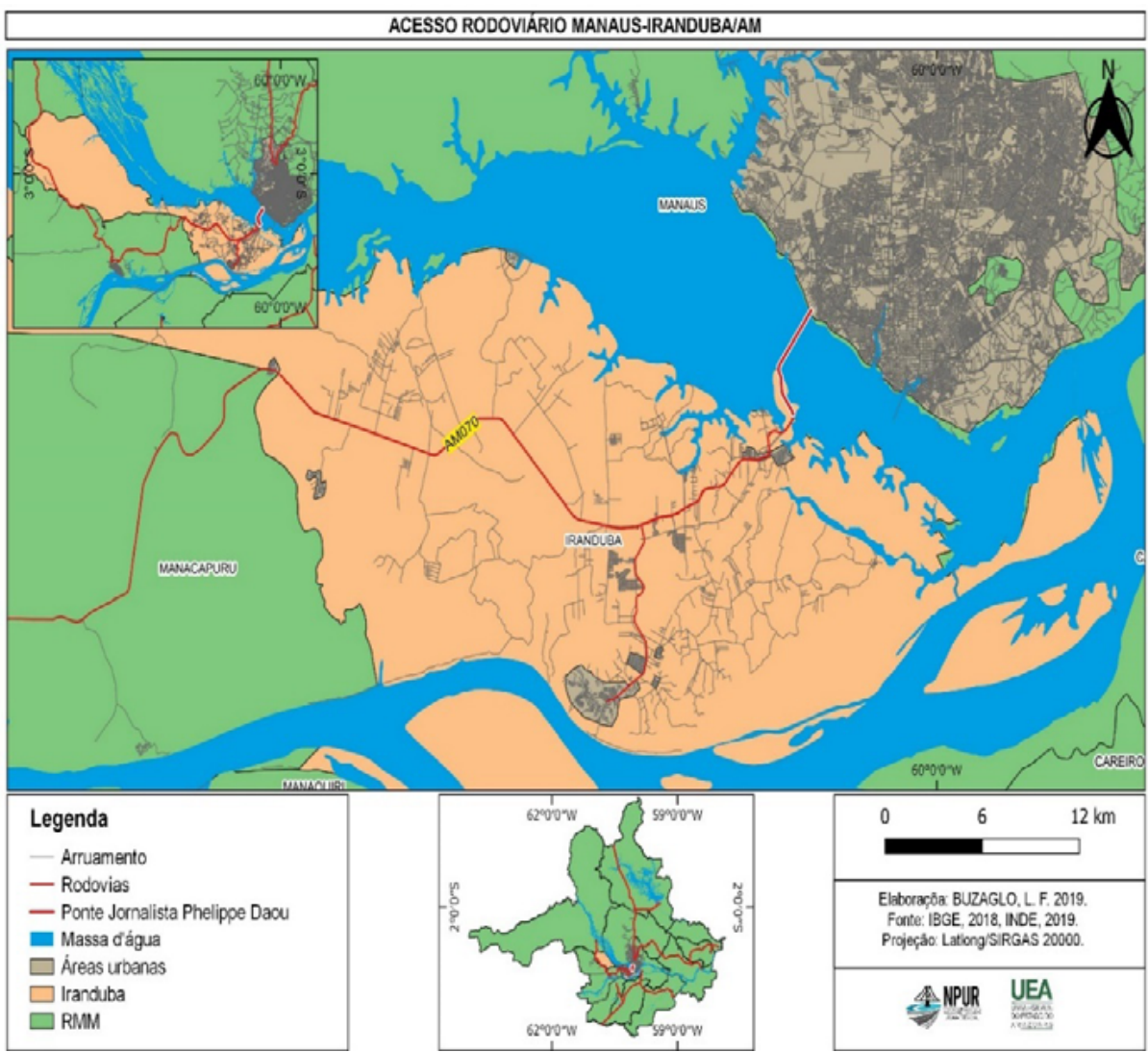

Fonte: IBGE, 2019; INDE, 2019. Org.: Buzaglo, L, F., 2019.

Por outro lado, Silves apresenta menor interação com a metrópole, ainda que tenha ligação continua por terra através da rodovia AM-363 que conecta os municípios de Silves e Itapiranga a capital do Amazonas (Figura 3) e que, após a consolidação da região metropolitana, passou a ser a principal forma de acesso à cidade de Manaus, uma vez que essa "comodidade" fez cair a procura pelos recreios (barcos que fazem o transporte de passageiros na Amazônia) levando ao fim desse modal de transporte entre os municípios. 


\section{Ruralidades na Amazônia: materializações no espaço urbano de Iranduba e Silves [AM]}

Figura 3 - Localização de Silves em relação à Manaus/AM.

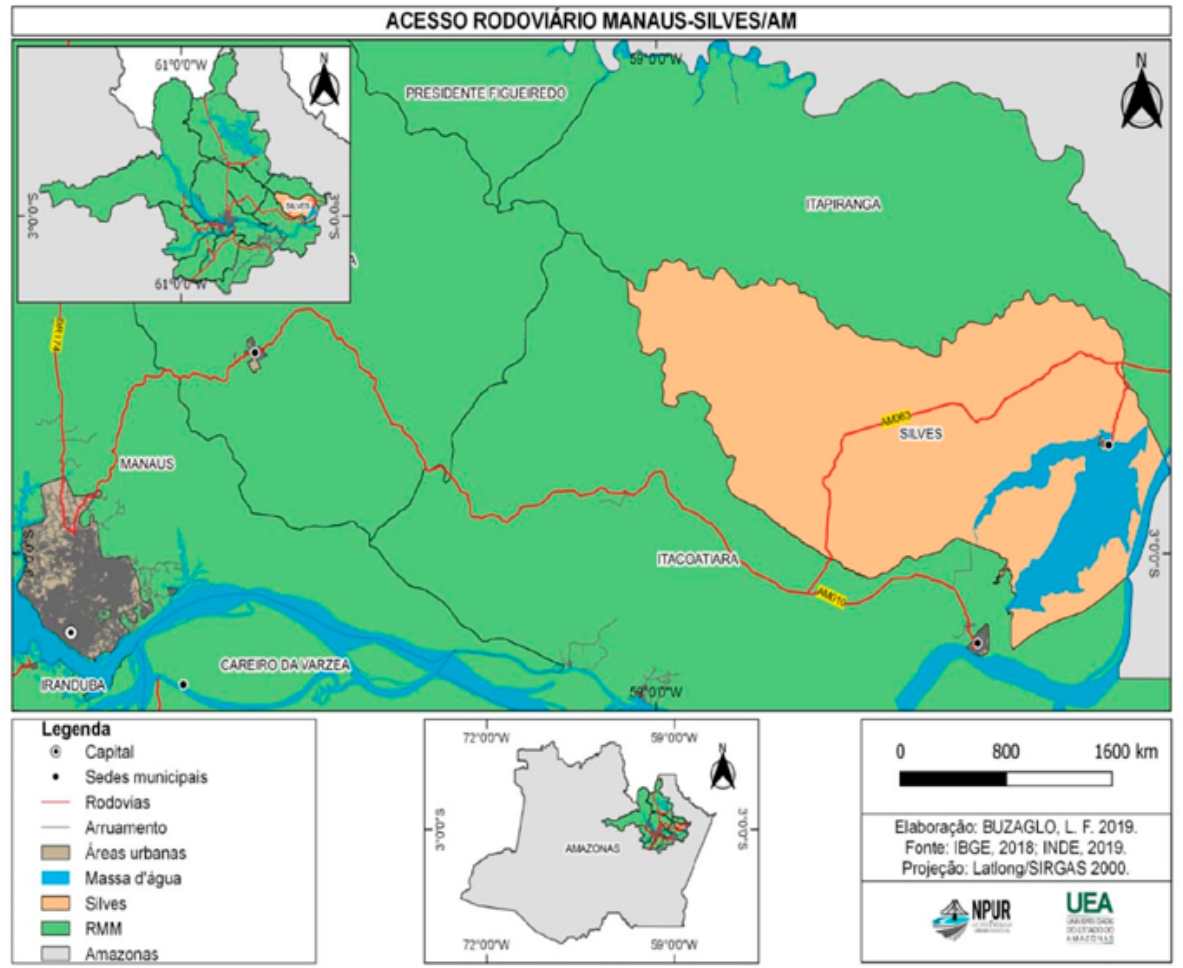

Fonte: IBGE, 2019; INDE, 2019. Org.: Buzaglo, L, F., 2019.

Desta forma, observa-se que quando se trata do deslocamento de pessoas entre os municípios analisados e a metrópole, os modais de transporte priorizados são os que oferecem maior rapidez e frequência - onibus e taxis na modalidade lotação -, e essa redução do tempo de deslocamento intensifica a migração pendular, sobretudo entre Iranduba e Manaus, trajeto facilitado com a ponte, atraindo um maior número de pessoas a procura de melhores oportunidades na capital do Estado.

O processo de metropolização, caracterizado por Sandra Lencioni (2013) como processo de metamorfose do espaço que engendra mudanças significativas na forma, estrutura e natureza do território e que são inerentes a globalização, deve ser considerado como fundamental nesse processo de ressignificação do espaço; tal processo não se restringe a este fenômeno apenas - a globalização -, ocorrendo de modos distintos 


\section{Geografia, território e sociedade na Amazônia}

nos municípios estudados; em Iranduba, os códigos da metrópole encontram-se em maior evidência, pujantes no cotidiano da população que se sente parte da metrópole; já Silves preserva o bucolismo comum às cidades interioranas da Amazônia, entre cochilos à porta das casas, ou nas redes dependuradas nas varandas.

Esse dinamismo observado atualmente requer que avancemos nas análises, e neste sentido Lencioni (2013) argumenta que a interpretação da atual configuração socioespacial nos exige lançar mão de novos conceitos para buscarmos novas classificações que perpassem as antigas formas de apreensão do espaço, e nesse sentido, corroboramos com a autora ao inferirmos que o processo de metropolização se apresenta como perspectiva de análise coerente para a busca da interpretação do espaço contemporâneo pretendida, sendo necessário considera-lo.

Assim, mesmo configurando-se como cidades estruturalmente distintas, Iranduba e Silves têm sua importância junto à metrópole amazonense reconhecidas, uma vez que assumem, dentro do contexto metropolitano, papéis importantes para o desenvolvimento da região; Iranduba, através da oferta de mão de obra, aportando ainda para uma extensão do território de Manaus - de forma simbólica - e Silves, preservando o perfil pacato e de maior contato com a natureza, mantém-se como reserva para futuros espraiamentos, garantindo os espaços necessários à expansão da RMM.

RuRALIDADES DÍSPARES NO URbaNo METROPOLITANO DE IRANDUba E SILVES (AM)

As práticas e vivências de um povo desenvolvidas ao longo do tempo em determinado espaço se tornam sua identidade, sendo este estudo pautado na identificação dos aspectos da ruralidade nas cidades de Iranduba e Silves, das práticas e vivencias comuns ao modo de vida no campo que agora são reproduzidos no espaço urbano dos municípios supracitados e que, por serem estruturalmente distintos, tem sua materialidade também representada de formas distintas.

A ruralidade tem sua materialidade ancorada tanto no plano do visível como de forma subjetiva; portanto, em aspectos que podem ser observados na paisagem, através da ocorrência de formas e estruturas, bem como no desenvolvimento de atividades ligadas a elas, sendo comumente visualizados em comunidades ribeirinhas por toda a Amazônia, 


\section{Ruralidades na Amazônia: materializações no espaço urbano de Iranduba e Silves [AM]}

causando estranhamento aos que porventura nunca tenha se deparado com práticas do cotidiano amazônico.

Além disso, a identificação de aspectos imateriais da ruralidade exige maior crivo por parte do pesquisador dedicado a apreender os contornos da vida rural no contexto amazônico, sendo assim, os estudos que objetivam identificar estas "ilhas de ruralidade" materializadas em espaços tidos como predominantemente urbanos, a nosso ver, devem buscar desvencilhar-se da premissa onde o rural fica totalmente à mercê do urbano. Portanto, estas práticas rurais que se perpetuam na cidade, se desprendem da realidade urbana (Lefebvre, 2001).

Esses processos de apropriação do território carregam em si, além dos costumes já mencionados, valores e representações construídas ao longo de toda uma vida, tornando-se evidência de que apesar das mudanças assistidas, aqui caracterizadas como movimentos de desterritorialização e reterritorialização, os sujeitos continuam a reproduzir seus hábitos e costumes tradicionalmente constituídos e pertencentes à memória coletiva, observadas em Iranduba e Silves através da ocorrência de formas e tipologias do rural no espaço urbano dessas cidades.

Nesse sentido, uma primeira distinção entre as cidades analisadas encontra-se na disposição em que o fenômeno - a ruralidade - pode ser observado. Iranduba apresenta, na região central da cidade, a maior parte das ocorrências, conforme a Figura 4, constatando que esta zona foi a pouco tempo pertencente a zona rural do município e que, incorporada ao perímetro urbano, passou a ter diferentes usos, sendo parcelado em lotes menores para serem vendidos a terceiros, processo muito observado a partir da expansão de áreas urbanas. 
Geografia, território e sociedade na Amazônia

Figura 4 - Ruralidades no urbano de Iranduba.

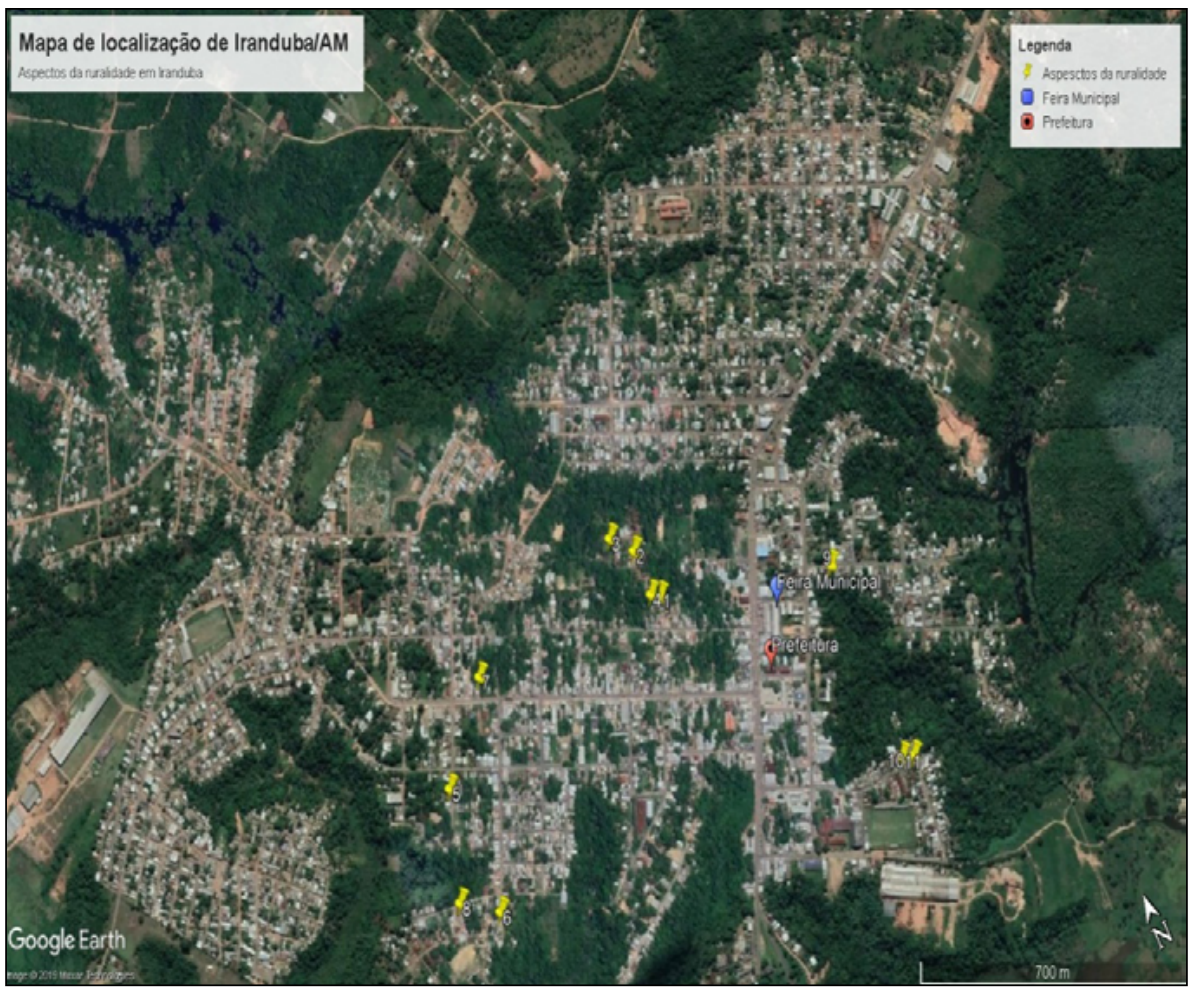

Fonte: Google Earth, 2019; trabalho de campo, 2019. Org.: SOUZA, M. P., 2020.

Destacamos onze pontos dentro da área urbana do município que a nosso ver representam o resistir de costumes e práticas dos rurais dentro de um espaço que impõe o urbano como modo de viver e habitar, exprimindo de diversas formas a difusão de códigos metropolitanos.

Por sua vez, Silves apresenta uma distribuição espacial muito maior destes pontos, constando registros em praticamente todas as zonas do município, como podemos constatar no Figura 5. Chama atenção o fato de que toda ilha - parte do município - constar como pertencente a zona urbana, conforme o Código de Postura do Município de Silves - CPMS (Amazonas, 2014). Além disso, a ruralidade nesse município apresenta-se como permanência de um modo de vida e práticas comuns 


\section{Ruralidades na Amazônia: materializações no espaço urbano de Iranduba e Silves [AM]}

ao cotidiano dos moradores, que não se perdeu, mesmo com as investidas do modo de vida urbano.

Figura 5 - Ruralidades no urbano de Silves.

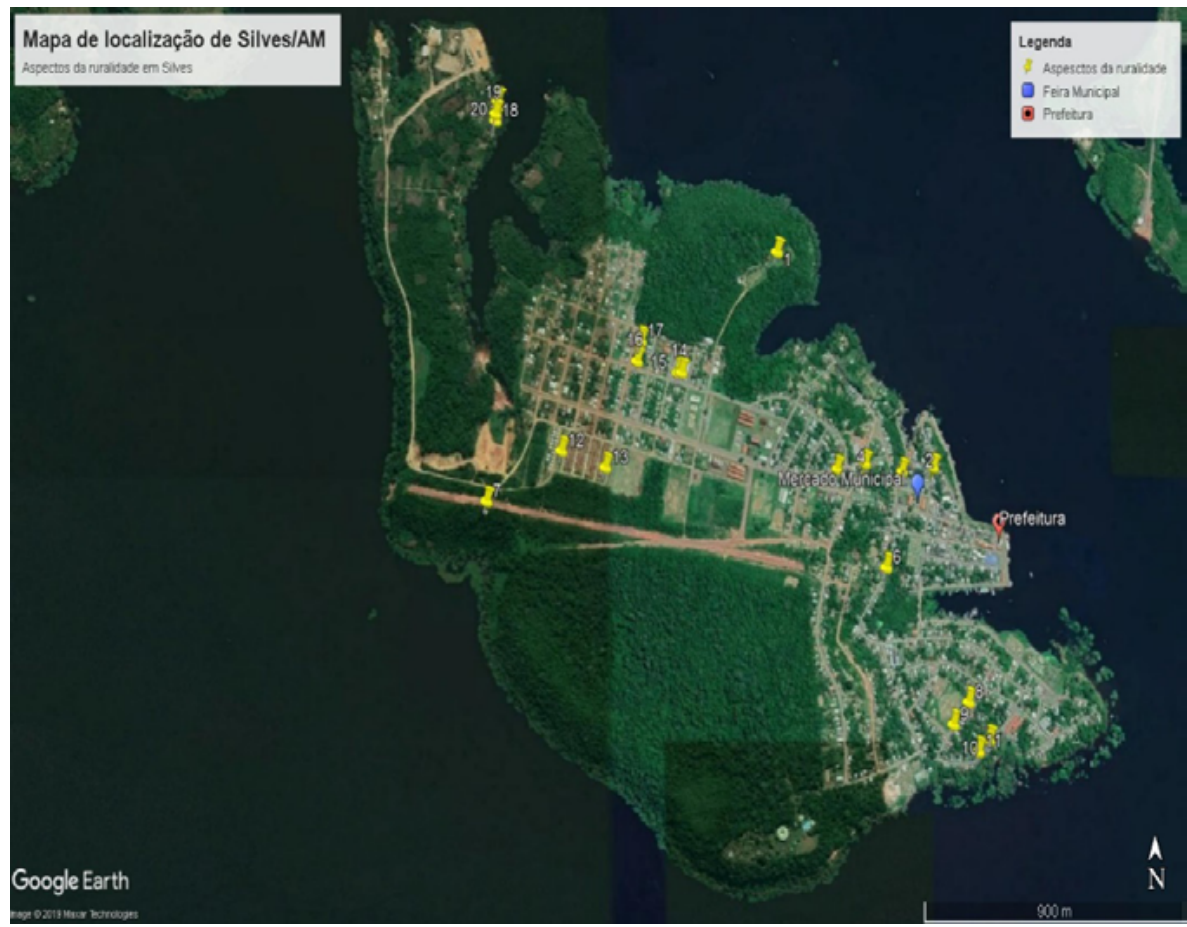

Fonte: Google Earth, 2020. Org.: SOUZA, M. P., 2020.

Observa-se de forma marcante por toda a extensão da ilha a tipologia das casas e como estas estruturas remetem a vida rural, considerando ainda as particularidades da região amazônica. Segundo Castro (2011) as moradias em áreas rurais da Amazônia são caracterizadas por conter terras em abundância, sendo essa extensão ao redor da casa utilizada para o cultivo de produtos voltados à alimentação e complemento de renda às famílias. Portanto, os quintais configuram-se como a:

área ao redor da casa do produtor, onde são cultivadas árvores frutíferas, grãos, hortaliças, plantas medicinais e ornamentais e criação de animais, tem como finalidade principal a comple- 
mentação da produção obtida em outras áreas de produção da propriedade, como a roça, a criação de animais, a floresta e as capoeiras melhoradas (Castro, et al., 2011, p. 60).

Em Iranduba foi possível identificar a criação de animais nos quintais das residências - galinhas, patos, jabutis -, voltada essencialmente para o consumo familiar, troca ou partilha com os vizinhos, prática que se mostrou comum entre os residentes deste espaço, sendo comercializados apenas o excedente da produção, como forma de complemento à renda das famílias.

Prática semelhante também foi identificada em Silves, a criação de animais no espaço excedente (Figura 6). No entanto, nessa localidade, a ocorrência desse tipo de atividade foi consideravelmente maior quando comparada a Iranduba. Dentre os fatores que contribuem para o grande número de famílias que se dedicam a estas práticas pode-se elencar a baixa oferta e o valor elevado da carne bovina, que chega ao município uma vez a cada semana. 
Ruralidades na Amazônia: materializações

no espaço urbano de Iranduba e Silves [AM]

Figura 6 - Criação de animais em quintais de Iranduba e Silves.
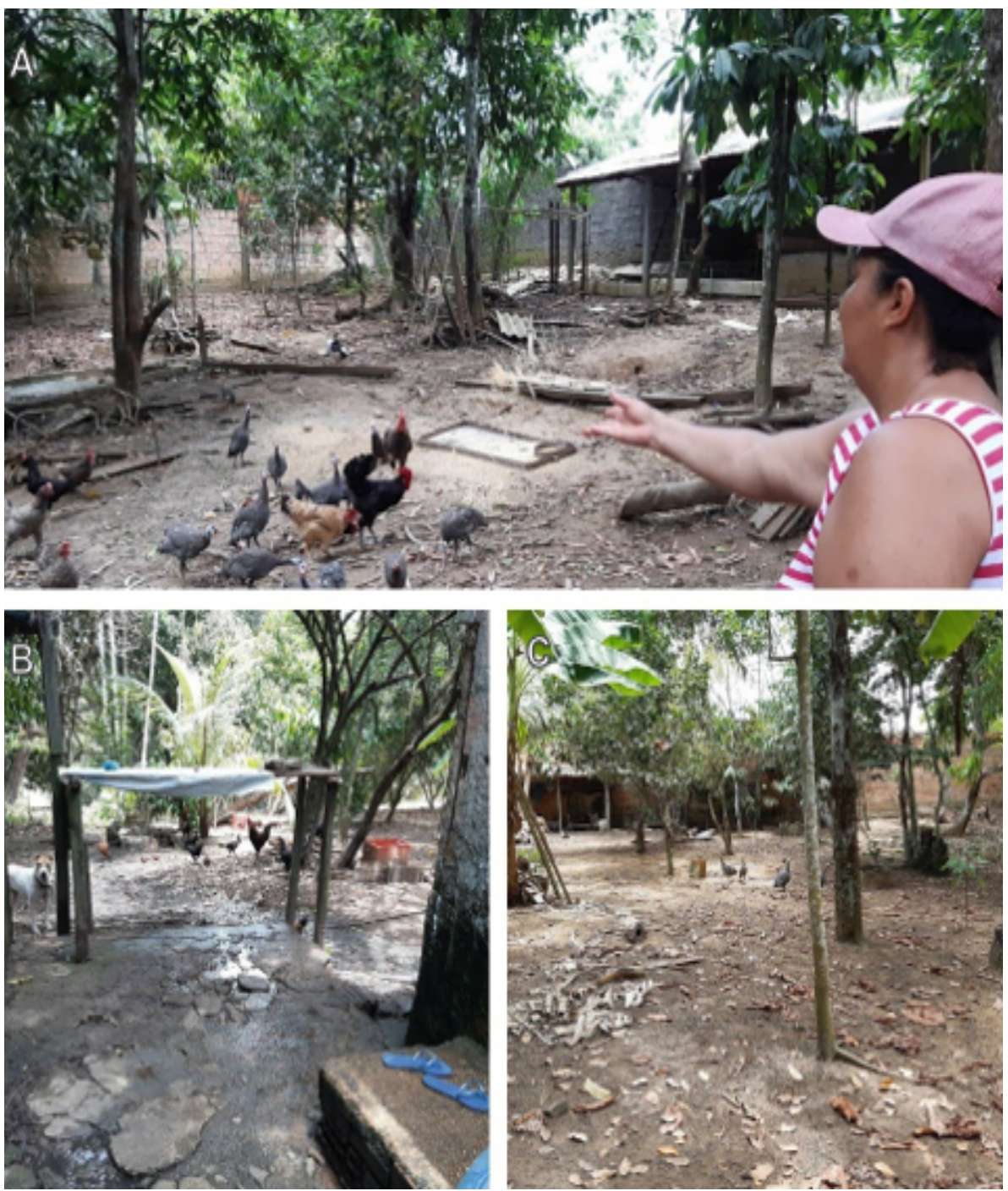

Legenda: a) criação de animais em Iranduba; b) e c) criação de animais em Silves.

Fonte: SOUZA, M. P., 2019. 
Na Amazônia, a vida no campo se perpetua como forma de representação cultural, um modo de vida que se difere do cotidiano da cidade; desse contato - entre campo e cidade - emergem novas formas de construção identitária dos sujeitos, induzindo a uma supressão da vida cotidiana passada que sofre a resistência por parte de quem, ainda assim, busca vivenciar o campo que agora é cidade, podendo ser observado através de geossímbolos presentes na paisagem urbana (Floriani, 2017).

Ainda que a realidade rural/urbana dos municípios do Amazonas tenha sido alterada ao longo dos anos, em Iranduba e Silves adentra às casas uma realidade diferente, desde os objetos e o mobiliário em madeira e mesmo os canteiros suspensos, outra materialidade dos costumes do campo, estruturas que recebem a plantação de hortaliças em locais mais altos a salvos dos animais como galinhas e porcos, e são construídos nos quintais e nas varandas (Figura 7), onde são cultivados Hortaliças como a cebolinha (Alliun schoenoprasum L.; Alliun fistulosum L.), o coentro (Coriandrum sativum L.), a chicória (Cichorium endivia L; Eryngium foetidum L.) e que fazem parte da cultura alimentar da população amazônica, lugares onde todos se conhecem e são ocupados por famílias que tradicionalmente se estabeleceram ali há muitos anos. 


\section{Ruralidades na Amazônia: materializações no espaço urbano de Iranduba e Silves [AM]}

Figura 7 - Quintais residenciais em Iranduba e Silves.
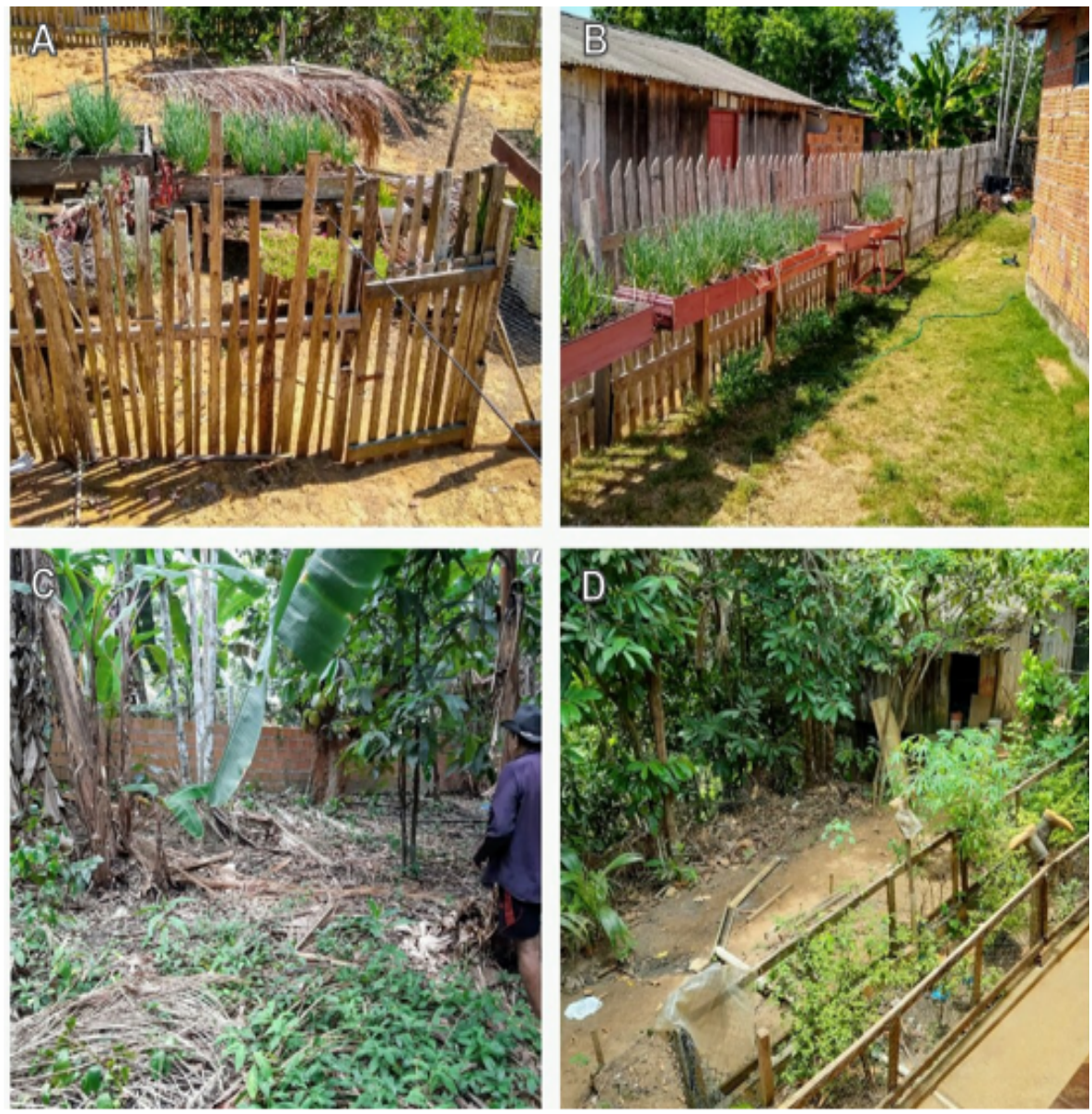

Legenda: a; b) canteiros suspensos em Silves; c; d) plantio de banana e hortaliças nos quintais em Iranduba. Fonte: SOUZA, M. P., 2019.

$\mathrm{Na}$ região amazônica, as várzeas, terras inundáveis periodicamente (Pereira, 2011), são utilizadas no tempo da seca dos rios para o cultivo em larga escala, principalmente da mandioca e da macaxeira, produtos muito apreciados pela população local, sendo comumente encontrados em feiras e mercados locais. Ainda assim, os irandubenses ${ }^{2}$

${ }^{2}$ Gentílico da população natural de Iranduba. 
e silvenses ${ }^{3}$ dedicam parte do seu tempo e alguma porção de seus quintais ou mesmo áreas públicas para o cultivo desses tubérculos, acompanhado de outras culturas, como o abacaxi, a cana de açúcar e a banana (Figura 8).

Figura 8 - Cultivo de tubérculos e frutas em quintais - Iranduba e Silves (AM).
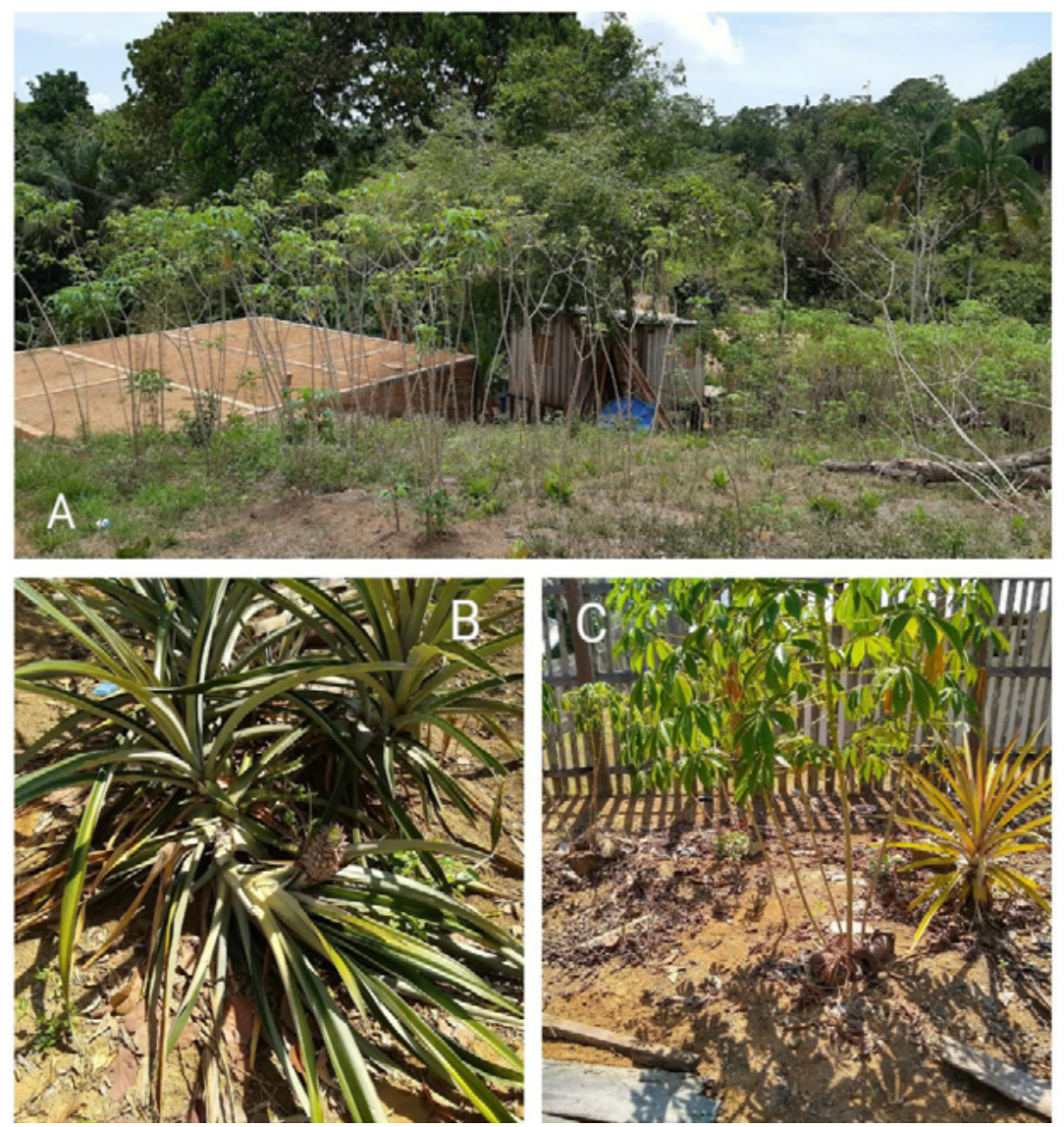

Legenda: a) cultivo de mandioca - Iranduba; b) cultivo de abacaxi e c) cultivo de macaxeira - Silves.

Fonte: SOUZA, M. P., 2019.

${ }_{3}^{3}$ Gentílico da população natural de Silves. 


\section{Ruralidades na Amazônia: materializações no espaço urbano de Iranduba e Silves [AM]}

Essas atividades, apesar de trabalhosas, não têm como finalidade principal o comércio e sim o consumo familiar, além de podermos observar a ocorrência de escambo (troca de produtos) entre parentes e vizinhos mais próximos. Assim, as terras onde são desenvolvidas essas atividades se tornam espaços onde se materializam os processos de reterritorialização onde, tendo início o processo de tomada pelo urbano, os agentes sociais engendram novas dinâmicas, impondo costumes e práticas não observadas anteriormente e que agora são vistas com estranheza; o homem do campo, agora citadino, resiste a essas imposições, agarrando-se ao campo através de ressignificações em suas práticas socioterritoriais.

Além disso, o "ser da roça" permeia a vida dessa parcela dos moradores, sobretudo nos fragmentos onde o Estado altera o status legal da terra, incluindo estes espaços à zona urbana dos municípios, desconsiderando as estruturas materiais e imateriais historicamente estabelecidas, sendo mantida a infraestrutura precária comum ao campo; não há asfalto, não há calçamento adequado, não há rede de drenagem, há, porém, o Imposto sobre Propriedade Predial e Territorial Urbana $(\text { IPTU })^{4}$, fato observado em ambas as cidades (Figura 9). 
Geografia, território e sociedade na Amazônia

Figura 9 - Bairro Alto, região central de Iranduba.

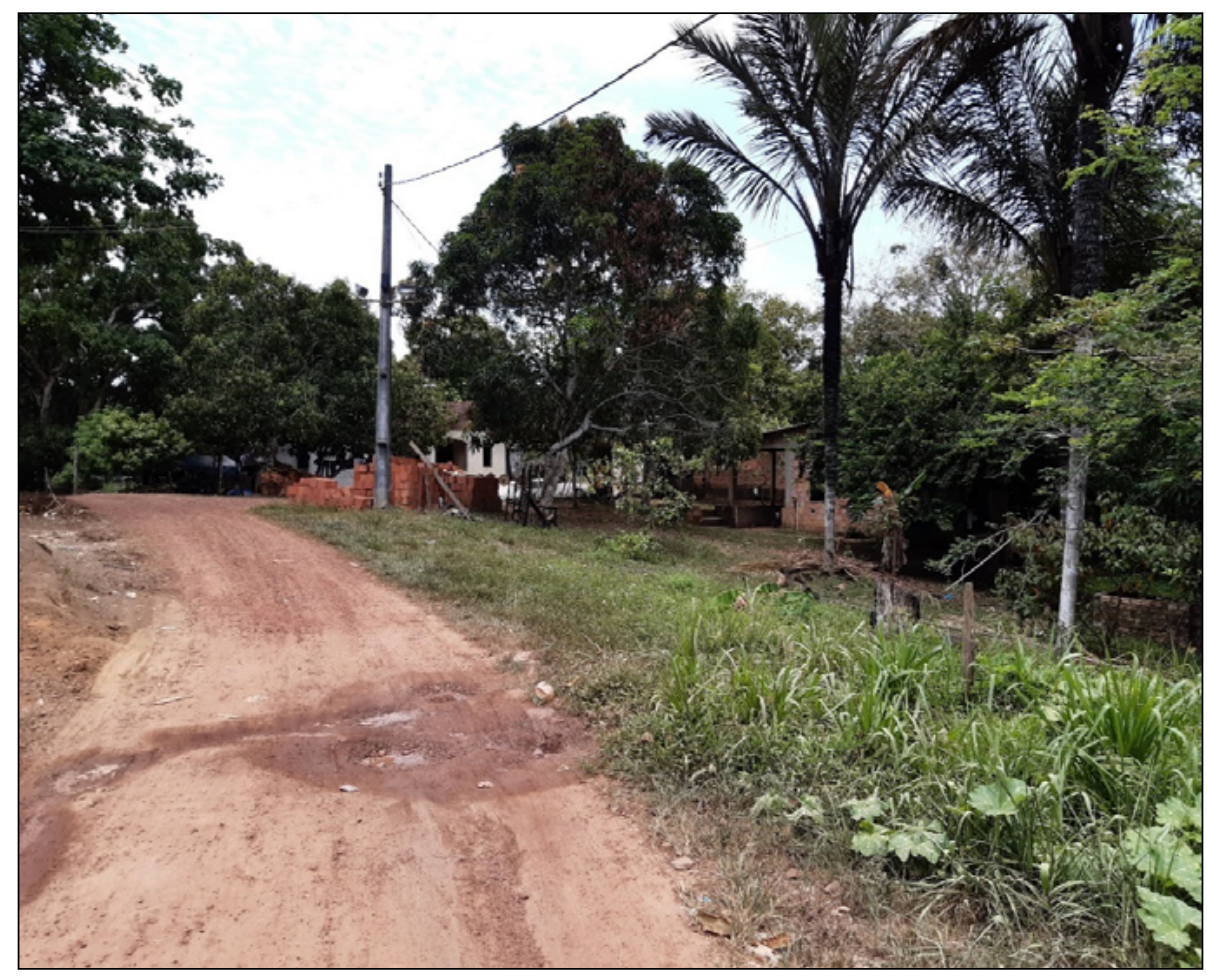

Fonte: Souza, M. P., 2019.

Nesses espaços, torna-se nítida a importância que a vida campesina assume para os indivíduos, sendo imediatamente associada a tranquilidade, ao silêncio e mesmo ao frescor da sombra das arvores, mantendo ainda antigas configurações das propriedades, mesmo agora, inseridas no espaço urbano (Figura 10). 


\section{Ruralidades na Amazônia: materializações no espaço urbano de Iranduba e Silves [AM]}

Figura 10 - Residência na zona urbana de Iranduba.

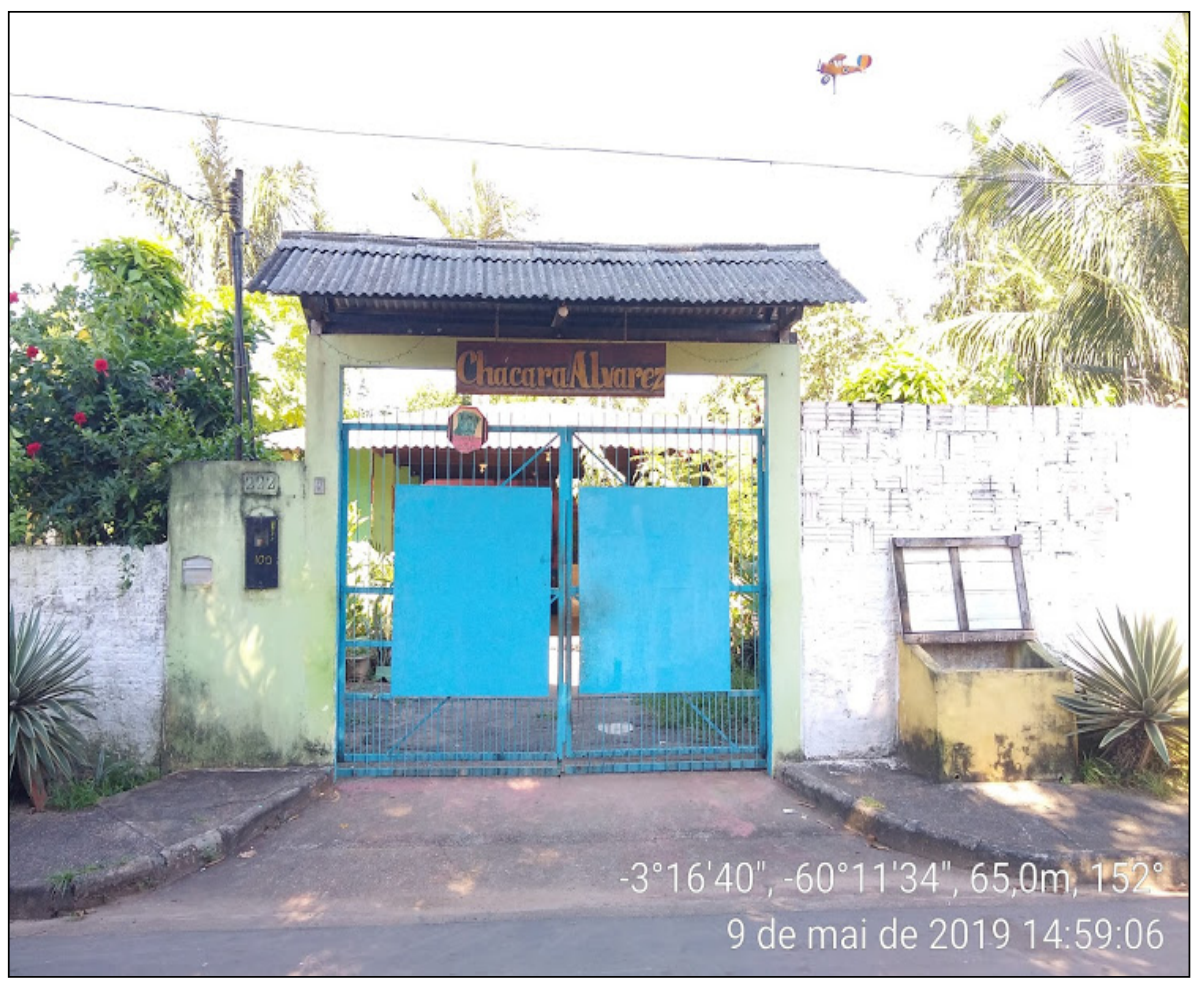

Fonte: Souza, M. P., 2019.

Essas rugosidades - chácaras e casas em madeira com quintais amplos e abertos, construídas em um tempo pretérito e que assumem novas funções - são comumente observadas no espaço urbano destes municípios, assim como a diversidade de arvores frutíferas e as práticas de cultivo de hortaliças, que se tornam a representação do rural no urbano, a materialização da ruralidade, evidenciando o porquê da luta destes atores sociais em manterem suas relações com suas raízes caboclas, presentes, sobretudo, no cotidiano.

É possível notar que as influências sofridas em decorrência da vida e da difusão dos códigos urbanos e metropolitanos, em conjunto com as práticas observadas, formam uma linha tênue que configura o modo de vida rurbano, sendo esta uma condicionante das novas espacialidades expressas não somente na paisagem como também no dia a dia em Iranduba e Silves. 


\section{Geografia, território e sociedade na Amazônia}

\section{CONSIDERAÇÕES FINAIS}

Em seu conjunto, estes aspectos - casa, cultivo de hortaliças, criação de animais para consumo - constituem os geossímbolos deste rural no qual são se entrelaçam as teias sociais que se estabelecem, tornando a ruralidade algo que se expressa de forma natural no cotidiano, como formas de permanências culturais e simbólicas.

De fato a modernidade chega, de uma forma ou de outra, contudo, ainda que muitos dos atores sociais aqui representados tenham absorvido estas novas "imposições" do modo de vida urbano, há uma nítida transformação nos hábitos e costumes sem que se perca a essência campesina, por nós compreendida como resultantes dos processos de reterritorialização, recriando e ressignificando antigas práticas como forma de manutenção da ligação com o passado - a vida rural - dando rigidez aos geossímbolos que remetem ao espaço rural e que contrastam com a paisagem urbana nas cidades estudadas, resultando na perceptível hibridez observada no espaço de Iranduba e Silves.

Esse rural no urbano amazônico tem suas unicidades; diferencia-se, portanto, em muitos aspectos do rural que se vê no jornal ou na TV. No Amazonas, até a farinha tem casa, e nesses lugares a vida rural se vive, devagar; pelo rio, se vem, se vai, e dele, se mata a sede, a fome, em parte, ele comanda o ritmo da vida na região.

Por outro lado, na cidade grande tudo corre em disparada e a vida urbana passa, longas distâncias, tempos curtos, e assim, o "progresso enganador", como quem arranca a mandioca do chão, desprende as raízes do caboclo, deixando no lugar um espaço vazio que busca preencher-se, ser e estar neste novo lugar, o urbano.

Acreditamos que, ainda que distintos, os espaços urbano e rural são complementares entre si, um não exclui ao outro. Contudo, a coexistência de forma harmônica exige que sejam observadas suas particularidades, sobretudo quando da elaboração dos planos diretores municipais, bem como de projetos voltados à manutenção das práticas culturais dessa população rural que é trazida para a cidade. Faz-se necessário, portanto, dar voz a estes agentes sociais, incluindo-os no processo decisório e de elaboração destes dispositivos, uma vez que esses são os mais afetados a partir das mudanças que tem se estabelecido 


\section{Ruralidades na Amazônia: materializações \\ no espaço urbano de Iranduba e Silves [AM]}

\section{REFERÊNCIAS}

AMAZONAS. Lei Complementar n. 005 de 9 de janeiro de 2014. Altera a redação da Lei 113/1994 que institui o código de posturas do município de Silves e dá outras providências. Diário Oficial dos Municípios do Amazonas, Amazonas, 10 jan. 2014. Disponível em: www.diariomunicipal.com.br/aam/. Acesso em: $1^{\circ}$ ago. 2020.

AMAZONAS. Lei n. 129, de 21 de fevereiro de 2011. Institui o Plano Diretor do município de Iranduba e dá outras providências. Diário Oficial do Estado do Amazonas, Amazonas, 22 fev. 2011. Ano II, n.0287. Disponível em: www.diariomunicipal.com.br/aam. Acesso em: $1^{\circ}$ ago. 2020.

ALVES, F. D. Considerações sobre métodos e técnicas em Geografia humana. Dialogus, Ribeirão Preto, v. 4, n. 1, 2008, p. 227-241.

BECKER, B. K. Um futuro para a Amazônia. São Paulo: Oficina de Textos, 2008.

BOWDER, J. O. GODFREY, B. J. Cidades na floresta: urbanização, desenvolvimento e globalização na Amazônia brasileira. Trad. Gisele Vieira Goldstein. Manaus: Editora da UFAM, 2006.

CASTRO, A. P. et al. A agricultura familiar: principal fonte de desenvolvimento socioeconômico e cultural das comunidades da área focal do Projeto PIATAM, In: FRAXE, T. J. P. PEREIRA, H. S. WITKOSKI, A. C. (org.). Comunidades ribeirinhas amazônicas: modos de vida e uso dos recursos naturais. Manaus: Reggo Edições, 2011, p. 55-90.

CORRÊA, R. L. O espaço urbano. São Paulo: Editora Ática, 1989.

FLORIANI, N. et al. Microterritorialidades rurais em um espaço urbano no sul do Brasil: imaginários geográficos e outros modos de habitar a cidade. In: LIMA, M. SHIRAISHI NETO, J. SOUZA FILHO, B. (org.). Dinâmicas territoriais e conflitos socioambientais. São Luís: EDUEMA, 2017.

HAESBAERT, Rogério. O mito da desterritorialização: do "fim dos territórios” à multiterritorialidade. Rio de Janeiro: Bertrand Brasil, 2004.

KAISER, B. O geógrafo e a pesquisa de campo. Boletim Paulista de Geografia, São Paulo, n. 84, p. 93-104, 2006.

LEFEBVRE, H. O direito à cidade. São Paulo: Centauro, 2001.

LENCIONI, S. Metropolização do espaço: processos e dinâmicas. In. FERREIRA, A. et al. (org.). Metropolização do espaço: gestão territorial e relações urbano-rurais. Rio de Janeiro: Consequência, 2013. 
LIMA, M. C. Quando o amanhã vem ontem: a institucionalização da região metropolitana de Manaus e a indução ao processo de metropolização do espaço na Amazônia ocidental. Tese (Doutorado em Geografia Humana) - Faculdade de Filosofia, Letras e Ciências Humanas, Universidade de São Paulo, São Paulo, 2014. DOI: 10.11606/T.8.2014. tde-06042015-191044. Acesso em: 14 set. 2019.

MARCONI, M. A. LAKATOS, E. M. Metodologia do trabalho científico: procedimentos básicos, pesquisa bibliográfica, projeto e relatório, publicações e trabalhos científicos. 7. ed. 2. reimpr. São Paulo: Atlas, 2008.

MORESI, E. (Org.). Metodologia científica. Brasília-DF: Universidade Católica de Brasília, 2003.

OLIVEIRA, J. A. Cidades rios e floresta: raízes fincadas na cultura na terra e na natureza. In: BRAGA, S. I. G. (org). Cultura popular, patrimônio imaterial e cidades. Manaus: Editora da Universidade Federal do Amazonas, 2007.

PEREIRA, H. S. Dinâmica da paisagem socioambiental das várzeas do Rio Solimões-Amazonas. In: FRAXE, T. J. P. PEREIRA, H. S. WITKOSKI, A. C. (Org.). Comunidades ribeirinhas amazônicas: modos de vida e uso dos recursos naturais. Manaus: Reggo Edições, 2011, p. 11-32.

RUA, J. Urbanidades no rural: o devir de novas territorialidades. Campoterritório: Revista de Geografia Agrária, v. 1, n. 1, 2006.

FERREIRA, A. et al. Urbanidade, urbanidades, urbanidades no rural: uma construção para melhor compreender a unicidade do espaço geográfico. (org.). Metropolização do espaço: gestão territorial e relações urbano-rurais. Rio de Janeiro: Consequência, 2013.

SANTOS, M. A natureza do espaço. São Paulo: Edusp, 2006.

SANTOS, M. A urbanização brasileira. 5. ed. 3. reimp. São Paulo: Edusp, 2013.

SOUSA, I. S. A ponte Rio Negro e a reestruturação do espaço na região metropolitana de Manaus: um olhar a partir de Iranduba e Manacapuru. Manaus: Editora REGGO/UEA Edições, 2015.

SPOSITO, E. S. A questão do método e a crítica do pensamento geográfico. In: CASTRO, I. E. MIRANDA, M. EGLER, C. (org.). Redescobrindo o Brasil 500 anos depois. Rio de Janeiro: Bertrand: Faperj, 2000. p. 247-359.

SPOSITO, E. S. Geografia e filosofia: contribuição para o ensino do pensamento geográfico. São Paulo: Editora UNESP, 2004. 


\section{SÚMULA CURRICULAR}

\section{Alyson Fernando Alves Ribeiro}

Estudante de Pós-Doutorado na Faculdade de Filosofia, Letras e Ciências Humanas da Universidade de São Paulo (FFLCH - USP), bolsista CNPq. Doutor pelo Programa de Pós-Graduação em Geografia da Universidade Federal de Sergipe (PPGEOIUFS), com Estágio doutoral na Universidad de Alicante (Espanha). Mestre em Geografia pela Universidade Federal de Rondônia (PPGG-UNIR). Licenciado em Geografia pela Universidade Federal de Sergipe (UFS). Pesquisador no Laboratório de Estudos Territoriais (LATER/PPGEO/UFS) e dos grupos de pesquisas; Gestão do Território e Geografia Agrária da Amazônia GTGA (UNIR) e Grupo Interdisciplinario de Estudios Crítico y de América Latina (GIECRYAL/ Universidad Alicante). E-mail: alyson_pop17@hotmail.com

\section{EDNILSON GoMES DA SILVA}

Técnico em Assuntos Educacionais do Instituto Federal do Acre (IFAC). Graduado em Geografia pela Universidade Federal de Acre (UFAC), Mestre em Geografia pelo Programa de Pós-Graduação em Geografia da Fundação Universidade Federal de Rondônia (PPGG/UNIR). Pesquisador do Laboratório de Gestão de Território (Laget/UNIR). E-mail: ednilson. silva@ifac.edu.br

\section{Elisane Pereira da Silva}

Professora de Geografia da Rede Municipal de Ensino de Oriximiná (SEMED/Oriximiná). Mestra em Geografia pelo Programa de PósGraduação em Geografia da Universidade Federal de Rondônia (PPGG/ UNIR). Licenciada e Bacharela em Geografia pela Universidade Federal do Pará (UFOPA). Participa do Grupo de Pesquisa em Gestão do 
Território e Geografia Agrária da Amazônia (GTGA/UNIR). E-mail: zanepesil@gmail.com

Erlainy Joanna Souza de Paiva

Graduada em Geografia pela Universidade do Estado do Amazonas (UEA). Pesquisadora do Núcleo de Estudos Socioambientais da Amazônia (NESAM/UEA, Tabatinga). Mestra em Geografia pela Programa de PósGraduação em Geografia da Universidade Federal de Rondônia (PPGG/ UNIR). Participa do Laboratório de Gestão do Território (Laget/UNIR). E-mail: erlainypaiva@gmail.com

\section{Eubia ANDrÉa Rodrigues}

Professora de Geografia do Centro de Estudos Superiores de Tefé (CEST) da Universidade do Estado do Amazonas (UEA). Doutoranda em Geografia (PPGG/UNIR), graduada em Geografia (UFJF). Membro do Laboratório de Gestão do Território (Laget/UNIR), Pesquisadora do Grupo de Pesquisa em Gestão do Território e Geografia Agrária da Amazônia (GTGA/UNIR), do Núcleo de Pesquisas das Cidades da Amazônia Brasileira (NEPECAB/UFAM) e do Educação em Contextos Amazônicos (EDUCA/UEA). E-mail: eandrea@uea.edu.br

\section{Francilene Sales da Conceição}

Professora do Curso de Geografia da Escola Normal Superior (ENS) da Universidade do Estado do Amazonas (UEA). Doutoranda em Geografia e Mestra em Geografia (PPGG/UNIR), graduada em Geografia (UFPA). Membro do Laboratório Gestão do Território (Laget/UNIR), pesquisadora do Grupo de Pesquisa Gestão do Território e Geografia Agrária da Amazônia (GTGA/UNIR) e do Núcleo de Pesquisas Urbanas e Regional (NPUR/UEA). E-mail: fconceicao@uea.edu.br

\section{Luís Augusto Pereira Lima}

Professor de Geografia da Rede Pública de Ensino do Estado de Amazonas (SEDUC/AM) e Prefeitura Municipal de Manaus (SEMED/Manaus). Graduado em Geografia (UEA), Mestre em Cartografia Social e Política da Amazônia (UEMA), Doutor em Geografia pela Universidade Federal de Rondônia (PPGG/UNIR). Membro do Grupo de Pesquisa em Gestão 


\section{Súmula Curricular}

do Território e Geografia Agrária da Amazônia (GTGA/UNIR) e do Projeto Nova Cartografia Social da Amazônia (PNCSA-UEA/UFAM). E-mail: aplluisster@gmail.com

\section{Matheus Pinto de Souza}

Graduado em Geogdrafia pela Universidade do Estado do Amazonas (UEA). Bolsista CAPES. Mestrando do Programa de Pós-graduação em Geografia da Universidade Federal de Rondônia (PPGG/UNIR). Membro do Grupo de Pesquisa em Gestão do Território e Geografia Agrária na Amazônia (GTGA/UNIR). Tem experiência na área de Geografia Humana, com ênfase em Teoria da Geografia, Geografia Urbana e Política, processo de metropolização, territorialidades e produção do espaço.E-mail: mpds.geo15@uea.edu.br

\section{Neli Aparecida de Mello-Théry (In memoriam)}

Professora Titular na Escola de Artes, Ciências e Humanidades (EACH) da Universidade de São Paulo (USP). Doutora em Geografia Humana pela USP. Foi professora visitante nas Université de Paris X, Nanterre (2000), Université de Rennes 2 (2005 e 2008) e na Université Paris Sorbonne-Nouvelle (2008). Sua experiência abrange, principalmente, os seguintes temas: Amazônia, gestão ambiental, dinâmicas territoriais, políticas ambientais e territoriais, meio ambiente e desenvolvimento sustentável. Autora dos livros Território e Gestão Ambiental na Amazônia: Terras públicas e os dilemas do Estado (2011), Políticas Territoriais na Amazônia (2006) e coautora do Atlas do Brasil - Disparidades e Dinâmicas do Território $(2005,2008,2018)$, entre outros.

\section{Ricardo Gilson da Costa Silva}

Professor do Departamento de Geografia, Coordenador do Programa de Pós-Graduação em Geografia (PPGG) e docente do Programa de Pósgraduação Mestrado Profissional Interdisciplinar em Direitos Humanos e Desenvolvimento da Justiça (DHJUS) da Universidade Federal de Rondônia (UNIR). Doutor em Geografia Humana pela Universidade de São Paulo (USP), e Posdoctorado en Ciencias Humanas y Sociales en la Facultad de Filosofía y Letras de la Universidad de Buenos Aires (UBA). Coordenador do Laboratório de Gestão do Território (Laget) e 
do Grupo de Pesquisa em Gestão do Território e Geografia Agrária da Amazônia (GTGA/CNPq).E-mail: rgilson@unir.br

\section{Silvia Da Silva Correa}

Professora de Geografia da Rede Municipal de Ensino de Oriximiná (SEMED/Oriximiná). Mestra em Geografia pelo Programa de PósGraduação em Geografia da Universidade Federal de Rondônia (PPGG/ UNIR). Licenciada e Bacharela em Geografia pela Universidade Federal do Pará (UFOPA). Tem experiência na área de Geografia, atuando principalmente nos seguintes temas: território, transformações socioespaciais e geografia agrária. E-mail: silvia.silvacorrea@gmail.com

\section{Silvio Simione DA Silva}

Professor da Universidade Federal do Acre (UFAC). Doutor em Geografia pelo Programa de Pós-graduação em Geografia da Universidade Estadual Paulista (UNESP/FCT). Pós-Doutorado pelo Programa de Pós-graduação em Geografia da Universidade Federal de Goiás (UFG). Atua nos Cursos de graduação em Geografia e Mestrado de Geografia da UFAC. Área de Pesquisa: Geografia Agrária, Amazônia, Acre, Produção Camponesa. E-mail: ssimione@gmail.com

\section{Hervé Théry}

Doutor em Geografia pela Université Paris 1 (Panthéon-Sorbonne), Habilitation à diriger des recherches (Livre docência) pela Université Paris X Nanterre (1994). Atualmente é pesquisador emérito do Centre National de la Recherche Scientifique (CNRS), professor visitante da USP (Programa de pós-graduação em Geografia Humana, PPGH). Coordenador editorial da revista Confins (https://journals.openedition. org/confins/). Tem experiência na área de Geografia, com ênfase em Geografia Regional, atuando principalmente nos seguintes temas: geografia do Brasil, geografia política, cartografia temática, modelização gráfica. E-mail: herve.thery@usp.br 


\section{Súmula Curricular}

\section{Viviane Vidal da Silva}

Professora da Universidade Federal do Amazonas, no Instituto de Educação, Agricultura e Ambiente e do Programa de Pós-Graduação em Ciências Ambientais/ IEAA-UFAM. Doutora em Ecologia Aplicada pela ESALQ/USP, Licenciatura em Geografia pelo Claretiano Centro Universitário. Atualmente é doutoranda no Programa de Pós-Graduação em Geografia da Universidade Federal de Rondônia (PPGG/UNIR). Desenvolve pesquisa nos temas: Uso da terra, gestão e dinâmicas territorial e ambiental na Amazônia. É líder do grupo de pesquisa Política, Cultura e Meio Ambiente no contexto amazônico (CNPQ) e pesquisadora do Grupo de pesquisa Gestão Territorial e Geografia Agrária (GTGA/UNIR). E-mail: silvavv@gmail.com

\section{Wesley Henrique Garcia e SiLva}

Mestrando em Geografia (PPGG/UNIR). Graduado em Ciências Econômicas (Faculdades Alfredo Nasser). Membro do Laboratório Gestão do Território (Laget/UNIR) e pesquisador do Grupo de Pesquisa Gestão do Território e Geografia Agrária da Amazônia (GTGA/UNIR). E-mail: wesley.henrrique@hotmail.com 
1ª edição: dez. 2021

Fonte utilizada: Sabon

Formato: $16 \times 23 \mathrm{~cm}$ (Livro digital) Porto Velho - RO 


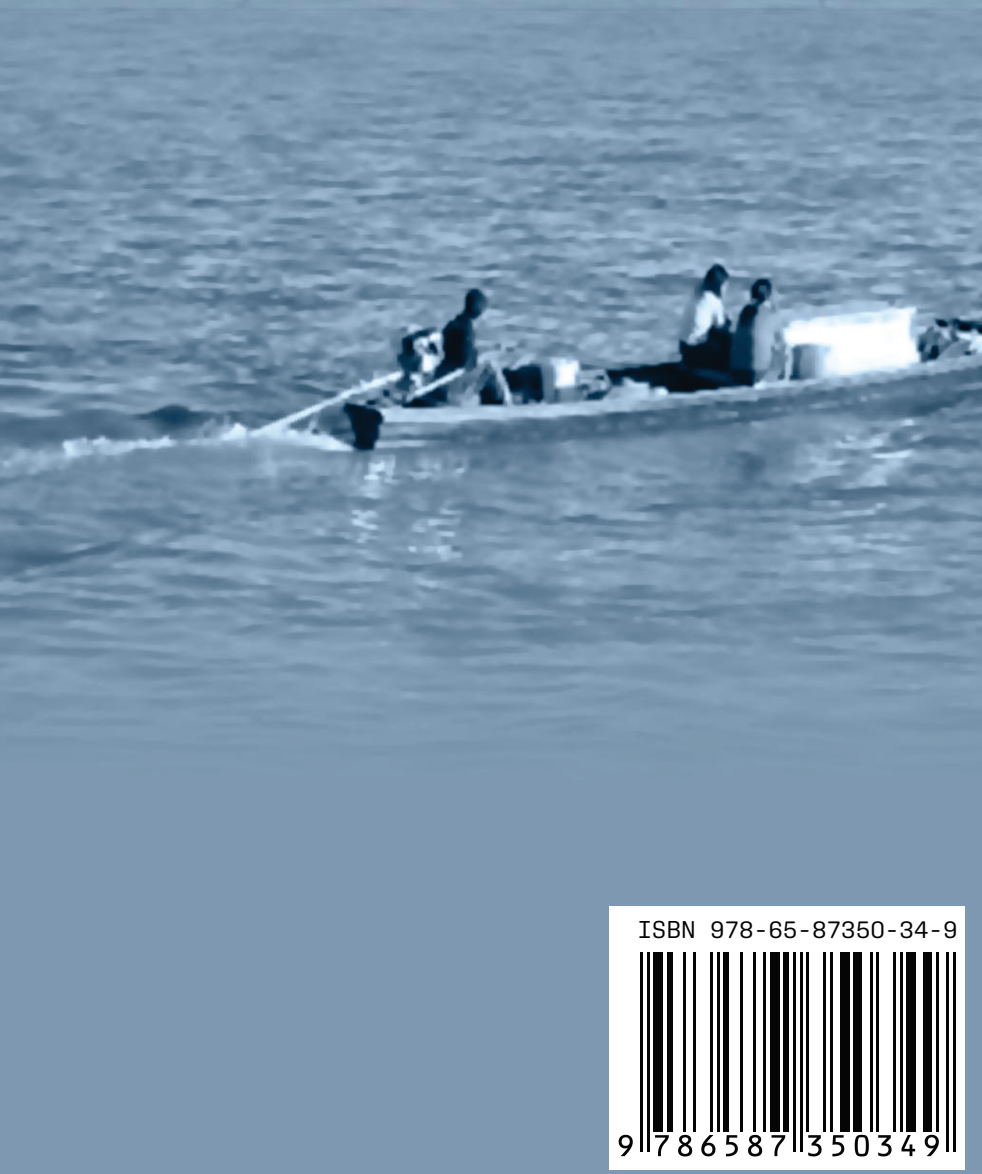

